\title{
Geology of the Renton,
}

Auburn, and Black

Diamond Quadrangles,

King County, Washington

GEOLOGIGAL SURVEY PROFESSIONAL PAPER 672

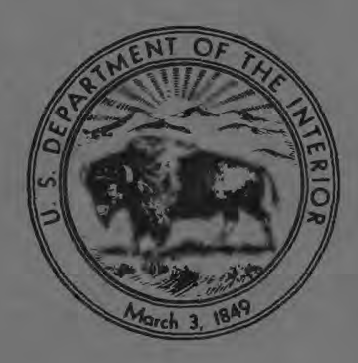




\section{Geology of the Renton,}

Auburn, and Black

Diamond Quadrangles,

King County, Washington

By DONAL R. MULLINEAUX

GEOLOGICAL SURVEY PROFESIONAL PAPER 672

A study of Cenozoic bedrock and

surficial deposits in the southeastern part

of the Puget Sound lowland

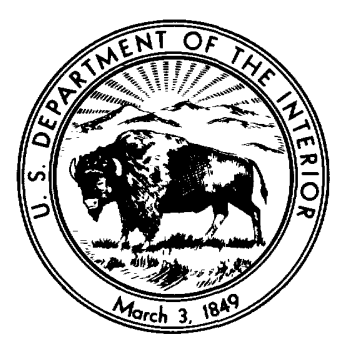

UNITED STATES GOVERNMENT PRINTING OFFICE, WASHINGTON : 1970 
UNITED STATES DEPARTMENT OF THE INTERIOR

WALTER J. HICKEL, Secretary

GEOLOGIGAL SURVEY

William T. Pecora, Director

Library of Congress catalog-card No. 78-607547

For sale by the Superintendent of Documents, U.S. Government Printing Office

Washington, D.C. 20402 - Price $\$ 1$. (paper cover) 


\section{CONTENTS}

Abstract

Introduction.

Location, purpose, and scope

Acknowledgments

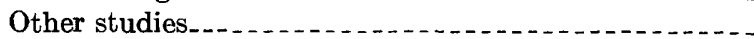

Geography

Topography and drainage

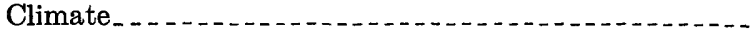

Vegetation.....

Culture.

Tertiary rocks

Lower Tertiary sedimentary rocks. .

Puget Group

Undifferentiated Puget Group near Black

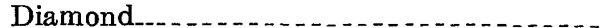

Tukwila Formation

Renton Formation........ 17

Environment of the Puget Group........ 19

Lincoln Creek(?) Formation _............... 19

Correlation of lower Tertiary formations......... 22

Intrusive rocks . _._.

Upper Tertiary rocks-Hammer Bluff Formation _.... 24

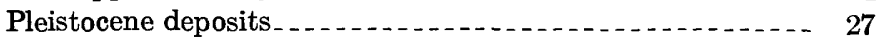

Sources of detrital material _.................... 27

Criteria used to establish stratigraphy ............. 29

Provenance.............................. 29

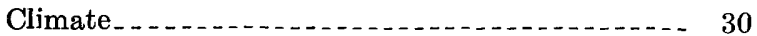

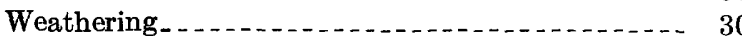

Stratigraphic sequence_.._.

Orting(?) Drift . .

Intermediate drift . . . .

Puyallup(?) Formation _................ 39

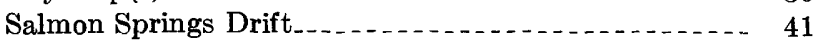

Undifferentiated drift in the Cedar River valley ..... 42

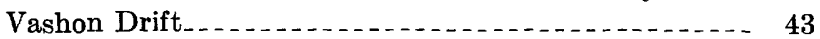

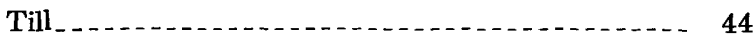

Topographic expression ... $\ldots \ldots \ldots 5$

Lithology .................. 45

Weathering ................ 45

Advance stratified drift_... $\ldots \ldots \ldots 6$

Recessional stratified drift. . . . . . . . . . . . . 46

Deposits of locally derived melt water. . . . 46

Deposits of the ice-marginal river......... 47

Age and correlation of Pleistocene deposits.........
Page Pnge

Postglacial deposits .

Lacustrine deposits.

Terrace alluvium .

Colluvium . . .

Osceola Mudflow .

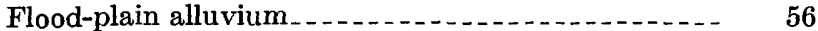

Cedar River valley...................... 57

Green River valley ..................... 57

White River valley . . . .

Duwamish Valley_........ 59

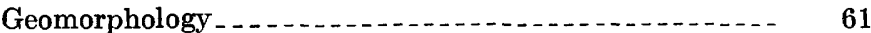

Origin of Duwamish Valley and adjacent drift plain. $\quad 62$

Development of the present drainage pattern....... $\quad 63$

Effects of the Vashon glacier.............. 64

Postglacial changes.......... 65

River characteristics.......................... 66

Green River.

White River

In Duwamish Valley ......... 68

Flood-plain development._._. 68

Structure _.

Lower Tertiary rocks_...

Upper Tertiary rocks..........

Pleistocene deposits........

Summary of geologic history . . .

Tertiary Period.

Quaternary Period................. 76

Economic geology

Engineering geology

Geologic conditions that influence land use Overconsolidation of fine-grained sediments_ $\quad 77$ Ground water........... 80

Heterogeneity of glacial till . . . . . .

Landslides. . . . . . . . . . . . . . . 81

Construction materials....... 82

Sand and gravel.

Stone

Silica sand....... 83

Oil and gas. . .

Clay

Coal $\ldots \ldots$

Peat and topsoil

References cited.... 86

Index 


\section{ILLUSTRATIONS}

Frgures 1-7. Maps:

1. Index of Washington

2. Index of recent geologic quadrangle mapping by the U.S. Geological Survey _...

3. Major physiographic elements in the southeastern part of the Puget Sound lowland . . . . ........

4. Principal physiographic units in the Renton, Auburn, Black Diamond, and Maple Valley quadrangles.

5. Changes of course and nomenclature of rivers

6. Pattern of drainage on drift plain

7. Principal populated areas and centers of communities referred to in text

8. Diagram showing generalized stratigraphic section of the Puget Group in the vicinity of Black Diamonc'...-

9. Graph showing cumulative curves of Puget Group arkose samples.

10. Chart showing late Eocene and early Oligocene fossil stages and zones.

11. Generalized column of stratigraphic sequence at Renton.

12. Chart showing generalized lithologic correlation of Eocene and lower Oligocene formations .

13. Diagram showing direction of movement of ice..

14. Stratigraphic sections of Orting(?) Drift .

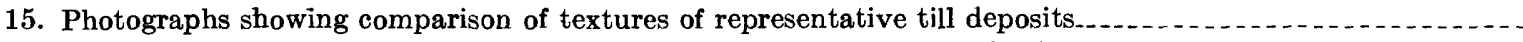

16. Graph showing cumulative particle-size distribution curves of glacial till 17-19. Stratigraphic sections:

17. Intermediate drift

18. Salmon Springs Drift

19. Undifferentiated drift

20. Map showing distribution of the Osceola Mudflow

21. Topographic map and section of upper part of postglacial fill

22. Map showing location of abandoned segments of preglacial courses of Cedar and Green Rivers and postglacial pre-Osceola course of White River

23. Generalized profiles of segments of the White, Green, and Cedar Rivers.

24. Map showing principal structural features in lower Tertiary rocks...

25. Summary of Tertiary stratigraphy and geologic history in the Puget Sound lowland southeast of Seattle...

Page

4

5

6

7

8

9

10

11

13

14

15

23

27

33

34

35

\section{TABLES}

TABle 1. Sequence of geologic-climate units recognized in the southeastern part of the Puget Sound lowland and the probable correlative geologic units exposed in the Renton, Auburn, and Black Diamond quadrangles......

2. Heavy-mineral suites in modern alluvium. . .

3. Heavy-mineral suites in Pleistocene sediments.

4. Mineralogy of silt and clay fraction of tills.

5. Summary of Quaternary stratigraphy.and geologic history in the Puget Sound lowland southeast of Seattle

6. Generalized description of engineering properties of principal mapped units in the Renton, Auburn, and Black Diamond quadrangles.
Page 


\title{
GEOLOGY OF THE RENTON, AUBURN, AND BLACK DIAMOND QUADRANGLES, KING COUNTY, WASHINGTON
}

\author{
By Donal R. Mullineaux
}

\begin{abstract}
The Renton, Auburn, and Black Diamond quadrangles lie southeast of Seattle, Wash., in the southeastern part of the Puget Sound lowland. Largely rural only a few years ago, this area is being increasingly used for suburban and urban development. These three mapped quadrangles are dominated physiographically by a broad drift plain of low relief, which stands several hundred feet above sea level. The drift plain consists chiefly of Pleistocene deposits that are overlain locally by thin postglacial sediments; it forms the ground surface in more than three-fourths of the mapped area. Steepsided valleys subdivide it into several segments and bound it on the west. The narrow valleys of the Cedar, Green, and White Rivers, three master streams that rise in the Cascade Range to the east, cut west and northwest across it to reach the broader Duwamish Valley that lies along the boundaries of the two western quadrangles. Postglacial alluvium on these valley floors forms the surface in about a fifth of the mapped area.

Exposures of pre-Quaternary rocks are few. Formations older than Tertiary are not known, and Tertiary rocks crop out only in very limited areas in the northwestern and southeastern parts of the area, near the cities of Renton and Black Diamond.

Tertiary rocks consist of sedimentary rocks of early Tertiary age, a few small bodies of intrusive andesite, and poorly indurated sedimentary rocks of late Tertiary age. Most of the lower Tertiary rocks belong to the Puget Group which, in the Puget Sound lowland, consists of a thick sequence of brackish- to fresh-water arkosic rocks that locally encloses a formation of andesitic sedimentary rocks. Near Black Diamond, the Puget Group is represented only by arkosic rocks, but they are at least 6,000 feet thick. The sequence in that area consists chiefly of sandstone and shale but also includes thin lavers of claystone and coal. The rocks in the lower part of the sequence are generally similar to those in the upper part, though minor differences are known; therefore, the Puget Group near Black Diamond is not subdivided into formations.
\end{abstract}

Near Renton, two formations of the Puget Group are recognized. The lower, more than 2,000 feet thick, is the Tukwila Formation. It consists mainly of sandstone, conglomerate, shale, and mudstone composed of fragments of volcanic rock, but it contains a middle member of arkosic sandstone and shale. The upper formation, about 2,500 feet thick, is the Renton Formation. The Renton consists of arkosic rocks much like the Puget Group rocks that are exposed near Black Diamond. Puget Group rocks of the Black Diamond and Renton districts are predominantly late Eocene in age.

The thick arkosic rocks of the Puget Group were laid down under generally uniform conditions over a wide, subsiding coastal plain by westerly flowing, continuously aggrading rivers. Subsidence was equaled by aggradation and the surface of the plain remained near sea level. Locally, volcanic activity resulted in construction of broad uplands of volcanic materials that stood above the surface of the arkosic plain; one such upland, represented by the Tukwila Formation, extended over the site of Renton. Cessation of volcanic activity, but continuation of both subsidence and arkosic aggradation, led to burial of the Tukwila by the Renton Formation. Beyond the limits of any of the volcanic uplands, as at the site of Black Diamond, arkosic sedimentation was continuous.

Near the end of Eocene time, arkosic sedimentation ceased, the mapped area subsided, and deposition of volcanic detritus derived from the east began. About 1,600 feet of the resulting Lincoln Creek(?) Formation is exposed at Renton. The Lincoln Creek(?) is dominated by volcanic sandstone and pebhle conglomerate partly cemented by calcite and zeolite. At Renton, the formation contains only minor amounts of finer grained marine rocks and no coal. These marine rocks may be late Eocene or early Oligocene in age, or both.

A few small bodies of intrusive andesite that have been mapped intruded the Puget Group and are therefore younger, but their age is not closely known.

By late Miocene time, the Lincoln Creek(?) and older ro?ks had been folded, raised above sea level, and eroded to a surface of low relief. In late Miocene time, thin continertal sediments of the Hammer Bluff Formation were laid down on this low-relief surface near Black Diamond. The lorer member of this formation is quartzose and kaolinitic and ras derived from the arkosic rocks of the Puget Group. The up ver member, however, consists chiefly of volcanic sandstone ind conglomerate derived from farther east. The Hammer Bluff also contains volcanic ash and pumice similar to the pumiceous detritus that is characteristic of several other Mioc?ne and Pliocene formations along both sides of the Cascade Range in Washington.

Repeated glaciation in the Puget Sound lowland during Pleistocene time is recorded by interbedding of glacial drift and nonglacial deposits; glacial deposits in the mapped quadrangles include drift sheets laid down during at least four major glaciations. Sediments of only one intervening interglaciation, however, were recognized. The Pleistocene glacial and interglacial formations of the mapped area are, from oldest to youngest, Orting(?) Drift, intermediate drift, Puyallup(?) Fornation (interglacial), Salmon Springs Drift, and Vashon Drift. Each of the drift sheets was deposited by a tongue, the Puget lobe, of a continental glacier that originated in British Columbia-the Puget lobe moved from there sorthward into and across the Puget sound lowland. The d-ift sheets of the Puget lobe are recognized as having a north?rn origin because of the suite of rocks and minerals they con- 
tain. A significant proportion of the rocks and minerals is typical of the mountains of British Columbia and northern Washington, but these rocks and minerals are sparse or absent from the parts of the Cascade Range drained by rivers that fiow into the mapped area. No till of Cascade alpine glaciers was identified in the three quadrangles. The climate of the interglaciation represented by the Puyallup(?) Formation, according to included pollen and diatom remains, became at least as warm as the climate is today.

The Orting(?) Drift consists mainly of gravel and sand, with intercalated stony till layers that record at least three advances of the ice across the outcrop sites. Almost all these sediments are stained brown, and montmorillonite is the predominant clay mineral in the till. No interglacial deposits were found directly above the Orting(?). Instead, it is directly overlain, with a sharp erosional unconformity, by intermediate drift, which is very different from the Orting(?) in lithologic character. The intermediate drift is composed predominantly of sand, silt, and clay rather than gravel and sand. It includes two extensive till members, which are composed almost completely of silt and clay-they contain few stones. Gray sediments are common though not predominant in the intermediate drift; and though montmorillonite is a major constituent of the tills, it is not as prevalent as in the Orting(?) Drift. The tills of the intermediate drift are similar to some glaciomarine "tills" and may have been deposited by ice that advanced into or even floated in proglacial lakes.

Locally, thin sediments of the Puyallup(?) Formation conformably overlie the intermediate drift; elsewhere they are disconformable. The Puyallup(?) sediments are characterized by reddish-gray volcanic sand probably derived from an ancestral Mount Rainier and also by volcanic ash and peat. In the mapped area they also contain at least one volcanic mudflow. The pollen and diatoms that are abundant in the peat and ash beds, respectively, indicate a deposition during a warm climatic interval.

The Salmon Springs Drift is composed of beds of sand and gravel that include interbeds of silt and clay, and of less extensive lenses or sheets of till that record at least two advances of the ice. It overlies the Puyallup(?) Formation with erosional disconformity. Locally, the mapped Salmon Springs includes gravel and sand derived from adjacent parts of the Cascade Range: this gravel and sand lies both below and above outwash and till of northern origin. The SaImon Springs Drift is several hundred feet thick along the Duwamish Valley in the Auburn quadrangle, yet it is less than 100 feet thick farther east-under the drift plain-along the Green and White Rivers. Sand and gravel in the formation typically is stained pale or yellowish brown; montmorillonite is an important clay mineral constituent, but it is not markedly less abundant in Salmon Springs till than in older tills of the intermediate drift, nor is it signiflcantly more abundant than in the younger Vashon till.

Along the Cedar River valley, a succession of strata, consisting of several layers of till and interbedded glacial and nonglacial sediments, reaches several hundred feet in thickness. Yet no distinctive drift formations or till members and no sediments derived from Mount Rainier were recognized. Peat layers occur at several stratigraphic horizons, but pollen from several layers that were sampled indicated only generally cool moist conditions and no warm period such as is represented by the Puyallup(?) Formation. Because of the absence of distinctive marker units and absence of evidence that any warm-climate periods separated the various glacial units, the sediments along the Cedar River were not subdivided.

Over most of the drift plain, either Vashon till or stratified drift covers the older Pleistocene formations. Till l'as at the surface on about half the drift plain and probably underlies most of the younger deposits that locally form th: surface. The till varies widely in thickness; it commonly is 10-20 feet thick, but locally it is as much as 70 feet thick. It consists of compact lodgment till-generally the hardpan of local usage -and looser ablation till. These materials constitute the ground moraine, which forms an irregular surface with a local relief of about 100-200 feet. Closed depressions in the ground moraine are common, and locally the moraine shows strong drumlinization in a south-southeast direction.

Vashon stratified deposits, chiefly recessional, cover broad plains, terraces, and channel fioors in the southeastern and central parts of the area, but farther northwest they occur only as small bodies along valleys. The more extensive deposits are products of a large melt-water river, composed of Puget lobe melt water and drainage from the Casce de Range, which flowed west and southwest across parts of the Black Diamond and Auburn quadrangles. The stratifled drift consists chiefly of loose friable gravel and sand.

Only the youngest drift of the Pleistocene sediments can be closely dated and correlated. Vashon Drift in tra mapped area, dated by radiocarbon methods, is between about 15,000 and 13,500 years old. It is correlative with part of the "classical" or later part of the Wisconsin drift of midwestorn United States. Older formations are not dated by radiometric methods, but some can be tentatively correlated with midwestern formations. The SaImon Springs Drift and the Plyallup(?) Formation probably are correlative with part of tl ? Wisconsin drift and with deposits of the Sangamon Interglaciation of the midwest, respectively. For the older drifts, no specific correlations are suggested.

Principal postglacial sediments are lacustrine denosits, terrace alluvium, colluvium, the Osceola Mudfiow, and modern flood-plain alluvium. Peat and other lacustrine sediments occur in small deposits on the drift plain and valley fioors. Colluvium, ranging from large landslide blocks to thin slope wash, covers much of the valley walls of minor streams, as well as valley walls of the Cedar, Green, and White Rivers. The Osceola, a bouldery montmorillonite-rich mulfiow that swept down the White River valley from Mount Rainier about 5,000 years ago, fiooded and now covers the toposraphically lower parts of the drift plain south of the Green Fiver. Modern flood-plain alluvium is thin in tributary valleys and is also thin in valleys of the major rivers where ther enter the mapped quadrangles. But lower in these valleys and in Duwamish Valley, the alluvium becomes progressively thicker and finer grained. In Duwamish Valley itself, postglacial alluvium is at least several hundred feet thick. Mnst of the upper 200-300 feet of that alluvium, and perhaps more, consists of detritus from Mount Rainier, deposited by the White River after the time of the Osceola Mudflow.

A thick, broad postglacial alluvial fill in Duwarish Valley shows that the Duwamish existed as a large valley at the time of the Vashon glacier retreat. Yet the possibility of its pre-Vashon existence, once generally accepted, is problematic. It is possible that the valley was formed before Vashon time, by either fluvial or glacial erosion, and that it was only modified by the Vashon ice, but it is also possible that it was formed entirely by ice scour during the Vashon Stade. In contrast, there seems no doubt that valleys of the Cedar and 
Green Rivers were cut in postglacial time, along consequent courses that were established on the drift plain during and shortly after ice retreat. The White also initially followed a consequent course over the drift plain in postglacial time, but it flowed south into the Puyallup River. The White entered the mapped quadrangles after the Osceola Mudflow, when the river established a course along the mudflow axis between the mountain front and Auburn. In its new position, it cut rapidly into the mudflow and drift plain, and became the principal supplier of sediment to the alluvial fill of the Duwamish Valley.

Though the White and Green Rivers are similar in size and formerly joined at Auburn, the White River has a notably steeper gradient and it carries a coarser and probably more abundant load. The white also swings fairly rapidly across its valley floor by migration of meanders, constantly reworking overbank deposits that have accumulated. As a consequence, its valley floor is covered mostly by channel deposits. The Green River, in contrast, migrates by meandering at a comparable rate only locally and within its own valley. Downstream, the Green migrates progressively less by meandering, and in the northern part of Duwamish Valley it shifts chiefly by avulsion. The Green does not rework the intervening overbank deposits as it shifts by avulsion and leaves the northern reaches of Duwamish Valley covered largely by overbank materials.

Structural features in the lower Tertiary bedrock include complex folds and faults produced before late Miocene time. Near Renton, many folds and faults are nearly alined with a regional west-northwest structural trend. Near Black Diamond, however, the major trend of folds is nearly north. Later widespread but relatively minor folding and faulting have affected upper Tertiary sediments and all but the youngest Pleistocene and Holocene sediments.

Of major economic importance in this area is the effect of geologic conditions on land use. The geologic deposits have highly diverse inherent engineering properties. Yet in a general way, values or ranges of values for some engineering properties can be correlated with individual geologic formations or with groups of them. Thus, engineering behavior of geologic units, to a certain extent, can be anticipated on the basis of identity of the units. Special conditions that involve factors other than inherent properties, such as landslides, are also highly relevant to land utilization.

Mineral resources that are exploited include construction sand and gravel, which is widespread, abundant, and in many places of good quality. Construction stone is valuable but scarce. Silica sand and clay are also mined, though in recent years production has not been large. Coal mining, formerly economically important here, has been suspended.

\section{INTRODUCTION}

\section{LOCATION, PURPOSE, AND SCOPE}

The Renton, Auburn, and Black Diamond $71 / 2^{-}$ minute quadrangles are in the southeastern part of the Puget Sound lowland of Washington, southeast of and adjacent to Seattle (figs. 1, 2). The northwesterm part of the Renton quadrangle is in the Seattle metropolitan area and only about 8 miles from Seattle's central business district. Southeastward, the Black
Diamond quadrangle reaches to within a few miles of the front of the Cascade Range (fig. 2). Except for a narrow strip in Pierce County along the south edge of the Auburn quadrangle, the entire mapped area is in King County (fig. 2).

These three quadrangles are part of a mapping project that encompasses eleven $71 / 2$-minute quadrangles (fig. 2). The purpose of the project is to provide geologic maps and other basic geologic data for an area of present and future urban and industrial use. The project area covers the southern part of Seattle and extends southeastward across the lowland into the foothills of the Cascades (fig. 2). Geologic maps have been published separately for several of the quadrangles: Buckley (Crandell and Gard, 1959); Poverty Bay, Des Moines, and Duwamish Head (Waldron, 1961, 1962, 1967) ; and Renton, Auburn, and Black Diamond (Mullineaux, 1965a, b, c). Final reports on the Lake Tapps 15-minute quadrangle (Crandell, 1963; Gard, 1968) include geologic maps of the Sumner, Buckley, Orting, and Wilkeson 71/2-minute quadrangles. In addition, a preliminary geologic map of S attle and vicinity has been compiled (Waldron and others, 1962).

Mapping of three quadrangles east of the Renton and Black Diamond quadrangles (fig. 2) by the U.S. Geological Survey as part of a cooperative project with the State of Washington provides additioral data on the lowland area. Results of that investiçation are contained in preliminary geologic maps (Vine, $1962 \mathrm{~b}$; Gower and Wanek, 1963) and in a final report by Vine (1969).

The Renton, Auburn, and Black Diamond quedrangles were mapped from 1954 to 1959 . Mapping was done on aerial photographs, and contacts were transferred planimetrically to a topographic base, with generally only minor adjustments to fit the topography as shown on that base. Along the valley walls, however, the match between aerial photographs and topographic base locally is poor. There, the altitudes of the nearly horizontal contacts between Pleistocene formations were measured by altimeter, and the contacts are shown on the map at the altitudes determined.

A report containing the geologic maps has previously been released in open file (Mullineaux, 1961), and the maps were published separately in 1965 (Mullineaux, 1965a, b, c). That report was rewritten in 1968 and some results of recent nearby investigations referred to, but no new fieldwork was done. Because the maps have been published separately, they are not included with this version of the report and can be obtained only as individual geologic quadrangle maps. 


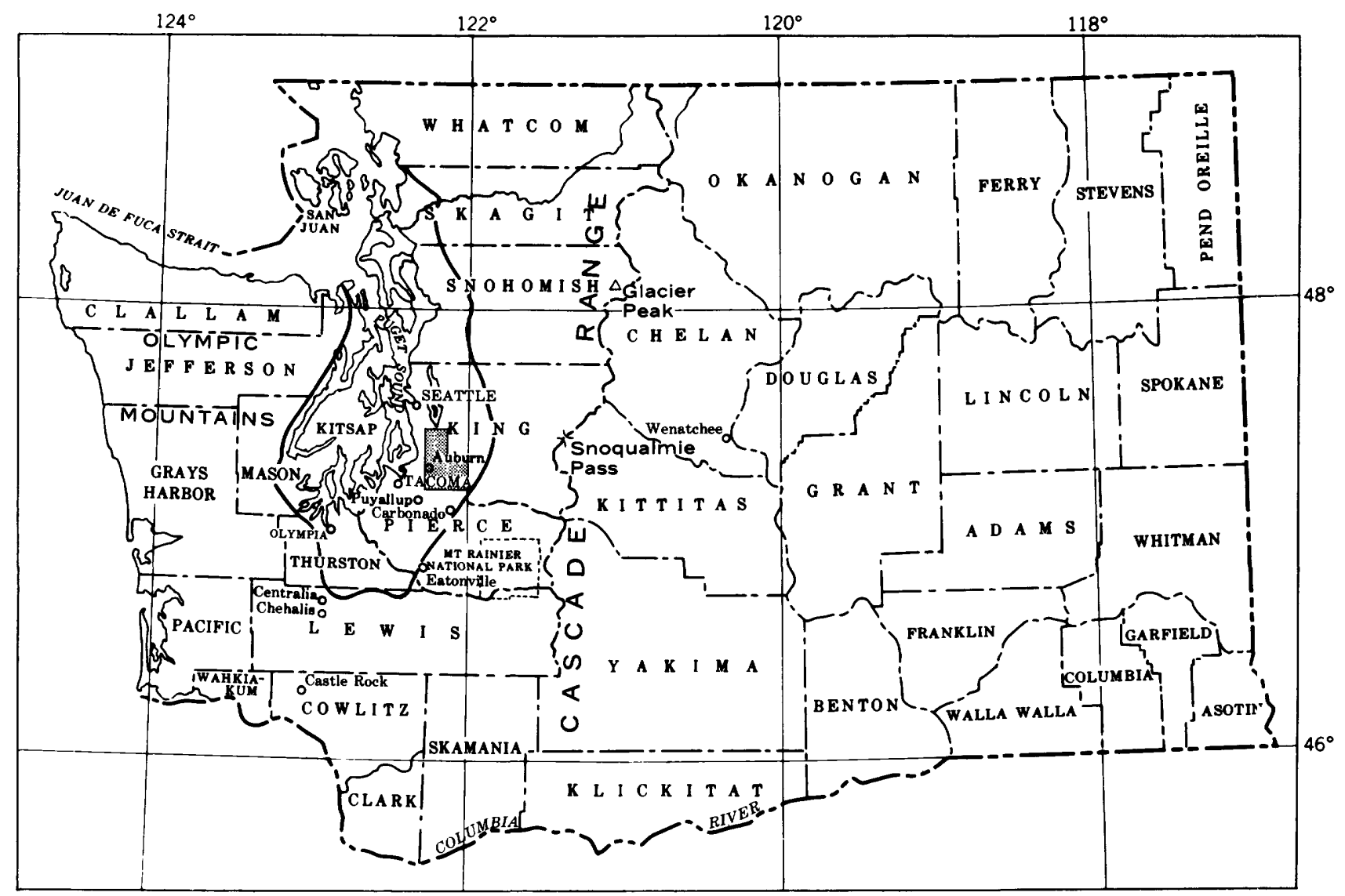

$\stackrel{50}{1} \quad 100$ MILES

Figure 1.-Index map of Washington showing the location of the Renton, Auburn, and Black Diamond quacrangles (shaded), and approximate boundary of Puget Sound lowland (heavy line). Modified from Crandell (1963, fig. 1).

\section{ACKNOWLEDGMENTS}

The author was assisted in the field at various times by L. A. Palmer, Herman Ponder, C. F. McKillop, D. A. Kapphahn, D. A. Holmes, and P. W. Birkeland, all of whom were geologic field assistants with the U.S. Geological Survey. The author acknowledges the help of the late Dr. George B. Rigg, Professor Emeritus, University of Washington, who provided unpublished information on peat bogs; Ralph Clark and M. Kochanik, International Pipe and Ceramics Corp., for information on characteristics of local clays; and S. L. Glover, former director, Washington State Division of Mines and Geology, for unpublished information on the Hammer Bluff Formation. The late R. W. Brown of the U.S. Geological Survey helped collect and identified the plant fossils. The molluscan fossils were identified by E. J. Moore and the Foraminifera by R. M. Todd, both of the U.S. Geological Survey. E. B. Leopold of the U.S. Geological Survey helped collect and analyzed samples for pollen and provided interpretation of climate during Ploistocene time. K. E. Lohman of the U.S. Geological Survey identified diatoms in samples submitted and also provided interpretations regarding the climate and physical environment in which they were deposited. Radiocarbon samples were analyzed in the U.S. Goological Survey radiocarbon laboratory under the direction of Meyer Rubin.

Sedimentary rock samples were analyzed for grain size and were prepared for heavy- and light-mineral studies in U.S. Geological Survey laboratorias under the direction of Dorothy Carroll, J. C. Hathaway, J. A. Sharps, and T. C. Nichols. In additior, identification of some heavy-mineral samples was carried out under the direction of Carroll and Hathaway. $\mathrm{X}$-ray analyses of clay and silt were made by and under the direction of T. C. Nichols, Julius Sshlocker, J. C. Hathaway, and L. G. Schultz of the U.S. Geological Survey.

The present study was at least partly concurrent with several other Geological Survey projects in ad- 


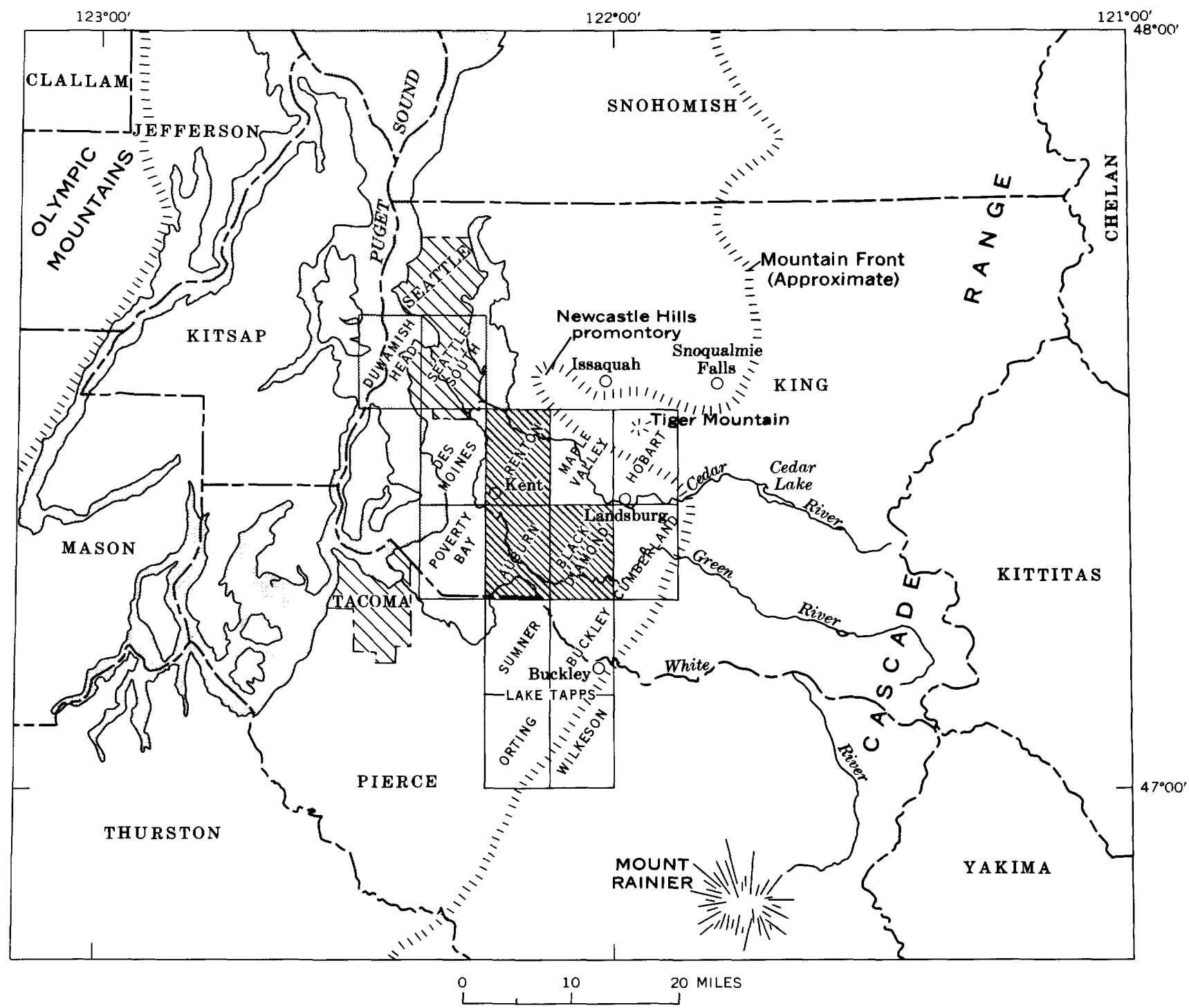

FIgure 2.- Index of recent geologic quadrangle mapping by the U.S. Geological Survey in the southeastern part of the Puget Sound lowland. The project of which this work is a part includes the Duwamish Head, Seattle South, D $: 9$ Moines, Poverty Bay, Renton, Auburn, Black Diamond, Sumner, Buckley, Orting, and Wilkeson 71/2-minute quadrangles. The last-named four compose the Lake Tapps 15-minute quadrangle. The Maple Valley, Hobart, and Cumberland quadrangles were mapped as part of another project, in cooperation with the State of Washington.

jacent areas, and the author has benefited greatly from information made available by the geologists responsible: D. R. Crandell, H. H. Waldron, L. M. Gard, Jr., J. D. Vine, H. D. Gower, A. A. Wanek, and J. E. Luzier. The late Dr. J. Hoover Mackin, formerly Professor at the University of Washington and the University of Texas, contributed significantly to the inrestigation through discussion, field conferences, and review of the text. Reviews of the text were also provided by Professors J. D. Barksdale, V. S. Mallory, and Peter Misch of the University of Washington, and by Crandell, Waldron, and Vine.

\section{OTHER STUDIES}

The discovery of coal near Renton shortly after 1850 and later at Black Diamond stimulated interest in the geology of the area, but most of the early reports and references to the coal and bedrock contained little discussion of areal geology. The first published results of areal geologic studies are those of Willis $(1886 ; 1898 \mathrm{a}, \mathrm{c})$ and Willis and Smith (1899); the stratigraphic divisions of bedrock and surficial deposits established in these reports have been followed since then with surprisingly little change. Willis' studies and those of White $(1888,1889)$ established 
the use, for example, of the name Puget Group for the arkosic nonmarine rocks in the Puget Sound lowland. Willis (1898c) also established the name Vashon Drift for the youngest drift sheet in the area, and recognized the future necessity of subdividing his preVashon drift unit.

Bedrock of this area has been discussed in many reports since the early reports of Willis. In 1912, Evans described in detail the bedrock and coal beds in King County and divided the rocks exposed along the Green River into three "series." Weaver (1916, 1937 ) published detailed descriptions of sections measured along the Green River during the study with Erans and further described the bedrock near Renton. Glover (1941) described previously unknown but economically important upper Tertiary clay and sand along the Green River, distinguishing them from the bedrock and less weathered Pleistocene deposits. In 1945, Warren, Norbisrath, Grivetti, and Brown published a detailed map of the bedrock and, locally, the depth to rock under the cover of drift. More recently, Gard (in Crandell and Gard, 1959; Gard, 1968) redescribed the bedrock in the area where Willis originally subdivided the Puget Group. Waldron (1962) and Vine (1962a), as a result of mapping west and east, respectively, of the Renton, Auburn, and Black Diamond quadrangles, defined and named lithologically distinguishable subdivisions of the Puget Group. Vine (1969) restudied the Puget rocks in the Maple Valley, Hobart, and Cumberland quadrangles (fig. 2) and with Gower and Wolfe (Wolfe, Gower, and Vine, 1961; Wolfe, 1968) established a stratigraphic column of Puget Group rocks based on floral zones.

Prior to this study, the Pleistocene deposits of the three quadrangles had not been mapped since Willis' time, though a soils map of King County by Poulson, Miller, Fowler, and Flannery (1952) shows the approximate outlines of some surficial geologic units, and many other studies in the lowland dealt in part with the area. Bretz (1913) made an extensive reconnaissance of glaciation in the Puget Sound lowland. His major contribution, the recessional history of the Vashon glacial episode, describes events near Renton and Auburn. Mackin (1941) studied the relation between continental and alpine glaciers along the west flank of the Cascades and described a major drainage diversion that brought great volumes of water across the Black Diamond and Auburn quadrangles. Later, Hansen and Mackin (1949) showed that there are at least two pre-Vashon drift sheets in the Puget Sound lowland and that the pollen content of sediments can be used to separate pre-Vashon drifts. In 1958, Crandell, Mullineaux, and Waldron established the se- quence of three pre-Vashon drift units that is used in this report, and, in 1963, Crandell published a comprehensive study of surficial geology and geomorphology in the Lake Tapps quadrangle to the south. Recently, the geologic maps of the Renton, Auburn, and Black Diamond quadrangles have been incorporated into a smaller scale geologic map and report that covers all of sonthwestern King County (Luzier, 1969).

\section{GEOGRAPHY}

\section{TOPOGRAPHY AND DRAINAGE}

The Renton, Auburn, and Black Diamond quadrangles lie in the broad lowland between the Olympic Mountains and the Cascade Range (fig. 2), where the terrain is dominated by a broad drift plain that stands several hundred feet above the floors of valleys cut into it. Though subdivided into many segments by troughs and valleys, this drift plain extends from the Olympics across the entire lowland to the Ciscades. Segments of it are the features called plateaus or islands by Willis (1898c) and later by Newcomb (1952), and Liesch, Price, and Walters (1963). In the vicinity of the mapped area, the drift plain is bounded on the north by a large bedrock ridge herein called the Newcastle Hills promontory (fig. 3), which

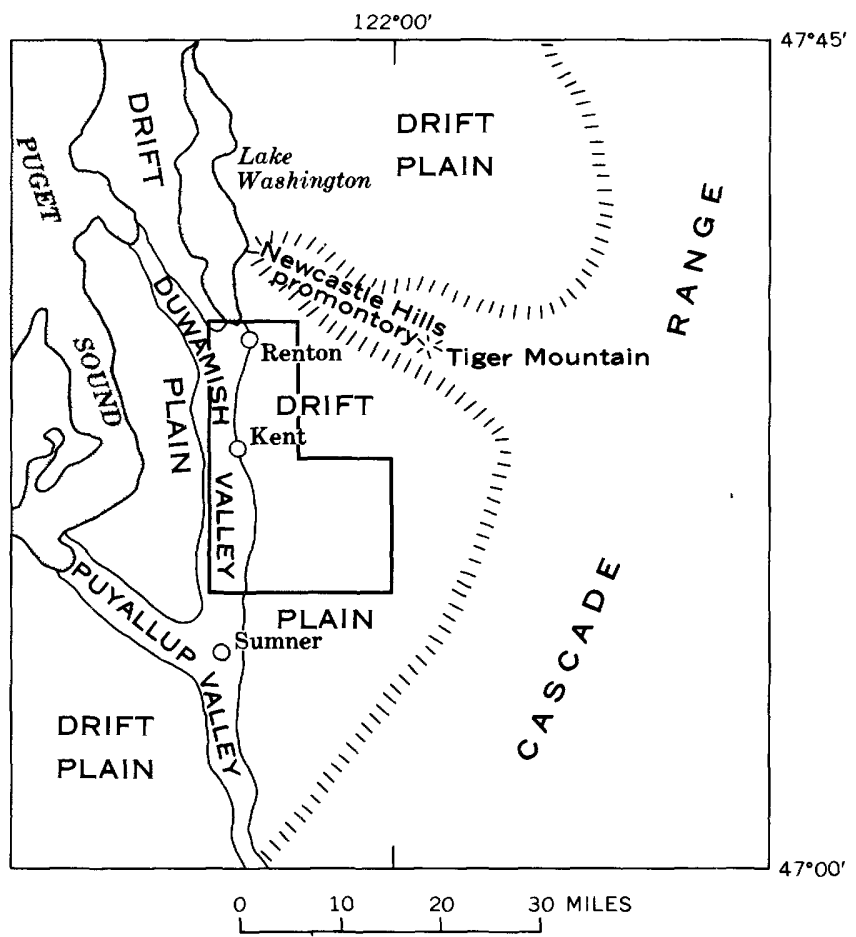

Figure 3.-Major physiographic elements in the southeastern part of the Puget Sound lowland (Renton-Auburn-Black Diamond area outlined), showing troughs and highlands that bound the drift plain of that area. 
is a northwest-trending highland that projects far out into the lowland from the Cascade Range. On the east and south, the drift plain is bordered by the southwest-trending front of the Cascades (fig. 3). It is separated from other parts of the drift plain farther west by the trough of the Duwamish Valley.

The drift plain constitutes about 80 percent of the mapped area; its surface is gently rolling, with a relief of 100-200 feet, and is underlain chiefly by ground moraine. The average altitude increases southeastward, from about 400 feet near the city of Renton to about 600 feet in the sontheast corner of the area. The highest point, in the sontheast corner of the Black Diamond quadrangle, is slightly more than 850 feet. Steepsided valleys of the Cedar, Green, and White Rivers subdivide the drift plain in this area, and the largest of the resulting segments is nearly bisected by a meltwater trench that will be termed the "Covington channel" (fig. 4). The drift plain between the Green and White River valleys is similar to that in other

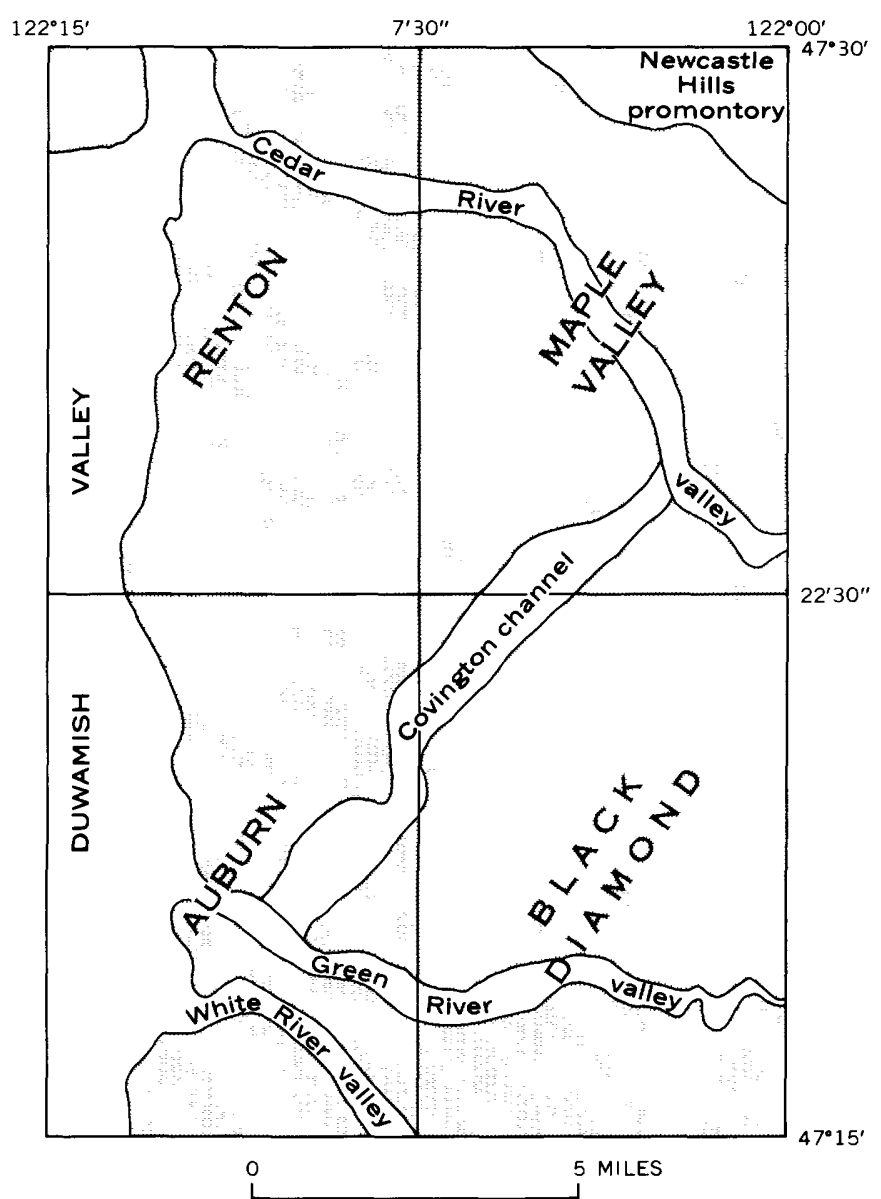

Figure 4.-Principal physiographic units in the Renton, Auburn, Black Diamond, and Maple Valkey quadrangles. Shaded area is drift plain. parts of the area, except that its lower parts have bren covered by the Osceola Mudflow, which forms a flattish surface that slopes gently northwestward.

The principal valleys that border and subdivide the drift plain locally are the Cedar, Green, and Wlite River valleys and the trough of the Duwamish Valley (fig. 4). The largest is the Duwamish Valley, which trends northward along the west side of the Renton and Auburn quadrangles. It is wide, about 2 miles across, and is characterized by gently sloping valley walls. This valley, or trough, is part of an extencive system of troughs in this part of the lowland. To the south, it merges with a similar trough that contcins the Puyallup River (fig. 3). To the north, it divides at Renton; one arm extends northwest to the Puget Sound at Seattle, and the other continues north, where it contains Lake Washington. These troughs are not valleys cut by postglacial rivers; instead they are former extensions of the Puget Sound waterway that have become partly filled to above sea level with lacustrine and alluvial deposits. The part of the trough system herein called the Duwamish Valley (after Willis, 1898c) was occasionally called the White River valley when the White River flowed nortl to Seattle before 1906, and was called the Green River valley after diversion of the White. But these terms involve a name change and also suggest that the wide trongh was cut by one or both of the rivers. The Duwamish Valley is herein regarded as extending from the junction with the Puyallup Valley at Sumner, north to Renton, and thence northwest to Seattle (fig. 3).

In contrast to the Duwamish Valley, the valleys of the Cedar, Green, and White Rivers, which have been cut in postglacial time, are narrow and steep walled.

The lowest altitude in the mapped area, about 10-15 feet above mean sea level, is on the Duwamish Valley floor west of Renton. From there, the altitude of the valley floor increases gradually southward to akout 100 feet at the mouth of the White River valley, then decreases southward. The valley floors of the Cedar, Green, and White Rivers rise somewhat more steeply and reach altitudes of more than 100,225 , and 275 feet, respectively, at the quadrangle boundaries.

The three master streams, the Cedar, Green, and White Rivers, all head in the Cascade Range and flow in well-defined valleys across the mapped area to the Duwamish Valley (figs. 2,4). Both the Cetar and the White Rivers form fans on the floor of the Dinwamish Valley and in the past have established north- and south-flowing distributaries on these fans. Within this century, the courses of both rivers have been shifted, that of the White River chiefly by natural change and that of the Cedar by artificial change. 
These drainage changes have been accompanied by several changes in the names applied to various parts of the river system in the Duwamish Valley in the last 60 years (Dart, 1952). Figure 5 shows the river system and the names applied in 1899, when the Tacoma 30-minute quadrangle map was published, and also the river system and the names applied in 1959. As of 1899, the main distributary of the White River flowed northward to join the Green River near $\mathrm{Au}$ burn and the Black River near Renton and to enter the Puget Sound at Seattle. A smaller distributary flowed southward to join the Puyallup River and enter the Puget Sound at Tacoma. The north-flowing distributary was known as the White River as far as its junction with the Black, and as the Duwamish River from the junction to the Sound. The smaller distributary was known as the Stuck River down to its junction with the Puyallup River. During a flood

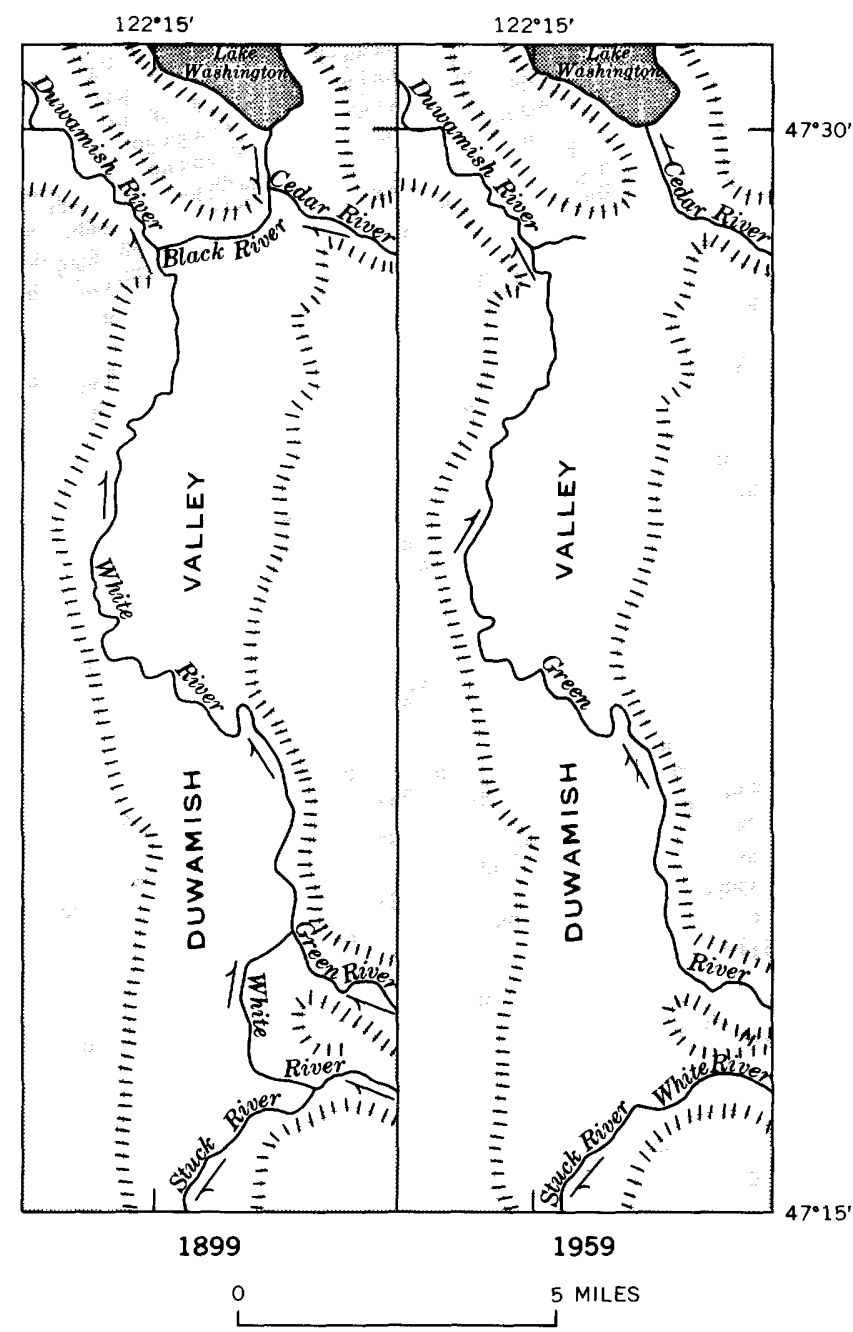

FigURE 5.-Changes of course and nomenelature of rivers in the Duwamish Valley, 1899-1959. in 1906, most of the White River discharge shifted southward and occupied the Stuck River channel. Shortly thereafter the White River was artificially confined to the Stuck channel, and only the Green River occupied the channel from Auburn north to the junction with the Black River.

The Cedar River has been prevented from joining the Green by way of the Black River since 1917, when a ship canal was dug connecting Lake Washington to Puget Sound. The lake was lowered several feet, the Cedar River was artificially directed into the lake, and the lake outflow was controlled by novigation locks. The Black River, which formerly contrined the discharge of both Lake Washington and Cedar River, was then reduced to a small brook. The name Duwamish is still usually applied to the river in the Duwamish Valley north of the former junction of the Green and Black Rivers, although the river is now merely the lower reach of the Green River.

In contrast to the master streams, most tributary streams head on the drift plain, where drsinage is only partly integrated. Lakes and bogs are abundant, and many smaller streams flow from swamp to swamp across the plain; only the larger streams-ind even those only near their mouths-have cut well-defined valleys. Northwest of the Covington channel, streams are controlled by a topographic alinement that trends slightly east of south, in the direction of last jce movement (fig. 6). As a result, many small streams that head just east of the Duwamish Valley do not flow westward into that valley, but instead flow southeastward. Big Soos Creek, for example, originates only a mile or two from the Duwamish Valley near Renton, then flows south-southeastward nearly parallol to the valley for about 8 miles, and enters the Covington channel leading to the Green River. Southeast of the Covington channel and north of the Green River, most streams flow in abandoned melt-water channels that lead westward and northwestward to the Covington channel or southward to the Green River valley (fig. 6 ). South of the Green, much of the flattisl surface of the Osceola Mudflow is artificially drsined by ditches. The largest stream, Newaukum Creak, flows northward across the mudflow to the Green River valley.

\section{CLIMATE}

The climate of the Puget Sound lowland is mild, with wet winters and dry summers. The mean annual temperature at Seattle and at Kent, in Diwamish Valley between Renton and Auburn, is about $52^{\circ} \mathrm{F}$ (U.S. Weather Bureau, 1961). The highest mean monthly temperature in Seattle, about $65^{\circ} \mathrm{F}$, occurs in July, and the lowest mean, about $40^{\circ} \mathrm{F}$, occurs in 


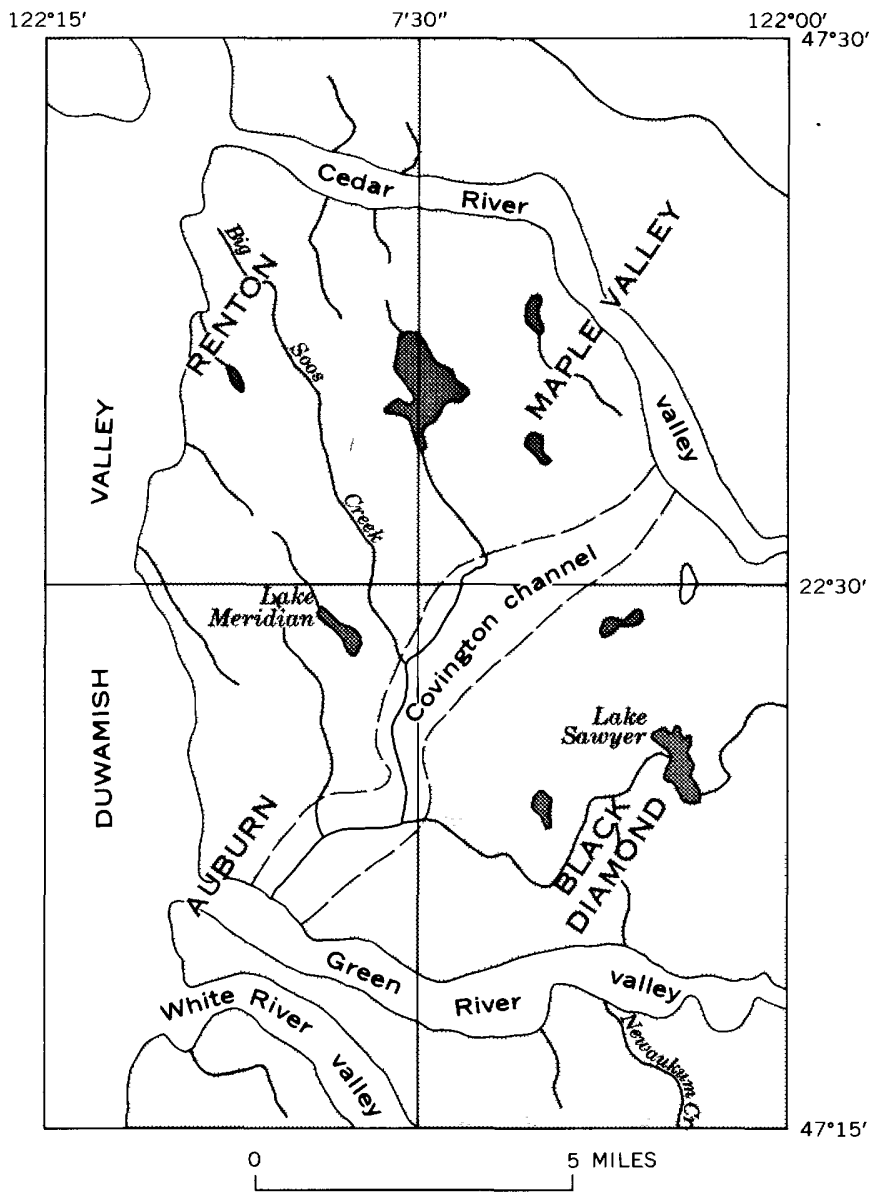

Figure 6.-Pattern of drainage on drift plain (shaded) in Renton, Auburn, and Black Diamond quadrangles, and in Maple Valley quadrangle southwest of Cedar River Valley.

January. Extreme annual temperatures are usually well within limits of $0^{\circ}$ and $100^{\circ} \mathrm{F}$.

Precipitation is concentrated in the winter months, and it increases from west to east across this part of the Puget Sound lowland. Seattle and Kent, which are typical of the western part of the mapped area, receive about $30-35$ inches of precipitation annually. Buckley, Snoqualmie Falls, and Landsburg, all of which lie along the east side of the lowland near the Cascade mountain front, receive about 50-60 inches; Cedar Lake, on the western slope of the Cascade Range, receives more than 100 inches annually. About 75 percent of the rainfall occurs in the 6 -month period from October through March; the peak rainfall is in December, when rainfall is frequent although usually not heavy.

\section{VEGETATION}

The mild and moist climate of the lowland results in a luxuriant growth of vegetation. The natural forest, which at one time consisted principally of large conifers (Hansen, 1947), has been logged off and only the second growth remains. The second growth is composed of closely spaced smaller trees, chiefly bigleaf maple, alder, Douglas-fir, lowland hemlock, and vine maple. A dense tangle of shrubs and smaller plants grows under the second-growth trees and on cutover land.

Plants grow virtually everywhere except on very rapidly eroded slopes, but the plant types differ markedly from place to place. These differences are strong? ${ }^{\text {? }} \mathrm{y}$ influenced by soil moisture, which in turn is influenced by the character of the underlying deposit. As a result, the distribution of certain plants locally indicates the identity and distribution of certain genlogic deposits. For example, large deciduous tress rarely grow on terraces of well-drained, gravelly g’acial outwash; stands of Douglas-fir and sparse underbrush characterize such deposits. In contrast, abundant deciduous trees and much brushy undergrowth cheracterize more clay-rich deposits such as glacial till. Few large trees of any kind grow on deep peat bogs; as a result, in wooded areas the bogs can be recognizad readily on the ground or on aerial photographs. On valley walls, plants that prefer very wet ground, such as devilsclub, skunkcabbage, and nettles, suggest the presence of springs or landslide deposits.

\section{CULTURE}

In 1960, most of the population of the area was in cities and towns in the Duwamish Valley, along the west edge of the area. Renton, the largest city, with about 18,500 people in 1960 , adjoins Seattle on the south. Kent, with about 9,000 people in 1960 , and Auburn, with about 12,000 , as well as several smallor cities, are situated farther south along the valley ( $\mathrm{f} g$. $\tau)$. The largest city east of the Duwamish Valley is Black Diamond, a former coal-mining center at the east edge of the Black Diamond quadrangle.

\section{TERTIARY ROCKS}

Tertiary rocks exposed in the Renton, Auburn, and Black Diamond quadrangles are the bedrock, which consists of sedimentary rocks of early Tertiary age and some intrusive rocks, and poorly indurated sedimentary rocks of late Tertiary age. Rocks older than Tertiary are not known in the mapped area; the nearest outcrops of pre-Tertiary rocks are in the Cascade Range about 20 miles east of Renton (Weaver, 193i). The lower Tertiary sedimentary rocks consist chiefly of the Puget Group of Eocene and Oligocene age, which is several thousand feet thick and which crops out in the northwestern and southeastern parts of the 


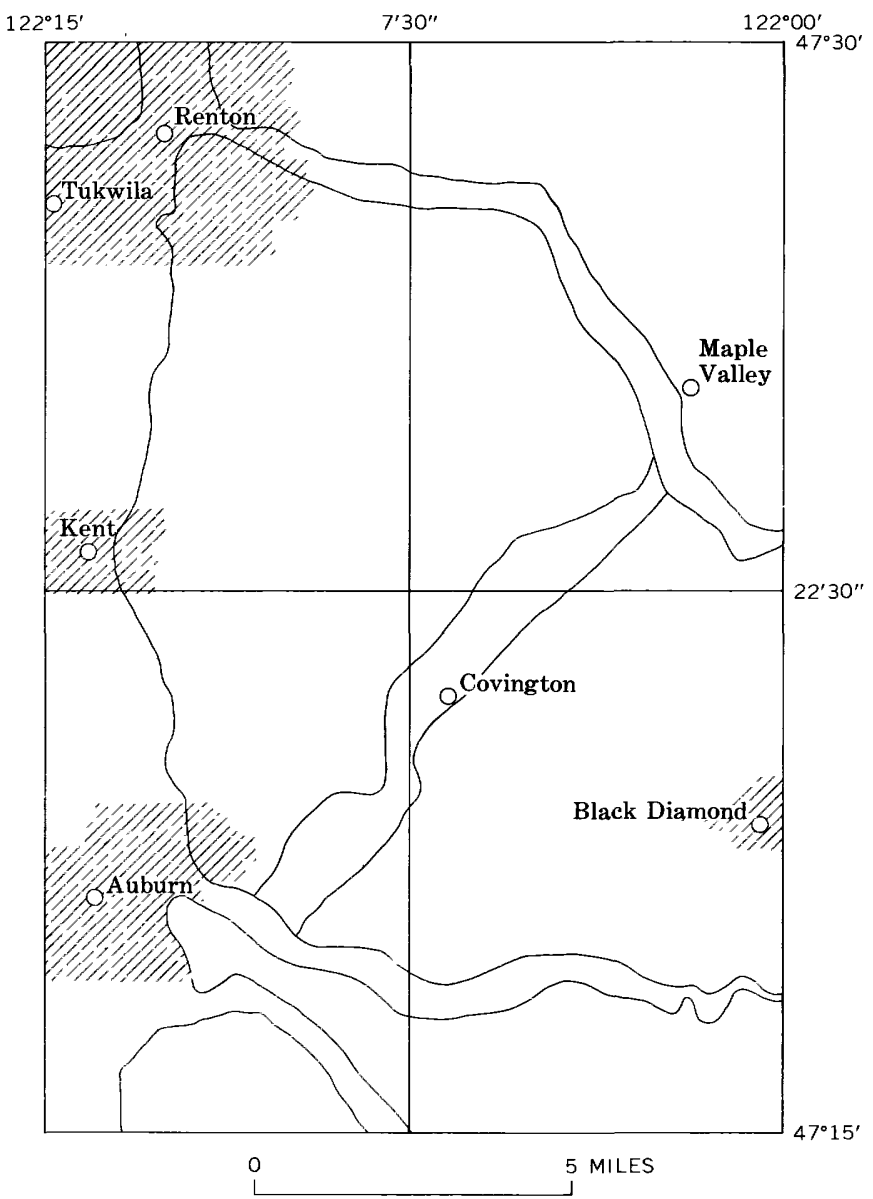

FIGURE 7.-Principal populated areas and centers of communities referred to in text.

area near the cities of Renton and Black Diamond (Mullineaux, 1965a, c). The Puget Group is overlain by the Lincoln Creek(?) Formation which is possibly of Eocene or Oligocene age or of both ages; this formation is more than 1,000 feet thick along the Cedar River east of Renton (Mullineaux, 1965a). South and west of Renton, the lower Tertiary rocks have been intruded by small bodies of andesite. The upper Tertiary rocks, the Hammer Bluff Formation, are but a few tens of feet thick and crop out only in a limited area along the Green River near Black Diamond (Mullineaux, 1965c).

\section{LOWER TERTIARY SEDIMENTARY ROCKS}

\section{PUGET GROUP}

The Puget Group in this area consists of a thick sequence of arkosic sandstone and interbedded shale and coal, which locally includes a formation of sedimentary rocks composed almost entirely of fragments of volcanic rock. The Puget probably underlies the entire area, but it crops out only in valley walls and in a few hills that stand above the surface of the drift plain.

Rocks of the Puget Group were first described by Willis (1886), who referred to them as th" "Coal measures of the Puget Sound basin." A study of molluscan fossils from these beds led White (1888) to conclude that although the rocks enclosing tl ? fossils were equivalent in age to the Laramie Frrmation, they had been deposited in a separate basin and deserved a different name. Accordingly, he proposed the name Puget Group (White, 1888, p. 446-447). Since then, the name Puget has been used consistently to refer to the coal-bearing brackish- and fresh-water arkosic sandstone and shale of Eocene and locally younger age in the Puget Sound lowland (Willis, 1898a; Landes, 1902; Smith, 1902; Evans. 1912; Weaver, 1916, 1937; Warren and others, 1945; Crandell and Gard, 1959; Waldron, 1962; Vine. 1962a). Most writers have followed White's usage of the name Puget Group, but some (Willis, 1898a ; Evans, 1912) have referred to these rocks as the Puget Formation and Puget Series.

Willis and Smith $(1899$, p. 8$)$ subdivided the Puget Group near Carbonado (in the Lake Tapps quadrangle) into three formations of arkosic rocks: the Carbonado (oldest): the Wilkeson, and the Burnett (youngest). Evans (1912, p. 42) subdivided the Puget near Black Diamond into three "series," all arkosic, that he called the Bayne (oldest), the Franl-lin, and the Kummer (youngest). These subdivisions were useful locally, but Willis and Evans (Willis, 1886, p. 759; Evans, 1912, p. 49) pointed out that, owing to such characteristics as the lack of marker hads, the similarity of strata from bottom to top, and the lenticular nature of the beds, projection of these subdivisions from one locality to another was not generally possible.

In some places, however, the Puget Group can be subdivided and correlated on the basis of lithology, because it contains a formation composed c'iefly of andesitic sedimentary rocks between the arkosic rocks. Such an andesitic formation lies within the Puget Group from west of Renton eastward to the Tiger Mountain area near Issaquah. In this region, the group has been subdivided into three formations. They are, from oldest to youngest, the Tiger Mountain Formation (Vine, 1962a), which is typically arkosic; the Tukwila Formation (Waldron, 1962), composed mostly of volcanic materials; and the Renton Formation (Waldron, 1962), composed of arkosic strata. The upper two of these formations crop out in the Renton quadrangle. The Tukwila Formation does not, extend southward to the exposures in the Black Diamond 
district, however, and in that area the arkosic Puget Group was not subdivided for mapping purposes. Because of the marked difference in the lithologic sequences that make up the Puget Group in the Black Diamond and Renton districts, the rocks in the two areas are described separately.

\section{UNDIFFERENTIATED PUGET GROUP NEAR BLACK DIAMOND}

Arkosic rocks of the Puget Group are well exposed in the canyon walls of the Green River in secs. 26, $2 \tau$, and 28 , T. 21 N., R. 6 E., and are sparsely exposed in the town of Black Diamond. Coal-mine maps show that these rocks are present also under a thin cover of Quaternary deposits throughout an area of several square miles near Black Diamond (Warren and others, $1945)$.

The exposures along the Green River extend northeastward into the Cumberland quadrangle for many miles (Gower and Wanek, 1963) ; these extensive outcrops provide one of the best exposed and most studied sequences of Puget Group rocks in this region. Willis (1886, p. 759) first reported the Puget Group of this area to be, not including the top or bottom beds, 6,200 8,200 feet thick; he later reported that measured sections in the area, though they did not represent the complete sequence, totaled 5,800 feet (Willis, $1898 \mathrm{~b}$, p. 5). Evans (1912, p. 42) and Weaver (1937, p. 5661) measured more than 8,300 feet of Puget Group rocks, and Warren, Norbisrath, Grivetti, and Brown (1945) reported the thickness to be at least 6,500 feet. This great variation in reported thickness probably arises from variations in tentative correlations across several anticlines and synclines as well as across covered zones. Vine (1969) recently restudied the section; he reported that though the measurements of Evans and Weaver were accurate for the upper part of the sequence, they were too great for the lower part. Vine estimated the total exposed thickness along the Green River near Black Diamond to be about 6,200 feet (fig. 8; Vine, 1969).

The thickest exposed sequence of the Puget Group within the mapped area, about 1,600 feet thick, crops out along the Green River from the east boundary of the Black Diamond quadrangle westward for 1-2 miles (Mullineaux, 1965c). These beds, which are exposed in the limbs of the Black Diamond anticline of Evans (1912), include parts of the Franklin and Kummer Series of Evans (1912; fig. 8, this report). The 1,600 feet that is exposed within the quadrangle, however, is a small part of the total thickness known in this particular locality. Nearly 1,300 feet of strata that are higher in the Kummer Series crop out between the quadrangle boundary and the axis of the Kummer syncline of Evans (1912) about half a mile farther east. In addition, drilling records suggest that at least 4,200 feet of older Puget rocks lie below those exposed

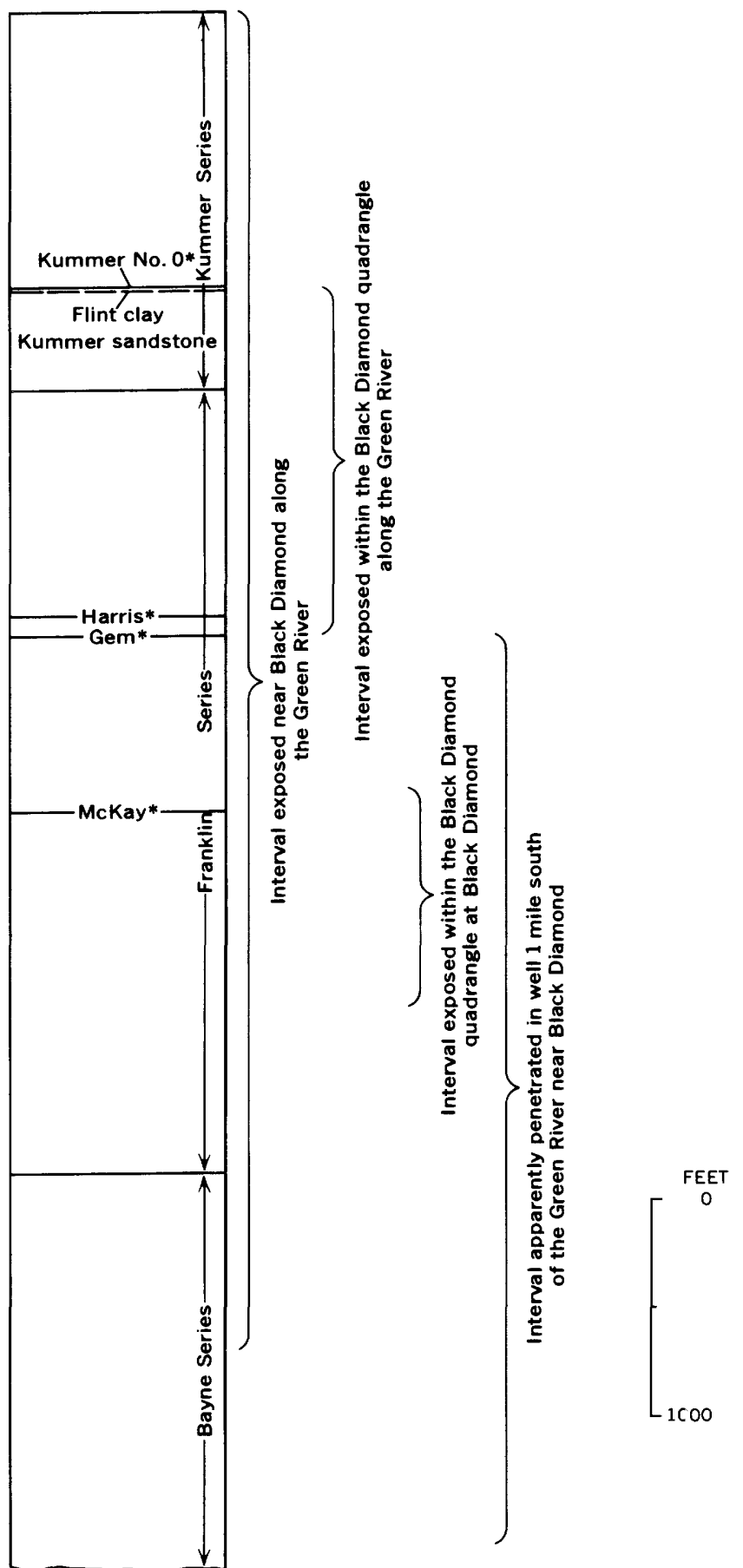

Frgure S.-Generalized stratigraphic section of the Prget Group in the vicinity of Black Diamond, showing app"oximate stratigraphic intervals exposed and penetrated by drilling, positions of the Bayne, Franklin, and Kummer Series of Evans (1912), and of several key strata. Data in part from Evans (1912), Anderson (1959), and $T^{\text {ine }}$ (1969). * indicates coal bed. 
in the Black Diamond anticline; one of several deep wells drilled near the crest of the anticline reached a depth of 6,023 feet in Puget Group strata that dip less than $45^{\circ}$ (Livingston, 1958; Anderson, 1959). The thickness suggested by drill records and exposures is thus about $\uparrow, 000$ feet, without the base of the group being reached.

In the part of the town of Black Diamond within the quadrangle, the Puget strata that are intermittently exposed represent a stratigraphic interval of about 1,000 feet of the Franklin Series that is stratigraphically lower than the rocks exposed along the Green River to the south (fig. 8). These older rocks. reach the surface in the town because the Black Diamond anticline rises north of the Green River. The anticline is also offset to the east; consequently, the Puget strata exposed at Black Diamond within the quadrangle are on the west limb of the anticline.

\section{LITHOLOGY}

Rocks in the Black Diamond district are mostly light-gray to light-brown sandstone and interbedded shale. The sandstone encloses at least one thin bed of granule conglomerate and an intraformational conglomerate. The latter is composed of shale fragments, ranging from pebble to boulder size, in a matrix of fine-grained sandstone and is exposed in the Green River valley at the east edge of the quadrangle. Highalumina claystone, the Kummer flint clay of Glover (1941), which is associated with coal and carbonaceous shale, lies a few feet below the intraformational conglomerate. Carbonaceous beds are numerous. More than 10 coal and carbonaceous shale zones, including the Gem, Harris, and Kummer No. 0 coal beds (fig. 8; Evans, 1912; Beikman and others, 1961, p. 52), are present in the strata exposed along the Green River within the quadrangle. At Black Diamond, strata that reach the surface include the McKay coal bed and another economic coal bed about 300 feet above the McKay (Evans, 1912, p. 151).

The sandstones are mostly medium to very fine grained. Coarser deposits are typically crossbedded, but bedding commonly is obscure except where it is accentuated by concentrations of carbonaceous material or iron oxide. Some fine-grained rocks are crossbedded; others are flat bedded. Sandstone samples analyzed for grain size range from well sorted to normally sorted in the terminology of Trask (1932, p. 72), with sorting coefficient values of about 2.1 to 3.5 . Trask's sorting coefficient is based on the central half of the particle-size distribution curve, and fairly well sorted sand grains represent that part of the curve for these rocks. All the samples of sandstones that were examined, however, contained 20 percent or more of silt and clay (fig. 9). Some other sorting valuas, such as those of Folk and Ward (1957), which are based on a larger portion of the distribution curve, take into account part of the silt and clay in these rocls. As a result, the sandstones are, in the terminology of Folk and Ward, poorly sorted to very poorly sorted. Individual sand grains in the Puget rocks are mostly subangular to subrounded, but every sample that we examined contained a few well-rounded grains.

Most of the sandstone is poorly cemented, micaceous, salt-and-pepper arkose, whose predominant minerals are quartz and feldspar. Judged from examinations of one thin section and stained grain mounts from seven samples, quartz constitutes about 50 percent of the grains; potassium feldspar, 20-35 percent; and plagioclase, 5-20 percent. In stratigraphically lower rocks of the Puget Group nearby, however, plagioclase is reported to be more abundant than potassium feldspar (Vine, 1969). Chert, quartzite, and other rock fragments make up less than 10 percent of the grains. Muscovite, biotite, and chlorite are distributed throughout the sandstones; the micas are conspicuous in hand specimens, yet they probably compose less than 5 percent of the grains. Suites of heavy minerals (specific gravity $>2.8$ ) generally are dominated by mica, opaque minerals, and brown, earthy aggregates that an X-ray diffraction analysis indicates are composed largely of kaolinite, siderite, and limonite (L. G. Schultz, oral commun., 1960). Other heavy minerals are sparse but consist of a wide variety of species; garnet and zircon are the most common, but tourmaline, staurolite, kyanite, rutile, pyroxene, and epidote are also common. In the Kummer Series along the Green River, just east of the quadrangle boundary, garnet is more abundant than zircon; ratios of garnet to zircon in three samples ranged from $2: 1$ to $5: 1$. Ratios of these two minerals in Kummer rocks reported by Bond (1959) are similar. In the Franklin Series within the quadrangle, in contrast, garnet is generally only about half as abundant as zircon.

Coarse and fine silt- and clay-size detritus (fig. 9), plus varying amounts of chemical cement, makes up the matrix of the sandstones. The principal clay minerals identified in the matrix of silty sandstone from the Kummer Series are kaolinite and smaller amounts of illite. Kaolinite and lesser amounts of mica (illite), mixed-layer minerals, and montmorillonite are reported to be the clay minerals typical of the upper part of the Puget Group farther east along the Green River (Vine, 1969). The cement is largely calcite. The calcite is widely but very unevenly distributed and typ- 


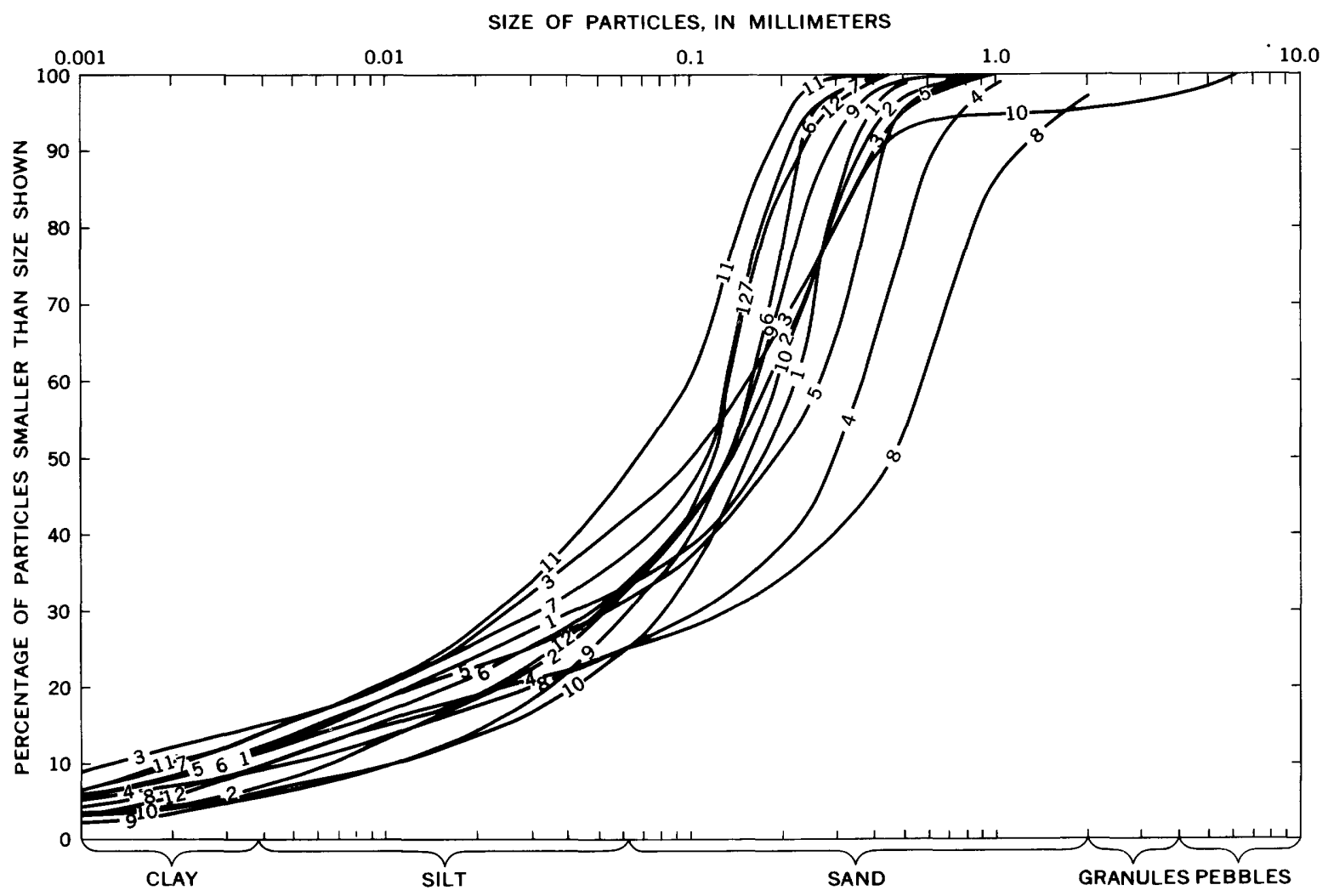

Frgure 9.-Cumulative curves of Puget Group arkose samples. Numbers 1- 8 are from the undifferentiated Puget Group in Black Diamond area. Numbers 9-12 are from the Renton Formation at Renton.

ically forms bulbous concretions or lenticular concretionary lenses. Locally, it composes as much as a third of the rock, not only filling intergranular spaces, but also replacing parts of grains along their margins.

Shale probably makes up less than a third of the Puget strata exposed in the quadrangle, forming less of the rocks in the upper part of the Puget Group along the Green River than it does in the lower part (Weaver, 1937; Vine, 1969). Siltstone is predominant over claystone, and both locally are carbonaceous. One of the claystones, the Kummer flint clay, is a highalumina deposit, containing as much as 51 percent $\mathrm{Al}_{2} \mathrm{O}_{3}$ (Glover, 1941) ; it consists mostly of kaolinite, gibbsite, and boehmite (Nichols, 1946).

\section{WEATHERING}

The Puget Group locally has undergone severe weathering. One locality of deep weathering is at Hammer Bluff, on the north side of the Green River in the NW $1 / 4$ sec. $28, T .21$ N., R. 6 E. In that area, arkose in the Puget is weathered and leached to a depth of as much as 30 feet and is now a light-gray friable sand composed mostly of quartz and kaolinitic clay. For an additional few tens of feet downward, in less weathered rocks, iron oxide has stained the ar- kose to brown or greenish-brown. Enough feldspar has been altered to clay and enough cement and iron oxide have been leached away so that the weathered arkose at Hammer Bluff has been used as a source of silica sand.

\section{Stratigraphic Relations}

The Puget Group is the oldest rock unit exposed in the Black Diamond district; it is overlain by andesitic sedimentary rocks of Oligocene age (Warren and others, 1945; Wolfe, Gower, and Vine, 1961). Neitlor the lower nor the upper contact of the group is expored in the mapped area; the approximate position of the upper contact is known just east of the Black Diamond quadrangle in the Kummer syncline, but it is hidc'en beneath a large landslide. The attitudes of the Puget Group and the andesitic sedimentary rocks indicate little if any angular unconformity between the $t^{-\top} 0$ formations. The andesitic sedimentary rocks are not exposed within the Black Diamond quadrangle; here, the Puget Group is unconformably overlain by the upper Miocene Hammer Bluff Formation.

Fossils AND AgE

Fossil leaves and fragments of petrified wood occur at many horizons in the Puget Group. According to 
Willis (1898a), the fossil flora represented was correlated by Newberry with that of the Laramie Formation, and the Puget was dated as Late Cretaceous or early Eocene. F. H. Knowlton (in Willis and Smith, 1899 , p. 3) noted that many species are represented and that there are well-marked differences between plants from the lower beds of the Puget and those from the upper beds at such places as the Kummer flint clay mine along the Green River. Willis (1898a, p. 403) stated that Knowlton, on the basis of a preliminary examination, reported the lower beds to be Eocene in age and the upper beds to be possibly younger than Eocene. As a result of a study of fossil leaves collected recently, Wolfe (in Wolfe, Gower, and Vine, 1961; Wolfe, 1968) recognized several biostratigraphic subdivisions in the Puget Group near Black Diamond. He (1968) assigned most of that part of the sequence exposed along the Green River within the Black Diamond quadrangle to the upper part of his Ravenian Stage, which he regards as of late Eocene age and approximately equivalent to the Tejon and lowermost part of the Keasey Stages of the standard Pacific Coast section (fig. 10; Weaver and others, 1944).
A few pelecypods have been recovered from the Puget in the Green River valley, mostly from or near the old Kummer clay mine, which is near the east edge of the Black Diamond quadrangle. The only fossils identified are a species of Corbicula, a genus reported to inhabit brackish and fresh water (White, 1889), and Butissa neuberryi White (F. S. McNeil, written commun., 1962), which also inhabits fresh water, and perhaps brackish water.

\section{SOURCE}

Angularity and abundance of quartz and feldspar grains as compared with lithic fragments are regarded as suggesting that the rocks of the Puget Group were derived chiefly from silicic, plutonic igneous, or metamorphic rocks (Pettijohn, 1957, p. 512). The few wellrounded sand-sized grains of quartz, garnet, and zircon indicate that a small part of the material was derived from preexisting sediments. An abunlance of feldspar grains indicates also that the source of the grains either was subject to a rigorous climate or had a high relief (Pettijohn, 1957, p. 328). F. H. Knowlton (in Willis and Smith, 1899, p. 3) pointed out that the climate in both eastern and western Washington

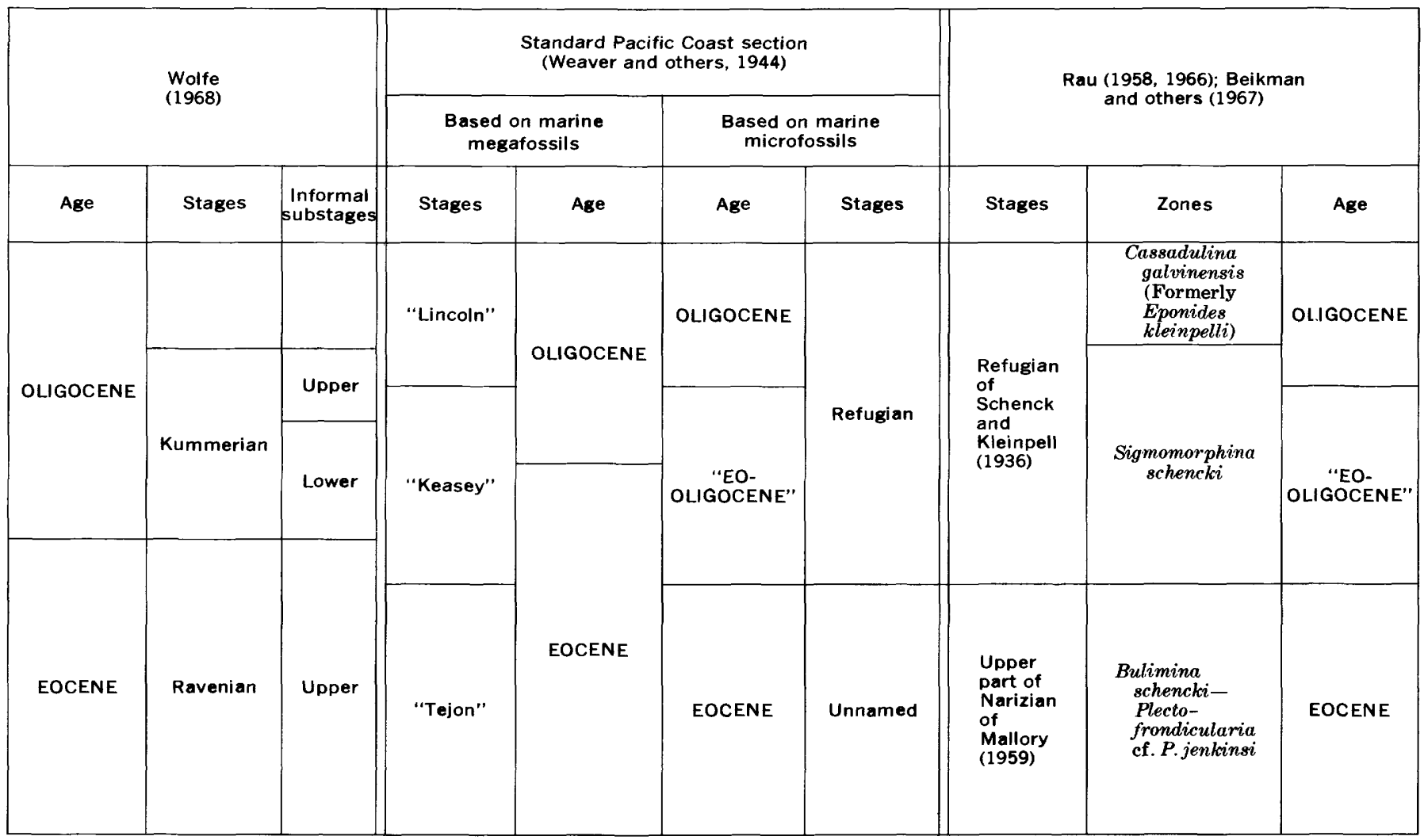

Figure 10.-Late Eocene and early oligocene fossil stages and zones, based on studies of plants by Wolfe (196?) and of Foraminifera by Rau (1966) and on correlations suggested by Wolfe and Rau with the standard Pacific Coast section. 
during Eocene time was mild; thus, high relief probably was the controlling factor.

Heavy-mineral suites show distinct changes from the lower to the upper parts of the Puget Group. Progressive upward change also occurs in types of clay minerals and feldspars present (Vine, 1969). Hence, the character or location of the source changed somewhat during deposition of the Puget rocks. Perhaps erosion uncovered different rock types in the same source area, or one or more streams from a different source entered the depositional basin.

Weaver $(1937$, p. 9, 67) suggested that the sources of the Puget Group lay generally east of the Puget Sound lowland in northeastern Washington, British Columbia, and Idaho. Bressler (1957), however, named the source of the Roslyn Formation, regarded by Weaver as an upstream equivalent of at least part of the Puget, as the Mount Stuart batholith of central Washington. The problem of source is complicated by the fact that not only the suggested source rocks, but also the probable sedimentary correlatives of the Puget Group and the Puget Group itself, show considerable variations in mineral content. There is general agreement that the Puget rocks were derived from somewhere to the east, but a specific source has not been located.

\section{TUKWILA FORMATION}

The Tukwila Formation, which underlies the Renton Formation in the Renton district, was named for the city of that name on the west side of the Duwamish Valley about 2 miles southwest of Renton (Waldron, 1962). The Tukwila crops out extensively in northwest Renton, and sparsely just south of the city. These rocks are part of the "tuffs and breccias" described by Warren, Norbisrath, Grivetti, and Brown (1945) as the "Eocene volcanic series," and have been described by other's (Willis and Smith, 1899; Weaver, 1937) to include andesitic flows, tuffs, breccias, and dikes.

The thickest section of the formation known in this district is in the hill in northwest Renton, where the rocks of the Tukwila Formation crop out intermittently along the strike of the beds for about a mile. Dips here range from slightly less than $20^{\circ}$ to about $40^{\circ}$; the exposed thickmess is inferred to be between 2,000 and 3,000 feet, and the total thickness is not known. The Tukwila Formation probably thickens toward the east; it is estimated to be nearly $\tau, 000$ feet thick about 10 miles east of Renton (Warren and others, 1945; Vine, 1969).

Three members can be distinguished in the Tukwila Formation in the Renton district (fig. 11) : a lower member composed chiefly of andesitic sedimentary rocks, which constitutes most of the formation; an

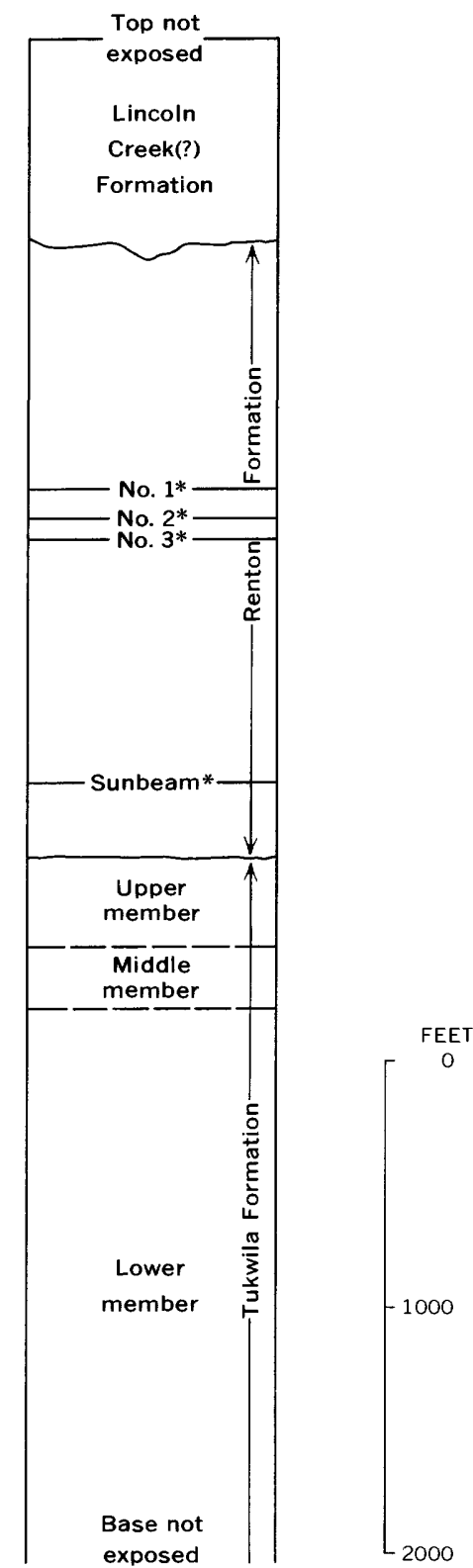

FIGURE 11.-Generalized column of stratigraphic sequence at Renton, and position of several coal beds (shown by*) in the Renton Formation. Iata in part from Evans (1912), Warren, Norbisrath, Grivetti, and Brown (1945), and Boikman, Gower, and Dana '(1961).

upper member of similar andesitic sedimentary rosks about 300-400 feet thick; and a middle member of arkosic sandstone, shale, and coal about 250 feet thick. The middle member is similar lithologically to the Renton Formation and will not be described separately.

LiTHOLOGX

The upper and lower members of the Tukvila Formation are composed chiefly of greenish-gray to brown sedimentary rocks that have a wide range in 
texture. Poorly sorted, locally conglomeratic and tuffaceous sandstone apparently is predominant, and conglomerate, mudstone, shale, and tuff are common. A boulder conglomerate that includes subangular as well as rounded fragments crops out in the middle of the upper member along State Highway 900 about a mile west of the center of Renton, and bouldery poorly sorted volcanic mudstones that probably are mudflows are exposed in both members. Small outcrops of lava occur in a few places in the Tukwila, but it is not evident whether these rocks are parts of flows or intrusions. Several beds of fine-grained silicified tuff lie about 500 feet below the top of the lower member. Coal is uncommon, although a layer of soft brown coal 1-2 feet thick was temporarily exposed in the upper part of the lower member west of Renton.

Most sandstones, conglomerates, and mudstones are poorly sorted and are poorly stratified or massive. Many of these rocks are intensely fractured in an irregular pattern. Only in the upper parts of the lower and upper members do normally sorted and clearly stratified sandstones seem to be common.

Boulders, cobbles, pebbles, and most sand grains of the upper and lower members are fragments of porphyritic andesite or basalt, and most other readily identifiable grains are plagioclase. Altered mafic minerals and opaque iron minerals are common, and quartz and apatite are accessory minerals. Nearly all the sandstone and conglomerate beds contain a considerable proportion of silt and clay, which consists chiefly of rock and plagioclase fragments in a matrix of green and brown minerals that include montmorillonite, zeolite, and iron oxides. Calcium montmorillonite is the dominant clay mineral in several mudstone samples analyzed by $\mathrm{X}$-ray diffraction. Yellowish-brown to dark-brown iron oxide is widely scattered throughout both the lower and the upper members. Organic material is common, as coatings on grains and as particles ranging from silt size to more than 6 inches in diameter. Most of the larger fragments of organic material are partly replaced by iron oxide and silica.

Tukwila rocks are mostly moderately to poorly indurated. Some, howerer, especially a few breccias and tuffs, are hard and resistant. Clay minerals, and perhaps iron oxide, apparently provide the coherence for most of the rocks, though chemical cement also is common. Calcite probably is the most abundant cement, although silica and zeolite may cement some rocks. Thin siliceous tuff beds probably are the hardest rocks in the formation. Along Highway 900 west of Renton, in the NIV1/4 sec. 13, the upper member of the Tukwila is cut by numerous reins composed chiefly of calcite and quartz. The reins are similar to those in an intrusive body that is exposed half a mile farther south, and they probably were deposited from solutions derived from the intrusive body.

\section{Aiteration}

Tukwila rocks are noticeably altered, as seen both in outcrop and under the microscope. Many exposures exhibit soft brown nearly unidentifiable rock in which structure and texture are obscure. Grains as well as matrix are strongly affected and are changed mostly to montmorillonite, calcite, chlorite, and zeolite. Alteration is relatively strong near the large intrusive body 2 miles west of the center of Renton, and it probably is due to hydrothermal action. In other places, surficial weathering has changed sandstone and conglomerate to clay in which little granular texture is retained. Most of this weathering probably occurred after deposition and deformation of the Puget Group. However, a buried weathering profile that formed at the top of the lower member cluring Tukwila time is exposed in Renton along Renton Aremue in the SW1/4 $\mathrm{NW}^{1} 1 / 4$ sec. 18. At this locality, hard and relatively unwerthered volcanic sandstone grades upward into softer deeply weathered sandstone in which the sedimentary texture is only faintly preserved and most grains are altered to clay. This weathered rolcanic sandstone is cverlain by and appears to grade upward into a gray kaolinitic claystone, which is overlain by coal at the base of the middle member. How the bed of kaolinitic claystone was formed is not clear. It could have been forned by weathering of the sandstone before deposition of the coal, but it could instead have been formed by in-place alteration beneath the coal or even simply by deposition of a bed of kaolinitic clay. If formed by woathering, a pause in deposition would be indicated that would be much longer than that shown by weathering of the still-recognizable volcanic sandstone, which in itself records a considerable pause in deposition during Tukwila time.

\section{Stratigraphic: Relations}

Neither the base of the Tukwila Formation nor the rocks directly underlying it are exposed in this area. At a locality 3 miles northwest of Renton, the Tukwila is in apparent fault contact with older marine sedimentary rocks (Waldron, 1962). About 10-15 miles east of Renton, near Tiger Mountain, the Tukwila conformably overlies and interfingers with the. Tiger Mountain Formation (Vine, 1962a). In northwest and south Renton the apparently conformable contact of the Tukwila with the overlying Renton Formation, 
though it is not exposed, can be located within a few feet.

The contact between the lower and middle members of the Tukwila Formation is exposed in Renton along Renton Arenue in sec. 18. The lower member here is strongly weathered, which indicates a time break between deposition of the two members; no evidence of erosion or angular unconformity, however, is exposed. The arkosic middle member contains volcanic rock fragments near its top, and its upper contact, which is not exposed, may be gradational.

Fossils AND AgE

Plant fragments were the only fossils found in the 'Tukwila Formation during this investigation. They occur throughout almost all the fine-grained andesitic sedimentary rocks and are especially abundant and well preserved in a zone about 200 feet thick in the upper part of the lower member. In 1958, these fossiliferous rocks were well exposed in many excavations in the NW1/4 NW1/4 sec. 13, T. 23 N., R. 4 E. Fossil leaves collected from the NW1/4 NW1/4 sec. 13 during this inrestigation were identified by $R$. W. Brown (written commun., 1957) of the U.S. Geological Survey as Lastrea fischeri Heer, Woodwardin sp., Equisetum sp., Smilax sp., Sabal sp., Carya or Aesculus sp., Tetracera sp., Plutunophyllum angustilobum (Lesquereux) MacGinitie, and Cercidiphyllum sp. The fossiliferous zone is exposed intermittently westward to the wall of the Duwamish Valley in the Des Moines quadrangle at the south boundary of sec. 11, T. 23 N., R. 4 E., where several fossil collections have been made at a site known as the Steels Crossing locality (F. H. Knowlton, in Willis and Smith, 1899). Fossil leaves collected by $\mathrm{H}$. H. Waldron at the Steels Crossing locality were also identified by R. W. Brown, who reported the following forms not found in sec. 13 (written commun., 1958) : Allantodiopsis erosa (Lesquereux) Knowlton and Maxon, Chaetoptelea sp., Platanus sp., Cinnamomum dilleri Knowlton, Castanea castaneaefolia (Unger) Knowton, and Alangium sp. According to Brown, the assemblage of leaves from this zone indicates that the enclosing rocks date from the latter half of the Eocene. J. A. Wolfe (written commun., 1964) stated that the assemblage from sec. 13 could represent either the lower or the upper part of the Ravenian Stage; both zones are regarded as late Eocene in age (fig. 10; Wolfe, 1968). The assemblage from Steels Crossing was assigned by Wolfe (written commun., 196t) to the lower part of the Ravenian. The Tukwila Formation of the Tiger Mountain area was assigned a late Eocene age by Vine (1962a) and a late Eocene and early Oligocene age by Wolfe (1968).
SOURCE

The coarse texture and volcanic detritus of the Tukwila Formation suggest that the formation was derived mostly from a nearby volcanic center. Typically poor sorting, angularity of even coarse detritus, and tuff beds as much as 2 feet thick also indicate that the source was not far distant. Interbedding of arkosic and rolcanic material in the formation suggests further that the lithologic character of detritus supplied to the depositing rivers changed rapidly. This and the evidence of contemporaneous volcanism indicate that newly erupted material rather than older volcenic rocks provided the volcanic detritus for the Tukvila Formation.

Evidence for location of the source of the Tukvrila comes largely from outside the mapped area. Warren, Norbisrath, Grivetti, and Brown (1945) conchuded that the source of rocks here described as Tukvila probably was near Issaquah, where the greatest thickness of the rocks was found. From there, the Tukvila thins southward and interfingers with arkosic rocks of the Puget Group (Warren and others, 1945; Vine, 1962 a). The volcanic formation is missing farther south in the Green River gorge, where volcanic detritus was found in only a few thin beds within the Puget Group (Vine, 1962a). Thinning of the formation toward Renton is probable but cannot be demonstrated, but the more abundant coarse breccias and lava flows near Issaquah Mountain indicate that the source was nearer that locality than it was to Renton.

\section{RENTON FORMATION}

The Renton Formation consists of the arkosic sandstone, shale, mudstone, and coal that make up the upper part of the Puget Group in the Renton district; the formation was named for the city of Renton by Waldron (1962). It crops out typically in valley walls in Renton in secs. 17, 18, and 19 and also crops out in sec. 30, 23, and 24 south and west of Renton. It has been regarded as part of the Puget Group since the Puget was first described by Willis (Willis, $189^{\circ} n$; Evans, 1912; Weaver, 1937; Warren and others, 194:5).

The thickness of the formation near Renton apparently is about 2,500 feet. Along the Cedar River, about 1,000 feet of the upper part of the formation overlies the Renton No. 1 coal bed (fig. 11). Along the Juwamish Valley wall, intermittent exposures indicate that the thickness under the same coal bed is about 1,500 feet. The Renton Formation in the Tiger Mountain area east of Renton is reported to be at least 2,250 feet thick (Vine, 1962a), and near Issaquah, northeast of Renton, it is $3,000-3,200$ feet thick (Warren and others, 1945). 


\section{LITHOLOGY}

The Renton Formation is composed mostly of arkosic sandstone and shale. In the upper third of the formation, probably a little more than half the rock is sandstone, but scattered exposures and one drill record suggest that the lower two-thirds is mainly fineand medium-grained sandstone. The formation also locally contains thin beds of sandy granule conglomerate and layers of mudstone. Several intraformational conglomerates, composed of fragments of shale in a sandstone matrix, are exposed in a commercial claypit in Renton on the south side of the Cedar River. Three coal beds that were mined for many years at Renton, known as the Renton No. 1, Renton No. 2, and Renton No. 3 (fig. 11; Evans, 1912, p. 110), lie just above the middle of the formation. Several other coal beds that have been mined occasionally, notably the Sunbeam bed (fig. 11; Warren and others, 1945), lie a short distance above the base of the formation. In addition, thin coal and carbonaceous shale beds are distributed throughout most of the formation.

The overall composition, grain size (fig. 9), structure, and texture of rocks of the Renton Formation are similar to those of the rocks of the undifferentiated Puget Group exposed in the Black Diamond district. The Renton Formation consists mainly of quartz and feldspar and contains virtually the same accessory minerals as the rocks in the Black Diamond district. However, plagioclase appears to be as abundant as potassium feldspar in the Renton Formation, garnet is the dominant nonmicaceous nonopaque heavy mineral in all samples examined, and siderite is much less abundant than in the undifferentiated Puget Group at Black Diamond. Kaolinite, mica (illite), montmorillonite, and chlorite are the most common clay minerals in the formation at Renton.

\section{Stratigraphig Relations}

The Renton Formation conformably overlies the Tukwila Formation and is overlain with at least minor disconformity by andesitic sedimentary rocks of the Lincoln Creek(?) Formation. About a mile east of the center of the city of Renton, the upper contact of the Renton Formation is exposed in a railroad cutbank on the south side of the Cedar River in the $\mathrm{SE} 1 / 4^{-}$ SE1/4 sec. 17 , and in a highway cutbank on the north side of the river in the $\mathrm{SW} 1 / 4 \mathrm{SW} 1 / 4$ sec. 16 . In the exposure along the railroad, the base of a volcanic conglomerate truncates bedding planes in the Renton at angles of $10^{\circ}-15^{\circ}$. This crosscutting relation apparently was interpreted by Warren, Norbisrath, Grivetti, and Brown (1945) as a slight angular unconformity. The relation is not clear because the attitude of the conglomerate is obscure, and because dips in the Renton and the overlying formation vary by several degrees even in single exposures. Overall, however, strata in the two formations appear to be parallel, and the contact probably represents a disconformity rather than an angular unconformity. Even the disconformity may be local, for the contact in the highway exposure on the north side of the river appears to be conformable.

Locally, arkosic strata crop out apparently stratigraphically above the upper contact of the Renton Formation. Along the railroad in sec. 17, a 3 n- to 40 foot-thick sequence of arkosic rocks crops out apparently more than 50 feet stratigraphically above the contact. Arkosic strata also occur in several smaller exposures above the contact. Stratification in the largest exposure is parallel to that in the Renton Formation, and the arkosic rocks at first appear to be an interbed in the overlying andesitic sedimentary rocks. The attitudes in most of these small exposures of arkosic rocks, however, differ markedly from the attitude in the Renton Formation, and in some erposures these arkosic rocks can be seen bounded by faults. Willis (1898a) described an exposure at this locality in which a sequence of thin-bedded sandstone with an attitude much different from that of Renton Formation strata was bounded on top and bottom b? faults. Furthermore, faults mapped in coal mines at Renton a mile to the west strike directly toward these outcrops (Evans, 1912). Although the arkosic strata alove the upper contact of the Renton Formation might be interbedded in the andesitic sedimentary formation, they presently are regarded as fault slices of Renton strata.

\section{FossiLs AND AGE}

No fossils were found in the Renton Formation near Renton, thus its age assignment depends on ages determined for underlying and overlying rocks. Plant fossils in the Tukwila Formation west of Renton are assigned to the late Eocene lower part of the Fiavenian Stage by J. A. Wolfe (written commun., 1964; fig. 10, this report). The few Foraminifera identified from the overlying Lincoln Creek(?) Formation at Renton do not distinguish between a late Eocene or early Oligocene age for the Lincoln Creek(?). A more definitive assemblage of forams from similar Lincoln Ceek(?) rocks about 5 miles to the northwest in Seattle, however, are assigned to the boundary-straddling "EoOligocene" age (W. W. Rau, written commun., 1967, H. H. Waldron, unpub. data, 1967). Therefore, the author regards the underlying Renton Formation at Renton as late Eocene in age as defined by forams. The formation is considered by Wolfe (1968), on the 
basis of plant fossils found east of the Renton quadrangle near Tiger Mountain to extend into the Oligocene.

\section{Source}

Composition and texture indicate that the Renton Formation, like the undifferentiated Puget Group in the Black Diamond district, was derived chiefly from silicic, plutonic igneous, or metamorphic rocks. The Renton probably was also derived from somewhere to the east. Small differences in composition between it and the rocks near Black Diamond may be owing to small lithologic differences within one large source area and to transportation to the two lowland districts by separate rivers.

\section{ENVIRONMENT OF THE PUGET GROUP}

The environment of deposition of the Puget Group has attracted special attention since the first studies of Willis (1886). The sequence of rocks is thick, it is rariable in detail but generally similar from bottom to top, and brackish- to fresh-water conditions were apparently maintained during deposition of the entire sequence. The studies of Willis $(1886,1898 \mathrm{a})$, White $(1888,1889)$, and Wearer $(1937,1945)$ produced a picture of a broad coastal plain representing a transitional environment reaching from wide valley floors on the east across coalescing deltas to an estuary or marine gulf on the west. Subsidence in this region was equaled by accumulation as conditions remained remarkably uniform. Subsidence was laterally unequal, however; thickness of sediments varied from place to place, and embayments were produced, including a marine embayment that extended several tens of miles eastward from Seattle. According to F. H. Knowlton (in Willis and Smith, 1899), the climate was warm and possibly subtropical during deposition of the lower sediments, and more temperate during deposition of the upper.

The arkosic sandstone and shale and the coal in the Puget Group in the mapped area appear to be wholly continental and typical products of fluctuating deltaic conditions as described by Willis, White, and Weaver. Marine fossils and other evidence of marine conditions, even deposits such as well-rounded sand that might represent beach environments, have not been found. Marine strata a few miles northwest of Renton, once thought to be interbedded with or correlative with the arkosic rocks near Renton (Weaver, 1916, p. 100), are now regarded as older and in fault contact with the Puget Group (Waldron, 1962).

The Tukwila Formation was deposited under conditions somewhat different than those under which arkosic Puget strata were deposited. The volcanic mate- rials, probably because of rapid accumulation, built broad uplands that rose above the aggradational lerel of the plain of arkosic sediments. On the uplands, slopes and stream gradients were steeper than those on the plain below. The upland areas were sites of deposition of coarse-grained mudflows and breccias, and fluvial sediments were poorly sorted as well as coarse grained. The land probably was significantly better drained, and coal swamps must have been uncommon. Building of these highlands, however, was not continuous. Overall subsidence continued during the pauses in accumulation of volcanic materials, and the flanks of the highlands were overlapped by continuously aggrading arkosic sediments. Renewed accumulation of volcanic materials again caused the highlands to be built out again over the arkosic materials at sites such as the Renton district. Then, eventual diminution or cessation of Tukwila volcanism allowed the Renton Formation to entirely bury the Tukwila in the Renton district. In contrast, the Black Diamond district lay between highlands of volcanic material and remained an arkosic plain.

\section{LINCOLN GREEK(?) FORMATION}

Marine and perhaps partly continental volcenic sandstone, conglomerate, mudstone, and shale overlie the Puget Group at Renton. These rocks are tentatively correlated with part of the Lincoln Formation of Weaver (1912), which has been redefined as the Lincoln Creek Formation of late Eocene to early Miocane age (Beikman and others, 1967). The rocks at Renton were previously mapped as part of an undifferentiated assemblage of Oligocene and Miocene beds (Warren and others, 1945). On the geologic map of the Renton quadrangle (Mullineaux, 1965a), they are shown as an unnamed formation of sedimentary rocks. Andesitic sedimentary rocks which are similar to those at Renton but somewhat coarser grained and which are apparently wholly nonmarine overlie the Puget Group south of Black Diamond in secs. 35 and 36, T. 21 N., R. 6 E., just east of the Black Diamond quadrangle boundary (Warren and others, 1945; Gower and Wanek, 196气).

The Lincoln Creek(?) Formation is exposed along the Cedar River in and east of Renton. North of the river, it crops out only in a roadcut that shows the basal contact. Along the south side of the river, however, it crops out nearly continuously from its basal contact eastward for about three-fourths of a mile, and in a small isolated exposure about a fourth of a mile farther upriver. From 1,000 to 1,100 feet of strata, largely sandstone and conglomerate that dip $20^{\circ}-30^{\circ}$ E., are exposed between the basal contact and a point 
half a mile farther east. There, steeply dipping beds that may be faulted break the continuity. From that point still farther east, 500-600 feet of strata, which consist mostly of mudstone and fine-grained sandstone that dip $20^{\circ}-10^{\circ} \mathrm{E}$., are well exposed. The rocks east of the steeply dipping beds are finer grained than the lower strata farther west, and they probably are not merely the lower beds repeated by faulting. Strata in the isolated exposure on the south side of the river, however, dip west, and their stratigraphic position is not known. On the assumption that there is no repetition by faulting in the east-dipping strata, the total thickness of the Lincoln Creek(?) exposed here is at least 1,600 feet.

\section{LITHOLOGY}

The Lincoln Creek(?) Formation is composed mostly of greenish-gray to brown sandstone. The lower 900 feet consists largely of coarse-grained conglomeratic sandstone. Pebble conglomerate constitutes the base of the formation, and conglomerate also prevails in a zone about 50 feet thick that is nearly $g(x)$ feet stratigraphically above the base. The upper $600-700$ feet of the exposed east-dipping strata is chiefly mudstone and shale alternating with beds of sandstone, but it also inchudes a small amount of conglomerate. Rocks in the isolated exposure on the south side of the river are chiefly sandstone and conglomerate.

Strata in the Lincoln Creek(?) are predominantly flat or plane bedded. In the lower part of the formation, stratification is usually obscure and the sandstones are thick bedded or massive. In the upper part, bedding typically is more distinct; the sandstone and shale are thick to thin bedded and are interlayered with mudstone. Lenticular bedding and cut-and-fill structure, however, are characteristic of the conglomeratic rocks. Both sandstones and conglomerates are poorly to normally sorted in the terminology of Trask (1932) and consist chiefly of rounded and subrounded clasts. No bouldery mudstones or strata characterized by angular fragments were seen in this formation.

Mafic volcanic rock fragments of sand and gravel size make up most of the formation. However, fragments of coal, shale, and arkose derived from the underlying Renton Formation are common in the lower part of the Lincoln Creek(?), and pebbles of lightgray vitric tuff are characteristic of the conglomerate about 900 feet above the base. Most pebbles consist of andesite or basalt in which plagioclase phenocrysts occur in a felted mass of tiny feldspar laths and either glass or alteration products. Volcanic glass in some pebbles apparently is fresh, but it is partly or wholly altered in most. Some pebbles are so altered that they consist only of a few feldspar phenocrysts set in a turbid matrix that consists chiefly of clay, iron oride, caleite, and zeolite. The only abundant grains other than rock fragments are plagioclase, which constitute as much as 20 percent of the grains in sandstones; quartz grains occur sparsely throughout the formation. Mafic minerals, including those as discrete grains and those in rock fragments, generally are altered beyond recognition. Heavy-mineral suites consist chiefly of opaque iron oxides, a few amphiboles and pyroxenes, and sparse apatite.

The matrix of these rocks consists chiefly of silt- and clay-sized fragments of feldspar, quartz, montmorillonite with some mixed layering, heulandite, cristobalite, amorphous material that includes iron oxide, and chemical cement. Chemical cement is more abundant than detrital silt and clay in some sandstones and conglomerates, and in one sample it makes up about 35 percent of the rock. Calcite is the dominant cement in the lower part of the formation; it not only fills interstices but also invades many grains. In the conglomerate near the middle of the sequence, however, zeolite cement is at places more common than calcite. Some beds are firmly cemented, but most are poorly cemented or friable.

\section{ALTERATION}

Most rocks in the Lincoln Creek(?) appear moderately weathered in outcrop and also show much alteration under the microscope. No gradational zones of any deep weathering profiles were recognizad, but a wide range of alteration is present from place to place. Some individual clasts are almost completely altered to iron oxide and clay minerals, others show only weathered rinds, and still others are glassy snd relatively unweathered. The most common alteration products seem to be montmorillonite and chlorite.

\section{STRATIGRAPHIC POSITION}

The basal contact of the Lincoln Creek(?) Formation is seen in two exposures. In one, the andesitic sedimentary rocks cut across bedding in the underlying Renton Formation, yet average dips and strikes in the two formations at this locality are approximately the same. The contact in that exposure apparently is disconformable, but not angularly discordant. In the other exposure, the basal contact appears to be conformable. It seems likely that the Lincoln Creek(?) conformably overlies the Renton except where it occupies channels cut into the underlying formetion. At Renton the outcrops of the Lincoln Creek(?) are overlain only by Quaternary deposits. A few miles northeast and northwest of Renton, however, sequences of 
chiefly Oligocene andesitic sedimentary rocks that overlie the Renton are several thousand feet thick (Weaver, 1937; Warren and others, 1945 ; H. H. Waldron, unpub. data, 1967). These sequences suggest that the part of the Lincoln Creek(?) exposed at Renton represents only the basal part of a thick section of Lincoln Creek (?) rocks that were once present in that general area.

$$
\text { FOSSILS AND AGE }
$$

Marine mollusks, Foraminifera, and fragments of fossil leaves have been collected about 1,000 feet above the base of the formation along the Cedar River about 200-400 feet east of the railroad bridge in the SE1/4SW1/4 sec. 16, T. 23 N., R. 5 E. The fossils are poorly preserved; only a few species of Foraminifera and one mollusk have been identified, and most of these identifications are tentative. The single mollusk was identified by E. J. Moore (written commun., 1959) of the U.S. Geological Survey as "Nuculana" sp. cf. " $N$." washingtonensis (Weaver). "N." washingtonensis (Weaver) generally is considered to be Oligocene in age (Durham, 1944 , p. 135 ; Weaver, 1942 , p. 38). However, Snavely, Brown, Roberts, and Rau (1958, p. 52) reported " $N$." washingtonensis (Weaver) n. subsp. in the lower part of the Lincoln Formation of Weaver in the Centralia-Chehalis district of Washington, where that part of the formation was assigned a late Eocene age.

The following Foraminifera from the Cedar River locality were identified by Ruth Todd of the U.S. Geological Survey (written commun., 1959) : Cyclammina pacifica Beck, Robulus sp. (rel. to $R$. inomatus), Plectofrondicularia sp. (rel. to $P$. miocenica and $P$. searsi), Nonion? sp. (rel. to N. soldanii), and Sigmomorphina sp. (rel. to $S$. jacksonensis). According to Miss Todd, these Foraminifera are marine, and the depth of water during deposition of the enclosing rocks was on the order of at least 100 fathoms. As the identifications are not certain, no definite age assignment can be made. If they could be confirmed, stratigraphic ranges reported elsewhere along the Pacific Coast for these fossils (Kleinpell, 1938, p. 221-222; Rau, 1958; Mallory, 1959 , p. 61, 89) would suggest that the Lincoln Creek(?) rocks near Renton are either late Eocene or early Oligocene in age or both.

Two assemblages of Foraminifera that are more varied and better preserved have been collected from the lower though not basal part of the Lincoln Creek(?) Formation in Seattle by H. H. Waldron. One has been assigned to either the Narizian Stage of Mallory (1959) or the Refugian Stage of Schenck and Kleinpell (1936), and the other to the lower Refugian
Sigmomorphina schencki zone of Rau (1958) (M. C. Israelsky, written commun., 1964; W. W. Rau, written commun., 1967 ; fig. 10, this report). These assemblages indicate that Lincoln Creek(?) deposition in the general area began during either late Eocene or Eocens to Oligocene time, as defined by studies of Foraminifera (fig. 10).

SOURGE

The volcanic rock fragments that compose mos $^{2}$, of the Lincoln Creek(?) prove that the formation was derived chiefly from a volcanic terrane. However, neither the Tukwila Formation nor other older volcanic rocks are thought to be the principal source. The lithologic change from the underlying arkosic Renton Jormation to andesitic sedimentary rocks is abrupt and suggests that the change was not due simply to gradual uncovering of volcanic rocks by erosion in the drainage basin. The change in lithology probably records eruption of abundant volcanic material in the source area of the Puget Group, or between that source area and the depositional basin. Eruptions could have produced such a change either by burying the rocks that yielded arkose or by overloading or blocking rivers that carried arkosic material.

Near Black Diamond, rocks that overlie the Puget Group are similar to the Lincoln Creek(?) at Renton but are coarser grained and continental. Farther east in the Cascades, correlative formations are largely flows, breccias, and tuffs. Thus the source volcanoes for the Lincoln Creek (?) probably were in the position of the present Cascade Range.

\section{ENVIRONMENT}

The Lincoln Creek(?) and correlative continental formations apparently were deposited in a marine gulf and on an adjacent coastal plain in a subsiding basin. Volcanic and andesitic sedimentary continental and marine formations of about the same stratigraphic position and age as the Lincoln Creek(?) are widespread along the west side of the Cascade Range (Warren and others, 1945; Snavely and others, 1958; Foberts, 1958; Fisher, 1961; Gard, 1968; Vine, 1969). At Renton, the Lincoln Creek(?) Formation seems to record at least two notable changes in environmont. First, transporting streams probably became either swifter or larger, bringing coarser detrital material into the basin. Second, the rate of subsidence incrersed enough to submerge the area near Renton despite the probably more rapid deposition. No coal was seer in the Lincoln Creek(?); any swamps that existed probably were ephemeral, and any peat that was formed probably was reworked by rapidly migrating streams. 


\section{CORRELATION OF LOWER TERTIARY FORMATIONS}

On the basis of the lithologic sequence, formations in the Renton district can be correlated with those in several other localities in and near the Puget Sound lowland (fig. 12). To the west and northwest, outcrops of the Tukwila and Renton Formations continue into the Des Moines and Seattle South quadrangles (Waldron, 1962; unpub. data, 196\%). The Seattle South quadrangle also contains a middle Eocene marine formation, as well as rocks assigned to lower and upper parts of the Lincoln Creek(?) Formation (Waldron, 1962; umpub. data, 1967). To the east, the Tukwila, Renton, and Lincoln Creek(?) Formations can be correlated readily with lithologically similar formations that crop out in the Newcastle Hills promontory near Tiger Mountain (Warren and others, 1945; Vine, 1962a); in that area the Tukwila is underlain conformably by the arkosic Tiger Mountain Formation, which is underlain in turn by the marine Raging River Formation of middle Eocene age (Vine, 1962a). There is little doubt of the lithologic correlation of rock units from one of these districts to the other, but the age of contacts may differ from place to place. For example, interpretation of Foraminifera in the Seattle-Renton area indicates that rocks overlying the Puget Group are as old as late Eocene, but fossil plants in the Tiger Mountain district suggest that the upper part of the Puget Group in that area is Oligocene in age (Wolfe and others, 1961; Vine, 1962a). Thus the upper contact of the Puget may be significantly time-transgressive in this area. However, the time difference may be only apparent, resulting from dating by marine Foraminifera at one place and by fossil plants at another.

The sequence of lithologic units of the Renton, Seattle, and Tiger Mountain area also correlates well with the rock sequence in the Carbonado district in the Lake Tapps quadrangle (Gard, 1968) farther south. The rock units in the Lake Tapps quadrangle differ somewhat in that the basal formation, the Carbonado, is arkosic and is middle(?) Eocene in age (Gard, 1968). Andesitic sedimentary rocks that overlie the Puget Group, the Ohanapecosh Formation, are also coarser and more angular than the Lincoln Creek(?) Formation at Renton. Like the andesitic sedimentary rocks near Black Dianıond, the Ohanapecosh at Carbonado is regarded as an onshore equivalent of the marine Lincoln Creek(?) rocks at Renton.

In the Black Diamond district between Renton and Carbonado, the Puget Group includes no mappable volcanic formation (Gower and Wanek, 1963; Vine, 1969). According to interpretations of fossil leaves (Wolfe and others, 1961), the arkosic Puget Group in the Black Diamond district spans the stratigraphic interval of the Tukwila Formation. Thus the Tukwila and Northcraft Formations probably were not coextensive but were derived from different sources.

Major Eocene and lower Oligocene formations in the Grays Harbor basin near Centralia (fig. 12; Snavely and others, 1958; Beikman and others, 1957) are also comparable in lithology to those in the Renton-Seattle area. Correlations are supported by the ages of the McIntosh, Skookumchuck, and Lincoln Creek(?).Formations that were determined fom marine Foraminifera (Rau, 1958). Comparisons made by means of Foraminifera content also allow the sequence near Centralia to be correlated with several other rock sequences in western Washington (Rau, 1958; Beikman and others, 196\%), but the other sequenes generally contain additional major rock formations.

Arkose similar to and correlated with tho Puget Group occurs at sereral other places in western and central Washington. East of the mapped area, the Roslyn and similar formations have been interpreted as upstream equivalents of the Puget Group (Weaver, 1937: Bressler, 1957). To the north, the Chuckanut Formation of McLellan (1927) was first regarded as part of the Puget (Willis, 1886), but now it is generally judged to be older than the Puget Group (Snavely and Wagner, 1963). To the west, in the Olympic Peninsula, rocks comparable in age to the Puget are not arkosic (Weaver, 1937; Brown and others, 1960). Sediments typical of the Puget, apparently did not extend west beyoud the position of the present lowland.

Deposition of arkosic sediments was extensive in western Washington during late Eocene time but was supplanted fairly abruptly by deposition of volcanic detritus and volcanic rocks. The change from arkosic to volcanic materials provides a widespread datum at the top of the Puget Group and correlative arkosic rocks. This change is dated by studies of Foraminifera as before the end of Eocene time in the Centralia, Castle Rock, and Seattle areas (Snavely and others, 1958; Roberts, 1958; H. H. Waldron, unpub. data, 1967), but by studies of plants as after the beginning of Oligocene time in the Tiger Mountain area (Wolfe and others, 1961; Vine, 1962a).

\section{INTRUSIVE ROCKS}

A few porphyritic andesite bodies crop out in the Puget Group in the northwestern part of the Renton quadrangle. The largest of these is extensively exposed in a large quarry in secs. 13 and 14, T. 23 N., R. 4 E., about 2 miles west of Renton. Its contacts are covered, 


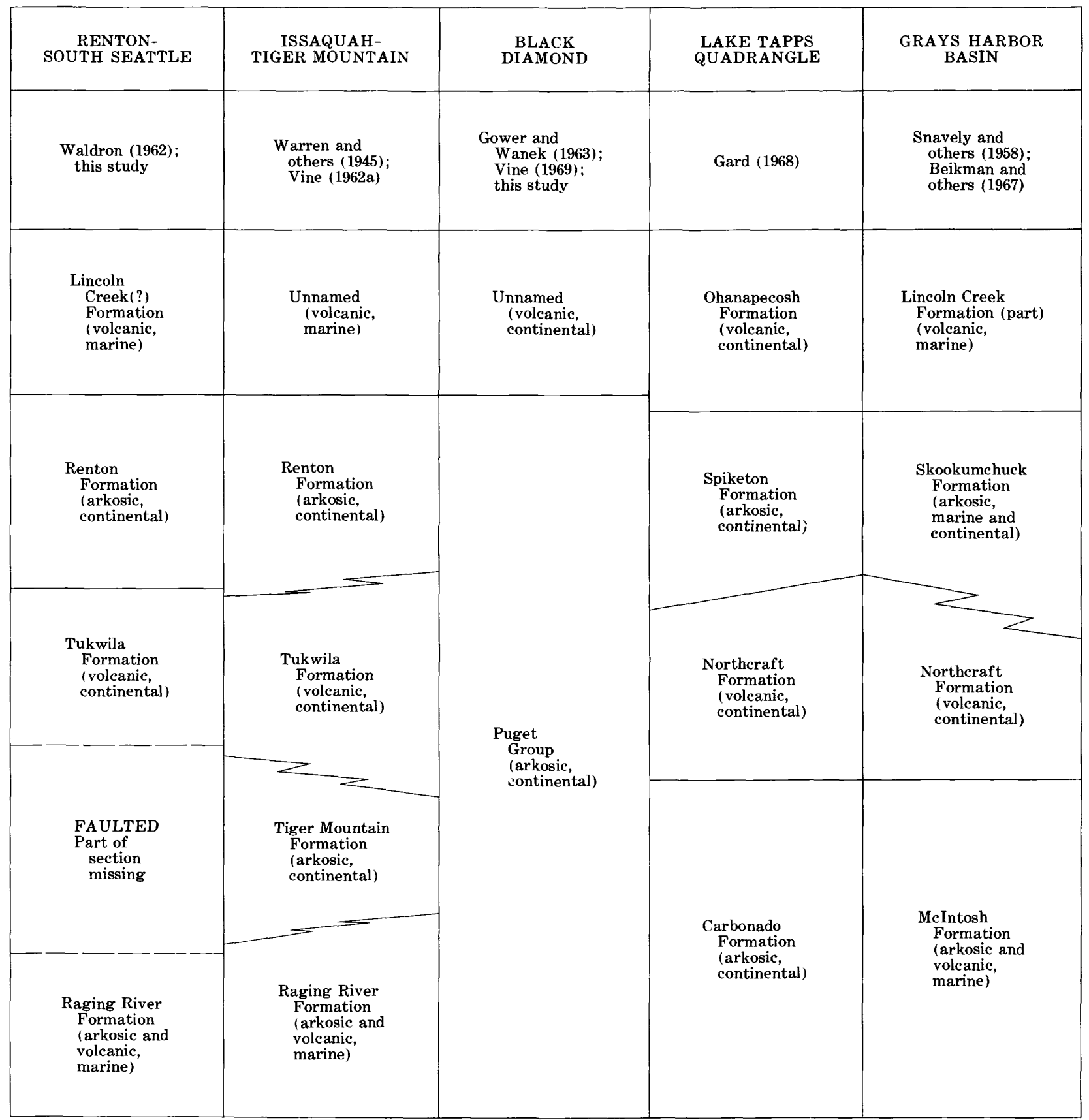

Figure 12.-Generalized lithologic correlation of Eocene and lower Oligocene formations in the Puget Sound lowland and adjacent areas. Age of contacts probably varies somewhat from place to place. Units termed "volcanic" include some which are composed chiefly of andesitic sedimentary rocks.

but the quarry shows a mass at least 1,000 feet long, 700 feet wide, and 150 feet thick. It is regarded as intrusive because no flow contacts, columnar joints, or vesicular zones have been found. Other probably intrusive rocks crop out in the city of Tukwila about a mile south of the large quarry, and about a mile south of Renton along the Duwamish Valley wall. A few smaller outcrops of similar rock were seen elsewhere within the Tukwila Formation but were not marned separately.

The quarry rock in secs. 13 and 14 is mostty gray, dense, and porphyritic, although it is altered to green and brown in bands and irregular patches and is cut by numerous greenish-gray and white veins. Conjugate joints several feet apart separate most of the body into large blocks. The rock consists of white to pale-g:een 
feldspar and dark greenish-gray mafic phenocrysts set in a medium-gray to greenish-gray dense groundmass. The feldspars, some of which are as long as $5 \mathrm{~mm}$, typically are strongly zoned and twinned andesine or labradorite. The mafic phenocrysts, some of which are as long as $\tau \mathrm{mm}$, are slightly to strongly altered. All appear to have been pyroxenes, with clinopyroxene more abundant than orthopyroxene. The groundmass consists of small feldspar crystals interspersed with pyroxene, opaque iron minerals, glass, calcite, and alteration products.

Both phenocrysts and groundmass are altered. The most common alteration product is a brown to brownish-green clay, identified as montmorillonite from X-ray diffraction pattems by .Julius Schlocker of the U.S. Geological Survey. It has replaced glass, mafic minerals, feldspar and, locally, the complete rock. The colors of the montmorillonite suggest that it is iron rich, but its index of refraction is lower than that of nontronite. Calcite and chlorite are also common in both phenocrysts and groundmass.

Montmorillonite, calcite, and quartz are common vein minerals. Veins of montmorillonite are as much as 6 inches wide in places, and reins of calcite and quartz are as wide as 8 inches. Pyrite is disseminated throughout the veins, and the presence of native copper was reported by the quarry operator.

A single sample of quarry rock that appeared representative was analyzed by rapid chemical methods, giving the following results:

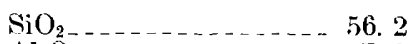

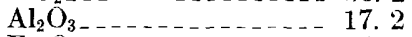

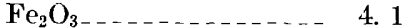

$\mathrm{FeO} \ldots \ldots . \ldots 3.6$

$\mathrm{MgO}$

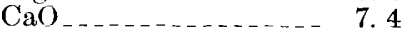

$\mathrm{Na}_{2} \mathrm{O}$

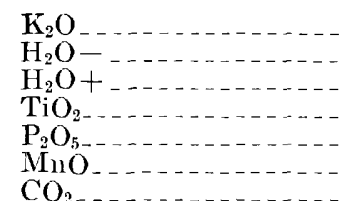

0.62

1. 4

1. 0

. 17

.19

10

The rock is classified as andesite according to silica content (Williams and others 1954) or according to a comparison of silica content with several other constituents (Rittmann, 1952). However, the rock locally is dark and frequently is called basalt for commercial purposes.

The andesite intrudes and is younger than the Eocene and Oligocene Puget Group but is overlain only by Pleistocene deposits. Presence of glass in the matrix suggests that the mass was intruded near the surface, but the shape of the mass is not known.

\section{UPPER TERTIARY ROCKS-HAMMER BLUFF FORMATION}

The Hammer Bluff Formation is the only upper Tertiary rock unit known in the mapped area. The Hammer Bluff was described and named by Glover (1936; 1941, p. $13 \uparrow, 144$ ) for a truncated spur on the north side of the Green River in the NE1/4 sec. 28, T. $21 \mathrm{~N}$, R. $6 \mathrm{E}$. Glover described the formation as ccroposed of quartzose sand and distinctive plastic buff-firing clay that were derived chiefly from arkosic sandstones of the Puget Group and that are characterized by woody lignite. Residually weathered arkose of the Puget Group at Hammer Bluff apparently has been considered part of the Hammer Bluff Formation in some reports, but it is not included in the formation as described herein. As used here, the Hammer Bluff contains two members: a lower member that mainly contains the clayey, quartzose sediments described by Glover, and an upper member that consists mostly of rolcanic sand and gravel.

The Hammer Bluff Formation crops out in streambanks and artificial excavations in the Green River valley in secs. $21,2 \tau$, and 28, T. 21 N., R. 6 E., in the southeastern part of the Black Diamond quadrangle. Exposures are few because colluvium covers much of the formation. The formation is well exposed in three places: on the south side of the river across from Hammer Bluff in the SE1/4 sec. 28, where it crops out in a meander scarp for about half a mile; on the north side of the river in commercial sandpits at Hammer Bluff; and in a meander scarp half a mile northeast of Hammer Bluff. The formation probably also underlies the wide undulating terrace on the north valley wall in secs. 21 and 28. Landslides that cover the nortl:western part of the terrace appear to be as much as several tens of feet thick, and the formation has not been mapped in that area; it has been mapped, hovever, in the sontheastern part of the terrace because prospect pits indicate in that part of the terrace the formation is within a few feet of the surface. Although the Hammer Bluff Formation is exposed intermittently along the valley for about 2 miles, the thickest observed stratigraphic section was across the river from Hammer Bluff, where it is only about 60 feet thick. Additional nearby exposures indicate that the formation is at least 100 feet thick.

\section{LITHOLOGY}

Both members are typically cohesive and compact, because they are clayey and have been compressed by thick Pleistocene sediments and ice, but they have not been consolidated into firm rock. The lower mamber is composed mostly of light-gray poorly sorted and poorly stratified clayey sand and sandy clay, which are at least 28 feet thick (Glover, 1941, p. 138). West and northwest of Hammer Bluff, however, it contains some fairly well sorted and stratified sand. The sind consists mostly of quartz, but it also contains feldspar, 
chert, and quartzite; some basalt fragments were reported in it by Glover $(1941$, p. 143$)$. The heavymineral suite of the lower member consists largely of epidote, zircon, garnet, tourmaline, amphiboles, and opaque iron oxide minerals. The clay minerals, as determined by $\mathrm{X}$-ray diffraction methods, are almost entirely kaolinite. Lignitic wood is distributed sparsely throughout the lower member except in one bed 2-3 feet thick, which consists mostly of flattened fragments of limbs and stems.

The upper member consists of brownish-green to brown sand, clay, and pebble gravel, some of which is crossbedded. Pebbles are mostly rounded porphyritic andesite or basalt, and sand grains are chiefly fragments of similar volcanic rock, quartz, and feldspar. About equal parts of kaolinite and montmorillonite are the only clay minerals identified in the single sample examined by $\mathrm{X}$-ray methods. Lignitic wood is distributed throughout and is abundant near the base. Some wood fragments are as large as 15 feet in length and $11 / 2$ feet in diameter. Light-gray pumiceous sand beds that are rich in green hormblende crop out in landslide blocks of the formation a mile northwest of Hammer Bluff, and rolcanic ash beds were reported in the formation by Glover (1941, p. 138).

\section{WEATHERING}

The Hammer Bluff Formation is conspicuously weathered. The quartz sand and kaolinitic clay in the lower member probably are products of weathering of Puget Group arkose. Much of that weathering, however, presumably occurred in place within the Puget rocks, and still more weathering might have occurred during transportation. How much weathering took place after deposition of the materials in the Hammer Blutf Formation is not known. The upper member, however, clearly has been weathered in place, for most constituent rock fragments are now soft and altered partly to clay. About 60 percent of the pebbles in one pebbly sand exposed in the commercial sandpit at Hammer Bluff are weathered enough to be broken by a gentle blow of a hammer. In some sand layers in the upper member, sand grains are soft, "greasy," and altered almost completely to clay, even though the texture of sand is retained.

\section{STRATIGRAPHIC RELATIONS}

The Hammer Bluff Formation is underlain by the Puget Group and is orerlain by Pleistocene sediments. Both contacts are angular unconformities. In 1960, both were exposed in the commercial sandpit at Hammer Bluff and in a meander scarp to the south across the river. On the south side of the river, the Hamner Bluff Formation dips about $10^{\circ} \mathrm{SW}$. and overlies sandstone of the Puget Group that dips $20^{\circ}-25^{\circ} \mathrm{S}$. In some exposures, iron-stained Hammer Bluff sediments of the upper member overlie Puget Group saudstone that is weathered and leached of iron oxide. Thus the Puget must have been leached before the Hamrer Bluff was deposited. Nearly flat-lying Orting(?) Drift, the oldest glacial drift in the area, unconformably overlies the Hammer Bluff Formation. A much hig:ter percentage of rolcanic pebbles in the Hammer BJuff are soft than in the Orting (?); presumably a period of weathering occurred between deposition of the two formations.

\section{SOURGE AND ENVIRONMENT}

The source rocks of the Hammer Bluff Formation probably were the arkosic rocks of the Puget Group and later the widespread Tertiary volcanic rocks, which were largely in the position of the present Cascade Range. Features such as the thinness and discontinuity of beds, the uniform composition, and the abundance of wood in the lower member of the Hammer Bluff, and the lithologic similarity of the lower member to Puget Group rocks, led Glover (1941; unpub. data, 1956) to suggest that it was derived locally from the Puget Group, which is the only nearby source for such abundant quartz. The upper member was derived mostly from preexisting volcanic rocks; older rolcanic rocks underlie most of the area naar Hammer Bluff that is not underlain by the Puget Group. The abundance of volcanic material in the upper member could have resulted either from uplift of the older volcanic rocks or from renewed volcanic activity in the area of the present Cascade Range. The volcanic ash, reported by Glover, and the pumiceous se diments in the formation show that eruptions did ocsur during Hammer Bluff time.

Crossbedding and channeling in the sand and gravel suggest that part of the formation is fluvial, but the woody silt and clay and lignite indicate that much of it is lacustrine, as suggested by Glover (1936). The presence of poorly sorted, thin, and interbedded fluvial and lacustrine sediments suggests that the Hammer Bluff Formation was deposited on a piedmont surface of low relief, which was characterized by flood plains and lakes. At the time of deposition of the Hammer Bluff, the Puget Sound lowland was bounded on the east by a low range at the position of Cascade Range that was not high and continuous enough to form a major moisture barrier (Chaney, 1938, p. 641). 


\section{AGE AND CORRELATION}

Glover (1936; 1941, p. 137) assigned the Hammer Bluff Formation to the Pliocene or preglacial Pleistocene; and Warren, Norbisrath, Grivetti, and Brown (1945) assigned it to the early Pleistocene. Each of these age assignments was based not on fossil evidence but on interpretation of physical evidence-the Hammer Bluff is more like Pleistocene deposits than lower Tertiary bedrock. Fossil leaves collected during this investigation suggest that the Hammer Bluff is late Miocene in age (R. W. Brown, written commun., 1956). The leaves were collected in the $\mathrm{NW}_{1} 1 / 4 \mathrm{SE} 1 / 4$ sec. 28 , T. 21 N., R. 6 E., across the Green River from Hammer Bluff, where they occur in lenses of silt and clay near the base of the upper member. The following species were identified by R. W. Brown of the U.S. Geological Survey (written commun., 1956) : Chamaecyparis sp., Fagus washoensis LaMotte, Ulmus sp., Carya egregia (Lesquereux) LaMotte-now called Carya bendirei (Lesquereux) Chaney and Axelrod ( $\mathrm{J}$. A. Wolfe, written commun., 1969) - ?Sassafras sp., and Acer sp. Samples from the same strata were analyzed for pollen by E. B. Leopold of the U.S. Geological Survey, and the following pollen were identified: Carya, Pinus, Pterocarya, Ulmus or Zelkova, Polypodiaceae, Alnus, Picea, Quercus, and fungal spores. According to Brown, the assemblage of plant fossils indicates a middle to late Tertiary age, and Fagus washoensis LaMotte is not known to have survived the Miocene in this area. On the basis of plant fossils from the Hammer Bluff and apparently correlative formations 10-15 miles farther south (Mullineaux and others, 1959), the formation is assigned a late Miocene age.

Sand and clay that contains woody lignite recovered from holes drilled for the Kent water system along Rock Creek in the NE1/4 SE1/4 sec. 26, T. 22 N., R. 6 E. (Ross Ellis, oral commun., 1957) probably is correlative with the Hammer Bluff Formation. These sediments, which are covered by drift of late Pleistocene age, are lithologically similar to those of the lower member of the Hammer Bluff Formation and are very different from recognized Pleistocene deposits in the area.

The Hammer Bluff Formation was correlated by Glover (1941) and by Warren, Norbisrath, Grivetti, and Brown (1945) with similar sand and clay in the Green River valley near Palmer, about 8 miles northeast of Hammer Bluff. Gower and Wanek (1963) tentatively assigned the late Miocene age determined for the Hammer Bluff Formation by Brown to the Palmer deposit, but they did not use the same name because they did not believe the two deposits were coertensive. A preliminary evaluation of seeds and pollen from the sediments at Palmer led R. W. Brown (written commun., 1957) to suggest that the Palmer deposit is younger than the deposit at Hammer Bluff. However, no sufficient further study could be made to confirm or deny this possibility.

On the basis of contained volcanic detritus and fossil leaves, some lacustrine and fluvial sediments exposed in the Lake Tapps quadrangle are also cc"related with the Hammer Bluff Formation (Mullineaux and others, 1959; Gard, 1968). These sediments crop out along Voight and Wilkeson (Gale) Creeks 10-15 miles south of the Hammer Bluff locality. They cl aracteristically are mudflows and alluvium that contain abundant pumice in some beds. The pumice is unusual in this area, because it contains abundant green hornblende and virtually no other ferromagnesian mineral. In contrast, most other Tertiary and Quaternary volcanic rocks in this area contain abundant pyroxene. Hornblende pumice is sparse but is also present in the Hammer Bluff Formation, and it probably was derived from the same general source as was the pumice in the deposits along Voight and Wilkeson Creeks.

Similar sediments of probable late Miocene age that also are characterized by content of hornblende pumice are exposed farther south along the west sid" of the Cascade Range. Near Eatonville, the pumiceous Mashel Formation (Walters, 1965) is a fluvial and lecustrine deposit of middle to late Miocene age. Farthor south near Castle Rock, the locally pumiceous fluvial and lacustrine Wilkes Formation is also consider?d to be late Miocene in age (Roberts, 1958).

The hornblende pumice in the Hammer Bluff and correlative formations is similar to the volcanic detritus in part of the Ellensburg Formation, which is of late Miocene and early Pliocene age. The Ellensburg crops out along the east flank of the Cascade Range from near Wenatchee (fig. 1) south to the Columbia River (Smith, 1903; Laval, 1956). Coombs (1941) noted that green hornblende and magnetite were virtually the only heavy minerals characteristic of the Ellensburg and suggested use of the distinctive mineralogic character for correlation. Later, J. E. Sceva of the U.S. Geological Survey (oral commun., 1954) mapped the Mashel Formation on the west side of the Cascades and proposed that it was equivalent to the Ellensburg Formation on the east side. The similarity of pumice in widespread formations on both sides of the Cascade Range suggests that the volcanic material was derived from widely distributed volcanic vents in the position of the present Cascades (Gard, 1960; Fiske and others, 1963). 


\section{PLEISTOCENE DEPOSITS}

Repeated glaciation in the Puget Sound lowland during Pleistocene time is recorded by the interbedding of glacial drift sheets and nonglacial deposits (table 1). The climate of some nonglacial episodes that separated the various glaciations was as warm as the climate is today, and the entire lowland probably was free of ice. The youngest glacial episode recorded in the mapped area - and that of which the record is by far the most complete-is the Vashon. Its drift mantles the surface over much of the Puget Sound lowland and has been traced northward into British Columbia. Distribution and character of the Vashon Drift show that the Vashon glacier originated in British Columbia and moved southward over the lowland, covering the entire area of this report and extending several tens of miles farther south (fig. 13; Bretz, 1913; Mackin, 1941). The northern origin of the glacier is shown by the content of the Vashon Drift. It contains numerous rocks and minerals that are sparse in or absent from the part of the Cascade Range that is drained by rivers that normally cross this part of the lowland, but that are common in ranges in British Columbia and the northern Cascades of Washington. Pre-Vashon drift sheets also contain a significant proportion of rocks and minerals from British Columbia and the northern Cascades. By analogy to the Vashon, the pre-Vashon drift sheets probably were also deposited by southward-moving ice from British Columbia. The lobe of ice that is inferred to have moved repeatedly into the lowland from the north is referred to as the "Puget glacial lobe" or "Puget lobe" (Bretz, 1913; Mackin, 1941; Crandell, 1963).

All the glacial-till deposits found in the mapped area contain typical northern rocks and minerals. Apparently glaciers from the adjacent Cascade Range did not reach that far out into the lowland. Therefore, the sediments termed "nonglacial" in the area include all those that are not derived from the Puget lobe. Some of these nonglacial sediments were deposited during

TABLE 1.-Sequence of geologic-climate units recognized in the southeastern part of the Puget Sound lowland (on the left) and the probable correlative geologic units exposed in the Renton, Auburn, and Black Diamond quadrangles (on the right) Crandell and others (1958)
Armstrong and others (1965)

Vashon Stade of the Fraser Glaciation . . . . . _. Vashon Drift Olympia Interglaciation . . . . . . . . . No unit recognized) Salmon Springs Glaciation _. . . . . . . . Salmon Springs Drift Puyallup Interglaciation........... _ _ Puvallup(?) Formation Stuck Glaciation.................... Intermediate drift Alderton Interglaciation.............. (No unit recognized) Orting Glaciation.

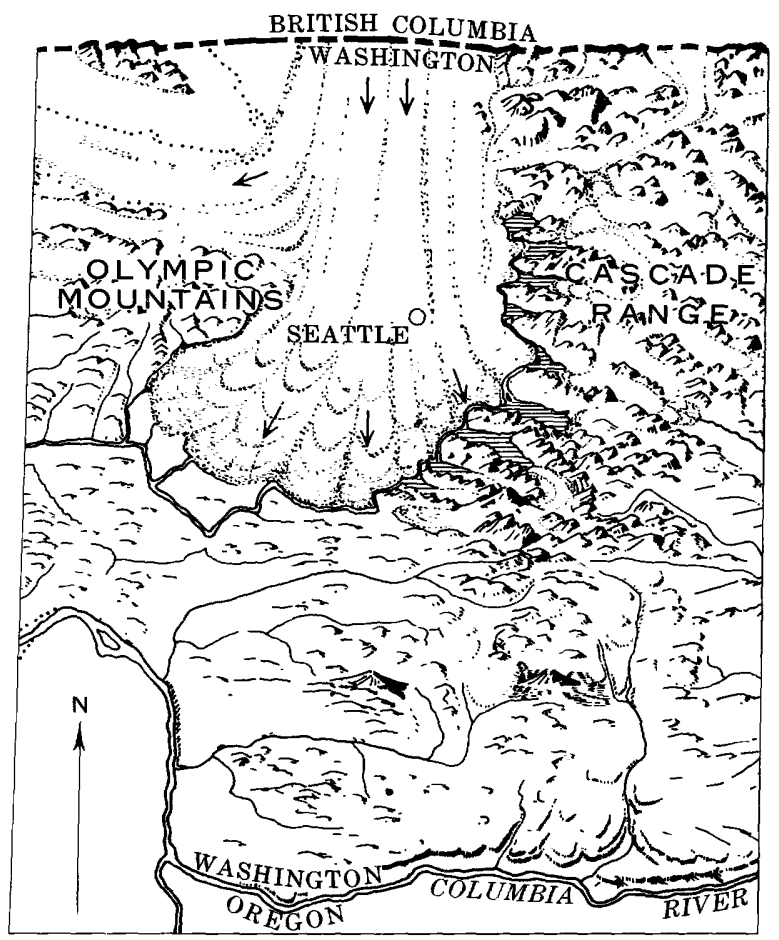

o 100 MILES

APPROXIMATE

Frgure 13.-Direction of movement of ice (Puget lobe) in the Puget Sound lowland of western Washington during the Vashon Stade. Adapted from Mackin and Cary (1965, fig. 8).

cool climates and others during warm climates. Scme, because they are like outwash in physical characteristics, are mapped with drift formations, whereas others are mapped as separate nonglacial units.

\section{SOURCES OF DETRITAL MATERIAL}

Pleistocene deposits of this part of the Puget Sond lowland consist of detrital material derived from t] ree principal source areas: (1) the part of the central Cascade Range that is south of Snoqualmie Pass and that is drained by the Cedar, Green, and White Rivers; (2) Mount Rainier; and (3) British Columbia and the northern part of the Cascade Range of Washington. In the discussions to follow, detrital material and deposits derived chiefly from the first two areas are referred to as being of Cascade provenance, and those derived from the third are referred to as being of nortl arn provenance. Where it is desirable to distinguish between the first two sources, they are termed "central Cascade" and "Mount Rainier," respectively.

Sediments of central Cascade provenance are exemplified by alluvium of the modern Cedar and Green Rivers where the river deposits have not been con- 
taminated by drift from the Puget lobe. Alluvium of the White River, though the White also drains the central Cascades, consists chiefly of material from Mount Rainier. The Cedar and Green River deposits are dominated by fragments of Tertiary volcanic rocks, which consist of a wide variety of greenish-gray and light- to dark-gray andesitic, dacitic, and basaltic rocks, both porphyritic and dense. In alluvium from the Cedar River, light-gray granodiorite from the Snoqualmie Granodiorite or similar intrusive bodies is also abundant. Heavy minerals in alluvium from the Cedar and Green Rivers are chiefly hypersthene, hornblende, and opaque iron minerals. Every heavy-mineral suite studied, however, contains a significant proportion, up to about 50 percent, of rock fragments and altered unidentified grains (table 2). When the lowland is not occupied by ice, such detritus from the central Cascades is brought into the mapped area from the east. It is then carried across the area and beyond it to the north and west, for the riverflow reaches the ocean by way of the Puget Sound and the Strait of Juan de Fuca north of Seattle.

Modern sediments of Mount Rainier provenance are represented by alluvium of the White River. Older sediments from Mount Rainier, however, are better exemplified by Pleistocene volcanic mudflows and other volcanic sediments that are exposed directly northwest of the volcano in the Lake Tapps quadrangle (Cran- dell, 1963). Modern alluvium along the White Piver is characterized by sand and gravel composed of r rddishgray to grayish-red and light-gray to black pyroxene andesite. Heavy-mineral suites consist chiefly of hypersthene but also include a very small proportion of hornblende plus opaque iron minerals, altered grains, and rock fragments (table 2). Older deposits of Mount Rainier provenance are characterized by light-gray to black and reddish-gray hypersthene-hornblende andesite; their heavy-mineral suites are similar to those from modern sediments but contain a larger proportion of hornblende (Crandell, 1963). Like the Cedar and Green Rivers, the White carries its sediments across and northwestward beyond the limits of the rapped area.

The typical example of sediments of northern provenance is the Vashon Drift. Only part of the material in the drift, however, can be identified as nctherm. The drift contains abundant andesitic and grarodioritic stones, for example, that could have been derived either from the northern or from the central farts of the Cascade Range. Furthermore, the drift contains detritus of Cascade provenance that was carried north of the mapped area during nonglacial time, then picked up by the southward-moving Puget lobe. Th: drift does, however, include a significant proportion cf rocks and minerals that can be recognized as having a northerm source. Usually from 5 to 15 percent of the

TABLE 2.-Heavy-mineral suites in modern alluvium of the Cedar, Green, and White Rivers

[Based on counts of approximately 100 grains. All samples separated in bromoform (specific gravity approximately 2.86); magnetic grains removed with hand magnet. Abbreviations: $\mathrm{R}$, seen in slide, but not in 100-grain count; NC, not counted. Analysts: H designates J. C. Hathaway and H. C. Starkey; M designates aut 'ior]

\begin{tabular}{|c|c|c|c|c|c|c|c|c|c|c|}
\hline \multicolumn{4}{|c|}{ Sample } & \multicolumn{5}{|c|}{ Content (grain count) } & \multirow[b]{2}{*}{$\begin{array}{l}\text { Other } \\
\text { minerals }\end{array}$} & \multirow[b]{2}{*}{ Analyst } \\
\hline $\begin{array}{c}\text { Source } \\
\text { river }\end{array}$ & Locality & No. & $\begin{array}{l}\text { Grain } \\
\text { size } \\
(\mathrm{mm})\end{array}$ & $\begin{array}{c}\text { Pyroxene } \\
\text { (chiefly } \\
\text { hypersthene) }\end{array}$ & $\begin{array}{l}\text { Altered } \\
\text { Fe-Mg min- } \\
\text { erals and rock } \\
\text { fragments }\end{array}$ & $\begin{array}{c}\text { Amphibole } \\
\text { (chiefly } \\
\text { hornblende) }\end{array}$ & Garnet & $\begin{array}{l}\text { Opaque } \\
\text { minerals }\end{array}$ & & \\
\hline
\end{tabular}

Upvalley segments beyond the area covered by the Puget lobe drift

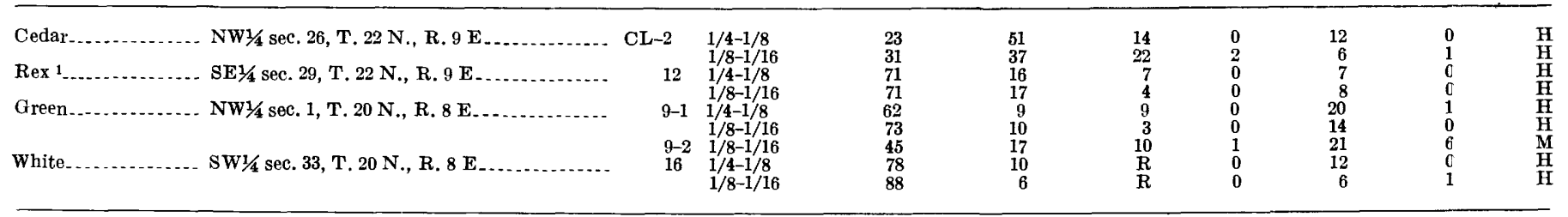

Downvalley segments in the area covered by the Puget lobe drift

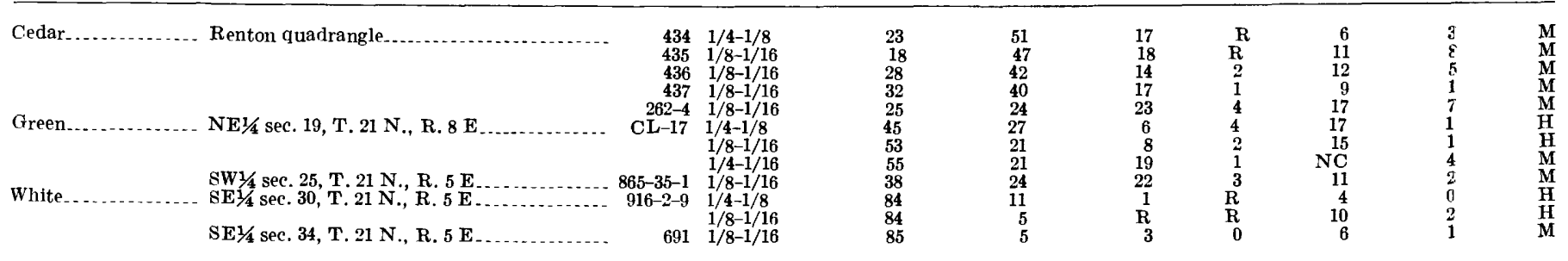

1 Tributary of Cedar River. 
stones are gneiss, schist, coarse-grained biotite granite, quartzite, and marble - rock types that are sparse in or absent from the alluvium of rivers that flow across the area in nonglacial time. Heavy-mineral suites in Vashon Drift consist largely of the same minerals as are present in alluvium of Cascade provenance, but they in addition contain abundant garnet and a wide variety of other minerals (table 3 ). That the abundant garnet was derived from the north is apparent from a comparison of heavy-mineral suites from sand of modern Cascade Rivers beyond the limits of the Puget lobe with those from Vashon Drift (tables 2, 3). In samples of sands from the Cedar, Green, and White Rivers that are uncontaminated by northern drift, garmet is sparse. Only one such sample contained as much as 2 percent of that mineral in any counted fraction. In samples from Vashon Drift, in contrast, garnet generally makes up several percent of the heavy-mineral suites, and in many samples it makes up at least 10 percent.

\section{CRITERIA USED TO ESTABLISH STRATIGRAPHY PROVENANCE}

The composition of Pleistocene deposits, to a certain extent, indicates their source and consequently whether they were deposited during glacial or nonglacial episodes. Sediments clearly of northern provenance iden-

TABle 3.-Heavy-mineral suites in Pleistocene sediments

[Based on visual estimates, in percent ( F, 10-25; A, 70-90; S, $<5 ; \mathrm{R},<1$ ), and on counts of approximately 100 grains. All samples separated in bromoform (specific gravity approximately 286 ) magnetic grains removed with hand met Analysts: H designates J.C. Hathaway and H.C. Starkey; $M$ designates author]

\begin{tabular}{|c|c|c|c|c|c|c|c|c|c|c|}
\hline \multicolumn{3}{|c|}{ Sample } & \multicolumn{8}{|c|}{ Content } \\
\hline Locality & $\begin{array}{l}\text { Sample } \\
\text { No. }\end{array}$ & $\begin{array}{r}\text { Size } \\
(\mathrm{mm})\end{array}$ & $\begin{array}{l}\text { Pyroxene } \\
\text { (chiefly } \\
\text { hypers- } \\
\text { thene) }\end{array}$ & $\begin{array}{l}\text { Altered } \mathbf{F e}- \\
\text { Mg minerals } \\
\text { and rock } \\
\text { fragments }\end{array}$ & $\begin{array}{l}\text { Amphibole } \\
\text { (chiefly } \\
\text { hornblende) }\end{array}$ & Garnet & $\begin{array}{l}\text { Opaque } \\
\text { minerals }\end{array}$ & $\begin{array}{c}\text { Siderite } \\
\text { aggregates }\end{array}$ & $\begin{array}{c}\text { Other } \\
\text { minerals }\end{array}$ & Analyst \\
\hline
\end{tabular}

Till, Orting(?) Drift

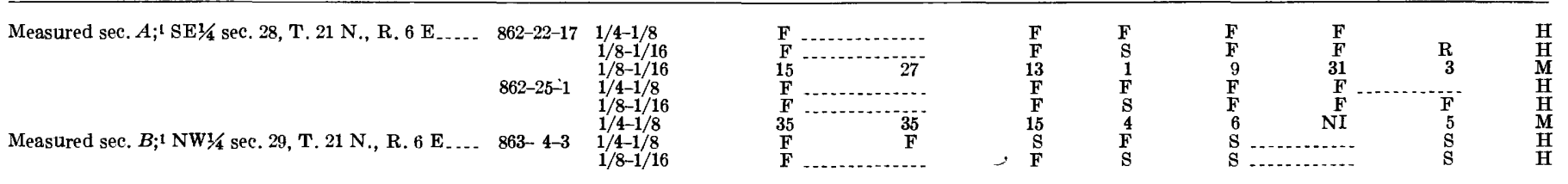

Intermediate drift

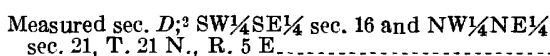

$\begin{array}{ll}863-4-1 & 1 / 4-1 / 8 \\ & 1 / 8-1 / 16 \\ 867-5-1 & 1 / 4-1 / 8\end{array}$

$\begin{array}{ll}867-5-1 & 1 / 4-1 / 8 \\ 867-6-1 & 1 / 8-1 / 16 \\ & 1 / 8-1 / 8\end{array}$

$\begin{array}{cccc}\mathbf{F} & \mathbf{F} & \mathbf{F} & \mathbf{F} \\ \mathbf{F} & \mathbf{F} & \mathbf{F} & \mathbf{F} \\ \mathbf{F} & \mathbf{F} & \mathbf{F} & \mathbf{S} \\ \mathbf{S} & \mathbf{F} & \mathbf{F} & \mathbf{F} \\ \mathbf{F} & \mathbf{F} & \text { F } & \text { F } \\ \mathbf{S} & \text { F } & \text { F } & \ldots\end{array}$

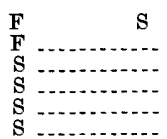

$\begin{array}{ll}\mathbf{S} & \mathbf{H} \\ \mathbf{S} & \mathbf{H} \\ \mathbf{S} & \mathbf{H} \\ \mathbf{F} & \mathbf{H} \\ \mathbf{S} & \mathbf{H} \\ \mathbf{S} & \mathbf{H}\end{array}$

Salmon Springs Drift

\begin{tabular}{|c|c|c|c|c|c|c|c|c|c|}
\hline $\begin{array}{l}\text { NE1/4 sec. } 2 \text {, T. } 20 \text { N., R. } 5 \text { E. } \\
\text { SE1/4 sec. 17, T. } 21 \text { N., R. } 5 \text { E. }\end{array}$ & $\begin{array}{l}920-7-6 \\
845-16-5\end{array}$ & $\begin{array}{l}1 / 4-1 / 8 \\
1 / 8-1 / 16 \\
1 / 4-1 / 8 \\
1 / 8-1 / 16\end{array}$ & $\begin{array}{l}\mathbf{F} \\
\mathbf{F} \\
\mathbf{F}\end{array}$ & F & $\begin{array}{l}\mathbf{F} \\
\mathbf{F} \\
\mathbf{F} \\
\mathbf{A}\end{array}$ & $\begin{array}{l}\mathbf{F} \\
\mathbf{S} \\
\mathbf{S} \\
\mathbf{S}\end{array}$ & $\mathbf{F}$ & $\mathrm{s}^{-1}$ & $\stackrel{-r}{\mathbf{R}}$ \\
\hline \multicolumn{10}{|c|}{ Vashon Drift } \\
\hline Measured sec. $A ;{ }^{1} \mathrm{SE} 1 / 4$ sec. 28, T. 21 N., R. $6 \mathrm{E} \ldots \ldots$ & $\begin{array}{l}845-16-6 \\
862-25-2\end{array}$ & $\begin{array}{l}1 / 4-1 / 8 \\
1 / 8-1 / 16 \\
1 / 4-1 / 8 \\
1 / 8-1 / 16\end{array}$ & $\begin{array}{l}\mathbf{F} \\
\mathbf{F} \\
\mathbf{F} \\
\mathbf{F}\end{array}$ & $\begin{array}{l}\mathbf{F} \\
\mathbf{F}\end{array}$ & $\begin{array}{l}\mathrm{F} \\
\mathrm{F}\end{array}$ & F & $\begin{array}{l}\mathbf{R} \\
\mathbf{F} \\
\mathbf{F}\end{array}$ & $\begin{array}{c}\mathrm{S} \\
\cdots \\
\cdots\end{array}$ & $\begin{array}{c}\mathbf{S} \\
\mathbf{F} \\
\mathrm{S} \\
\mathrm{F}\end{array}$ \\
\hline
\end{tabular}

Outwash, Vashon Drift

SW14 sec. 14, T. 23 N., R. 5 E _... . . . . 261-11-1 1/4-1/8

NW 14 sec. 34, T. 22 N., R. 6 E.

NE14 sec. 16 , T. 21 N., R. 6 E.

NW1,4 sec. 21, T. 21 N., R. 6 E

$\mathrm{SE} 1 / 4$ sec. 26 , T. 22 N., R. $5 \mathrm{E}$.

SW 14 sec. 17, T. 21 N., R. 5 E

$\begin{array}{cl}261-11-1 & 1 / 4-1 / 8 \\ & 1 / 8-1 / 16 \\ 792-1-1 & 1 / 4-1 / 8 \\ & 1 / 8-1 / 16 \\ & 1 / 8-1 / 16 \\ 852-1-1 & 1 / 4-1 / 8 \\ & 1 / 8-1 / 16 \\ 852-2-1 & 1 / 4-1 / 8 \\ & 1 / 8-1 / 16 \\ 787-18-1 & 1 / 4-1 / 8 \\ & 1 / 8-1 / 16 \\ 845-43-1 & 1 / 4-1 / 8 \\ & 1 / 8-1 / 16\end{array}$

$\begin{array}{ll}22 & 52 \\ 31 & 25 \\ 29 & 51 \\ 44 & 34 \\ 30 & 39 \\ 36 & 46 \\ 47 & 31 \\ 31 & 43 \\ 24 & 48 \\ 27 & 48 \\ 23 & 47 \\ 29 & 41 \\ 29 & 36\end{array}$

$\begin{array}{rrrr}52 & 9 & 10 & 7 \\ 25 & 27 & 5 & 9 \\ 51 & 10 & 2 & 8 \\ 34 & 9 & \text { NI } & 9 \\ 39 & 11 & 6 & 10 \\ \mathbf{4 6} & 5 & 7 & 7 \\ 31 & 2 & 6 & 13 \\ \mathbf{4 3} & 7 & 5 & 15 \\ \mathbf{4 8} & \mathbf{2} & \mathbf{3} & 6 \\ 48 & 5 & 5 & 16 \\ \mathbf{4 7} & 23 & 3 & 3 \\ \mathbf{4 1} & 12 & 5 & 13 \\ \mathbf{3 6} & \mathbf{2 4} & \mathbf{3} & 7\end{array}$

$\begin{array}{rlll}\mathbf{7} & 0 & 0 & \mathrm{H} \\ 9 & 0 & \mathbf{3} & \mathbf{H} \\ \mathbf{8} & 0 & 0 & \mathrm{H} \\ \mathbf{9} & 0 & \mathbf{3} & \mathrm{H} \\ \mathbf{1 0} & 0 & \mathbf{4} & \mathrm{M} \\ \mathbf{7} & 0 & 0 & \mathbf{H} \\ \mathbf{1 3} & 0 & \mathbf{1} & \mathbf{H} \\ 15 & 0 & 0 & \mathrm{H} \\ 6 & 0 & 0 & \mathbf{H} \\ 16 & 0 & 0 & \mathrm{H} \\ \mathbf{3} & 0 & 2 & \mathrm{H} \\ \mathbf{1 3} & 0 & 0 & \mathbf{H} \\ 7 & 0 & 1 & \mathbf{H}\end{array}$

See figure $14 . \quad 2$ See figure 17. 
tify stratigraphic units of glacial drift. They record presence of the Puget lobe in the lowland, even where the sediments do not include till. Sediments wholly of Cascade provenance, on the other hand, identify nonglacial stratigraphic units. During their deposition, the Puget lobe was distant enough that it did not contribute material to them. A succession of glacial and nonglacial episodes, with respect to the Puget lobe, can thus be determined by examining the lithology of sediments in a stratigraphic sequence.

The provenance of many coarse sediments can be determined by identification of constituent stones. For deposits in which pebbles are sparse, the proportion of garnet among heavy minerals can be substituted. Like pebble counts, estimates of garmet proportions are useful in the field; in gold-pan concentrates from coarse or medium sand, garnet typically is readily seen with a hand lens because of its prevalent red and orange colors. For concentrates from finer sand, however, it commonly is necessary to examine the minerals under a inicroscope.

Counts and estimates of garnet proportions encounter some problems that are not involved in pebble counts. Interpretation of both pebble and mineral proportions must allow for an apparent gradation of types from certainly northern to certainly Cascade sediments, probably resulting from mingling of Puget lobe melt water and Cascade rivers, and because of some reworking of drift by the Cascade rivers. But use of heavy-mineral proportions must also allow for variations resulting from handling of the sample. Handling causes variety in heavy-mineral proportions because of such factors as shape, density, and size of minerals. Garnet, for example, is nonuniformly discarded from a gold pan with the lightweight fraction, whereas tabular minerals are relatively concentrated (Theobald, 1957). Even laboratory separation by heavy liquids may produce variable results, for the garnets tend to roll and congregate irregularly in a sample.

In spite of limitations of the garnet-proportion method, the determined proportion of garnet seemed to be adequate to distinguish many strata as either of northern or of Cascade provenance. In this study, sediments in which garnet was absent or sparse were regarded as clearly of Cascade provenance and therefore nonglacial. Those in which garnet made up only a few percent of the heavy-mineral fraction were regarded as not identifiable on the mineral proportions alone, and of doubtful provenance in the absence of other evidence. Only those sediments in which garnet made up more than about 5 percent of the heavy fraction were regarded as of northern provenance and therefore glacial on the basis of mineral proportions.

\section{CLIMATE}

Evidence of past climates not only is useful in distinguishing nonglacial from glacial sediments, hut also in indicating, for times of nonglacial sedimentation, whether the glacier had made a major or a minor retreat. The climate that existed during deposition of many nonglacial deposits is recorded by the t.rpes of pollen and diatom fraginents they contain.

Hansen and Mackin (1949) snowed that pollen analyses could be used to determine the climste that existed during deposition of some stratigraphic units in the Puget Sound lowland. Further, they showed that pollen and stratigraphic studies together could be used to demonstrate a succession of pre-Vashon glacial and nonglacial episodes. Pollen analyses and resulting paleoclimatic interpretations applied to this study were made by E. B. Leopold of the U.S. Geological Survey. The interpretations are based on comparison of counts of tree pollen from pre-Vashon sediments from the mapped area with tree-pollen counts from the uppermost deposits in modern peat bogs at various altitudes in the Pacific Northwest (Hansen, 1947). Fossil pollen assemblages that indicate a forest similar to thet existing today in the lowland, for example, are used to infer a comparably mild climate in the lowland at the time the pollen-bearing sediments were laid down. Similarly, pollen that indicate a forest like that abore 5,000 feet in the Cascades today suggest cool and moist conditions in the lowland during deposition of the enclosing sediments.

Identifications of diatoms and interpretations of their depositional environments were made by $\mathrm{K}$. $\mathrm{E}$. Lohman of the U.S. Geological Survey. Forsil assemblages that consist of species living in water with a temperature range like that in the Puget Sound lowland today (termed "Inoderate" or "temperate") or warmer are regarded as indicating that the climate in the lowland during their deposition was as warm as it is now.

\section{WEATHERING}

Weathering that has been recognized in the mapped area consists chiefly of iron staining and decomposition of pebbles. No well-developed pre-Vashon soil profiles, and only one probable profile, have been found. Some of the oxidation zones that are common, however, probably represent parts of expanded soil profiles. Nearby, weathering profiles have beer recognized in the Lake Tapps quadrangle (Crandell, 1963), in Seattle (Mullineaux and others, 1964), and in a few other places in the Puget Sound lowland (Bretz, 1913). 
Iron oxide stains Pleistocene deposits various shades of brown-the deposits are then termed "oxidized"or it stains them bluish to greenish gray-they are then termed "reduced." Most pre-Vashon formations are deeply stained, and an intense color due to staining that is spread throughout a formation is regarded as evidence of pre-Vashon age. Permeable sediments are most strongly stained. Well borings suggest that the sediments are in a reduced state at depth, but they typically are oxidized to brown near the surface. Sediments containing abundant disseminated peat or wood are commonly gray even at the surface, or if the organic material is scattered, are mottled in gray and brown. Relatively impermeable sediments such as clay and till generally are stained along fractures and around stones mainly by concentrations of iron oxide. Sediments from Mount Rainier differ from most other deposits in that they typically are not iron stained even where permeable.

Vashon Drift generally is stained in only the uppermost few feet. Till at the ground surface typically is oxidized to a light yellowish brown to depths of $2-4$ feet, depending on permeability. Below the surface zone, it is nearly uniformly olive gray and does not contain notable concentrations of iron oxide along fractures or around pebbles. Permeable Vashon outwash commonly is oxidized to depths of 6-8 feet, though zones of oxidation occur irregularly at greater depths. Locally, the Vashon sediments are strongly stained by iron oxide, but overall oxidation of the formation was not seen anywhere.

Decomposition of stones can be used to differentiate some pre-Vashon sediments from Vashon Drift. Partly decomposed stones are common in many older sediments, but are sparse in Vashon deposits. Where such stones are abundant, they indicate a pre-Vashon age.

\section{STRATIGRAPHIC SEQUENCE}

Pleistocene deposits in the Puget Sound lowland in and southeast of Seattle record at least four glaciations separated by interglacial intervals (table 1; Mullineaux and others, 1957; Crandell and others, 1958). The three pre-Vashon glacial and the two intervening interglacial episodes are named for formations that crop out in the Puyallup Valley; they are the Orting Glaciation (oldest), Alderton Interglaciation, Stuck Glaciation, Puyallup Interglaciation, and Salmon Springs Glaciation (Crandell and others, 1958). Vashon Drift lies on Salmon Springs Drift in the Puyallup Valley, but deposits of another interglaciation, the Olympia, separate the two drifts in some other parts of the lowland (Armstrong and others,
1965). The stratigraphic sequence in the mapped srea is the Orting(?) Drift, an unnamed intermediate drift, the interglacial Puyallup(?) Formation, Salmon Springs Drift, and Vashon Drift.

\section{ORTING(?) DRIFT}

The oldest deposits recognized as Pleistocene are stony till and outwash that lie on Tertiary formations along the Green River southwest of Black Diamond (Mullineaux, 1965c). These deposits are similar in lithology and stratigraphic position to the Orting Drift of the Puyallup Valley and are tentatively correlated with it. The name Orting was first assigned by Willis (1898c) to gravel that is typically exposed near the town of Orting in the Puyallup Valley. Because till is interbedded with the gravel, the Orting Gravel as used by Willis has been redefined as Orting Drift (Crandell and others, 1958, p. 387).

\section{LITHOLOGY}

The Orting ( ?) Drift along the Green River concists predominantly of brown sand and gravel that contains lenses and sheets of till, silt, and clay. Locally, deposits of probably lacustrine gray to brown sand, silt, and clay are thick. Sections $A$ and $B$ are composite sections that illustrate the lithology of the formation where it is well exposed.

Section A. South valley wall of the Green River in $S E 1 / 4$ sec. 28, T. 21 N., R. 6 E.

[Lower three units of Orting(?) Drift measured about a quarter of a mile northwest of main exposure]

Vashon Drift: Sand, pebbly, gray to yellowish-gray, friable_._._. 15

Till, stony, gray, compact; contains gravel and clay lenses (sample 862-25-2) ... . . . . . . . . .

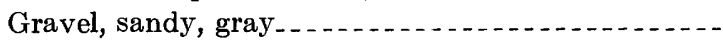
Orting(?) Drift:

Sand, medium and fine, grayish-brown, horizontally

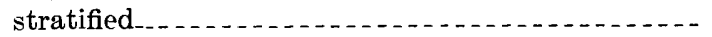

Gravel, pebble-and-cobble, reddish-brown to grayishbrown

Till, stony, mottled gray to reddish-brown; darkreddish-brown iron oxide concentrated along joints and around pebbles (sample 862-25-1) .....-

Gravel, cobble, bouldery, reddish-brown; lies in channels and contains blocks of underlying sand - 5-15

Sand, medium to coarse, reddish-brown

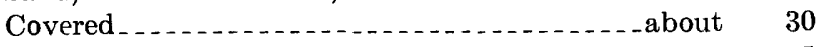

Gravel, boulder, reddish-brown ............... 5

Sand, coarse to medium, reddish-brown to grayishbrown; upper 3-5 ft strongly iron stained......-

Till, stony, mottled gray to reddish-brown; darkreddish-brown iron oxide concentrated along joints and around pebbles (sample 862-22-17)

Hammer Bluff Formation...................... 15
Tiuck-

70 5 
Section B. South side of the Green River in cutoff spur, NW1/4 sec. 29, T. 21 N., R. 6 E. [Lower three units of Orting(?) Drift measured about 600 feet east of upper part of

Vashon Drift:

Till, stony, gray $\ldots \ldots$

Gravel, pebble, olive-gray

Salmon Springs Drift:

Sand, medium, yellowish-brown

Gravel, pebble-and-cobble, brown

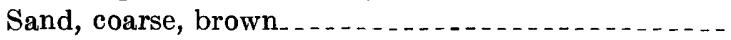

Intermediate drift:

Till, mostly silt and clay, olive-gray ..........

Gravel, pebble-and-cobble, sandy, brown . . . . . . . .

Sand and silt, yellowish-gray _.............. 10-15

Till, mostly silt and clay, olive-gray; increases in thickness westward to more than $100 \mathrm{ft}$ (sample 863-4-1)

Orting(?) Drift:

Till, stony, mottled olive-gray to reddish-brown, iron oxide coatings around stones and along fractures (sample 863-4-3) . . . . . . . . . . . . . 10-15

Gravel, pebble-and-cobble, yellowish-brown to reddish-brown; contajns stones probably derived from an ancestral Mount Rainier, and lenses of bluish- to greenish-gray silt and clay .

Sand, medium to coarse, yellowish- to reddishbrown

Break in continuous exposure.

Sand, fine to medium, light-brown, horizontally bedded. . . . . . . . . . . . . . . . . . . . . . . .

Silt and sand, clayey, horizontally laminated; grades upward into fine and medium sand . . . . . _. _ 20-30

Till, stony, mottled olive-gray to reddish-brown; iron oxide coatings around stones and along fractures . . -

15

At least two and probably three till sheets or lenses in the Orting (?) Drift are exposed in the map area. Till strata lie at two stratigraphic horizons below thick sand of probable lacustrine origin at section $A$ (fig. 14). In addition, a lens of till that probably also is Orting (?) in age lies above the same sand in a nearby exposure. Till also lies both above and below a similar probably correlative thick sand at section $B$ (fig. 14). Typically, the Orting(?) till is very compact and stony; it consists of pebbles, cobbles, and a few widely separated boulders in a clayey sand and silt matrix (figs. 15, 16). The till contains rocks and heavy minerals of northern provenance (table 3), showing that it was deposited by the Puget lobe. The heavymineral suites, however, contain in addition to the minerals usually found in northern drift a large percentage of siderite and aggregates of siderite and clay. $\mathbf{X}$-ray analyses of three samples of matrix material show that almost all the clay minerals in the till are montmorillonite. Chlorite in small amounts is the only other clay mineral identified (table 4).

Roughly half the stratified drift that is well exposed on the south side of the Green River is sand of prob- able lacustrine origin; most of the remainder is fluvial sand and gravel. At measured section $B$ (fig̨. 14), clayey silt and sand overlie till and grade upward into fine and medium sand that is uniformly well sorted, horizontally bedded, and about 200 feet thick. The thick sand is overlain by crossbedded coarse sand and gravel that is, in turn, overlain by till. At measured section $A$ (fig. 14), thick and uniform horizontally bedded fine and medium sand overlies till and gravel at an altitude higher than at section $B$ and the sand is only 95 feet thick. The thick horizontally bedded sand and the underlying silt and clay are interpreted as deposits of a proglacial lake that formed in a depression in Orting(?) till and gravel.

Medium to coarse sand and pebble-and-cobble gravel prevail in the fluvial deposits that are well exposed. Boulder gravel, however, crops out in one extensive layer several feet thick in the lower part of the formation at measured section $A$. Silt and clay layers occur within the sand and gravel, but only as thin lenses. The sands and gravels typically are crossbedded and lenticular; individuat lenses vary greatly in thickness and horizontal extent. Channeling of underlying beds and cut-and-fill structural features are commor.

Like the till, the stratified drift contains roc $^{l}$ s and minerals of northern provenance. The lacustrine sand, however, contains fewer identifiable northern minerals; the sand probably contains a considerable amount of detritus brought in by Cascade rivers that flowed along the east margin of the Puget lobe during Orting time.

Organic material is not common in the Orting(?) except in one general locality on the south side of the Green River in the west half of sec. 28 and in the east half of sec. 29 , T. 21 N., R. 6 E. Wood fragments, some of which are logs more than a foot in diameter, are abundant in gravel and sand along Newaukum Creek in sec. 29 that is mapped as part of the Orting(?) Drift. Wood fragments are also abundant in a single exposure of Orting(?) till in sec. 28 along Whitney Hill Road in 1956, but these wood fragments are small, generally less than an inch across.

\section{WEATHERING}

The Orting(?) contains some decomposed stones, and it is stained and weakly cemented in places by iron oxide. It also contains abundant, probably secondary siderite and nontmorillonite clay minerals. It is the most weathered of the Pleistocene formations but is distinctly less weathered than the underlying Hanmer Bluff Formation. Nearly all the Orting(?) is stained by iron oxide. The permeable gravel or sand 


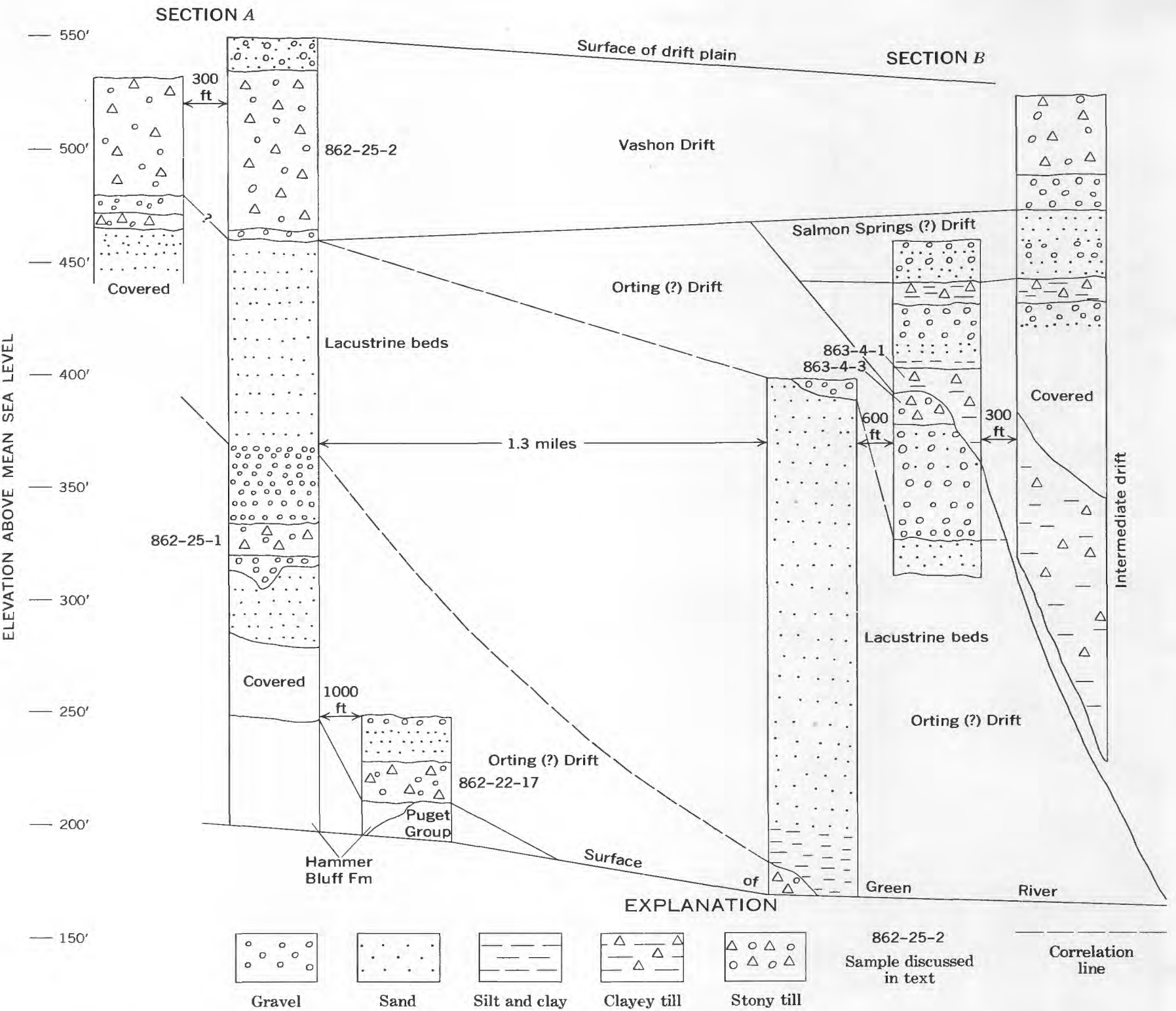

Figure 14.-Sketch of sections $A$ and $B$ in south valley wall, showing Orting(?) Drift. Section $\dot{A}$ is in SE1/4 sec. 28 , T. 21 N., R. 6 E., and section $B$ in NW1/4 sec. 29 , T. 21 N., R. $6 \mathrm{E}$.

typically is various shades of yellowish or reddish brown. The silt and clay, however, typically is bluish to brownish gray. The till generally is stained brownish gray or mottled brown and gray, and almost all stones and fractures are coated with dark-brown iron oxide. Some of the constituent montmorillonite clay minerals probably were picked up by the glacier from the underlying, deeply weathered materials. However, montmorillonite is prevalent in till layers that are high in the formation (table 4, sample 862-25-1) and that probably represent readvances of the ice over fresh drift. It seems likely that much of the montmorillonite was formed in place by weathering.

\section{DISTRIBUTION AND THICKNESS}

Orting(?) Drift has been recognized only along the valley walls of the Green River and Newaukum Creek in the eastern part of the Black Diamond quadrangle. The entire formation dips westward slightly, but more steeply than the slope of the Green River valley floor or of the drift plain. Between measured sections $A$ and $B$. the oldest till and fluvial deposits pass out of sight beneath the flood plain, and apparently successively 


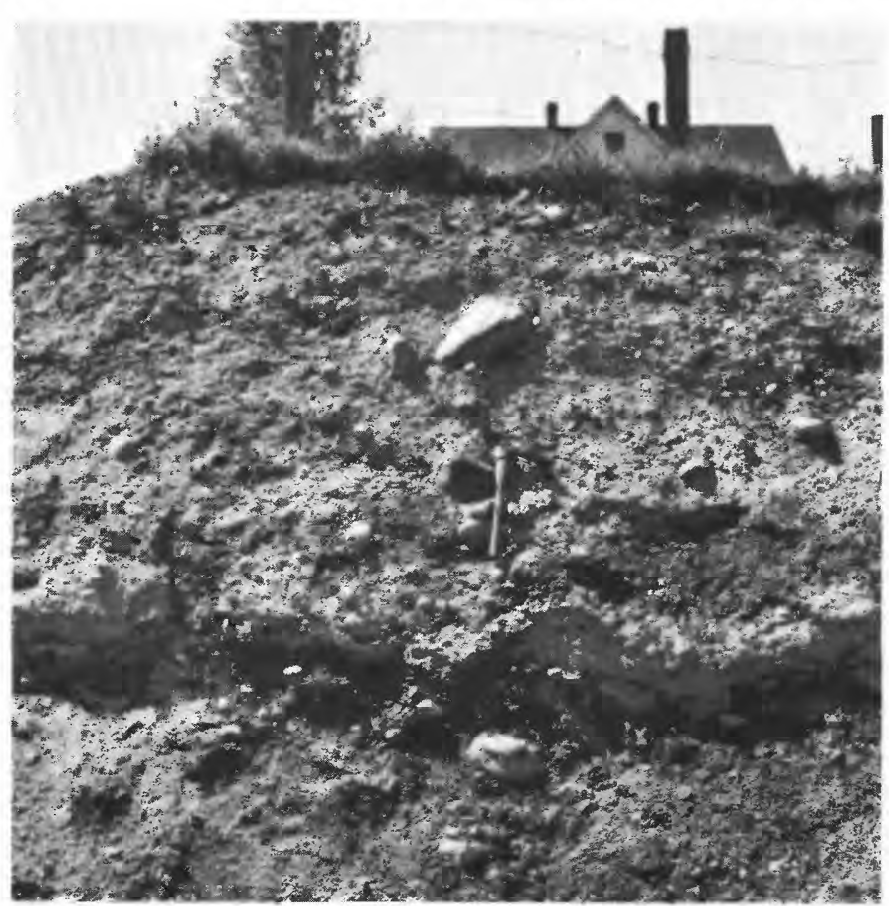

A

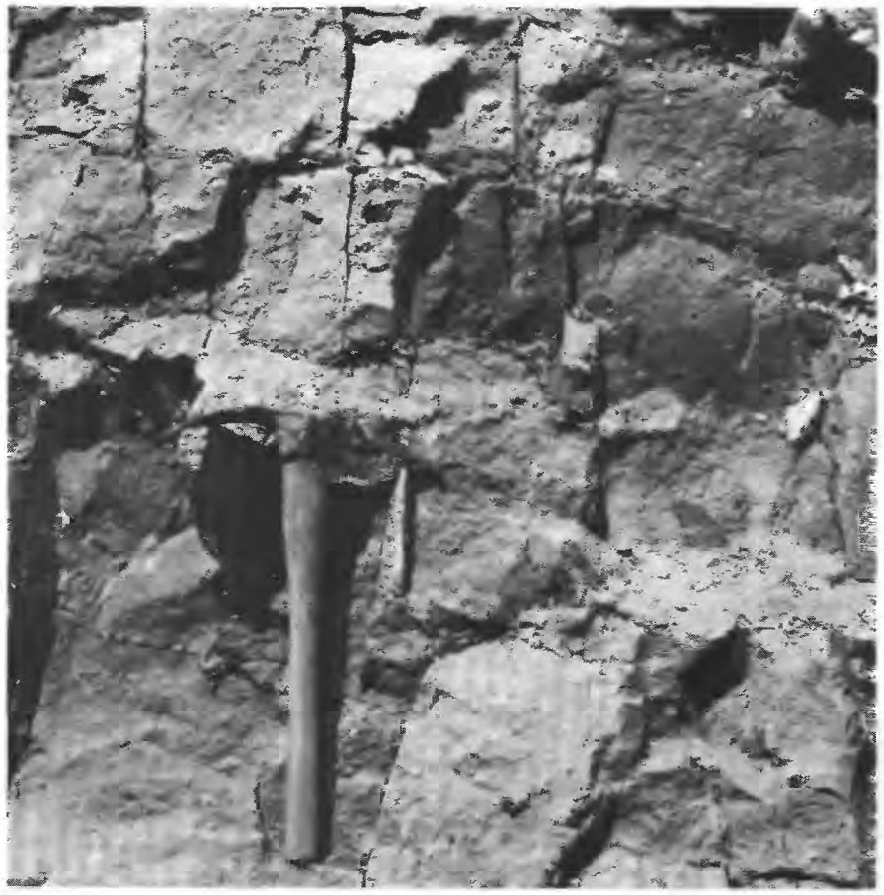

$C$

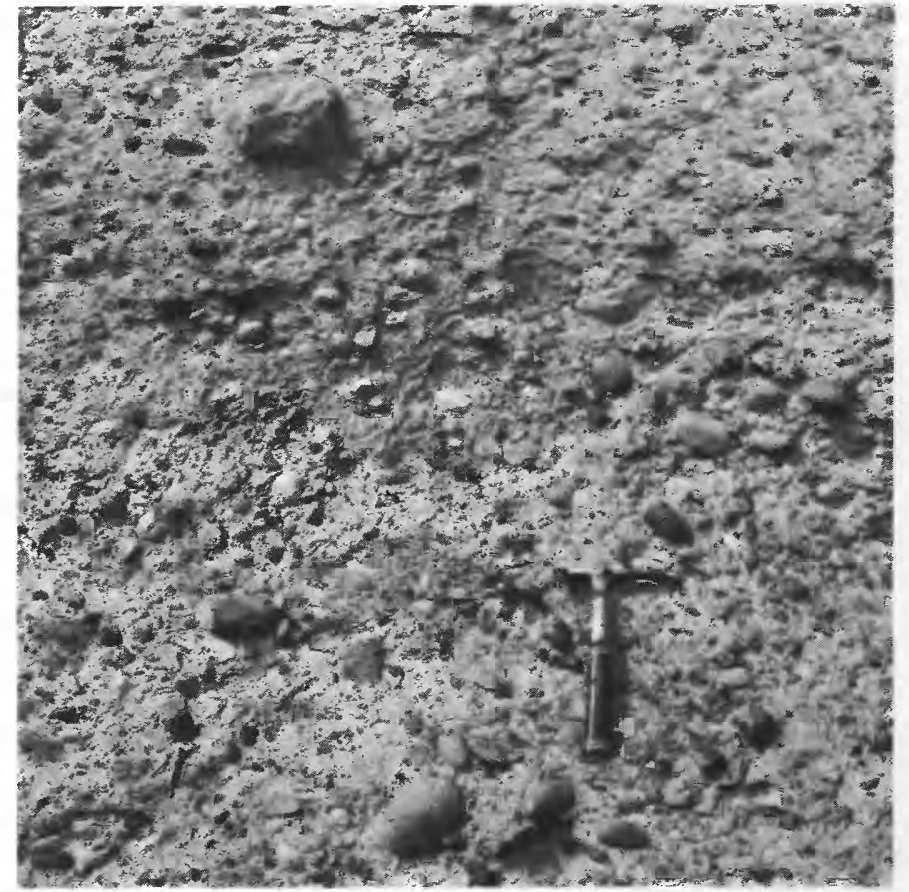

$B$

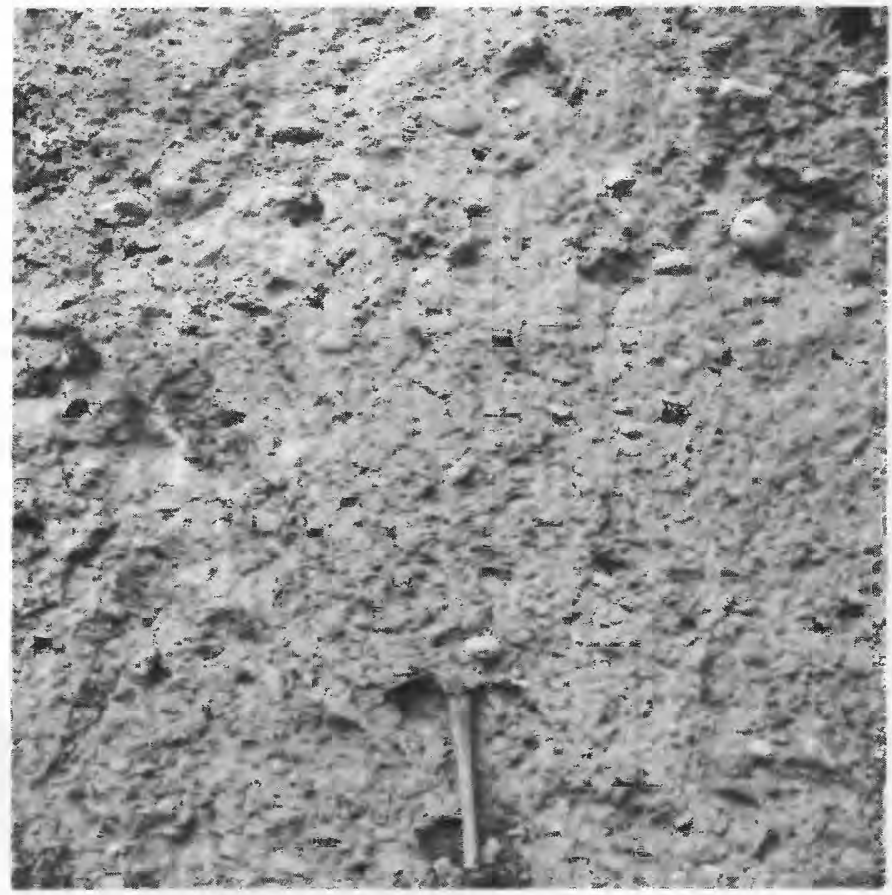

D

FIGURE 15.-Comparison of textures of representative till deposits in $A$, Vashon Drift; $B$, Salmon Springs Drift; $C$, intermediate drift; and $D$, Orting (?) Drift.

younger strata are exposed in the upper part of the drift (fig. 14).

The thickest section of Orting(?) Drift exposed is at section $B$, where lacustrine silt and clay crop out at river level. Because fluvial sediments and till underlie the lacustrine deposits elsewhere, the formation probably is considerably thicker than the 230 feet exposed at section $B$. 


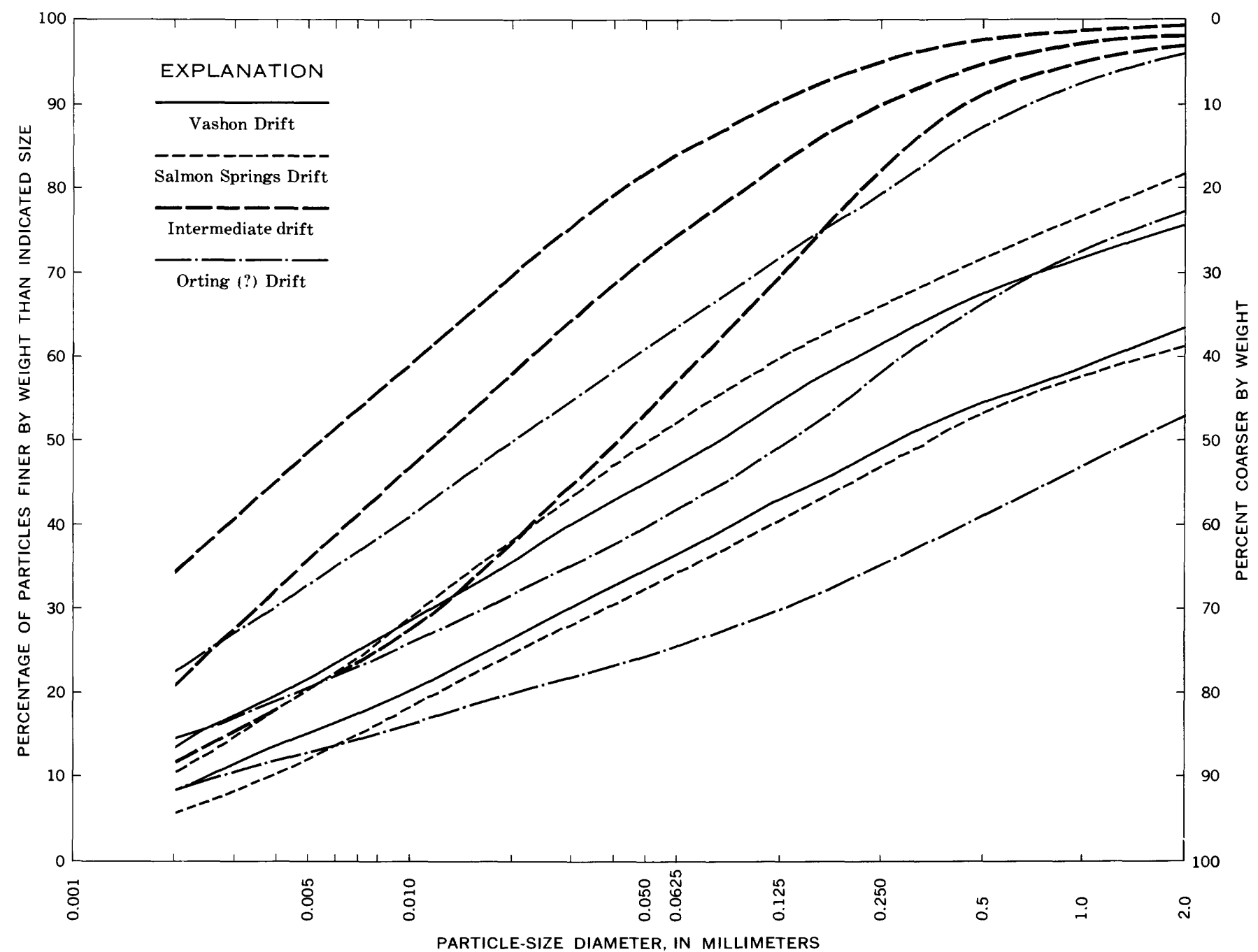

FIgure 16.-Cumulative particle-size distribution curves of glacial till samples from Vashon Drift, Salmon Springs Drift, intermediate drift, and Orting(?) Drift.

\section{STRATIGRAPHIC RELATIONS}

The Orting(?) Drift overlies the Hammer Bluff Formation with a slight angular unconformity. In 1956, the contact was well exposed in the commercial sandpit at Hammer Bluff and in natural exposures across the river to the south. In most exposures, the Orting (?) is overlain directly by Vashon Drift, but at measured section $B$ (fig. 14), it is overlain with sharp erosional unconformity by intermediate drift. No profile of weathering was recognized in the Orting (?), but there is an overall difference in montmorillonite clay content between it and the intermediate drift (table 4) that suggests an interval of weathering between the deposition of the two drifts.

\section{INTERMEDIATE DRIFT}

The formation next younger than the Orting(?) in the mapped area is an unnamed drift here informally termed "intermediate." This stratigraphic unit, which consists mostly of two fine-grained clay-rich till members separated by $50-175$ feet of stratified sediments, crops out along the Green and White River valley walls. The intermediate drift lies between formations that are tentatively correlated with the Orting Drift and Puyallup Formation of the Puyallup Valley. Its position thus suggests equivalence with drift of the Stuck Glaciation (table 1), but it cannot be traced to that formation. The intermediate drift, furthermore, is strikingly dissimilar to the type Stuck Drift that is only about 8 miles to the southwest. The type Strack is thin and contains only a single till member that is coarse grained and stony. Because of the lithologic difference, it does not seem likely that the intermediate drift is an extension of the Stuck Drift exposed in the Puyallup Valley. It does seem likely that the intermediate drift was deposited at some time during the 
TABLE 4.-Mineralogy of silt and clay fraction of tills [Tr., trace. Analysts: Dorothy Carroll, P. D. Blackmon, J. C. Hathaway, H. C. Starkey, and Gillison Chloe]

\begin{tabular}{|c|c|c|c|c|}
\hline \multicolumn{3}{|c|}{ Sample } & \multicolumn{2}{|l|}{ Mineralogy } \\
\hline Locality & No. & Size 1 & Minerals & $\begin{array}{c}\text { Estimated } \\
\text { content } \\
\text { (parts in 10) }\end{array}$ \\
\hline \multicolumn{5}{|c|}{ Vashon Drift } \\
\hline $\begin{array}{l}\text { Measured sec. } E ;{ }^{2} \\
\text { center sec. } 17, \text { T. } 21 \\
\text { N., R. } 5 \text { E. }\end{array}$ & $845-16-6$ & Clay...... & $\begin{array}{l}\text { Montmorillonite } \\
\text { Chlorite } \\
\text { Quartz } \\
\text { Plagioclase } \\
\text { Mica } \\
\text { Quartz } \\
\text { Plagioclase } \\
\text { Chlorite(?) }\end{array}$ & $\begin{array}{r}4 \\
2 \\
1 \\
1 \\
1 \\
5 \\
4 \\
\text { Tr. }\end{array}$ \\
\hline $\begin{array}{l}\text { Measured sec. } A i^{3} \text { SE1/4 } \\
\text { sec. } 28 \text {, T. } 21 \text { N., R. } \\
6 \mathrm{E} .\end{array}$ & $862-25-2$ & $\begin{array}{l}\text { Clay... } \\
\text { Silt.... }\end{array}$ & $\begin{array}{l}\text { Montmorillonite } \\
\text { Chlorite } \\
\text { Quartz } \\
\text { Plagioclase } \\
\text { Mica } \\
\text { Quartz } \\
\text { Plaglociase............. }\end{array}$ & $\begin{array}{r}3 \\
2 \\
2 \\
2 \\
2 \\
\text { Tr. } \\
5 \\
4\end{array}$ \\
\hline
\end{tabular}

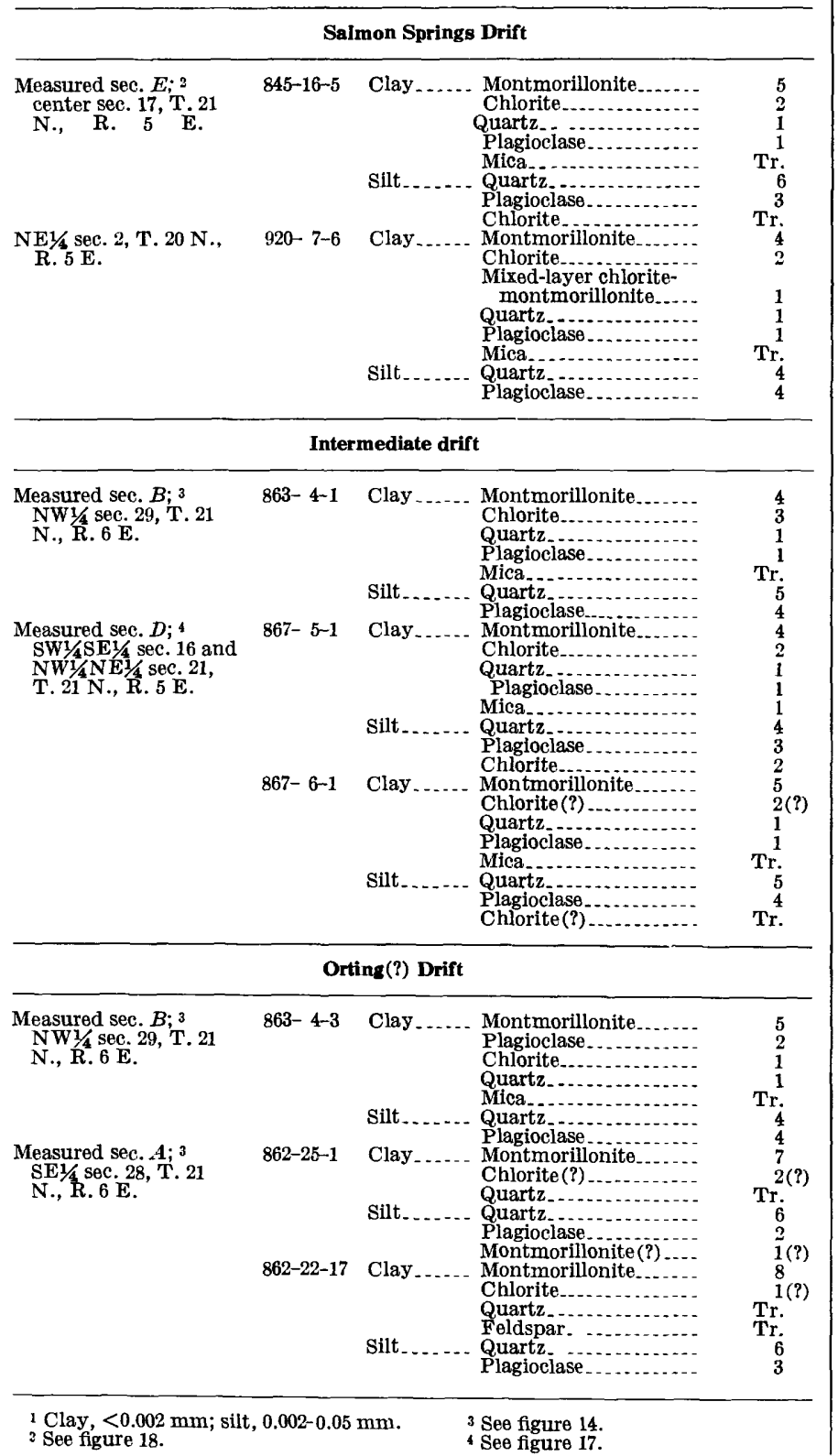

Stuck Glaciation, yet it is possible that it resulted instead from a glaciation not represented in the Puyallup Valley sequence. For that reason, and because of the lithologic difference, the term "Stuck" is not applied to the intermediate drift of this report.

The upper part of the intermediate drift of this report is correlative with the lower of two drift sheets first described as intermediate in the Buckley quadrangle (Crandell and Gard, 1959). The low?r drift sheet there was later assigned to the Stuck Drift by Crandell (1963).

\section{LITHOLOGY}

The intermediate drift consists of fine-grained till, lacustrine silt, clay, and sand, fluvial sand, and minor amounts of gravel. Deposits exposed on the scuth and north walls of the Green River valley east of Auburn (sections $C$ and $D$; fig. 17) are typical of the formation.

Section C. South wall of Green River valley in secs. 25 and 36 , T. 21 N., R. $5 \mathrm{E}$.

Main section measured in SW1/4SW1/4 sec. 25; Puyallup(?) Formation measured in NE $1 \frac{1}{4}$ NW1/4 sec. 36 , about a quarter of a mile farther southeart]

Thickness
(feet)

Osceola Mudflow

Vashon Drift:

Sand, pebbly, light-brown

Till, stony, olive-gray _....................... 25

Gravel, pebble, sandy, olive-gray _............ 15-20

Salmon Springs Drift:

Gravel, pebble-and-cobble, sandy, yellowish- to reddish-brown............................ 40-50

Puyallup(?) Formation:

Peat and silt _.................. 1-5

Sand, medium, ashy, pale-yellowish-gray _........ 5-10

Intermediate drift:

Till, mostly silt and clay, olive-gray _........... 10-30

Sand, and pebble gravel._.................. 10

Till(?), mostly silt and clay, olive-gray _.......... 2

Sand, medium and coarse, with some pebble gravel_- 100

Silt and clay, pebbly, laminated, bluish-gray to

brown, interbedded with fine sand .

Till, mostly silt and clay, olive-gray . . . . . . .

\section{Section D. North wall of Green River valley}

[Section measured in SW1/4SE1/4 sec. 16 and NW1/4NE1/4 sec. 21 , T. 21 N., R. 5 E. in cutbank of Green River and along Lake Holm Road]

Vashon Drift:

Gravel, pebble-and-cobble, sandy, yellowish-brow: . .

Thick-

Salmon Springs Drift

Gravel, pebble, sandy, brown; lenticular, locally contains blocks of clay and glacial till .............

Sand, medium to coarse, brown (not continuously

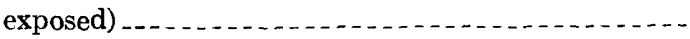

Intermediate drift:

Silt and clay, thinly laminated, bluish-gray _ _.. _. _ 20-25 Till, mostly silt and clay, olive-gray (sample 8675-1) $20-25$
10 
Section D. North wall of Green River valley-Continued

Intermediate drift-Continued

Sand, fine to medium, gray to brown; crossbedded in part, contains interbeds of silt.

Silt and clay, thinly laminated, yellowish-gray to brown. - . . .

Till, chiefly silt and clay, olive-gray (sample $867-$ 6-1)
Till occurs in the intermediate drift throughout almost all its mapped distribution. Both major till members appear to be extensive and to be nearly continuous sheets. No other thick or extensive till deposits are known in the formation, but local thin unstratified clayey silt layers containing scattered stones may s.lso be till.

65 The tills consist of widely separated stones in an
SOUTHEAST



$-350$

-200'

$-150$

$-100$

\section{SECTION $C$}

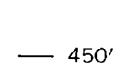

$-400^{\prime}$

Puyallup (?) Formation

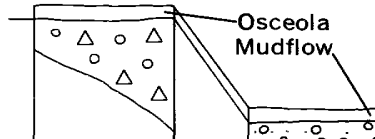

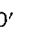

$-300^{\prime}$

$-250^{\prime}$

$-50^{\prime}$
Thick(feet) 
unsorted olive-gray to bluish-gray matrix of silt, sand, and clay. Overall, they are much less stony than most deposits of till in this region. Pebble- and granulesized material, which makes up large parts of till in other formations in the mapped area, constitutes only a few percent of samples of intermediate till (fig. 16). Locally, however, till in the intermediate drift is relatively coarse, especially at the tops of the two principal till members, and is somewhat similar in texture to other till deposits. Although the fine-grained tills contain thin lenses and blocks of stratified sand and silt, they are unstratified. They are also compact and cohesive, and fracture in a typically blocky pattern (fig. 15).

The fine-grained tills contain a slightly higher percentage of stones of northem provenance but otherwise are similar in composition to other glacial tills in the area. White marble and quartz pebbles are especially noticeable, because they are readily visible against the fairly uniform gray matrix. Clay minerals are chiefly montmorillonite and chlorite, but small amounts of fine-grained mica or illite are also found (table 4).

Exposed stratified drift consists mainly of sand, silt, and clay. Gravel is present but is sparse. Horizontally stratified, laminated, and thin-bedded silt and clay from a few feet to 50 feet thick generally overlies the lower till. Similar but thinner deposits also commonly overlie the upper till. Most of the other sediments are flat-bedded sands that probably also are lacustrine. Crossbedded coarse pebbly fluvial sand and even some gravel, characterized by cut-and-fill structures, occur, mainly in the middle and upper parts of the strata between the two till deposits. The stratified drift contains rocks and heavy minerals of northern provenance, but the proportion locally is low, especially in the fluvial materials. Between the two ice advances, which are represented by fine-grained till, the Puget lobe retreated enough to permit draining of the proglacial lake in which the lacustrine sediments were deposited. Fluvial sediments laid down next probably were derived in part from rivers heading in the Cascade Range.

\section{WEATHERING}

The intermediate drift appears considerably less weathered than the underlying Orting(?) Drift. Few stones in it are decomposed, and iron staining is less strong than in the Orting(?). The relatively weak iron staining probably is partly but not wholly due to the abundance of fine-grained strata. The finegrained tills generally are gray and show only small amounts of iron oxide accumulation around stones and along fractures. The abundant silt and clay strata are also generally gray; they show minor oxidation except for concentrations at the top where they are overlain by sand. Even some sand deposits are not noticeably oxidized. Overall, however, the sand is lightly stained to yellowish brown, and locally to a strong brown color. Along the White River, a thin zone of greenishbrown-probably weathered-clay occurs in the top of the formation below the Salmon Springs Drift. The weathered clay is at the same horizon at which a thin humified zone occurs in the Lake Tapps quedrangle (Crandell, 1963, p. A24).

\section{DISTRIBUTION AND THIGKNESS}

The intermediate drift crops out in both valloy walls of the Green River from about 1 mile east of Auburn to the middle of the Black Diamond quadrangle. The two fine-grained tills crop out along most of this distance and increase in altitude from west to enst (fig. 1i). The formation is well exposed at measured section $C$ and also at section $D$ (fig. 17). The drift also crops out along Big Soos Creek valley, but its extent there is poorly known because exposures are poor and distinctive fine-grained tills were not found more than a few hundred feet above the valley mouth.

The intermediate drift is also exposed in the White River valley. Outcrops of the drift are nearly continuous from about 1 mile from Auburn southeastward into the Lake Tapps quadrangle. The formation there dips less steeply than the gradient of the White River. Although both fine-grained tills crop out in downvalley exposures, upvalley the lower till passas below the flood-plain level before the quadrangle boundary is reached.

A mile north of Auburn, gray lacustrine clay, silt, and sand crop out in small exposures along the $\mathrm{Du}$ wamish Valley wall. Although typical fine-greined till is not exposed there, the sediments are mapped as intermediate drift, because lithologically they are similar to and only 2 miles from well-exposed intermediate drift at measured section $D$.

The maximum exposed thickness of intermediate drift is about 225 feet, in the Green River valley (measured section $C$; fig. 17). The upper till is generally from 10 to 35 feet thick, but the lower till is more variable in thickness. It commonly is about 40 feet thick, but is more than 60 feet thick ir several exposures, and apparently is nearly 200 feet thick at the east margin of the drift (fig. 14).

\section{STRATIGRAPHIC RELATIONS}

The intermediate drift overlies the Orting(?) Drift with a sharp erosional disconformity. Locally it is con- 
formably overlain by the Puyallup(?) Formation, but in most places it is overlain and channeled by Salmon Springs Drift. The conformable contact at its top is exposed in the south valley wall of the Green River at section $C$.

\section{ENVIRONMENT}

Lakes seemingly were widespread during the glaciation that produced the intermediate drift. That ponding was common in the Green River area is shown by abundant lacustrine sediments in the drift. Moreover, lakes apparently were widespread farther north in the lowland, where the Puget lobe must have picked up much of its load. Both the abundance of silt and clay and the low proportion of Cascade stones in intermediate tills suggest that, north of the Green River, the Puget lobe overrode more lake deposits and less coarse alluvium of Cascade Rivers during the intermediate glacial episode than during other glaciations.

The fine-grained tills typical of the intermediate drift are very similar in texture and structure to marine "tills" in British Columbia (Armstrong and Brown, 1954, p. 353) and in northern Washington (Easterbrook, 1963). No marine fossils, however, were found in the tills in the intermediate drift. Nor have exchangeable sodium cations, which suggest a marine origin for some similar deposits in Seattle (Mullineaux, 1967), been recognized in several analyzed samples. The textural similarity of the fine-grained tills to the marine "tills," as well as the abundant lacustrine sediments, suggests that the Puget lobe of the intermediate glacial episode advanced into and perhaps even floated in a proglacial lake.

\section{PUYALLUP(?) FORMATION}

Thin beds of sand of central Cascade and Mount Rainier provenance, and silt, clay, and peat lie above the intermediate drift and below Salmon Springs Drift. These sediments contain climatic evidence of interglacial conditions, but they could not be traced into either the Alderton or the Puyallup interglacial deposits of the Puyallup Valley. They are tentatively correlated with the Puyallup Formation because they directly underlie Salmon Springs Drift.

The name Puyallup Sand was established by Willis (1898c), who applied it to the compact gray sand of Mount Rainier provenance that is exposed along the Puyallup Valley, and to the interglacial episode represented by the sand. The name has since been changed to Puyallup Formation because the sand at the type locality is a facies of an assemblage of sand, gravel, and mudflow deposits of Mount Rainier provenence (Crandell and others, 1958).

\section{LITHOLOGY}

The Puyallup(?) Formation consists chiefly of sand, silt, clay, and peat but also contains volcanic ash and a rolcanic mudflow. The deposits are characterizec' by reddish-gray sand from Mount Rainier, by volcanic ash, and by peat deposits; peat is present in all deposits mapped as Puyallup(?). Peat exposed in the formation at the mouth of the Green River valley during this investigation is thin and mixed with silt and clay. Thicker, purer beds, however, from which blacksmiths regularly obtained "coke" many years ago, rere reported at that locality by local residents. In the Green River valley east of Auburn, peat in the formation ranges in thickness from a few inches to 4 feet. It is highly compressed, breaks with a distinct shaly fracture, and is classed as lignite (Cooper and Abernethy, 1941, p. 36). Several of these peat or lignite beds on the south wall of the valley have been $\mathrm{F}^{\text {ros- }}$ pected in the belief that they were coal beds in the Puget Group (Geer, 1941, p. 41). The deposits are high in inorganic material, however, and in the natural state contain more than 50 percent moisture (Cooper and Abernethy, 1941, p. 38).

Volcanic ash crops out in the Puyallup(?) Formation at the mouth of the White River valley south of Auburn (Mullineaux, 1965b) and on the south wall of the Green River valley in secs. 25 and 36 about 6 miles east of Auburn (Mullineaux, 1965c). At the first locality, ash associated with peat, silt, and clay occurs in several beds from river level to about 15 feet higher. The ash bed at river level is as much as 3 feet tlick. At the second locality, several ash beds, one of which is $21 / 2$ feet thick, are also exposed; here the ash is also associated with peat, silt, and clay. Diatom remains are abundant in the ash at both places.

Sand of Mount Rainier provenance, comparable to that in the type locality of the Puyallup Formation (Crandell and others, 1958), crops out along the $\mathrm{Du}$ wamish Valley north of Auburn, and along the White River valley. Similar sand, shown by augering to be more than 40 feet thick, underlies exposed Pryallup (?) deposits at the mouth of the Green River valley. It is a purplish-gray medium to coarse sand that is characterized by abundant red and gray andesite fragments and hypersthene.

Puyallup(?) deposits at the mouth of the Green River valley include a lens or sheet of till-like matrial interpreted as a volcanic mudflow from Mount Rainier. The mudflow is a hard, compact, and unsorted and 
unstratified stony mixture of sand, silt, and clay. It is distinguished from till by an abundance of angular mineral grains and stones, an abundance of material of Mount Rainier provenance, and its association with peat-bearing sediments.

\section{WEATHERING}

The Puyallup(?) Formation generally is light to dark gray, is not iron stained, and appears fresh. Few dense stones are soft, but many light-gray open-textured volcanic rocks are at least partly decomposed. No weathering profile on Puyallup(?) deposits has been found in the mapped area, though the top of the Puyallup Formation in the Lake Tapps quadrangle is locally weathered to the clay mineral halloysite to depths of about 10 inches (Crandell, 1963). The weathering profile in the Lake Tapps quadrangle probably represents a period of weathering of several tens of thousands of years, for not even rinds have formed on stones in the Vashon Drift, which has been exposed to weathering for about 14,000 years (Waldron and others, 1957; Mullineaux and others, 1965).

\section{DISTRIBUTION AND THICKNESS}

Deposits assigned to the Puyallup(?) are thin and discontinuous and are exposed in only the southwestern part of the mapped area. In the Lake Tapps quadrangle 10 miles south of Auburn, the Puyallup Formation is about 135 feet thick, and its top is at an altitude of 175 feet (Crandell, 1963). It thins and decreases in altitude northward to less than 100 feet in altitude about 1 mile south of the Auburn quadrangle boundary. In the Auburn quadrangle, Puyallup(?) deposits are exposed near flood-plain level at the mouth of the White River valley and intermittently farther north nearly to Kent. A thin ummapped lens of ashy sand, clay, and peat that crops out half a mile southeast of Kent may be the northernmost Puyallup(?) exposed in the mapped area. In the Green River valley, the only deposits continuous enough to be mapped crop out about 6 miles east of Auburn on the south valley wall (Mullineaux, 1965b, c). In the White River valley east of its mouth, the only deposits discovered, near the south boundary of the Auburn quadrangle, are thin and discontinuous and were not mapped.

The maximum known thickness of the Puyallup (?) in the mapped area is about 55 feet, at the mouth of the Green River valley. Fifteen feet of the formation is exposed at that locality, and another 40 feet is known from augering. Along the Green and White River valleys, the formation probably is not more than 25 feet thick.

\section{STRATIGRAPHIG RELATIONS}

The Puyallup(?) Formation conformably overlies intermediate drift and is disconformably overlain by Salmon Springs Drift. Both the upper and lower contacts of the Puyallup(?) are exposed along the Green River valley at section $C$ (fig. 17). There the formation lies conformably on fine-grained till of tha intermediate drift and is overlain and channeled by gravel of the Salmon Springs Drift. In the Duwamish Valley, Puyallup(?) sediments generally extend below flood-plain level. They are overlain and channoled by sand and gravel of Cascade provenance that is mapped as part of the Salmon Springs Drift. Although weathering that probably represents tens of thousands of years and erosional relief of about 100 ) feet occurs on the Puyallup Formation in the Lake Tapps quadrangle (Crandell, 1963), the channeling of the top of the Puyallup (?) is the predominant eridence seen of the time break in the mapped area.

\section{FOSSILS AND ENVIRONMENT}

The Puyallup (?) contains pollen and diatoms that indicate at least part of the formation was deposited during a warm interglacial period. Pollen in a sequence of samples of Puyallup(?) sediments from the Green River valley, studied by E. B. Jeopold, indicate that the climate became as warm as that of the Puget Sound lowland at present. Miss Leopold reported (written commun., 1958) that a provalence of lowland hemlock pollen in the middle of the sequence reflects lowland wet conditions similar to those now in parts of the Puget Sound lowland where rainfall is more than 40 inches annually. A predominance of lowland hemlock over mountain hemlock in this phase of the sequence implies warm growing seasons with an average July temperature of at least $60^{\circ} \mathrm{F}$, as is true of the Puget Sound lowland now. Shifts from dominance of Douglas-fir to lowland hemlock and back to Douglas-fir in the sequence are attributed to changes of rainfall during the depositional interval.

Diatoms from the sequence along the Green River valley, and also from ashy Puyallup (?) beds exposed at the mouth of the White River valley, were examined by Mr. Lohman. Diatoms from both localities are fresh-water forms. Bottom-dwelling types are common at both localities, indicating that the lake or lakes in which they lived were shallow. The Green River valley samples contained a few warm-water and a few cold-water forms, but most are types that liven now in a temperate climate comparable to that of $\mathrm{t} \cdot$ : Puget Sound lowland at present. The White River valley samples contain only types now living in temperate 
or warmer climates. According to Lohman, the diatom assemblage from each locality indicates interglacial, temperate conditions as warm as those in the Puget Sound lowland now.

Puyallup (?) sediments exposed along the Duwamish Valley are chiefly alluvium similar to that now being deposited on the Duwamish Valley floor, and they include water-laid ash and a volcanic mudflow. These deposits probably were laid down on the wide flood plain of a river that headed on Mount Rainier. Puyallup(?) deposits exposed along the Green River valley are thin, lenticular, and characterized by at least partly lacustrine sediments that were slowly accumulated. They probably were laid down on an undulating interfluvial plain of intermediate drift very like the surface of the Vashon drift plain of the present. Beds of volcanic ash in all the deposits show that a volcano, presumably Mount Rainier, was active during Puyal$\operatorname{lup}(?)$ time.

\section{SALMON SPRINGS DRIFT}

Stony till and outwash sand and gravel assigned to the Salmon Springs Drift overlie Puyallup(?) deposits and underlie Vashon Drift along the Green River, White River, and Duwamish Valleys. Along the Duwamish Valley walls, these deposits can be traced into the type Salmon Springs Drift in the Lake Tapps quadrangle. The Salmon Springs Drift is named for springs on the east wall of the Duwamish Valley about 6 miles south of Auburn (Crandell and others, 1958).

Fluvial sand and gravel of Cascade provenance locally underlies and overlies Salmon Springs outwash gravel and locally is interbedded with northern outwash along the Duwamish Valley wall near Auburn. These Cascade-derived sediments are closely associated with and are similar in grain size to the Salmon Springs stratified drift, and they are mapped and described as part of the Salmon Springs deposits.

\section{LITHOLOGY}

The Salmon Springs Drift consists chiefly of fluvial sand and gravel. The formation locally includes one or two till layers, and in places its lowermost and uppermost beds are fluvial sand and gravel mainly of Cascade provenance. The formation is well exposed in northeast Auburn in the Duwamish and Green River valley walls. There, the formation consists of thick sand and gravel of Cascade or mixed Cascade and northern provenance at the base; this sand and gravel is overlain by northern sand and gravel that includes two layers of till, which in turn is overlain by sand and gravel of Cascade provenance (section $E$, fig. 18).
Section E. Composite section in center sec. 17, T. 21 N., R. 5 E., in Green River and Duwamish Valley walls

Vashon Drift:

Sand and pebble gravel, gray to light-brown, friable

Till, stony, gray (sample 845-16-6)

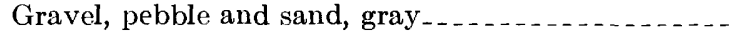
Salmon Springs Drift:

Sand and pebble gravel, reddish-gray to gray; Mount Rainier provenance..................... $>20$

Sand and gravel, olive-gray to brown; northern provenance. . . .

Till, stony, olive- to brownish-gray (sample 84516-5)

Sand and pebble gravel, brown; northern provenance

Till, stony, olive- to brownish-gray ............ _. . . 5-10

Sand and gravel, brown; northern provenance _.... 5-10

Gravel, pebble-and-cobble, and pale-yellowishbrown to brown sand; Cascade or mixed Cascade and northern provenance; grades into overlying northern sand and gravel. . ...............

Silt and clay, peaty; contains scattered stones.......

Gravel, pebble-and-cobble, and pale-yellowish-brown, light-brown, and brownish-gray sand; Cascade or mixed Cascade and northern provenance .........

Sand and silt, blusish-gray to reddjsh-brown; contains wood and peat.

Sand and pebble gravel, reddish-brown ........... Puyallup(?) Formation:

Silt and sand, peaty, reddish-gray to brown; Mount Rainier provenance....... 5-10

Mudflow, hard, compact stony silt and sand........ $\quad>5$

Till is common in the formation only in the vicinity of Auburn, where at least two separate layers are exposed. From section $E$, till is intermittently exposed northward for about 3 miles in the Duwamish Valley wall. It is also exposed eastward from the Duwamish Valley wall for about a quarter of a mile in the Green River valley wall. In the White River valley, till is exposed intermittently from the south boundary of the quadrangle northwestward for about a mile and a $\mathrm{r}$ alf. Elsewhere along Duwamish Valley and the valleys of the Green and White Rivers, however, till was found either sparsely or not at all.

The till generally is olive gray to yellowish brown, hard and compact, and unsorted and unstratified. It consists of numerous stones in a silty sand matrix; the stones and heavy minerals indicate a northern provenance. The till is similar in texture and composition to Vashon till and is distinctly more stony than typical tills of the underlying intermediate drift (figs. 15, 16).

Stratified drift from the Puget lobe at section $E$ is mostly brown sandy gravel and coarse sand. It is loose and well sorted in a few places, but generally it is compact and has a matrix of grayish-yellow silt and clay. 


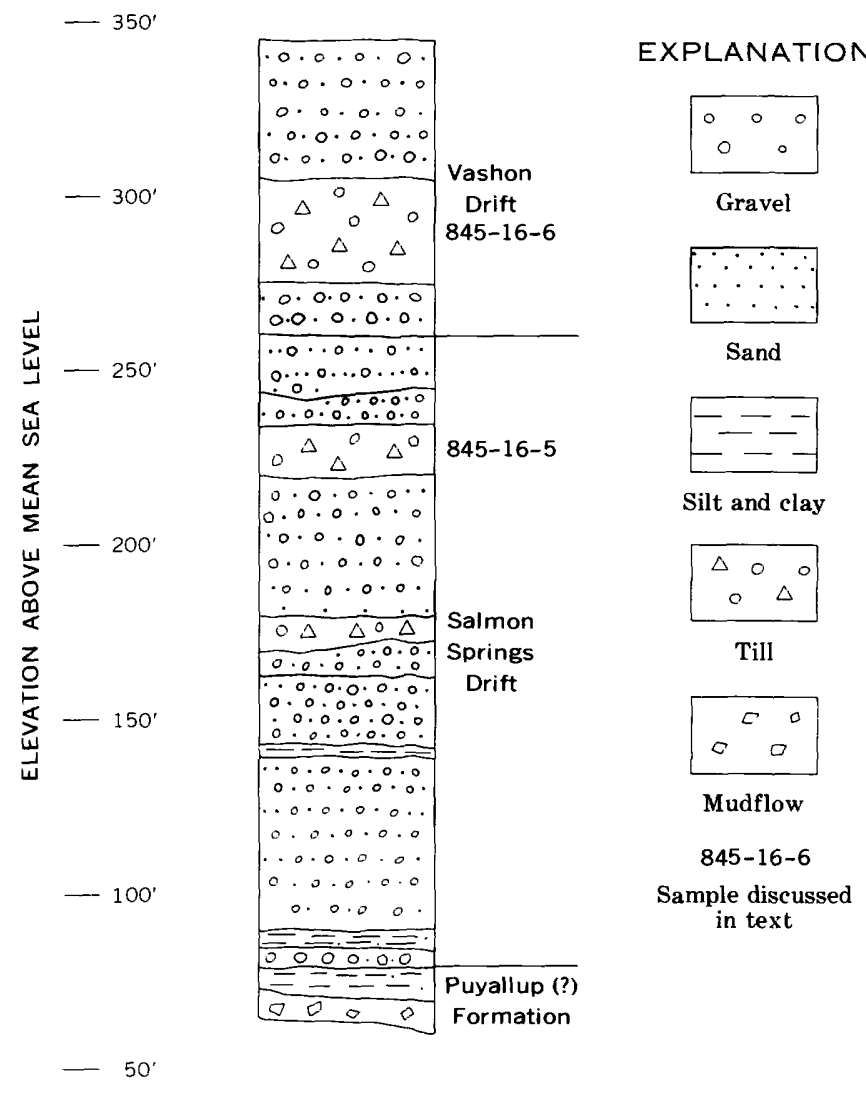

Figure 18.- Sketch of section $E$, showing Salmon Springs Drift. Section $E$ is in center sec. 17, T. 21 N., R. 5 E.

A few fragments of wood have been found in it between the two tills. Cascade-derived fluvial sediments and those of mixed Cascade and northern origin are sandy pebble-and-cobble gravel that contains lenses of sand and even of clayey silt. Most of this fluvial detritus is of central Cascade origin, but pebbles derived from Mount Rainier are common, and several lenses of sand are largely of Mount Rainier provenance. Peat and flattened wood fragments are common in clayey silt and sand near the base of the Salmon Springs sequence at section $E$, and organic material occurs sparsely in a lens of clayey silt about 55 feet higher. Pollen samples from these organic sediments, analyzed by Miss Leopold, are dominated by pine and spruce; the pollen are suggestive of but not diagnostic of a cool climate.

Salmon Springs stratified sediments along Duwamish Valley north and south of Auburn appear to be mostly interbedded gravels and sands similar to those at section $E$. Stratified drift exposed in the Green and White River valleys is chiefly brown sand and pebble-and-cobble gravel.

\section{WEATHERING}

The Salmon Springs Drift is somewhat iron stained, and a few stones in it are decomposed. Stratified sediments, even those along Duwamish Valloy that have a silt and clay matrix, generally are stained yellowish brown. Although some deposits in the Salmon Springs are gray and appear fresh, iron staining is widespread enough to be useful in differertiating Salmon Springs from Vashon Drift. The staining suggests that the Salmon Springs Drift was weathered before Vashon time, but no weathering profile has been found on it.

\section{DISTRIBUTION AND THICKNESS}

Salmon Springs Drift is inferred to compose most of the east wall of Duwamish Valley from Kent to the south boundary of the Auburn quadrangle, where it extends on into the Lake Tapps quadrangle. At section

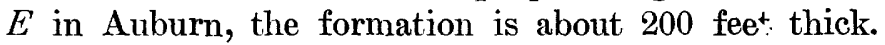
Near the south boundary of the Auburn quadrangle, it is intermittently exposed from near flood-plain level up to about 450 feet above sea level; thus it must, be at least 400 feet thick in that vicinity. It also crops out for several miles in the Green and White River valleys upstream from Auburn. In the Green River valley, it generally is less than 100 feet thick; and in the White River valley, it is less than 50 feet thick.

\section{STRATIGRAPHIC RELATIONS}

The Salmon Springs Drift lies unconformably on the Puyallup (?) Formation or the intermediate drift and is unconformably overlain by Vashon Drift. The base of the Salmon Springs is exposed at sections $C$ and $E$, where the formation lies in channels cut into the underlying Puyallup(?) and intermediate drift formations. The base of the Salmon Springs is more than a hundred feet lower along Duwamish Valley than it is along the Green and White River valleys a few miles to the east. A north-trending valley, whose east wall was a short distance east of Auburn, may have been filled by Salmon Springs Drift.

Along the Green River valley east of Auburn, brown Salmon Springs Drift locally is overlain by gray gravel and stony till that underlie Vash on till. This gray drift has been mapped as part of the Salmon Springs, though it may be younger.

\section{UNDIFFERENTIATED DRIFT IN THE CEDAR RIVER VALLEY}

Several layers of till and intervening stratified sediments including peat underlie the Vashon Drift along the Cedar River east of Renton. In this stratigraphic 
sequence, no till layers were found with markedly different textural or weathering characteristics, comparable to, for example, the fine-grained tills in intermediate drift or the weathered Orting(?). Neither were distinctive sediments from Mount Rainier found anywhere to serve as marker layers. Consequently, no stratigraphic sequence similar to that in the Green River valley and in Duwamish Valley was recognized. Because the Cedar River valley strata could not be traced to the other valleys, they are not correlated with or described as part of the named formations mapped farther south. Not only were no distinctive marker layers recognized in the Cedar River valley sequence, but analyses of pollen layers from three different horizons in the sequence failed to show evidence of a distinctly warm climate separating episodes of till deposition. As a result, the entire sequence has been mapped as and will be described as undifferentiated.

\section{LITHOLOGY}

At least three layers of pre-Vashon till, separated by fluvial sand and gravel and lacustrine sand of predominantly northern provenance and by silt and clay, are exposed in the Cedar River valley walls. The stratigraphy of these deposits is illustrated by sections $F, G$, and $H$, in figure 19 . Composite section $F$ at Renton includes at least three, and perhaps four, layers of pre-Vashon till. Two of the layers are exposed nearly as far east as the quadrangle boundary. Each of the layers that clearly is till is gray and not noticeably oxidized; the one other layer that may be till, which directly overlies a woody silt and peat deposit, is grayish brown.

The pre-Vashon tills of the Cedar River valley area are generally similar in texture and composition to the Vashon till and were deposited by the Puget lobe. Overall, they are somewhat finer grained than Vashon till, but they are not as fine grained, nor do they show the fractures typical of till in the intermediate drift.

The prevalent stratified deposits along the Cedar River valley are sand. Uniform horizontally bedded lacustrine sand with silt and clay is widespread and as much as 100 feet thick in exposures on the north side of the valley (fig. 19). Probable lacustrine sand at the base of section $H$ is of central Cascade provenance and is nonglacial. Till and varved clay and silt at higher altitudes, however, show that a considerable part of the sequence is glacial. Fluvial deposits include sand, pebble gravel, and locally boulder gravel. One bouldery cobble gravel 15-20 feet thick occurs in channels at the top of thick lacustrine deposits at sections $G$ and $H$ (fig. 19).

\section{WEATHERING}

The drift along the Cedar River valley shows little weathering other than partial iron oxide staining of permeable sediments. Tills, with the possible exception of one, are not notably more oxidized than the Vas ' on till. Near Renton, iron staining generally is limited to a few beds, and even some very coarse and permeable gravels are not stained. However, farther east, the staining is more intense and more widespread. Part of the more strongly stained deposits in the eastern rart of the quadrangle may be equivalent to unstained strata nearer Renton, but the basal strata to the east certainly underlie the beds exposed at Renton. No weathering profiles have been found either within or on top of the undifferentiated drift in the Cedar River valley.

\section{DISTRIBUTION AND THICKNESS}

Pre-Vashon drift makes up most of the Cedar River valley walls from Renton eastward to the quadrargle boundary. The deposits dip as much as 350 feet per mile to the northwest, thus progressively older strata are exposed upvalley. The pre-Vashon beds are nore than 200 feet thick about 3 miles east of Renton. TJnoxidized drift like that in the Cedar River valley also crops out in a few places along Duwamish Valley in and slightly south of Renton.

\section{FOSSILS AND ENVIRONMENT}

The undifferentiated deposits include peat in t.wo, and probably three, stratigraphic horizons. The warmest climate indicated by pollen in several samples f.om the peat beds is definitely cooler than the present climate in the Puget Sound lowland. Pollen has been examined from peat at the top of the pre-Vashon sequence at section $H$ and across the valley from section $F$, and from peat at $75-90$ feet above sea level at section $F$. According to Miss Leopold, pollen from section $H$ indicates that the climate was cool, similar to that which now characterizes altitudes of 4,000-5,000 feet on the west flank of the Cascade Range in Washington. Pollen from peat across the valley from section $F$ is almost entirely pine, so no climatic interpretation can be made. Pollen from section $F$ is largely comparable to pollen in modern peat at altitudes of $3,000-$ 4,000 feet in the Cascade Range. The assemblage contains a few species typical of the present Puget Sound lowland, however, which may indicate the climate was somewhat warmer than that now at 3,000-4,000 frat.

\section{VASHON DRIFT}

Till or stratified drift of Vashon age lies at the surface of the drift plain in almost all of the area mapned. The name Vashon was first used by Willis (1898c, p. 


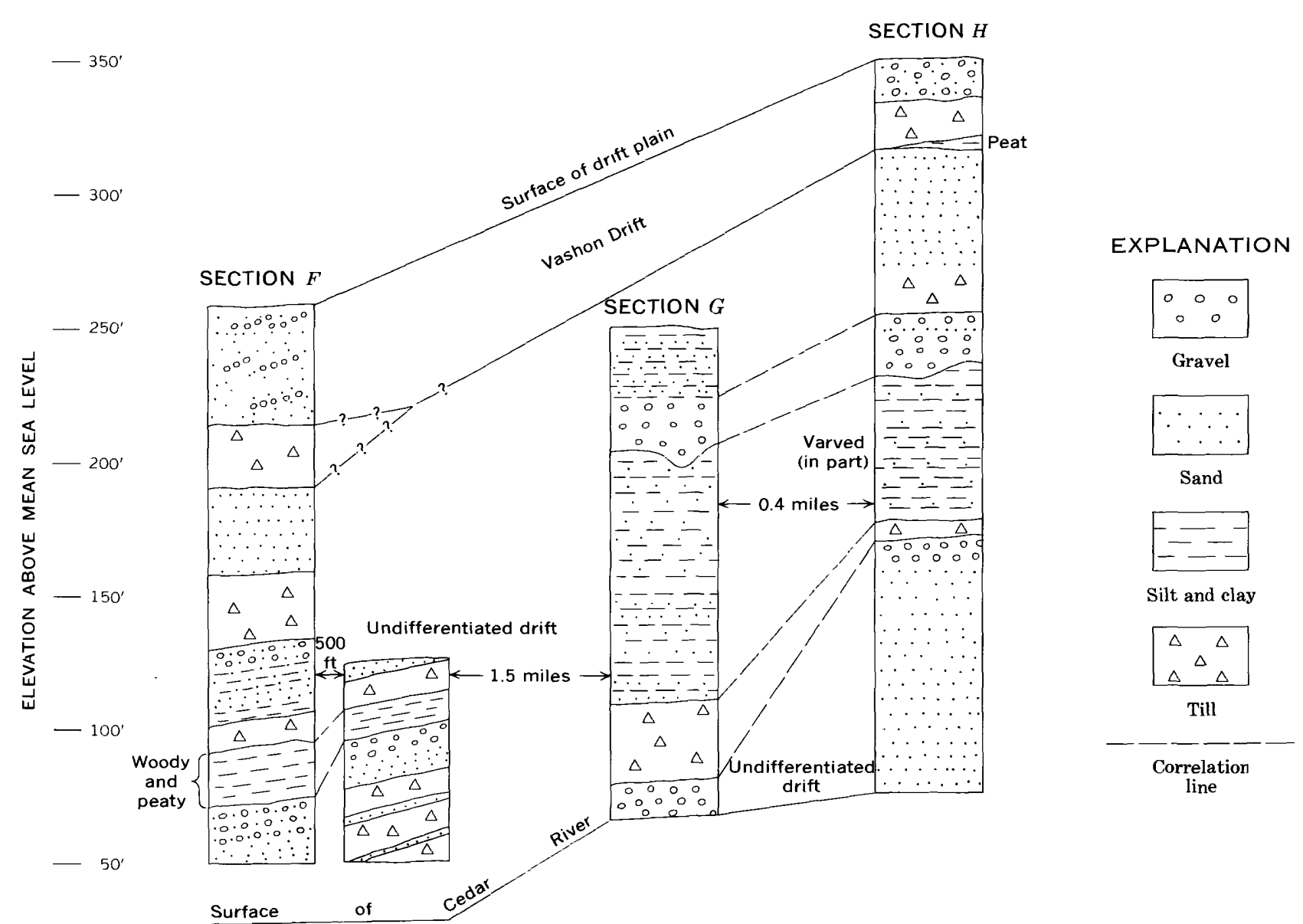

- SEA LEVEL

Figure 19. - Sketch of sections of undifferentiated drift exposed on the north side of the Cedar River valley near

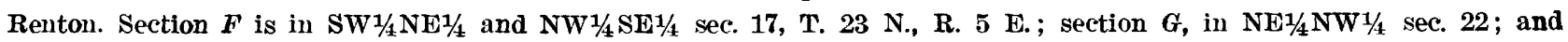
section $H$, in NE $1 / 4$ NE $1 / 4$ sec. 22 , T. 23 N., R. 5 E.

126) for "the episode represented by the latest occupation of the Puget Sound basin by the northern ice tongue and its deposits." The term is derived from Vashon Island in Puget Sound southwest of Seattle, where according to Willis (1898c, p. 126), characteristic gravelly till occurs "typically, although not heavily." The Vashon Drift as used by Willis is still called Vashon Drift, but his Vashon Glaciation is now known as the Vashon Stade of the Fraser Glaciation (Armstrong and others, 1965).

The Vashon Drift extends entirely across the mapped area, and as much as 25 miles farther south (Bretz, 1913; Crandell, 1963). 'Twelve miles east of Renton, the glacier rose to a height of about 3,000 feet on Tiger Mountain (also known as Mount Issaquah) (Bretz, 1913, p. 36; Vine, 1969). In the Lake Tapps quad- rangle south of Black Diamond, the glacier rose to altitudes of 1,600-1,800 feet along the Cascade mountain front (Crandell, 1963). Thus the ice probably was at least 2,500 feet thick over the drift-plain surface near Renton, and at least 1,500 feet thick over that surface even in the southernmost part of the mapped area.

\section{TILL}

Vashon till forms the present surface of about half the drift plain, and probably extends under most other deposits that lie at the surface. It is the most widely exposed unit in the mapped area. In thickness, it is highly variable; the maximum exposed is about 70 feet, but the average thickness probably is no more than 20 feet, and exposures in which it is less than 5 feet thick are common. It is generally thinner on north-facing 
than on comparably steep south-facing slopes. Locally, the Vashon Drift appears to contain two layers or zones of lodgment till, but in most places it contains only a single layer.

\section{TOPOGRAPHIC EXPRESSION}

Vashon till mantles rather than forms major topographic units. It veneers almost all the drift plain (though it is covered itself in places), and it laps up over bedrock highlands as well as over some valley walls, such as those in Duwamish Valley. On a minor scale, however, the Vashon till forms the characteristic topography of undulating ground moraine. On that scale, the ground moraine has a rolling surface that is characterized by a relief of a few tens of feet and by numerous closed depressions. On a larger scale, the surface displays a rough south to south-southeast elongation of hills and swales; locally, the hills are very elongate, cigar shaped, and closely alined in drumlinized topography. Such an alinement is formed by actively flowing ice (Flint, 1957, p. 72) and indicates the direction of ice movement. Most of the hills in the drumlinized ground moraine appear to be only reneered by till, but some small hills probably are drumlins constructed entirely of Vashon till. The relief and alinement probably result from scour and fill by the glacier.

The surface of the till has been very little modified except where it has been eroded by large melt-water rivers on the drift plain and by postglacial rivers that have cut valleys down through it. On most of the ground moraine, postglacial change has been limited to minor erosion by small streams.

\section{LITHOLOGY}

Vashon till consists of an unstratified, nearly unsorted mixture of pebbles and cobbles in a clayey silt and sand matrix (figs. 15, 16), and it contains scattered boulders as large as several feet across. Till that is often regarded as typical is compact, hard, and coherent. Silt and clay particles are tightly packed into spaces between grains of sand and gravel, and as a result the till is highly impermeable. This tight, dense till is regarded as lodgment till, deposited at the base of and compacted by the weight of the glacier. It generally is the "hardpan" of local well drillers and construction workers. A second facies can be recognized almost everywhere the till lies at the surface. This facies is less compact, less coherent, locally somewhat sorted, and usually only a few feet thick. The looser material probably is chiefly ablation till, let down from the surface of the glacier as the ice melted, and is not appreciably compressed by ice. The less compact material may also include some lodgment till that has been loosened by frost, root, and animal action. Locally, it grades into thin stratified drift.

Although the till is unstratified, it does contain some blocks and lenses of stratified drift. In addition, lodgment till commonly shows thin partings, close to and approximately parallel to the ground surface; the resulting structure is called fissility by Flint (1957, p. 113). In places, Vashon till also shows horizonts.l or gently dipping partings that are spaced several feet apart.

The till everywhere in the mapped area is a mixture that is characterized by a substantial amount of matelial in each of many size grades (fig. 16). It differs significantly in average grain size and in degres of sorting, however, from place to place in the mapped area. Just north of the Cedar River, for example, the till consists mostly of silty sand. Over most of the rest of the area, however, as Willis (1898c) noted, it typically is gravelly. Most of the pebbles and cobbles are rounded rather than angular, and only a few are strongly faceted or striated. The rounding of the stones probably resulted from a pre-Vashon history of stream abrasion, and perhaps short transport by the Vashon Puget lobe. Most constituent pebbles, though their ultimate source was the mountains of Washington, probably were transported first by rivers into the part of the lowland north of the mapped area. These stones, rounded by rolling along streambeds, were later pisked up by the Puget lobe and incorporated into its deposits.

Generally about 5-15 percent of the rocks and minerals in Vashon till can be identified as of northern provenance, but the rest are of Cascade or of doulstful origin. Locally, especially in till just south of Puget Group outcrops near Renton, the till also contains abundant fragments of soft sandstone and shale. Garnet commonly makes up at least 5 percent of the sandsize heavy-mineral grains. Clay-size particles, smaller than $2 \mu$ (microns), are approximately half nor clay minerals and half clay minerals; the clay minerals are mostly montmorillonite and chlorite (table 4).

\section{WEATHERING}

Weathering generally is limited to oxidation in the upper few feet and to development of a weak brown podzolic soil profile (Poulson and others, 1952; C andell, 1963). Where the ablation till is more than 3 feet thick, oxidation commonly extends to a depth of about 30-36 inches. In relatively permeable ablation till, it may extend a foot or two deeper. Where the ablation till is only a foot or two thick, the oxidized zone extends down through it and a few inches beyond into 
compact lodgment till. A thin rim of accretionary iron oxide occurs on stones within the oxidized zone; but lower in the till, iron oxide is generally not concentrated around stones or along fractures.

\section{ADVANCE STRATIFIED DRIFT}

Advance stratified drift occurs in all parts of the mapped area but generally is thin and discontinuous and covered by Vashon till. The advance deposits are especially well exposed along the major river valleys that were cut in postglacial time. Advance drift is similar in texture and composition to recessional stratified deposits and in general can be distinguished from recessional drift only where it is overlain by Vashon till. A few deposits, however, can be recognized as probable advance drift, because their surfaces apparently have been modeled by overriding ice.

Advance drift locally fills depressions in the preVashon topography and is highly variable in thickness. The thickest exposed deposits crop out along Big Soos Creek and Duwamish Valley, where they locally are more than 100 feet thick. However, advance drift generally is less than 50 feet thick and probably averages less than 30 feet in thickness. The variations from place to place suggest a few features of the pre-Vashon topography, but exposures are not adequate to outline the older drainage pattern. Thin widespread sand and gravel under Vashon till along the Cedar, Green, and White River valleys suggests that the pre-Vashon drift plain in those areas was broad and similar to the present one. Thick deposits that suggest former deep valleys are sparse; at only two sites, along the Big Soos Creek and Duwamish Valleys, do advance sediments show the existence of depressions of 100 feet or more in the pre-Vashon surface. Thus neither an extensive nor a deep pre-Vashon valley system is indicated by the exposed advance stratified drift.

Advance sediments consist chiefly of gray unoxidized pebble-and-cobble gravel and pebbly sand. The gravel is typically compact and indistinctly stratified, and in places it contains substantial amounts of interstitial silt and clay. Although such a matrix is not universal in the mapped area, it appears to be more common in advance gravels than in recessional deposits. Sand is also common in the advance drift, which locally also includes lenses of silt and clay. No oxidized zone characterizes the top of the advance drift, because it was immediately covered by Vashon till. Brown, oxidized layers, however, are present within it in a few localities.

\section{RECESSIONAL STRATIFIED DRIFT}

Stratified drift laid down as the glacier retreated is composed of a wide variety of deposits, which are divided into two groups on the basis of inferred origin. One group consists of small deposits laid down by melt-water streams that probably issued directly from the nearby ice front. These are the generally small and discontinuous bodies of recessional outwash that lie in the Renton quadrangle and in the part of the Auburn quadrangle that is northwest of the Covington channel. The second group, representing a much larger volume of sediments, was deposited by a large icemarginal river that originated not locally but much farther north along the Puget lobe. This river flowed southward along the east flank of the lobe to the ice front, then southwestward along the front and across the mapped area. It included, besides Puget lob: melt water, considerable drainage from the Cascade Range, which flowed west to the Puget lobe and joined the ice-marginal stream flowing along the flank. The icemarginal river laid down broad, continuous deposits over much of the Black Diamond quadrangle, along the Covington channel, and, to a lesser extent, along the Cedar River valley.

\section{DEPOSITS OF LOCALLY DERIVED MELT WATER}

Recessional stratified drift deposited by melt water from the local ice front consists of scattered kames and small valley trains on the drift plain, and kame terraces and glaciolacustrine deposits along tho $\mathrm{Du}$ wamish Valley.

\section{Kame Deposits}

The kames are few in number and widely separated. The largest is a low ridge of sand about 1 milo long but less than a quarter of a mile wide that is located about 1 mile east of Kent. Four other kamos are mapped on the drift plain between Renton anc Lake Youngs south of the Cedar River (Mullineaux, 1965a); all consist chiefly of pebbly sand. A single small kame in the northeast corner of the A.uburn quadrangle consists of sandy pebble-and-cobble gravel.

\section{Valley-Train Deposits}

Small valley trains, composed chiefly of sand and pebble gravel, were formed in some shallow troughs that led from the ice front southward over the drift plain. The valley-train deposits are terrace remnants and collapsed masses of sand and gravel, mostly in the trough of Big Soos Creek and in a trough betweon the Cedar River valley and Lake Youngs. The deposits indicate that irregular masses of stagnant ice lay in parts of these depressions during formation of the valley trains. Melting of the ice resulted in collapse of parts of these deposits and destruction of their constructional surfaces. Recent peat and alluvium now cover some of the collapsed sediments. 
The least collapsed valley-train deposit probably records a temporary stillstand of the ice front in the shallow trough of the drift plain in which Big Soos Creek now flows. The deposit forms a continuous pair of terraces in the trough from the Covington channel northward for about a mile and a half. For the next 2 miles farther north, however, deposits at the surface along the creek are chiefly lacustrine silt, clay, and peat. Ice apparently filled the part of the trough now floored by lacustrine sediments while the valley train leading to the Covington channel was deposited. The ice then retreated rapidly from that position, and silt and clay were laid down in a temporary lake formed in the trough behind the valley-train deposits.

\section{Kame-Terrace Deposits}

Many small kame terraces were formed along Duwamish Valley north of Auburn, adjacent to a tongue of ice that lay in the Duwamish Valley after the glacier had retreated from the drift plain. Streams from the drift plain descended to the ice margin, and there joined melt water flowing between the valley wall and the ice. Deposits of these streams include some relatively undisturbed cut-and-fill terraces and some extensively collapsed fill terraces.

Directly east of Auburn, two kame terraces cover about a quarter of a section each in secs. 8, 9, and 17 . They are high on the valley wall, at about 350 feet above sea level, and may have been formed while the Puget lobe still covered part of the drift plain nearby. Both appear to be composed of well-sorted gravelly sand and pebble gravel from about 15 to 40 feet thick.

In Kent, several small terraces were cut across a spur on the Duwamish Valley wall while ice in the valley served as the northwest bank of a channel. The sand and pebble gravel that underlies these terraces probably is only about $10-20$ feet thick.

Several kame-terrace deposits that collapsed extensively are located along the valley wall north of Kent. The highest and largest of these, composed of well-sorted sand and pebbly sand, is about a mile and a half northeast of Kent. Collapsed deposits on the valley wall below the high terrace generally consist of less well sorted material, and near the valley floor they grade into mixtures of clayey sand and bouldery gravel that may represent lateral moraines. The "moraines" and some of the adjacent extensively collapsed kameterrace deposits have been mapped together as undifferentiated Vashon Drift (Mullineaux, 1965a).

\section{Lagustrine Deposits}

Two lacustrine sand and silt deposits crop out in Renton. These were laid down in a lake in Duwamish
Valley that stood at least 25 feet above the level of the present flood plain. One deposit is a fan-shaped bc dy at the mouth of a small stream south of the businiss district of Renton. It grades from pebbly sand near its apex to clayey silt and sand at its distal edge. The second is a mass of horizontally bedded sand and silt exposed in sec. 18, from about 20 to 40 feet above sea level. Although these deposits were laid down ir. a lake ponded by the Puget lobe, they are free of kettles or any other evidence that they were deposited against ice.

\section{DEPOSITS OF THE ICE-MARGINAL RIVER}

A large ice-marginal river, fed by melt water is`uing directly from the east flank of the Puget lobe, by large and small streams draining the adjacent Cascade Range, and by combined melt water and Cascade drainage from farther north by way of the Cedar Spillway of Mackin (1941, p. 465; see fig. 22, this report), formed along the east flank of the Puget lobe during the retreat of the lobe. The river occupied many successively lower and more northerly channels as the ice retreated across the lowland southeast of Seattle (Bretz, 1913; Crandell, 1963). Owing to variation of the overall slope of the drift plain in the mapped area, the melt-water river occupied many closely spaced, poorly defined channels southeast of the Covington channel but crossed the northwestern part of the mapped area only along the route of the present Cedar River. The part of the drift plain southeast of Covington decreases in overall altitude to the northwest to a broad shallow sag that trends northeast from Auburn. Farther northwest, the overall altitude of the drift plain increases again. As the Puget lobe retreated north and northwest, the ice-marginal river occupied successively lower, southwest-trending courses, mortly along the ice front but locally over ice, until it reached the broad sag. The glacier continued its northwestw $>$ rd retreat, but the river remained in the sag, which became the Covington channel, until it shifted to the position of the Cedar River.

Large volumes of stratified drift were deposited by the ice-marginal river in kames, a broad pitted critwash plain, valley trains, a kame terrace, and a delta. Although some of the sediments were laid down in contact with ice, they are almost entirely channel deposits of a large river. Consequently, they are typicslly coarse, well sorted, and well stratified.

\section{Kame Deposits}

The kames are irregularly shaped mounds of str?tified drift that owe their shape to collapse caused by melting of underlying or adjacent ice. They occur in 
three groups or fields in the Black Diamond quadrangle. Each field is characterized by the hummocky shape of mounds and intermound depressions that is called kame-and-kettle topography. Two of the kame fields grade, by decrease in proportion of collapsed surface, into the adjacent pitted outwash plain. Because of their formation adjacent to or on ice, these kame deposits are more variable in texture and structure than most other outwash deposits. Horizontal continuity of individual strata locally is limited, and beds of markedly different grain size are interbedded. Scattered boulders are common, and, locally, sorting is poor. Thickness is highly variable from place to place in the kame deposits; a minimum thickness can be estimated from the height of the kames.

The largest of the three kame fields, about 2 square miles, is south of the Green River, in the southeast corner of the quadrangle. It is partly covered by the Osceola Mudflow, and one kame is separated at the surface from the remainder of the field by lacustrine and terrace deposits. Apparently, pebbly medium to coarse sand predominates in the southern and western parts of this field, and pebble-and-cobble gravel in the northern part. A smaller field, composed chiefly of pebbly sand, covers about half a square mile just west of the town of Black Diamond. A third, poorly defined kame field, which grades into the surrounding outwash plain on all sides, lies 4 miles farther west, mostly in sec. 18 , T. 21 N., R. 6 E. Kames in this field probably consist largely of pebble-and-cobble gravel, but they also include medium and coarse sand.

\section{Outwash-Plain Deposits}

Pitted outwash terraces and channels that form a broad low-relief surface over much of the Black Diamond quadrangle are mapped together as an outwash plain. Locally, topographic units of that plain are well defined, but over most of the plain they are indistinct or discontinuous. Furthermore, surfaces that formed during a single stream-flow regime - even those that can be traced southwestward in the direction of floware commonly now preserved as terraces at one place and channel floors at another. The drift-plain surface itself decreases gradually in altitude to the southwest along these channels and terraces. It also decreases in altitude to the northwest, by steps, from one set of surfaces to the next. In places, scarps-separating the steps are several tens of feet high and are sharp and long. More commonly, however, they are low, indistinct, and laterally discontinuous.

Outwash-plain gravel occurs in about half the Black Diamond quadrangle. It is prevalent at the surface from the Covington channel to the Green River, sur- rounding nearly all the hills of ground moraine and kame deposits. It also extends southward beyond the quadrangle boundaries, but south of the Green River it is covered by the Osceola Mudflow. Deep kettles and high scarps show that the gravel locally is more than 50 feet thick and commonly is more than 20 fee $^{+}$thick. Gravel-pit exposures in an area west of Lake Sawyer, however, show that the gravel there, at least loally, is only 10-20 feet thick. Gravel of similar thickness underlies a wide terrace in sec. 1, T. 21 N., R. 5 E.

Well-sorted and stratified pebble-and-cobble gravel make up most of the upper 10-20 feet of the oxtwashplain deposits, though pebbly sand and bouldery cobble gravel are locally present. Below the upper 10-20 feet, there appears to be a greater variation in grain size. The lower deposits may represent, at least in part, kame or kame-terrace deposits of which the upper part was reworked later by the ice-marginal river.

Most of the outwash-plain sand and gravel was deposited as the ice-marginal river ran in a chute which had been formed between the glacier front and the sloping drift plain. On the northwest, the river channels were bounded partly by ice and partly by groundmoraine hills. The highest terrace gravels in tho southeastern part of the outwash plain were deposited first. When they were laid down, the site of the northwestern part of the outwash plain was still largely covered by ice. Frequent small changes in the positior of the ice front allowed concurrent small shifts of the river into successive channels, each of which was only slightly lower and farther northwest than the previous one. Such frequent shifts could account for the many closely spaced channels and terraces, which difer only slightly in altitude, that characterize the outwash plain.

\section{Valley-Train Deposits}

Valley trains were formed along the Covington channel as higher ground to the northwest prevented continuation of progressive northward shifting of the ice-marginal river. The principal valley train ranges in width from about half a mile to 2 miles and lies in the Covington channel from Maple Valley southwest to Duwamish Valley at Auburn. Terraces along the channel suggest that the melt-water river first formed a gravel fill at high level. It then cut into the fill, pausing enough during the cutting to form other broad flood plains at levels below the fill surface. Tho upper fill terraces appear to consist of pebble-and-cobble gravel' as much as 50 feet thick. At lower lerels, cut terraces consist mostly of pebble gravel that probably is only 10-20 feet thick. In the northeastern part, of the channel, the channel floor is covered with sand. The 
sand, by its size, records a decrease in carrying capacity of the ice-marginal river and probably was laid down after part and perhaps most of the river had shifted its flow to a channel farther north.

Formation of the valley-train fill resulted in the blocking of some small tributary valleys along the Covington channel. Foresets in valley-train gravel, exposed in borrow pits in the SE. cor. sec. 26 and in the NE. cor. sec. 35, T. 22 N., R. 5 E., dip across and up the Big Soos Creek valley, suggesting that the gravel at least partly blocked the trough of Big Soos Creek. In secs. 3 and 10, T. 21 N., R. 5 E. the valleytrain surface slopes from the Covington channel across and slightly up another small tributary valley. Grain size of the valley-train deposit decreases up the tributary valley, from pebble-and-cobble gravel in the main channel to sand half a mile to the north. Farther north, lacustrine sediments were laid down behind the dam of sand and gravel. Silt and clay more than 18 feet thick were penetrated by augering in a branch of the tributary near the center of sec. 34 , T. 22 N., R. 5 E.

Kame-Terrace Deposits

One large kame terrace was formed by the icemarginal river in an embayment of Duwamish Valley wall in secs. $28,29,32$, and 33, T. 21 N., R. 5 E. The kame terrace has been partly eroded by the White River, but it still covers about 1 square mile on the south side of the White River valley. Gravel is exposed intermittently from the level of the White River, which is less than 125 feet above sea level, up to about 425 feet in the valley wall. Gravel and sand nearly 200 feet thick crop out in a single exposure in the western part of the terrace. The terrace deposits are largely wellsorted and stratified pebble-and-cobble gravel, with lesser amounts of sand. In the westernmost, extensively collapsed, part of the terrace, however, the prevalent material at the surface is well-sorted medium and coarse sand.

\section{Delta}

The Auburn delta (Bretz, 1913, p. 134) was built into an ice-dammed and partly ice-filled lake in $\mathrm{Du}$ wamish Valley at Auburn at the end of the Covington channel. At least one large iceblock was buried in the delta; melting of the iceblock formed the kettle now occupied by White Lake. Gravel of the Auburn delta forms most of the wall of Duwamish Valley between the Green and White Rivers. The gravel crops out for about a mile and a half in a north-south direction but extends, as a thick deposit, only about a quarter of a mile east of the delta face. The part of the delta west of White Lake stands about 150 feet above the adjacent
Duwamish Valley floor, and gravel is exposed from the top to the level of the valley floor. Thus, the gravel. is at least 150 feet thick. Furthermore, because the floor of the Duwamish trough was several hundred feet lower during late glacial time than it is now, the deposit probably extends several hundred feet fartlior down the old valley wall and is now buried by alluvium. The surface of the delta east of the White Lake kettle merges smoothly with the surface of the valleytrain deposits of the Covington channel.

The delta gravel is chiefly well-sorted, well-stratif $\circ$ d pebble-and-cobble gravel. Topset and foreset beds are well exposed in a gravel-pit wall nearly 125 feet high southwest of White Lake. The topset beds are about 20 feet thick, and long unbroken foreset beds make up the rest of the exposed deposit. Similar foreset beds ware exposed in 1959 along a railroad spur west of White Lake and along the railroad and highway north of the lake. In the high pit wall southwest of the lake, the foreset beds dip west; northward their dip swings progressively more toward the north so that in the northernmost exposure along the delta face the dif is northwest. Topset and long foreset beds were also woll exposed in 1959 in a gravel pit in the southwesternmost part of the delta.

The principal surface of the delta terminates alcng its west margin at altitudes of slightly more than 250 feet. Bretz (1913) recognized a 260 -foot level as woll as a level at 235 feet, and he proposed that the Auburn delta was deposited in an arm of Lake Tacoma. Lake Tacoma, according to Bretz (1913, p. 133, 134), occupied the Duwamish and Puyallup troughs south of Auburn and spilled through a channel in Sorth Tacoma.

\section{AGE AND GORRELATION OF PLEISTOCENE DEPOS'TS}

Although at least four episodes of glaciation are recorded by the Pleistocene deposits, only the youngest drift, the Vashon, can be dated closely or correlated with confidence with Pleistocene deposits outside the lowland. The Vashon can be dated the most accurately because it is young enough to fall within the range of radiocarbon dating methods used to measure ages back to about 38,000 years. Recognized pre-Vashon formations in the mapped area, in contrast, are all older tl an 38,000 years. The age of these older formations is estimated on the basis of the number of events that separate them from the Vashon, and the probable timespans of the events. Estimates of time spans, in turn, are based on such factors as overall weathering or existence of weathering profiles, periods of erosinn, and evidence of significant changes of climate. 
The Vashon Drift was deposited during the Fraser Glaciation (Armstrong and others, 1965); the Vashon was the only stade of that glaciation in which the Puget lobe extended into the southeastern part of the lowland. The Vashon Drift has been most closely dated at Seattle. A sequence of nonglacial beds below the drift at Seattle contains wood fragments ranging in age from about 24,000 to about 15,000 years old (Mullineaux and others, 1965). Radiocarbon dates from material overlying the drift are as old as 13,500 years (Rigg and Gould, 1957). Thus the Puget lobe of Vashon age did not reach Seattle (or Renton) until after 15,000 years ago, and it had retreated by 13,500 years ago. The Vashon Stade, then, represents only a brief glacier advance that occurred late in the Fraser Glaciation.

The youngest glaciation of the Puget Sound lowland has, since early investigations, generally been regarded as equivalent to the Wisconsin Glaciation in central United States, because the Vashon Drift has undergone only slight weathering or other modification. Radiocarbon dates show that the Fraser Glaciation is approximately equivalent to the "classical" Wisconsin of Flint (195\%) and the Woodfordian Substage of the Wisconsinan Stage (Frye and Willman, 1960). The first few radiocarbon dates from above the Vashon Drift in the Puget Sound lowland suggested that the Vashon advance was approximately contemporaneous with the maximum (Tazewell Stade) advance of continental ice into central United States (Waldron and others, 1957; Rigg and Gould, 1957; Crandell and others, 1958). The dates obtained later from below the drift at Seattle, however, show that the Vashon advance did not occur until well after the time of the Tazewell maximum of central United States.

The Salmon Springs Glaciation is older than the classical Wisconsin of Flint, but it may not be older than the earliest parts of the Wisconsin Glaciation of central United States. A sample of peat (W-672) from between two drift members of the Salmon Springs Drift at the type section has been dated as more than 38,000 years old (Crandell, 1963). Another sample from the same peat bed has been dated definitely as at least 50,000 years old, and possibly no older than about that age, by Dr. J. C. Vogel of the Natuurkundig Laboratorium of the Rijks-Universiteit at Groningen (J. C. Vogel, written commun., 1965; and reported in Easterbrook and others, 1967). No strong weathering of the Salmon Springs Drift is known that would record a long interglacial interval comparable to the Sangamon Interglaciation of central United States. Neither is there evidence of a climate as warm as that of Sangamon time in nonglacial sedi- ments that separate members of the Salmon Springs Drift (Crandell and others, 1958) or that separate the Salmon Springs from Vashon Drift (Mullineaux and others, 1965; Armstrong and others, 1965). Consequently, the Salmon Springs Drift is regarded as younger than the Sangamon Interglaciation. If that is correct, the Salmon Springs Glaciation is correlative with some older part of the Wisconsin Glaciation. Such an episode is the Altonian Substage of the Wisconsinan Stage (Frye and Willman, 1960). The Altonian may have included more than one glacier advance, according to Frye and Willman $(1960$, p. 6$)$, just, as did the Salmon Springs.

The Puyallup Interglaciation is interpreted to be a major interglacial episode because of (1) the fairly warm climate recorded by pollen and diatoms in the Puyallup Formation and the probably correlative formation in the mapped area, (2) the amount of weathering in the top of the formation, and (3) the occurrence of a period of erosion between deposition of the formation and the Salmon Springs Glaciation (Crandell and others, 1958). The Puyallup Interglaciation is tentatively correlated with the Sangamon Interglaciation, but it may be as old as the Yarmouth Interglaciation of central United States.

The Orting (?) Drift and the intermediate drift appear to be middle(?) Pleistocene in age and older, but both their ages and their correlations with glaciations elsewhere are uncertain. A nonglacial interval (Alderton Interglaciation) in which the climate was as warm as present, as well as another glacial episoc'e, is recorded between Orting and Puyallup time in the Lake Tapps quadrangle (Crandell, 1963). In the mapped area, both Orting(?) and intermediate drifts record more than one glacier advance. The multiple advances in each glaciation, the Alderton warm episode that probably intervened between the glaciations, and the fact that the Orting(?) is the oldest known drift in the area suggest that the Orting (?) may be as old as the earliest glaciation (Nebraskan) of the central United States.

\section{POSTGLACIAL DEPOSITS}

Deposits termed "postglacial" are postglacial in a local sense and are not necessarily all post-PJeistocene in age. At any particular locality, postglacial sedimentation began as the Puget lobe retreated to a point where it no longer contributed sediment to that locality. But for a considerable time after such sedimentation began in the mapped area, glaciation continued in the northern part of the lowland, during parts of the 
Vashon and Sumas Stades of the Fraser Glaciation (Armstrong and others, 1965; Crandell, 1965). Consequently, a few postglacial deposits of the mapped area may be late Pleistocene in age. More, however, are partly late Pleistocene but mostly Holocene in age, and some are entirely Holocene in age.

\section{LACUSTRINE DEPOSITS}

Lacustrine deposits that consist of peat and lesser amounts of silt, clay, and sand occupy closed depressions and other poorly drained areas on the glacial drift plain and on the floors of the major valleys. Those on the drift plain occur chiefly in ice-scoured basins in ground moraine, in kettles in outwash, and along small stream courses. Two small bogs that lie in shallow swales on the drift plain south of the Green River are dammed by the Osceola Mudflow. On the valley floors, lacustrine sediments generally occur in broad thin layers in flood-plain basins. A few other small peat bogs lie on the valley walls in depressions behind landslide blocks.

The constituent that is typical of the lacustrine deposits is the organic material. According to Rigg (1958, p. 5), the organic material in local peat bogs is chiefly woody, fibrous, sedimentary, and moss peat. Woody peat contains all sizes of plant material from large logs to small fragments. Fibrous peat consists chiefly of the remains of small sedges; $\operatorname{logs}_{\mathrm{s}}$ and other wood fragments do occur but are much less common than in woody peat. Sedimentary peat consists of the remains of small aquatic plants and animals, and moss peat consists mainly of small fragments of leaves and stems of sphagnum mosses. Most shallow bogs and the upper parts of deeper ones consist of fibrous or woody peat; but in a few, moss peat is extensive. Sedimentary peat generally is confined to the lower part of thick lacustrine deposits. Rifle, Mukilteo, and Greenwoud bog or peat soils are composed chiefly of woody, fibrous, and moss peats, respectively (Poulson and others, 1952, p. 102; Rigg, 1958, p. 9).

Lacustrine deposits on the drift plain are largely peat and are relatively low in mineral material except along permanent streams such as Big Soos Creek. In bogs that lie on ground moraine, the peat generally is underlain by thin deposits of lacustrine silt, clay, or sand; in bogs on permeable outwash, organic material more commonly overlies gravel or sand directly. Locally, silt and clay was deposited in ponds formed temporarily by ice. Marl occurs in some peat deposits (Rigg, 1958, p. 10), as does diatomite. A single volcanic ash layer $1 / 2-2$ inches thick, which extends over much of the Puget Sound lowland, occurs persistently in the peat bogs (Hansen, 1947; Rigg, 1958). The ages of peat samples from just below this ash layer in one bog in sec. 32, T. 22 N., R. 6 E., about 2 miles east of Covington, and in another at Arrow Lake about 13 miles farther west, have been determined by radiocarbon analyses to be about 6,500 and 6,600 years, resnectively (Rigg and Gould, 195\%, p. 354; Rubin and A lexander, 1960 , p. 164). Until recently, the ash of this layer was believed to have come from Glacier Peak volcano in northern Washington (Hansen, 1947; Rigg and Gould, 1957). Subsequent work, however, that included comparison of analyses of pumice and ash from Glacier Peak and from Mount Mazama at Crater Lake, Oreg., and more detailed petrographic examination of the ash layer in the Puget Sound lowland has shown that the ash layer of the peat bogs originated at Mount Mazama (Powers and Wilcox, 1964). Ash samples from the Covington and the Arrow Lake bogs are among those identified as part of the Mazama ash layer (R. E. Wilcox, oral commun., 1966).

Three drift-plain peat bogs in the mapped area were studied in detail by Rigg (1958) as a part of ar inventory of peat deposits in Washington. Two ars on outwash in the Black Diamond quadrangle, and another is on ground moraine in the Renton quadrangle. Each bog is isolated from large drift-plain streams, is fairly free from silt and clay, and contains the Mazama ash layer. The thinnest of the three deposits lies on ground moraine at Panther Lake in sec. 4, T. $22 \mathrm{~N}$., R. 5 E.; its maximum known thickness is about 23 feet (Rigg, 1958, p. 84). Peat is about 32 feet thick in a kettle bog in secs. 2 and 3, T. 21 N., R. 6 E., abcrit 2 miles north of Black Diamond (Rigg, 1958, p. 88). The thickest peat found by Rigg $(1958$, p. 77$)$ in the State is in the Covington bog in sec. 32, T. 22 N., R. 6 E., which is also in a kettle; this peat is at least 63 feet thick. Other thick peat deposits on the drift plain probably are similar to those examined by Rigg. The numerous peat layers along Big Soos Creek and other smaller creeks generally are much thinner and contain relatively abundant mineral matter.

Two silt and clay deposits that contain very little peat lie on the ground moraine northeast of Auk'urn, one in sec. 4, T. 21 N., R. 5 E., and another in s?c. 3 of that township and in sec. 34 of T. 22 N., R. 5 E. The former was laid down in a short-lived ice-darmed lake, and the latter in a temporary basin dammed by outwash sand and gravel.

Valley-floor lacustrine sediments occur mostly in $\mathrm{Du}$ wamish Valley; in other major valleys, lacustrine deposits have not been separated from fine-grained overbank alluvium. The lacustrine sediments are chiefly 
thin peat deposits, which lie at the surface along the edge of the flood plain and which also are interbedded in the upper few feet of alluvium. Only one peat deposit within the mapped quadrangles is large; this one is about 2 miles south of Renton on the east side of the valley floor. Typically, peat in that area is much mixed with inorganic material, and it grades laterally to organic-rich silt and clay. This bog was also examined by Rigg $(1958$, p. 74$)$, but he drew no profile, probably because of the large proportion of mineral matter. Although the peat contains much silt and clay, it is still soft enough so that in places it can be penetrated readily as much as 15 feet deep by a peat auger.

Pollen is abundant in lacustrine sediments, as are diatom fragments just above the Mazama ash layer, and mollusks have been recovered from a few bogs. Pollen from a peat bog in secs. 2 and 3, T. 21 N., R. 6 E., about 2 miles north of Black Diamond, has been studied by Hansen (1941). He concluded that the pollen profile there records the change from a cool to the warmer climate of the present, but not other fluctuations that are indicated by evidence elsewhere in the Pacific Northwest (Hansen, 1947). Mollusks recovered from marl at the bottom of the Covington bog have been identified by D. W. Taylor of the U.S. Geological Survey as follows: Pisidium casertanum (Poli), Valvata, Lymnaea palustris (Müller), and Gyraulus parwus (Say). According to Taylor, all these are restricted to fresh-water environments.

Although two lacustrine silt and clay deposits probably are late Pleistocene in age, most of the postglacial lacustrine deposits are of late Pleistocene and Holocene age. A few deposits, notably those on the valley floors and the two adjacent to the Osceola Mudflow, are entirely Holocene in age. The postglacial sedimentation in the area started shortly after retreat of the Puget lobe; postglacial peat samples from Lake Washington and a bog 60 miles farther north have been dated as approximately 13,600 and 12,900 years old, respectively (Rigg and Gould, 1957; Rubin and Alexander, 1958, p. 1476). Rigg and Gould (1957) also attempted to date the start of peat formation in the deep Covington bog, but a sample of basal peat from a depth of 63 feet at the deepest probed site in the bog was dated as only about 10,200 years old. It is possible that the material sampled was not the oldest peat in the bog or that contamination during deep sampling resulted in an anomalously young date. But it is also known that the site of the Covington bog was occupied by a thick block of stagnant ice, and a considerable amount of time must have passed before it melted and allowed peat formation to begin.

\section{TERRACE ALLUVIUM}

Alluvium deposited on flood plains by the White, Green, and Cedar Rivers as they cut down into the drift plain is preserved locally on terraces along the present valley walls. Flood-plain remnants regarded herein as terraces include only those standing distinctly above the present valley floors; even relatively high parts of the present valley floors that onl! occasionally are flooded are regarded as part of the rodern flood plain.

Within the mapped area, extensive postglacial terraces occur only along the Green River in the Black Diamond quadrangle. Elsewhere, they are small or have been so disturbed by landsliding that the daposits are described as part of the colluvium. The most extensive terraces occur high on both walls of the Green River valley at the east edge of the Black Diamond quadrangle. Farther west along the north side of the river, a flight of rock-defended terraces is preserved in sec. $2 \pi$, T. 21 N., R. 6 E., and a single broad terrace is preserved in sec. 25 , T. 21 N., R. 5 E., near the west edge of the quadrangle. In sec. 27 , terraces form a series of steps from nearly the top to the bot'som of the north valley wall, which is underlain by bedrock. In contrast, only one questionable river terrace is preserved on the opposite side of the valley, where the valley wall is underlain chiefly by Pleistocen: sediments. Smaller, mostly unmapped terraces occur elsewhere along the Green River valley and along the valleys of the White and Cedar Rivers, but they are not abundant. Sandy gravel, probably derived from a postglacial terrace, occurs on slump blocks halfway up the south valley wall of the Green River in sec. 30 , T. 21 N., R. 6 E., but no terrace landform is evidert now. Probable terrace sand and gravel also occurs on landshide blocks along the southwest side of the White River valley in sec. 34, T. 21 N., R. 5 E. Very likely, terraces were once much more extensive along each of the major valleys, but they have been removed as the valley walls retreated by landsliding.

Terrace alluvium along the Green River ocsurs in sheets of gravel and sand only about 15-30 feet thick rather than in thick fill deposits. In the easternmost group of terraces, the alluvium consists chiefly of wellsorted sandy pebble-and-cobble gravel. In the fl: oht of rock-defended terraces farther west, the terrace deposits also consist of sand and gravel but exhibit a wide range in grain size. The upper terraces, at altitudes of about $350-400$ feet, are capped chiefly by sandy pebble-and-cobble gravel and only a fer boulders. An extensive intermediate terrace at about 325 feet, however, is veneered mostly by boulder-and-cob- 
ble gravel, and the lower terraces are covered chiefly by sand and pebble-and-cobble gravel. On the single broad terrace at the west edge of the Black Diamond quadrangle, the alluvium is mostly well-sorted sand and pebble gravel.

The terraces were formed by lateral swinging of the various rivers against their valley walls as they cut downward through the drift plain in postglacial time. Along the Green and Cedar Rivers, terrace formation started soon after retreat of the glacier and continued into Holocene time. A remnant of the 5,000-year-old Osceola Mudflow that lies at about the level of the present flood plain in the Green River valley proves that in this valley the river had cut down to at least its present altitude by that time. Consequently, terraces along the Green must be between about 14,000 and 5,000 years old. In contrast, terrace remnants in the White River valley in the Auburn quadrangle are less than 5,000 years old, because the river was emplaced along that course by the Osceola Mudflow (Crandell, 1963, p. A68).

\section{COLLUVIUM}

Deposits mapped as colluvium consist chiefly of landslide debris but also include slope wash and even some alluvium on valley walls. The landslides are of widely varying types, but can be separated into two groups (see Sharpe, 1938, or Varnes, 1958, for landslide classifications) : slides, which move mostly as discrete blocks; and flows, which move with much internal deformation and take a form resembling that of a viscous fluid (Varnes, 1958, p. 32). All gradations between slides and flows occur, however, and individual landslides may exhibit both types of movement. Most large slides are slump blocks that are tilted backward as a result of rotation; downslope they often progressively break into smaller blocks and grade to earthflows. Smaller discrete slides are mostly slump blocks or debris slides. A particularly common type of small debris slide consists of one or of perhaps a few trees and the material in which they are rooted. Landslides classed as flows are very abundant, especially mudflows, debris avalanches and debris flows, earthflows, and creep. Flows commonly are interbedded with slope wash and alluvium and probably grade into those deposits. Material described as slope wash is intermediate between landslide debris and alluvium; it is defined as the material moved downslope predominantly by gravity assisted by running water that is not concentrated in channels (Stokes and Varnes, 1955). Alluvium treated as part of the colluvial deposits herein is that alluvium which is moved intermittently by small streams on valley walls, where it is intimately associated with landslide debris and slope wash.

Nearly all steep slopes in the three mapped quadrangles are covered by a mantle of colluvium; this colluvium is thickest and most active on valley walls of streams that have cut dreply into the drift plain in postglacial time. Large block slides are especially extensive in the Black Diamond quadrangle along the Green River and Newaukum Creek, where locally most of the valley wall is laden with slumps as much as several hundred feet long. These slumps are surrounded by smaller blocks, flows, and slope wash. Large slumps are also common in the Auburn quadrongle along the southwest side of the White River and along Soos Creek in sec. 11, T. 21 N., R. 5 E. In the Cedar River valley, large slumps are less abundant, but one large feature in sec. 21 about 1 mile east of Renton (Mullineaux, 1965a) is interpreted to be an ansient slump block. Smaller block slides and other colluvium are widespread elsewhere along the White, Green, and Cedar Rivers and along Soos Creek, even where not shown on the geologic maps, for these deposits were mapped only where thick and continuous enough to prevent identification of the underlying strata.

Slopes modified by the Vashon ice, in contrast, carry considerably less colluvium. Along Duwamish Villey, for example, colluvium other than a thin creep mantle is not extensive except where the Green River has recently cut against the valley wall, as it has about 1 mile north of Auburn. Similarly, colluvium on the drift plain is thick and abundant only where late glacial or postglacial streams have cut sharply into the drift, and generally only creep has affected constructional slopes on ground moraine and outwash gravel.

Colluvium typically is represented by hummocky slide-block topography and the smoother profiles of flows and slope wash. Most landslide areas include slump blocks whose elongate upper surfaces are approximately parallel to and tilted back toward the valley wall. Ponds and swamps commonly form ir. the depressions behind the blocks. Locally, mudflows, slope wash, and alluvium between the blocks smooth mcst of the valley wall. The flow materials may make rather steep coalescing aprons along the base of a valley wall or extend as separate fans out onto the floor of the valley. In a few places, slide blocks also have ridden out onto the valley floor. Landslide topography that develops in the flat-lying Pleistocene deposits is well illustrated along the Green River valley in the Black Diamond quadrangle. Along the valley, the drift plain in several places is bounded abruptly by a steep arcuate scarp that leads down to a broad flatter slope 
formed by a jumble of block slides seemingly afloat in mudflow and alluvial deposits.

Thickness of the colluvium is highly irregular, especially where it is composed partly of large slide blocks. The shapes of some large slumps in the Green River valley indicate that they are at least 50 feet and perhaps more than 100 feet thick, but blocks ranging in thickness from a few feet to probably 20 feet appear to be more common. Other colluvium also is locally thick; near the west edge of sec. 22 , at the base of the south valley wall of the Cedar River, a colluvial sequence composed mostly of mudflows is at least 30 feet thick. However, the landslide flow deposits and associated slope wash and alluvium probably are generally thinner than the slide blocks that they encompass.

Both the composition and the texture of colluvial deposits are widely variable, reflecting the variation of source sediments and amount of disturbance. Colluvium exhibits as much diversity as the geologic formations that crop out in the valley walls, for part is derived from each older formation. Because most is derived from nonindurated Pleistocene deposits that consist largely of clay, silt, and sand, colluvium typically is fine grained. Locally, however, debris flows heading in thick gravels have spread deposits of the gravel far down valley walls and even onto flood plains. Disturbance of component strata is minor in large slide blocks, which may retain structural features of the source beds with little change, but materials in flow deposits generally are much reworked. In the latter, beds of clay, sand, and gravel commonly are broken and juxtaposed or intimately mixed. Changes in grain size and sorting are abrupt, a silty or clayey matrix is almost universal, and bedding is usually crude or absent.

Weak Pleistocene formations, vertical and lateral river erosion, man's activities, and rainfall are the most important of the many factors that cause landslides in the mapped area. (See Sharpe, 1938; and Varnes, 1958, and references therein for discussions of landslide causes.) Some of the factors are nearly constant conditions that operate mostly to determine the location of slides; others change rapidly and tend to determine the timing. Lithologic factors such as weak formations, for example, are almost constant, and so their effect is to determine sites of abundant landslides. In the Green River valley, slides are sparse in the bedrock gorge but are abundant just downvalley where the river has cut into weathered clay-rich Hammer Bluff Formation and Orting(?) Drift. Erosion that produces steep slopes occasionally is rapid enough to trigger slides, but generally it also only determines localities that are especially subject to landsliding. Man's activities, particularly those that undercut or ov rrload slopes, often produce slopes that are subject to sliding. But excavation and filling also commonly disturk slope conditions enough to set slides in motion. The triggering cause of most landslides here, however, probably is rainfall. The water adversely affects slope stability in many ways, and enough so that most landslides occur during the rainy season.

Most of the colluvium mapped is Holocene in age. Older colluvial materials very likely have beer completely reworked or removed, particularly in valleys that were widened and deepened in Holocene time. Locally, landslides are known to be younger than the 5,000-year-old Osceola Mudflow, because they occur in the White River and Newaukum Creek valleys that themselves postdate the mudflow.

\section{OSCEOLA MUDFLOW}

The Osceola Mudflow is a mass of bouldery sandy clay that flowed down the White River valley from Mount Rainier and spread out as a digitate loce over at least 65 square miles of the Puget Sound lowland (fig. 20; Crandell and Waldron, 1954, 1956; Crandell, 1963). It was first described by Willis (1898c) as the Osceola Till, but it has since been redefined as the Osceola Mudflow (Crandell and Waldron, 1气56, p. $361)$.

Only a small thin part of the Osceola extends into the Black Diamond and Auburn quadrangles. South of the Green River in these two quadrangles, it covers parts of the drift plain over an area about 6 miles long and 2 miles wide (fig. 20 ; Mullineaux, 1965b, c). In addition, one small remnant forms a terrace 5-10 feet above the Green River flood plain in sec. 25 about 5 miles east of Auburn. Another remnant has been identified by Luzier (1969) at a depth of 265 feet in $\varepsilon$ water well in Duwamish Valley, 4 miles northwest of Auburn (fig. 20 ). The mudflow generally lies at the surface; thus, its character is well exposed at the tops of valley walls and in drainage ditches. Near Enumclaw (fig. 20 ), it is as thick as 75 feet (Crandell, 1963, p. A47), but in the mapped area the maximum observed thickness is about 15 feet, and the average probably is less than 10 feet.

The mudflow has a nearly flat surface, but locally it laps up onto hillocks of the rolling drift plain. The mudflow surface is poorly drained naturally, and drainage ditches have been dug in most cultivated areas. The average slope of the surface in the direction of flow is only about 25 feet per mile in the westernmost 4 miles of outcrop between the Green and White Rivers. On the flanks of Vashon Drift hills, th 


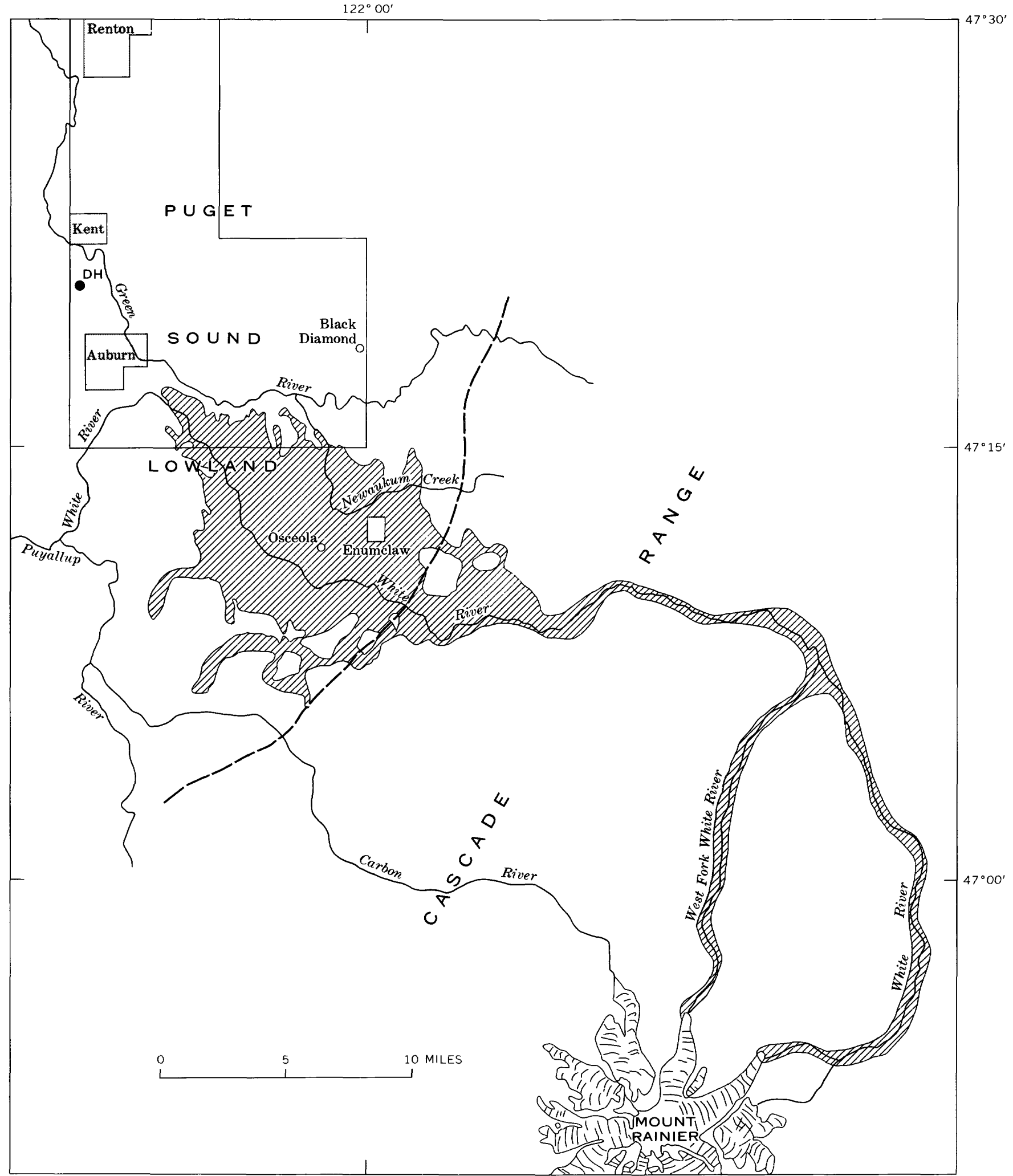

Figure 20.-Distribution of the Osceola Mudflow (patterned area), location of Renton, Auburn, and Black Diamond quadrangles (outlined), and site of water well $(\mathrm{DH})$ in the Duwamish Valley northwest of Auburn in which mudflow was penetrated. Area shown as mudflow includes small areas of Vashon Drift and postmudflow alluvium. Within Cascade Range, pattern shows path of mudflow but does not show actual distribution. From Crandell and Waldron (1956), Crandell (1963), and Luzier (1969). 
mantle of mudflow generally rises only a few feet above the overall surface of the Osceola, but a thin layer may cover drift mounds that are only a few feet higher than the general mudflow surface. Thus, the top of the mudflow apparently was once higher than it is now. Its lowering probably resulted chiefly from compaction after emplacement, but it may have resulted partly from outflow of still mobile mud from under a stationary crust.

The Osceola is an unsorted and unstratified deposit that contains clay, silt, sand, and stones of all sizes up to large boulders. A sample collected by D. R. Crandell from the south valley wall of the Green River near Auburn, from which cobbles and boulders were excluded, consisted of 20 percent silt and clay, 36 percent sand, and 44 percent gravel. Cobbles are common; boulders are scattered only sparsely in and on top of the formation near the Green River but become more abundant southeastward toward the source. Most outcrops that expose both bottom and top of the mudflow show a distinct decrease in size of stones from bottom to top, a feature that is characteristic of this as well as other mudflows (Crandell and Waldron, 1956, p. 352; Crandell, 1957).

The mudflow is composed chiefly of volcanic material from Mount Rainier and from Tertiary andesitic rocks in the Cascade Range. Pebble counts at several Puget Sound localities, involving about 900 stones, indicate that from $1 / 3$ to $1 / 2$ the pebbles are derived from Mount Rainier and that most of the others are derived from Tertiary volcanic rocks (Crandell, 1963). The sand fraction consists largely of volcanic rock fragments, volcanic glass, feldspar, and heavy minerals, of which hypersthene constitutes as much as 95 percent. Montmorillonite is the predominant clay mineral in all samples examined; however, kaolinite, mica (illite), and mixed-layer clay minerals also occur, and in a few samples are nearly as abundant as montmorillonite. Wood is common and generally appears fresh.

The distribution of the Osceola in the lowland shows that it was emplaced as a fluid mass, flowing generally around rather than over obstacles; and its character indicates that it is a volcanic mudflow (Crandell and Waldron, 1956, p. 351). The mudflow has been traced up the White River valley to Mount Rainier, where its distribution indicates that it originated high on the northeast side of the volcano. Crandell and Waldron $(1956$, p. 360$)$ originally suggested that the mudflow was initiated by partial collapse or explosive destruction of part of the volcano as a result of eruption. After studies of surficial deposits at Mount Rainier, Crandell (1963) proposed that the Osceola resulted from one of several major avalanches that distroyed the former summit of the mountain. Phreatic explosions were regarded as the most likely cause, brt initiation by earthquakes or slope failure after oversteepening by glacier erosion was considered possible. In contrast to these hypotheses, Fiske, Hopson, and Waters (1963) proposed that the mudflow was formed by the collapse and the flowing out of a thick fill of watersaturated sediments in the upper part of the White River valley. Distribution of remnants of the Osceola on the flanks of the volcano well above the White River valley, however, seems to show clearly that the mudflow originated somewhere on the volcano frr above the White River valley.

Discovery of a brown podzolic soil profile in Vashon Drift beneath the mudflow (Crandell and $\mathrm{V}^{\top}$ aldron, 1956 , p. 35i) first showed that the Osceola was significantly younger than the Vashon Drift. Shortly thereafter, three wood samples from the mudflow in the lowland and along the edge of the Cascad. Range were dated by radiocarbon methods as about $4 ., 700,4,-$ 800 and 4,950 years old (Crandell, 1963, p. A49). Another wood sample, from the mudflow buried in alluvium in the Duwamish Valley northwest of Auburn, was determined to be about 5,000 years old (Luzier, 1969). Consequently, the Osceola is regarded to be, in round figures, 5,000 years old.

\section{FLOOD-PLAIN ALLUVIUM}

Modern flood-plain alluvium includes some small deposits from creeks that head on the drift plain, but it consists mainly of alluvium from the Cedar, Green, and White Rivers. The topographically higher parts of alluvium on the major valley floors could be classified as terrace deposits according to an interpretation of Wolman and Leopold (1957, p. 105), inasmucl as they stand above the level of annual or biennial flooding. However, definition according to flood frequensy is not used herein. First, the deposits appear to be a lithologic unit that is continuous from the high, laast frequently flooded parts of the valley floors to th $\cdot$ lower, more regularly inundated parts. Second, in a large part of Duwamish Valley, levees along the modern channel are among the least frequently floodad parts of the valley floor. Perhaps more important, food frequency in these valleys has been altered by man's activities. The present flood frequency is nct, representative of that of the recent past, and additional river control might further protect the valley bottoms from flooding. Consequently, all the main-strenm alluvium on the valley floors is considered to be modern flood-plain alluvium. 
Deposits of small streams that head on the drift plain are all small, and they vary widely in content, width, and thickness. Creeks that cross the surface of the drift plain necessarily have low gradients, and they have had to alternately cut and fill to attain their present profiles. Consequently, the deposits are highly diverse even along a single stream. Where such a creek has cut into the drift, its alluvium typically consists of only a thin and narrow band of sand and silt. Where it has filled instead, the deposit is broader and thicker, and the sand and silt are interlayered and flanked with clay and peat. Along the margins of the drift plain, a few of the larger drift-plain streams such as Newaukum and Soos Creeks have cut deep trenches that lead sceeply down to the major valley floors. Along the deep reaches, alluvium of these creeks consists of thin and narrow strips of gravel and sand with little associated silt, clay, or peat. Alluvium of Newaukum Creek, for example, forms a continuous band of pebbleand-cobble gravel and sand only a few tens of feet wide except in its broader terminal fan on the Green River valley floor. Alluvium of Big Soos Creek is similar (though somewhat finer grained) except in the lower mile or two of its valley, where the deposit widens to about 500 feet and probably thickens to at least 50 feet. In that area, the deposits at the surface consist of gravel and sand 50-100 feet wide along the creek, and of sand and silt elsewhere on the surface of the flood plain.

Smallest of the alluvial deposits are those of streams flowing directly down the valley walls. They typically are not only narrow and thin but commonly grade into or are interbedded with colluvium. Generally such alluvium has not been mapped except where it broadens into a fan at the base of a valley wall. The deposits consist largely of sand and silt but locally are pebble or cobble gravel.

In contrast, deposits of the three major rivers in their own valleys and in Duwamish Valley are thick and widespread, covering about a fifth of the total area of the Renton, Auburn, and Black Diamond quadrangles.

\section{GEDAR RIVER VALLEY}

The major part of the Cedar River valley floor in the 4-mile-long segment in the Renton quadrangle is covered by alluvium, although colluvium and sidestream alluvium are proportionately more abundant there than on the floor of any other major valley. In the upvalley segment of about 3 miles, valley-bottom sediments are about a third of a mile wide; westward they narrow to about 400 feet in a bedrock gorge 1 mile east of the center of Renton (Mullineaux, 1965a).
The depth of main-stream alluvium is not well known along any part of the valley. A thick fill in Duwamish Valley at Renton suggests that alluvium is at least 100 feet thick at the valley mouth, but the bedrock 1 mile upstream might have limited the downcutting so trat the deposits farther up the valley are no more than 20-30 feet thick.

Although the Cedar River heads high in the Cascade Range, most of its alluvium in the lower valley is derived from the lower part of the drainage basin, for Cedar Lake in the Cascades traps most material derived from the upper part. Constituent rock fragments and minerals are obtained principally from volcanic rocks of the Puget Group and younger Tertiary andesitic rocks, and to only a minor extent from the Snoqualmie Granodiorite and similar plutonic bodies and glacial drift. Gravel of the Cedar River at Renton, therefore, is composed chiefly of greenish-gray and gray volcanic rocks. Light-gray granitic rocks and metamorphic rocks from the drift are common, though they make up only a small proportion of the grarel. Heavy-mineral suites from sand consist largely of hypersthene, amphibole, clinopyroxene, altered lightgray and yellow minerals, small rock fragments, and opaque minerals (table 2 ).

Sediments on the floor of the Cedar River valley consist largely of narrow strips of pebble-and-cobble gravel and coarse sand in and near the river channel, and broader flanking deposits of finer sand and silt. In several places, however, the coarse channel materials widen to cover as much as half the breadth of the flood piain. Grain-size studies of channel deposits by L. A. Palmer (written commun., 195\%) indicate that more than half a typical channel bar in the Renton quadrangle consists of pebble-size stones and that a third to a quarter of the bar consists of cobbles. The flanking silt and sand appears to be only a few feet thick over gravel in much of the valley, but locally, gravel-free deposits as much as 10 feet thick have been exposed in trenches.

\section{GREEN RIVER VALLEY}

Alluvium of the Green River that thickens progrossively westward covers the floor of the Green Rirer valley except for the parts covered by minor amounts of colluvium and side-stream deposits and for a small area at the valley mouth that is covered by Write River deposits. In the bedrock gorge near the east margin of the Black Diamond quadrangle, flood-plain alluvium of the Green River is thin and as little as a few hundred feet wide. About 1 mile west, howerer, the alluvial floor widens to about a mile and, concurrently, the deposits thicken. A maximum thickness at 
the valley mouth of more than 75 feet is probable, because the Green River must have aggraded at least that much in response to White River aggradation in Duwamish Valley. Records and logs of wells in secs. 16 and 21 , a mile up from the valley mouth, according to Luzier (1969), indicate that the Green River deposits there may be at least 120 feet thick.

Alluvium of the Green River is composed chiefly of greenish-gray and dark-gray volcanic rock and mineral fragments that were derived from Tertiary andesitic rocks in the Cascade Range. Although the Green River flows through a gorge cut into Puget Group arkose just east of the Black Diamond quadrangle, no more than a few percent of pebbles in the alluvium are derived from the Puget Group. Somewhat more material appears to have been derived from Pleistocene sediments, because pebbles of northern provenance are more common than those from the Puget. Heavy minerals from the Green River sediments are mostly hypersthene, amphibole, clinopyroxene, altered green and yellow minerals, rock fragments, and opaque minerals (table 2). Hypersthene and clinopyroxene are more abundant than in alluvium along the Cedar River, and light-gray altered minerals are much less common.

Channel gravel and sand, flanked by overbank sand and silt that grades laterally into flood-basin silt, clay, and peat, compose the valley-floor alluvium at the surface. Although coarse channel material appears only as narrow strips along much of the valley, it broadens greatly at two localities where the river has recently been migrating rapidly by cutting against the outside banks of meanders. For about 3 miles below the mouth of Newaukum Creek, the band of coarse channel deposits, though fluctuating greatly in width, probably averages about 1,000 feet in width and covers nearly a third of the flood-plain surface. Similarly, in the mile downvalley from the mouth of Big Soos Creek, gravel and coarse sand form the flood-plain surface in a band that averages about 500 feet in width.

Channel gravel of the Green River in the Auburn and Black Diamond quadrangles consists chiefly of pebbles, with lesser amounts of cobbles and sand. To determine the grain size of bedload being carried, samples were taken at low water from bars at several points along the river between the bedrock gorge on the east and the valley mouth near Auburn. After the lag pavement or armor (Straub, 1942) of stones was cleared from the bar surface, $40-50$ pounds of material, excluding boulders, was dug and sieved at each sample site. In the sample from the easternmost site, near the mouth of the bedrock gorge, the mean diameter of all particles was about $4 \mathrm{~cm}$, and about 30 percent of the sample was of cobble size $(>6.4 \mathrm{~cm})$. Boul- ders as large as $40 \mathrm{~cm}$ across are scattered over the bar, and several much larger ones, probably derived from the adjacent valley wall, lie on the surface of the bar. In the sample taken nearest the valley mouth, the mean diameter was slightly more than $2 \mathrm{~cm}$, and only about 10 percent of the stones were of coblle size. Boulders as large as $20 \mathrm{~cm}$ across are present on the bar at this point, but noticeably larger boulders are absent, probably because any such boulders derived from valley walls here were buried during aggradation of this part of the flood plain.

Orerbank sediments in the Green River volley include sand deposits similar to those called flood-plain splays by Happ, Rittenhouse, and Dobson (1940), and channel-fill and flood-basin deposits of sand, silt, clay, and peat. In the part of the valley in the Bleck Diamond quadrangle, overbank material appears to be chiefly sand in flood-plain splay and channel-fill deposits that apparently rapidly cover coarse channel sediments. Coarse channel deposits along several meander segments cut off and abandoned since 1937 were largely covered by silty sand by 1959 ; several inches of overbank sand and silt were laid down in the same part of the valley during floods early in 195e. Exposures along the present channel show that, at least locally, these overbank deposits are no more than a few feet thick.

Flood-basin sediments are more abundant in the Auburn than in the Black Diamond quadrangle, although sand of uncertain origin is a major constituent of the alluvium there. Sand without grevel, for example, was predominant in the walls of a pipeline trench excavated across the valley floor in sec. $22, T$. 21 N., R. 5 E., along nearly half its length. Sard interbedded with channel gravel was exposed along nearly a quarter of the trench, which also intersected one abandoned and filled channel that contained several buried logs. Flood-basin silt, clay, and interbedded peat as much as 10 feet thick formed the walls of the trench along approximately a third of its length. Nearer the valley mouth, fine-grained deposits may be even more abundant; in secs. 20 and $21,10-20$ feet of peaty silt and clay was penetrated in several auger holes. In addition, the $\log$ of a 70 -foot well in-sec. 21 shows only "peaty sand" (Luzier, 1969).

\section{WHITE RIVER VALLEY}

The valley floor is occupied by thin coarse alluvium and a little side-stream alluvium or colluvium. In the 4-mile segment in the Auburn quadrangle, the valley floor is about half a mile wide, and the thic'ness of sediments probably is about equal only to the depth of scour of the river, perhaps $20-30$ feet. This alluvium is 
inferred to be thin because the White River valley has been cut concurrently with, rather than before, the filling of Duwamish Valley. Hence, little or no aggradation in the White River valley would be expected in response to filling of the Duwamish Valley.

Alluvium of the White River is distinctive because of its high proportion of material derived from Mount Rainier. This proportion is far greater than would be expected from the small area of the drainage basin occupied by the volcano. Several factors probably contributed to this abundance of Mount Rainier detritus. Fragmental or weakly agglutinated pyroclastic rocks and breccias, for example, are abundant on the volcano (Russell, 1898; Coombs, 1936; Fiske and others, 1963). Glaciers on the mountain contribute a large amount of detritus to the rivers. Mechanical weathering is probably more effective at the heights reached by the volcano than at the lower altitudes of the nearby Cascades, and the White River and its tributaries rework abundant mudflow and debris flow deposits that line their valleys between the volcano and the Puget Sound lowland (Crandell, 1963, p. A54). Pebbles and cobbles in the alluvium are mostly opentextured to dense dark-gray to brick-red andesite from Mount Rainier and greenish- to dark-gray volcanic rocks from older volcanic rocks in the Cascades. Heavy minerals are predominantly hypersthene, which composes as much as 90 percent of the heavy fraction of some samples. The remainder of heavy-mineral suites consists largely of clinopyroxene, amphibole, rock fragments, and opaque minerals (table 2). Many mineral grains are coated with red hematite(?); hence, sandbeds as well as gravel deposits have a reddish cast that distinguishes them from Cedar or Green River sediments.

Channel deposits of pebble-and-cobble gravel and sand cover nearly all the floor of the valley, and only discontinuous strips of medium and fine sand along the edges of the valley appear to be overbank material. Two samples of modern bar gravel along the White River were taken and sieved, in the same manner as those from Green River bars. One was taken approximately where the river enters the Auburn quadrangle, and the other where it leaves the quadrangle. In the upstream sample, the mean diameter was approximately $7 \mathrm{~cm}$, and about half the stones were of cobble size. Boulders as much as $50 \mathrm{~cm}$ across were common at the site, and much larger ones derived from the Osceola Mudflow and from drift in the valley walls were evident on the flood plain nearby. In the downstream sample, the mean diameter was nearly $5 \mathrm{~cm}$, and about 30 percent of the stones were of cobble size. Boulders as large as about $25 \mathrm{~cm}$ were fairly common, but significantly larger ones were absent. Large boulders would seldom be carried to the downstream site, which is near the center of Duwamish Valley, and those that were would soon be buried by aggradation there.

\section{DUWAMISH VALLEY}

Alluvium in the mapped part of Duwamish Valley forms a thick deposit that partly fills the deep, wide glacial trough that lies along the west side of the mapped area. Unconsolidated deposits underlying the valley floor are known from well borings to be at least several hundred feet thick (Luzier, 1969). In places, Vashon Drift mantles the valley wall and passes down under the flood-plain sediments; lacustrine or fluvial stratified drift, as well as till, undoubtedly locally underlies the postglacial material at depth. The upper part of the postglacial sediments, of which about 100 feet was penetrated by auger during this study, consists almost entirely of alluvium from the three major rivers of the area. Both White River and Cedar Piver alluvial sediments form extensive, distinct lithologic units in Duwamish Valley, although these units are interfingered and gradational along their margins. In contrast, alluvium of the Green River probably oscurs only as a buried delta or fan that underlies White River sediments at Auburn (fig. 21), as narrow kands of channel sediments along the modern river course, and as a minor constituent of the alluvium of the combined White and Green Rivers.

Alluvium of the Cedar River forms a distinct fan in Duwamish Valley at Renton. It slopes at about 15-20 feet per mile from the mouth of Cedar River valley at the east edge of the city northward to and beroath Lake Washington, westward to the opposite $v^{\text {r.lley }}$ wall, and southwestward toward Tukwila. About 11/2 miles southwest of the valley mouth, the fan passes under deposits of the White River. About 1 mile farther southwest at Longacres, Cedar River sediments underlie White River deposits at about 50 feet below the surface and extend to a depth of at least 90 feet. Logs of holes drilled in 1956 at the site of a Boeing Co. plant in the northern part of Renton, in the NW1/4 sec. 8 , T. 23 N., R. 5 E., show that the alluvium of the Cedar River there extends from the surface to a depth of at least 130 feet, about 100 feet below present sea level. The Cedar River fan consists largely of sand and gravel but includes interbedded layers of silt, clay, and peat and at least one layer of volcanic ash. With increasing distance from the mouth of the Cedar Piver valley, the gravel and sand not only become finer grained but are interbedded and overlapped by increasingly thicker deposits of sand and silt. Although 

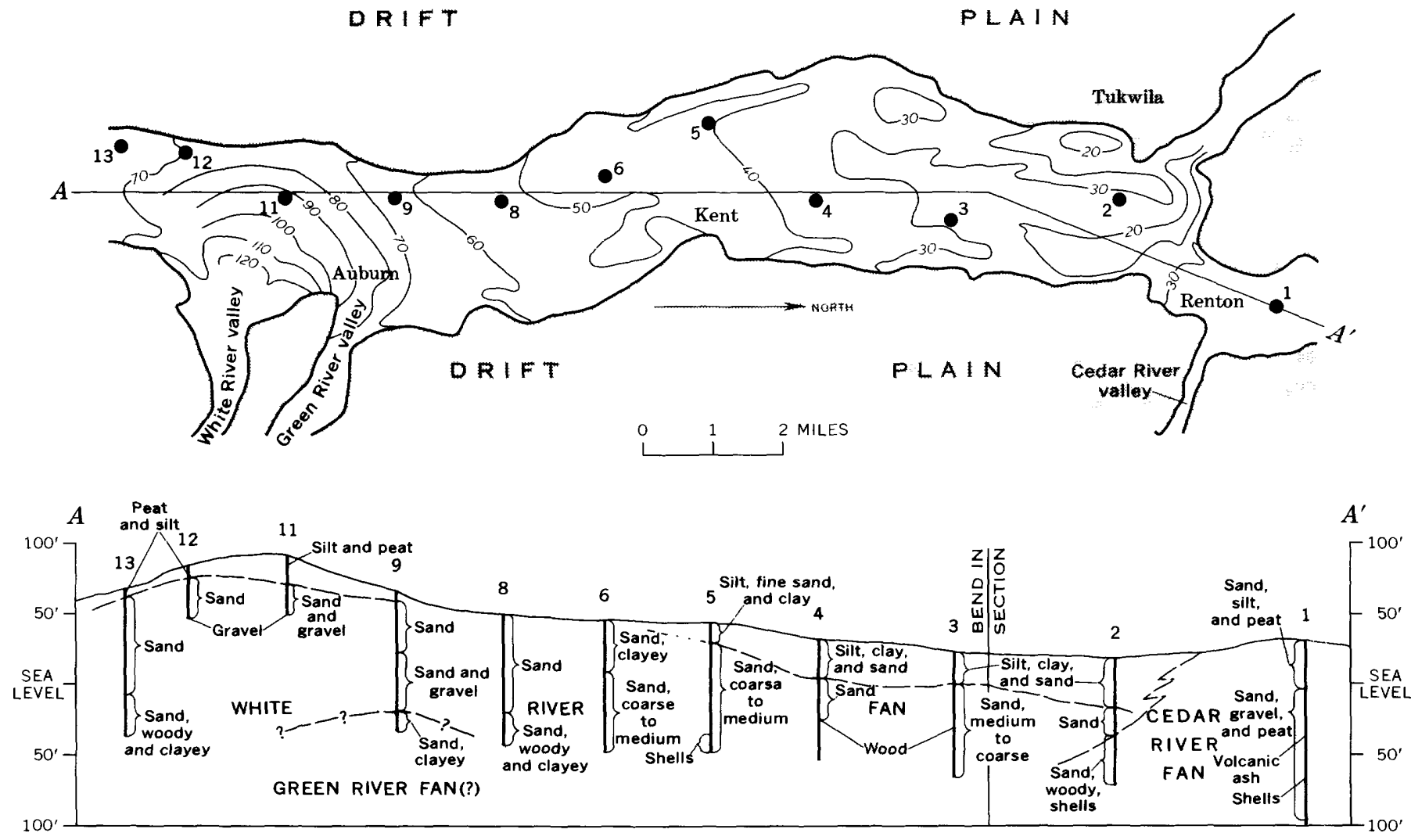

FIGURE 21.-Topographic map and section of upper part of postglacial fill in Duwamish Valley. Contours are in feet, sketched from U.S. Army Corps of Engineers map of Green and Duwamish Rivers, No. E-12-7-37; datum is mean lower low water. Hole 1 (black dot) is boring at Boeing Co. site; all others are U.S. Geological Survey auger holes.

largely covered by artificial fill now, peat formerly was fairly extensive at the surface along Duwamish Valley walls near Renton.

Most of the alluvium in Duwamish Valley, however, is included in a unit that is a fan of the White River. The White River fan forms the floor of the entire Duwamish Valley (except for that part formed by the Cedar River fan) from the Puyallup Valley northward to the Duwamish River mouth at Seattle (Willis, 1898c). Lithologically, the fan consists dominantly of White River material, but north of the city of Auburn it contains a small proportion of detritus carried in by the Green River, which prior to 1906 joined the White at Auburn. Near its apex at the mouth of the White River valley, the fan is a smooth topographic feature that slopes outward at about 40 feet per mile. This distinct, relatively steep part of the fan is readily recognizable from the south boundary of the Auburn quadrangle northward to about the north edge of Auburn. Detailed contours of the valley floor (fig. 21) show that the White River fan even extends a few hundred yards up the Green River valley at Auburn. North of Au- burn, the fan shape is much less distinct. The valley floor north of the city shows increasingly moro local relief and becomes characterized by multiple meandering channels, broad curved natural levees, and low flood-basin areas.

The main component of the White River fan is channel sand and gravel composed almost entirely of detritus from the White River. Where the river issues from its own valley, the channel deposits lie at the surface, though farther down the fan they become buried by a thickening wedge of overbank silt, sand, clay, ard peat. At the fan apex, the alluvium is chiefly coblle-andpebble gravel overlain by at most a few feet of sand. The gravel becomes progressively smaller in size, and the overlying sand thickens with increasing distance from the apex. In three auger holes (nos. 9, 11, and 12, fig. 21), all between 2 and 3 miles from the apex, gravel was struck below 20-40 feet of sand; and in two 95foot holes (nos. 13 and 8, fig. 21) in alluvium of the White River about 3 and 4 miles south west and northwest, respectively, from the apex, no gravel was encountered. North of Auburn, several other augær holes 
show that coarse to fine sand forms most of the alluvium under the thin wedge of finer overbank materials at the surface. From Auburn north to Tukwila, the sand unit was found to extend to at least 95 feet below the present surface (fig. 21). Clay and silt in minor amounts were recovered with the sand, but they apparently do not form thick layers. No peat layers were identified, though pieces of wood appeared to be distributed sparsely throughout the sand unit.

Deposits at the surface from Auburn north consist chiefly of overbank silt, sand, and clay laid down partly by the Green River but mostly by the combined Green and White Rivers during times when the White flowed northward in Duwamish Valley. In the upper few tens of feet, channel gravel and sand apparently occurs only along present and abandoned channels of the main rivers; in abandoned channels, it probably is overlain by silt, clay, and peat. The overbank deposits generally range in thickness from a few feet to about 40 feet. At a borrow-pit site in sec. 23 , west of Kent, fine sand and clayey silt from 15 to 20 feet thick overlie coarse to medium sand, and in sec. 24 about 2 miles southwest of Renton, auger holes indicate that silt, clay, fine sand, and interbedded peat averaging about 30 feet in thickness overlie coarse to medium sand. At the surface, material in natural levees consists mostly of fine sand and coarse silt, whereas finer silt, clay, and peat form the surface in flood basins between the levees and adjacent to the valley walls. Peat is especially abundant along the east and west sides of Duwamish Valley just south of Renton and Tukwila.

Fossils are widespread in Duwamish Valley fill and also in the Puyallup River valley fill to the south (Crandell, 1963). In Duwamish Valley, fossils have been recovered from an auger hole west of Kent at about 40 feet below mean sea level, from another auger hole near the Longacres race track southwest of Renton at about 40 feet to more than 50 feet below sea level, and from drill holes at a Boeing Co. plant site in northern Renton at about 75 feet below sea level (fig. 21). Fossils from the Kent, Longacres, and Boeing plant holes, identified by E. J. Moore of the U.S. Geological Survey, were limpets (Acmaea), periwinkles (Littorina), mussels (mytilid), Cryptomya, Mya, barnacles, and a few echinoid spines, all of which are marine. According to Mrs. Moore, no fossils in these collections suggest a depth of water greater than a. few fathoms; and the limpets, periwinkles, mytilid mussels, and barnacles presumably lived where they were exposed at low tide. Hence, the fossils show that Duwamish Valley was an arm of Puget Sound during some parts of postglacial time. Furthermore, the pres- ence of these tidal-range fossils at depths of as much as 75 feet below present sea level suggests that relative sea level during part of postglacial time was several tens of feet lower than at present.

Postglacial sediments have accumulated continuously in Duwamish Valley since retreat of the Vashon glacier. They began to form as the Cedar and Green Rivers built deltas or fans into the valley. The Cetar River continued to build its fan rapidly until the fan extended across the main valley and blocked off Lake Washington from Puget Sound. Studies of Lake Wrshington (Rigg and Gould, 1957; Gould and Budinger, 1958) suggest that the lake was established by akout 13,500 years ago. Marine shells that may have keen deposited while the lake was an arm of the sound are overlain by peat, two samples of which were dated as about 13,600 and 14,000 years old, respectively (Rigg and Gould, 1957; Broecker and Kulp, 1957, samples L-330, L-346A). The layer of volcanic ash founc in drill holes at the Boeing plant site in Renton may be part of the widespread Mazama ash that is about 6.600 years old (Powers and Wilcox, 1964). If so, the 60 feet of alluvium of the Cedar River overlying the ash has been laid down at a rate of about 1 foot each huno'red years.

However, most of the sediment in the valley in the White River fan was deposited in less than 5,000 yenrs, or since the Osceola Mudflow diverted the lower segment of the river to Duwamish Valley at Auburn (Crandell, 1963). Deposition of White River material, as much as 300 feet thick (Luzier, 1969), thus occurred much more rapidly than deposition of the Cedar River sediments. Furthermore, deposition of the lower gravel and sand unit of the White River fan might have required only a small part of post-Osceola time.

\section{GEOMORPHOLOGY}

The dominant landscape features of the mapped area are the drift plain; the wide north-trending Duwamish Valley; and the narrower west- to northwesttrending Cedar, Green, and White River valleys. All these features originated during Quaternary time. The drift plain is part of a widespread, complex fill in the lowland that is composed largely of glacial sediments. The Duwamish Valley was excavated during or before the Vashon Stade - the time and manner of origin of that and similar valleys (and the intervening driftplain segments) probably has been the most discursed geomorphic problem of the area. Most of the present drainage pattern was developed as the Vashon glacier retreated, though the White River was positioned later by the Osceola Mudflow. Entrenchment of the major 
river valleys and aggradation of the Duwamish Valley floor have been effected chiefly or wholly by the Cedar, Green, and White Rivers in postglacial time.

\section{ORIGIN OF DUWAMISH VALLEY AND ADJACENT DRIFT PLAIN}

Duwamish Valley and the adjacent segments of drift plain exhibit a relation typical of the Puget Sound lowland in that low-relief "plateaus" stand several hundred feet above wide northerly trending deep "troughs." Some of these troughs are arms of Puget Sound; others, like Duwamish Valley, formerly were arms of the sound but now are aggraded to above sea level.

The origin of the "troughs" and "plateaus" has been repeatedly discussed in the literature (LeConte, 1874; Kimball, 1897; Willis, 1898c; Bretz, 1913; Crandell and others, 1965). In most early reports, origin was attributed to either subaerial erosion of a preexisting plain by rivers or glaciers (LeConte, 1874) or preservation of preglacial valleys as the intervening divides were built up into plateaus (Willis, 1898c). Willis (1898c) first discussed the two ideas in detail, largely on the basis of his work in the Puyallup-Duwamish Valley. He referred to the first idea as the erosion hypothesis and to the second as the construction hypothesis. Willis noted that Vashon Drift not only mantled much of the Duwamish Valley wall, but also raised the adjacent drift-plain margins by deposition. Because he reasoned that the available evidence favored the construction hypothesis, he proposed that the Duwamish and similar valleys probably had been preserved through Pleistocene time by ice tongues that occupied preglacial valleys and had been maintained by them as ice-marginal outwash built up the adjacent divides into plateaus.

Later investigations, however, led to general acceptance of a version of the erosion hypothesis. Bretz (1913) noted that the plateaus were not constructed over bedrock divides and that continuity of some formations from plateau to plateau showed that they were parts of a continuous fill. According to Bretz, the fill formed during a single glaciation, the Admiralty. The troughs originated when rivers cut down into the fill as a result of as much as 1,000 feet of uplift during the interglacial interval prior to the Vashon advance. The valleys were then modified by the Vashon glacier and were drowned by submergence.

Hansen and Mackin (1949), Sceva (1957), and Crandell, Mullineaux, and Waldron (1958) confirmed that the valleys were cut into an overall fill, but they showed that the fill consisted of deposits of several different glacial and nonglacial episodes. No evidence was found to negate Bretz' hypothesis of pre-Vashon origin by fluvial erosion caused by uplift, and of only modification of the valleys by the Vashon glacier.

As a result of recent detailed work in and nes.r Seattle, however, Crandell, Mullineaux, and Waldron (1965) proposed that the Vashon Puget lobe formed at least one major trough in the lowland rather than merely modifying a preexisting valley into a trough. At Seattle, the deep Puget Sound trough is bounded by sea cliffs that expose a conformable sequence of nonglacial sediments of Olympia age and overlying Vashon advance outwash. Nonglacial sediments in the sea cliffs contain wood that ranges in age from 24,000 to 18,000 years; elsewhere in the city, wood from the nonglacial sediments is as young as 15,000 years (Mullineaux and others, 1965). The stratigraphic saquence shows that the locality of the present Puget Sound trough was a site of aggradation as much as several tens of feet above present sea level-thus near?y 1,000 feet higher than the floor of the modern troug'-during the Olympia Interglaciation. Moreover, aggradation continued to several hundred feet higher before the site was overridden by the ice. But the Puget Sound trough had already been fashioned in virtually its modern form when the glacier retreated; thus, the trough was formed under the ice and must lave resulted from ice scour. No regional uplift, fluvial erosion, or later submergence was required. Tho'igh the position of the modern Puget Sound trough might have been influenced by a previous valley, the trough was scoured by the Vashon glacier.

The manner of origin of the Puget Sound trough suggests that Duwamish Valley, once regarded as preserved from preglacial time and later as eroded by preVashon rivers, might alternately have been scoured by the Vashon Puget lobe. However, pertinent evidence along Duwamish Valley is meager and not adexuate to either prove or disprove such an origin. Some raising of the valley margins during Vashon time, as proposed by Willis, seems certain. But the troughs were not preserved from preglacial valleys, for remnants of the interglacial Puyallup Formation in both walls of the Puyallup-Duwamish trough show that the deep trough could not have persisted throughout Pleistocene time. Vashon Drift that was formerly thought to show that Duwamish Valley predated the Vashon adrance is largely subglacial material that could have kæen deposited under the ice long after its first advance. Stratified drift deposited in front of the ice is very limited in size and distribution along the valley and does not prove existence of more than small, local der"essions prior to the Vashon advance. Thus, no large Duwamish Valley formed by erosion can be shown to have existed 
during Olympia time. Finally, it cannot be demonstrated for Duwamish Valley (because of the absence of nonglacial sediments of Olympia age) that the site of the present valley was wholly or partly filled just before the ice advance, and that therefore the valley must have been produced by ice scour.

The available evidence does indicate that considerable ice erosion occurred. The very absence of nonglacial sediments of Olympia age suggests that any former valley along the same alinement must have been narrower than the present valley. If a former valley had been as wide, some remnants of nonglacial sediments should be found now in positions of former embayments or gullies in the valley walls. Second, aggradation to high levels along the Puget Sound at Seattle during nonglacial time indicates that any preVashon Duwamish Valley would not have been as deep as the postglacial Duwamish trough. Aggradation at Seattle records a high local base level, and a preVashon Duwamish Valley should also have been aggraded to about the same level. Thus, a Duwamish Valley during Olympia time that was either as wide or deep as the one is now seems very unlikely. Ice scour, at the very least, must be responsible for much of the width and especially for the depth of the postglacial trough. The question of whether the valley was first or principally excavated by a river or by the Vashon glacier and, therefore, whether it originated during a pre-Vashon episode or during the Vashon Stade is still not answered. But similarity of the Duwamish to the Puget Sound trough suggests strongly that the valley was excavated chiefly by scouring by the Vashon Puget lobe.

\section{DEVELOPMENT OF THE PRESENT DRAINAGE PATTERN}

The modern drainage pattern within the mapped area developed almost completely in late Pleistocene and Holocene time, though the general system of major rivers formed much earlier. The river system began to develop during the Miocene, as rocks in the Cascade Range and the Puget Sound lowland were folded along north-northwest-trending axes (Weaver, 1937). A new drainage system then became established along those structural trends (Mackin and Cary, 1965). By the end of Pliocene time, the Cedar, Green, and White Rivers probably all were flowing from the flanks of the rising Cascade Range northwestward across the Puget Sound lowland. The Cedar River at that time, however, was north of the bedrock barrier formed by the Newcastle Hills promontory (Mackin, 1941). Later, in Pleistocene time, the Cedar River was diverted into the lowland south of that promontory by the Puget lobe (Mackin, 1941). The Puget lobe also shifted the Green River so that it emerged from the Cascades several miles south of its preglacial exit (fig. 22; Campbell and others, 1915). Mackin and Campboll presented evidence that initial diversion of each river occurred before Vashon time.

Thus, each of the major rivers had, before Vashon time, temporarily or permanently been directed into the lowland south of the Newcastle Hills promontony. Within the mapped quadrangles, coarse detritus of Mount Rainier origin clearly shows the presence of a river, presumably the White River, heading on the volcano. These sediments crop out along the east wall of Duwamish Valley north to about Kent and along the west wall to about Tukwila (H. H. Waldron, onal commun., 1966). Gravels of central Cascade provenance, which crop out along all the valleys east of the Duwamish, record the presence of one or both of the Cedar and Green Rivers.

Although deposits in the mapped quadrangles show the presence of the major rivers during at least parts of pre-Vashon Pleistocene time, distribution of what deposits are exposed gives little evidence of specific river courses. Only the sediments from Mount Rainier appear in a fairly linear distribution, which suggests a valley fill. These sediments are almost all along the western part of the area, a distribution that suggests early existence of a pre-Vashon north-south valley much like the Duwamish of today. Each of the other rivers probably flowed across many different parts of the area from time to time and at other times probably did not even enter the mapped area. Diversion of the Green River at the mountain front obviously required the river to find a new route at least once, and each river might have taken a virtually new course across the lowland after each glaciation.

It is possible that the Cedar, Green, or White Rivers did not cross the mapped area immediately prior to the Vashon advance. No extensive Vashon outwash and no sediments of Olympia age at all have been identified along the present valleys of those rivers. Absence of such deposits and continuity of pre-Vashon sediments along present valley walls suggest that the rivers are not now following courses established in pre-Vasl on time. In the Cedar River valley, a small deposit of stratified drift suggests the possibility that some depression existed there just prior to the Vashon advance, but no other similar deposits indicate that the depression was extensive. Thick Vashon stratified drift nar Maple Valley and the low trough in the drift plain from there southwest to Auburn suggests a pre-Vashon depression along that route. However, fairly good exposures and apparent continuity of pre-Vashon formations in valley walls near Auburn indicate that the 


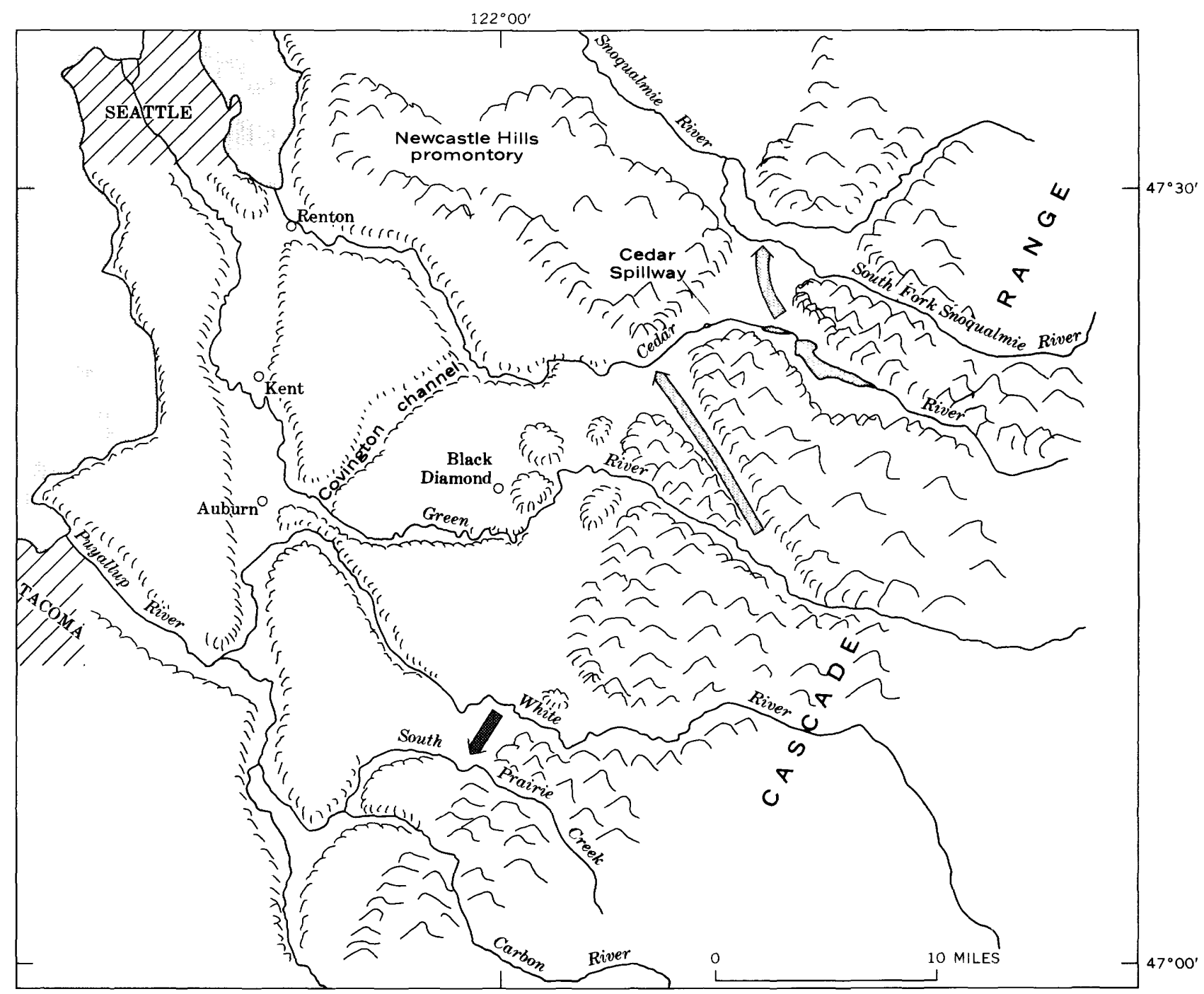

EXPLANATION

Abandoned preglacial courses of Cedar and Green Rivers near mountain front

Abandoned postglacial pre-Osceola course of White River

Figure 22.- Location of abandoned segments of preglacial courses of Cedar and Green Rivers near front of C $\varepsilon$ scade Range and of abandoned segment of postglacial pre-Osceola course of White River.

depression was not a major valley. That one or more rivers followed the route of the present Duwamish Valley seems possible, but supporting evidence is lacking.

\section{EFFECTS OF THE VASHON GLACIER}

Vashon Drift apparently smoothed over and concealed the drainage system over which the glacier advanced, and it constructed a new surface on which a consequent drainage developed. In general, the postglacial drainage was directed by the overall west to northwest slope of the drift plain that characterizes this part of the lowland. In detail, the drainage was controlled somewhat by the alinement of groundmoraine ridges, but mostly by the pattern of late glacial melt-water channels. The positions of the melt-water channels were in turn controlled by successive positions and configurations of the receding ice front.

As the Vashon Puget lobe retreated, first the White River and then the Green and Cedar Rivers became established in consequent courses along melt-water 
channels in the lowland. The White flowed southwestward along the mountain front in a channel that led to the Puyallup River by way of the present South Prairie Creek valley (fig. 22; Crandell, 1963). The White remained in that course until it was relocated by the Osceola Mudflow; thus, it did not flow into the mapped area in early postglacial time.

The Green River joined an ice-marginal river at the mountain front and flowed with it southwest for several miles. For the first few miles, the combined melt water and Green River flowed in a broad spillway between bedrock hills that probably had been cut by repeated ice scour and melt-water erosion during the Pleistocene (fig. 22). Southwest of that spillway, the stream was held along or near the front of the Puget lobe by the overall northwest slope of the drift plain. As the lobe retreated, the combined flow occupied several successively lower and more northward courses. It occupied several different channels in the Lake Tapps quadrangle (Crandell, 1963) and several in the southern parts of the Black Diamond and Auburn quadrangles before reaching the present route of the Green River. Further retreat of the Puget lobe along the mountain front eventually allowed the melt water to find a more northern course, so that the ice-marginal stream on longer joined the Green River at the mountain front. The Green River, however, was prevented from taking a shorter, northwest- or west-trending course to the lowland by the combination of the southwestward gradient of the melt-water channel floor and the barriers formed by bedrock hills and stagnant iceblocks.

The Cedar River was deflected, along with abundant melt water, through the Cedar Spillway (Mackin, 1941) into the lowland south of the Newcastle Hills promontory (fig. 22). The Cedar River and the melt water flowed from the spillway down the slope of the drift plain and across the Black Diamond quadrangle in front of the Puget lobe. The Cedar was probably only a small part of the large ice-marginal river that shifted gradually northwestward, forming, as it shifted, the broad outwash plain and later forming the valley train in the Covington channel. The Covington channel was abandoned when the river found a lower course to Duwamish Valley at Renton. By the time the river shifted to Renton, however, it may have consisted chiefly of the Cedar River itself rather than of ice-marginal melt water. At about the time of the shift, the ice-marginal river abandoned the Cedar Spillway to flow north of the Newcastle Hills promontory. Like the Green River, the Cedar was held in a southwest-trending spillway, even after ice retreat allowed the melt water to reach the lowland by a shorter, lower route.

Many minor streams on the drift plain also folloved melt-water channels, but others were controlled by the lineation of the Vashon ground moraine. Southeast of the Covington channel, the drift-plain streams almost all followed south- to west-trending melt-water channels that led away from the retreating ice front or laterally along it. Northwest of the Covington channel, the drainage is mostly consequent on drumlinized ground moraine. As a result, streams flow in a northnorthwest or south-southeast direction. The southeasttrending streams enter the Covington channel, where they join Big or Little Soos Creek and flow southwest to the Green River.

\section{POSTGLACIAL CHANGES}

Postglacial changes along the streams consist chiefly of entrenchment, distributary shifting on alluvial fons, and relocations caused by the Osceola Mudflow. Both the Cedar and Green Rivers probably became quickly entrenched after retreat of the Vashon ice. As they did so, each built a fan and delta into the marine emkayment that then occupied the Duwamish Valley. The Cedar River probably blocked off Lake Washington from the Duwamish embayment very shortly after ice retreat (Gould and Budinger, 1958). The lake then drained to the embayment by way of the Black River around the toe of the Cedar River fan. As the Cetar continued to build its fan, it flowed at various times to Lake Washington, to the Black River, and directly to Duwamish Valley. Such shifting has been prevented since 1916, when Lake Washington was lowered and the Cedar River channeled artificially into the lake.

The principal change caused by the Osceola Mudflow was the deflection of the White River to Duwamish Valley at Auburn, evidence for which is found along both the old and new courses of the river (Crandell, 1963). Exposures along the modern White River valley southeast of Auburn indicate that no major valley existed there prior to inundation of the drift plain by the Osceola. No alluvium of the White River underlies the mudflow along that route, and the mudflow nowhere is seen as a thick valley fill. Insteac, it occurs as a thin broad deposit over the surface of the drift plain. In the valley of South Prairie Creek, in contrast, the mudflow overlies coarse gravels of Mcrut Rainier provenance. The only possible source for the alluvium, according to Crandell (1963), was the White River, for South Prairie Creek does not head on the volcano. This and other evidence led Crandell to conclude that prior to Osceola time the White River flowed through the South Prairie Creek valley and that it 
was later relocated to its present position by the mudflow.

After diversion to Duwamish Valley at Auburn, the White River entrenched itself and built a fan and delta in Duwamish Valley that rapidly raised the valley floor above sea level. As Willis (1898c) pointed out, the alluvial cone of the White River extended from the end of the Puyallup Valley at Tacoma to Elliott Bay at the end of Duwamish Valley at Seattle. The river flowed alternately north and south on its fan until 1906, when during a flood the main flow shifted from the northern to a southern distributary. Since that time, the river has been held artificially in the southern part.

The Osceola not only relocated the White River but also diverted many small streams on the drift plain. One such stream, Newaukum Creek, enters the Lake Tapps quadrangle about 2 miles south of the Black Diamond quadrangle along a southwest-trending meltwater channel. The creek probably once continued to the Puyallup Valley in that channel. But the channel was overwhelmed by the Osceola, which directed Newaukum Creek north to flow down the gradient of the mudflow to the Green River in the Black Diamond quadrangle.

\section{RIVER GHARACTERISTICS}

Each of the three major rivers flows across the mapped area on a fairly smooth gradient, and each may be at or nearly at grade within the mapped quadrangles. The channel and flood-plain characteristics of the closely adjacent Green and White Rivers east of Duwamish Valley, however, are markedly different, even though these rivers formerly joined in Duwamish Valley at Auburn. The two rivers are similar in that they carry about the same discharge, they both rise in the Cascade Range and flow across the lowland in valleys cut into the drift plain, and until recently they both had a common local base level at their confluence. Yet above the former junction at Auburn, they differ conspicuously in size of bedload carried, gradient, channel patterns, migration habits, and flood-plain characteristics. There is also a conspicuous contrast between channel and flood-plain characteristics of the rivers east of Duwamish Valley and those in Duwamish Valley itself.

\section{GREEN RIVER}

Green River discharge as measured near Auburn averaged about $1,330 \mathrm{cfs}$ (cubic feet per second) between 1936 and $1960 .^{1}$ The maximum recorded dis-

\footnotetext{
${ }^{1}$ Data on river discharge used in discussion, unless otherwise stated are taken from Water Supply Papers entitled "Surface Water Supply of the United States, Part 12. Pacific Slope Basins in Washington and upper Columbia River basin," published annually (to 1960) by the U.S. Geological Survey.
}

charge during the same period was 28,100 cfs in 1959. The gradient along the river from the east boundary of the Black Diamond quadrangle to Auburn decreases from about 20 to 5 feet per mile (fig. 23 ); the material that composes the bedload along the same stretch of the river decreases in median grain size from about 4 to 2 cm. (See p. 58.)

The Green River in its valley east of Auburn migrates primarily by cutting on the outside of meanders. Meander migration is rapid, and braiding is common along only two stretches of the river. These two are the localities where channel deposits are broad (p. 58), just downvalley from the mouths of New. aukum and Big Soos Creeks. Below Newaukun Creek, comparison of the Auburn topographic map, made from aerial photographs taken in 1943, with field observations in $195 \%$ shows shifting of the channel at one place as much as 1,500 feet in 14 years. Below Pig Soos Creek, comparison of the map with aerial photographs taken in 1953 shows migration of about 500 feet in 10 years. Elsewhere on the valley floor, however, presence of large trees and old farms indicates that the river does not migrate nearly that rapidly over the flood plain as a whole.

\section{WHITE RIVER}

White River discharge measured at Buckley, 15 miles upstream from Auburn, averaged about 1,40C cfs for 26 years of record before 1960 , an average very close to that of the Green River. Some $600-900 \mathrm{cfs}$ was diverted from the White River just below Buckley, however, and did not pass through the Auburn quadrangle. The average discharge at a station bolow the diversion over a period of 15 years was about $620 \mathrm{cfs}$. The maximum recorded discharge of the White between 1928 and 1960 was only about $17,000 \mathrm{cfs}$. However, an unrecorded maximum was estimated from flood marks at the gaging station to have reached about $28,000 \mathrm{cfs}$ in 1933 , about the same as the maximum recorded flood along the Green River.

The southern distributary in which the White River now flows near Auburn has almost exactly the same length and gradient as did the northern distributary that formerly joined the Green River at Auburn; it is assumed that the White had approximately the same characteristics in both distributaries. The gradient of the White River from the point at which it enters the Auburn quadrangle to where it leaves decreases from about 30 to 20 feet per mile (fig. 23). The median diameter of bar gravels along the same river reach decreases from about 7 to $5 \mathrm{~cm}$. (See p. 59.) The White River thus carries a coarser load and maintains a steeper slope along a reach like the one above its former 
junction with the Green River than did the Green River above the same junction.

The coarser (and probably more abundant) load of the White River likely is due to material acquired just upstream from the Auburn quadrangle, near the Cascade mountain front and in the Puget Sound lowland, rather than high in the Cascade Range. The river gradient near Buckley, for example, is steeper than it is 10-20 miles farther upstream. The coarse detritus probably is derived mostly from the Osceola Mudflow and from a large mass of drift in the White River valley at approximately the mountain front. The source of the material at the mountain front is a terminal moraine of the Puget lobe (Mackin, 1938). In addition, some coarse material on the White River flood plain may be lag gravel, concentrated as the river cut down through the drift plain. The Green River, in contrast, has no comparable nearby sources of abundant coarse detritus. It derives very little load from the Osceola Mudflow; the analogous terminal moraine in its valley is farther from the mapped area; and lag gravel concentrated as the river cut down throngh drift-plain formations has been buried by subsequent aggradation.

The relatively steep slope of the White River as compared with that of the Green is regarded as due to the coarser and probably more abundant load that is supplied to it just upstream from the Auburn quadrangle. Other things being equal, transportation of the coarser load would require a higher velocity (Mackin, 1948), which along the White River likely is provided by maintenance of a steeper slope.

The channel of the White River in its valley east, of Auburn is conspicuously braided, and the flood p]ain shows that prior to artificial channel control the river moved rapidly across the valley floor. Comparison. of the topographic map with aerial photographs taken in 1953 shows that the river has shifted as much as 1,000 feet in several places within 10 years. The channel shifts by sweeping across the flood plain in migrating
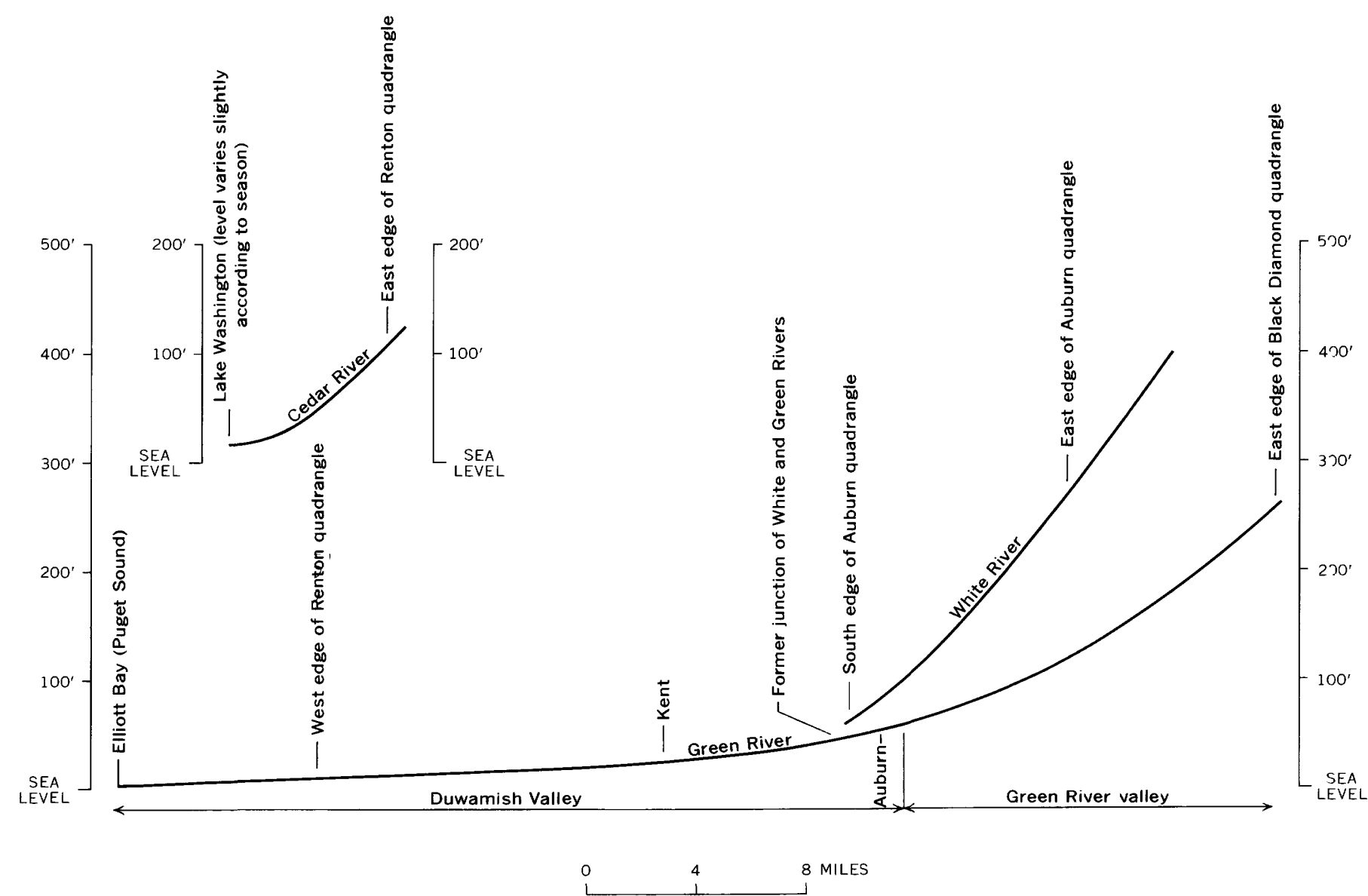

Figure 23.-Generalized profiles of segments of the White, Green, and Cedar Rivers in mapped area. From U.S. Geological Survey Renton, Auburn. Maple Valley, Black Diamond, Buckley, and Summer quadrangles, scale 1: 24,000, and U.S. Army Corps of Engineers flood profiles of the Green River. Datum is mean sea level. 
meanders as well as by braiding. From the amount of the flood plain covered by fresh channel deposits that are nearly bare of vegetation, it seems certain that the White River moved across its flood plain as a whole much more rapidly than did the Green River. The more rapid migration may also be a result of the load supplied to the White River just upstream from Auburn quadrangle. A coarse load and high velocity are factors that lead to rapid lateral migration (Mackin, 1948).

\section{IN DUWAMISH VALLEY}

Stream gradient, bedload size, and rate of progressive channel migration along both the Green and White Rivers are distinctly less in Duwamish Valley than in the Green and White River valleys. Along the White River south of the Auburn quadrangle, natural changes are somewhat masked by several artificial factors, including the effect of reintroduction of diverted water to the river without bedload (Crandell, 1963, p. A55). North from Auburn, however, grain size and gradient decrease notably down the distinct White River fan and along the present channel of the Green River (fig. 23). The size of most bedload particles has decreased to that of sand where the Green River leaves the mapped area at Tukwila, and the gradient of the river has decreased to about 1 foot per mile at that point. The river does meander in Duwamish Valley north of Auburn, but cutting along the outside of the meanders, especially north of Kent, is slow. Levees that form on both sides of the river along the meanders, and peat layers interbedded in the overbank materials, provide evidence that the river does not shift rapidly by progressive migration of meanders. Another method of channel migration, that of avulsion or the shifting of whole segments of the channel at a time, appears to be much more important. Two long segments of abandoned channel that are similar in form to the present channel indicate that the river shifted extensive portions of its course at a single time rather than by progressive lateral migration.

\section{FLOOD-PLAIN DEVELOPMENT}

Flood plains of the Green and White Rivers within the mapped area are made up of widely varying proportions of the materials defined as channel deposits (deposits of lateral accretion) and of overbank material (deposits of vertical accretion) (Fenneman, 1906; Mackin, 1937; Jahns, 1947). The importance of overbank material in the formation of flood plains has been questioned by Wolman and Leopold (1957, p. 106), who concluded that for average flood plains "the proportion of overbank material appears to be small." The flood plains of the Green and White Rivers in some places include very little overbank material; in other places they have more significant proportions cf overbank material, and in still other places they are composed largely of overbank deposits. The origin of the coarse channel gravel is easily recognizable, but, as Wolman and Leopold pointed out, the origin of the finer deposits may not be so evident. Deposits described as orerbank sediments herein are identified by their occurrence on natural levees or by the presence $\mathrm{cf}$ interbedded peat-material that should have been removed if the channel had migrated laterally past that site.

The flood plain of the White River east of Auburn serves as a local example of a flood plain with very little overbank material. The rate of channel migration there is rapid compared with the rate of orerbank deposition; consequently, the flood plain consists

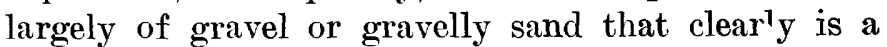
channel deposit.

The flood plain in the Green River valley contains considerably more fine material than that in the White River valley, but only a small proportion of it can be identified as overbank deposits. Channel migration over the whole flood plain is slower than along the White, and only a small part of the material at the surface is clearly channel gravel and sand. Finer materials that are probably of overbank origin, which are thin in the Black Diamond quadrangle, incroase in thickness and volume westward toward Auburn. Although not certain, it seems likely that the thick silt and clay and peaty sands near Auburn are largely of overbank origin.

In Duwamish Valley, overbank material increases in proportion to channel deposits northward along the former course of the White River until, north of Kent, nearly the entire valley floor is formed of overbank sediments. Overbank materials are relatively trick and extensive there because the river migrates mostly by avulsion, rather than by meandering, and thus it does not continuously rework the flood plain. Levees on both sides of the channel and presence of peat interbedded with fine-grained sediments between channels show that the active channel remains in place for long periods of time compared with the channels in the Green or White River valleys east of Auburn. Modern conditions in Duwamish Valley north of Kent apparently are similar to those in the Puyallup Valley in the Lake Tapps quadrangle, where remnants of volcanic mudflows on the flood plain show that the river has remained in a narrow course for at least the last 500 years (Crandell, 1963, p. A55).

Thus, flood plains along the Green and Whita Rivers exhibit a wide variety in proportion of channel and 
overbank materials, from one river to another and also along the same river over distances of as little as 10 miles. Presumably all gradations exist between flood plains composed predominantly of channel deposits and those consisting chiefly of overbank material, depending on local conditions that determine the rate and type of channel shifting (Mackin, 1948, p. $503 ; 1956)$. Where the river migrates rapidly, the flood plain is composed mostly of channel deposits; where it shifts slowly and chiefly by occasional sudden diversion, the flood plain may be composed largely of overbank sediments. Locally, the flood plain in the White River valley east of Auburn illustrates the type composed mostly of channel deposits, and that in the northern part of Duwamish Valley illustrates the type dominated by overbank material.

\section{STRUCTURE}

\section{LOWER TERTIARY ROCKS}

Regional deformation in the lower Tertiary bedrock produced major upwarps and downwarps with axes 10 miles or more apart (Weaver, 1916) and numerous smaller folds and faults. According to Weaver, the major structural features were dereloped along a regional west-northwest trend and extended across what are now the Puget Sound lowland, the Olympic Mountains, and the Strait of Juan de Fuca. Mackin and Cary (1965) suggested that the west-northwest alinement of major streams in the Cascade Range indicates that the same regional trend extends virtually through the Cascades. Vine (1969) recently emphasized that a west-northwest trend of gravity contours exists north and east of Renton. He also proposed that a hinge line having that same trend, which separates areas of markedly different thickness of Eocene sediments, was a major structural element as early as Eocene time. He pointed out, however, that in detail, structural elements do not faithfully follow a regional west-northwest trend. The Newcastle Hills promontory, which extends from the Cascade Range west-northwest into the Puget Sound lowland (fig. 22), is described as a major upwarp by Weaver (1916). Rocks within this upland illustrate the many smaller folds and faults that are apparently related to the regional orogeny (Weaver, 1916; Warren and others, 1945; Vine, 1969). These smaller folds and faults within the Newcastle Hills upland both parallel and diverge widely from Weaver's postulated regional trend.

In the report area, the principal structural features known are small anticlines and synclines whose axes are generally half a mile to a mile apart and a few faults. The presence of bedrock outcrops far out in the lowland at Renton, in contrast to their absence to the south, is in accord with Weaver's hypothesis that this area lies along the flank of the Newcastle Hills upwarp. At Renton, the observed folds generally follow the postulated 'regional west-northwest trend but locally the strikes diverge considerably from it. Near Black Diamond, in contrast, the principal folds have a markedly different trend, slightly east of north. This northerly trend is not merely a local divergence from a regional trend, for similar folds trend north along the Cascade mountain front to the north, east, and south of Black Diamond (Wearer, 1916; Warren and others, 1945 ; Gard, 1968; Vine, 1969).

The bedrock structure in the Renton and Black Diamond districts has been studied repeatedly, chiofly in the search for coal. Detailed studies by Willis (1886, 1898a), Evans (1912), Weaver, (1916, 1937), and Warren, Norbisrath, Grivetti, and Brown (1945) all made use of exposures of bedrock in operating mines as well as those on the surface. Figure 24 , which summarizes structure information in the Renton district, has been assembled largely from these earlier reports.

Most folds exposed near Renton are asymmetric anticlines and synclines whose limbs dip from about $10^{\circ}$ to $65^{\circ}$. They are somewhat irregular; either their axes curve or they are offset by faults, and some apparently die out along the strike. Correlation of features across even a mile or two of alluvium is uncertain. The principal folds are two anticlines and two synclines, the northernmost of which is the Renton anticline of Evans (1912) (fig. 24, this report). The Renton anticline extends from northwest to southast Renton, plunging gently southeast; dips on its limbs range from a few degrees to about $30^{\circ}$. The adjacent syncline to the south, the Talbot syncline of Evans (1912), is exposed on the east wall of the Duwamish Valley. Its south limb dips about $65^{\circ}$, whereas its north limb dips only about $10^{\circ}$. East of sec. 19 , its position is not known, but it may curve northeast and cross the Cedar River in sec. 21 (fig. 24). Northwestward, it is largely hidden under alluvium, but its probable position is indicated near the quadrangle boundary by exposures on a small hill in Duwamish Valley in sec. 24 (fig. 24). The crest of the next anticline south of the Talbot syncline, here called the Tukwila anticline, is hidden under alluvium, but its approximate location is indicated by exposures in the small hill in Duwamish Valley in sec. 24 and in the west wall of the valley at Tukwila in secs. 23 and 24 . To the sontheast, its north limb is exposed along the east wall of Duwamish Valley but its crest and south limb are not and apparently have been offset alorg a 

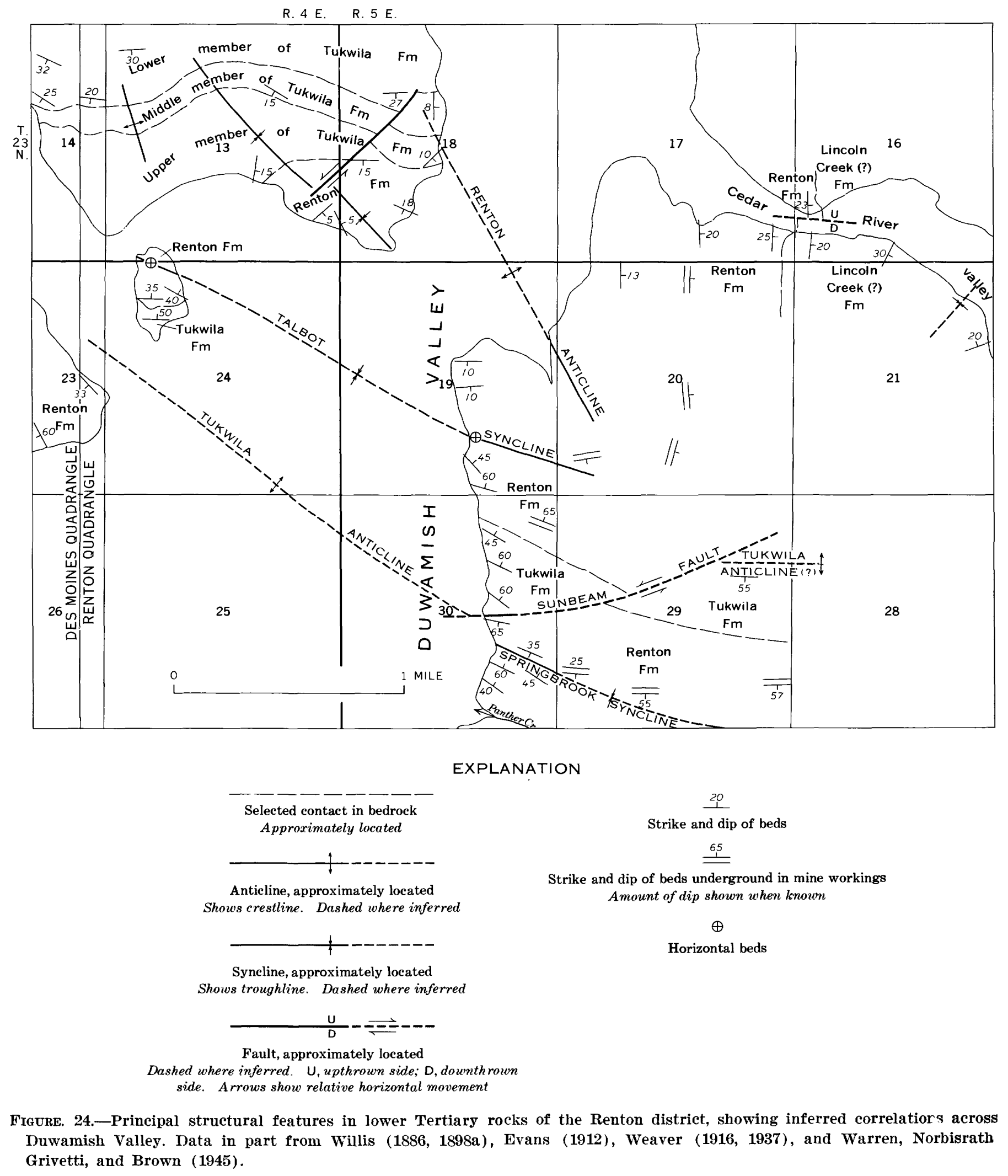

Frgure. 24.-Principal structural features in lower Tertiary rocks of the Renton district, showing inferred correlatiors across Duwamish Valley. Data in part from Willis (1886, 1898a), Evans (1912), Weaver (1916, 1937), and Warren, Norbisrath Grivetti, and Brown (1945). 
fault. Another syncline, here called the Springbrook syncline, lies south of this fault and is also exposed along the east valley wall.

The existence of another anticline, about 1,000 feet south of the Springbrook syncline (Warren and others, $1945)$, could not be confirmed because the key outcrops along Panther Creek (fig.. 24) are so poor that the attitude of the beds there could not be determined. Willis (1898a), however, indicated that a lignite bed in the Panther Creek area dipped north rather than south as shown by Warren, Norbisrath, Grivetti, and Brown (1945). If the dip is actually to the north, no anticline is indicated just north of the Panther Creek exposures.

A few other folds are indicated by the outcrop pattern and by isolated outcrops. The curve of the outcrop of the middle member of the Tukwila Formation in northwest Renton suggests that in that locality a small syncline and anticline lie across the southwest limb of the Renton anticline. Along the Cedar River east of Renton, reversal of dips in the Lincoln Creek(?) Formation indicates the presence of a northeast-tiending syncline.

Two faults in the Renton district are large, but most known faults are small, with only a few feet displacement. The largest, here called the Sunbeam fault, trends eastward across the Duwamish Valley wall in sec. 30 (fig. 24 ; Warren and others, 1945). It brings the lower member of the Tukwila Formation up adjacent to the Renton Formation, separated from the Renton along the valley wall by only a small intrusive body. The fault apparently extends east-northeast, north of the outcrops of the Tukwila Formation in sec. 29. This fault probably is responsible for the reversal of dip in the Tukwila Formation between secs. 30 and 29 ; the axis of the Tukwila anticline south of the fault apparently has been shifted to the northeast. If so, the Sunbeam fault has at least 3,000 feet of left-lateral strike-slip displacement. Warren, Norbisrath, Grivetti, and Brown (1945) show a fault at the southeast end of the Sunbeam mine in sec. 29 as a part of this fault zone.

The second large east-trending fault has been inferred by Warren, Norbisrath, Grivetti, and Brown (1945) to underlie alluvium in the Cedar River valley. The Renton Formation strikes directly across the valley, yet the top of the formation on the north side is about 1,000 feet farther east than on the south side. A strike-slip fault with about 1,000 feet of the rightlateral displacement or a high-angle fault with the south block downthrown about 500 feet could account for the apparent displacement of the formation top.
Only one other fault, which is in northeast Renton, has been mapped in the Renton district in this investigation. The many small faults observed and shown on mine maps and in earlier reports are typically highangle faults, and most are reported to be normal.

Near Black Diamond, the structure is dominated by a series of anticlines and synclines that trend generally north and are best exposed in the Green River valloy (Evans, 1912). The westernmost known anticline and syncline of this group lie about 1 mile apart in the Black Diamond quadrangle (Mullineaux, 1965c). T? 9 anticline, the Black Diamond anticline of Evans (1912), is asymmetric and plunges north where it crosses the river; beds on its east limb dip about $45^{\circ}$, and those on its west limb about $20^{\circ}$, indicating a westward dip of its axial surface. Between the Green River and the town of Black Diamond, this fold is interrupted by a small transverse syncline and by a fanlt (Willis, 1898a), which is the Franklin fault of Evans (1912). North of the fault the plunge reverses and the fold rises northward under the town; it then reverses again and plunges northeastward as the $\mathrm{fc}^{\mathrm{l}} \mathrm{d}$ axis curves just north of the town. At Black Diamord, the crest of the fold has been offset to the east and cut of the Black Diamond quadrangle. The rocks with in the quadrangle lie on its west limb in a small wertplunging transverse anticline whose core contains the oldest beds exposed within the quadrangle boundarios. A north-trending syncline west of the Black Diamond anticline is indicated in the Green River valley by reversal of dips between isolated exposures, which also indicate that the axis of the fold plunges south (Mullineaux, 1965c).

Exposures, drill records, and mine records show th at the bedrock near Black Diamond is broken by many small faults, but only one major fault is known in the quadrangle. It is the Franklin fault or fault zone, which was discovered during early mining and geological explorations (Evans, 1912). The Franklin is a strike-slip fault that passes just south of the town of Black Diamond and shows about 1,000 feet of rightlateral displacement along a west-northwest trend (Warren and others, 1945; Vine, 1969). Most smaller faults observed and reported from the mines are high angle and normal. Anderson (1959), however, srggested by a cross section of the rocks near Black D:amond that reverse faults are also common.

From evidence in the mapped area, the major deformation can be dated only as younger than upper Eocene and lower Oligocene Puget Group rocks near Black Diamond and older than the overlying upper Miocene Hammer Bluff Formation. Major regional diastrophism in this region, according to Wearer 
(1937), occurred in late Miocene time, after deposition of the Oligocene and Miocene rocks that crop out near Issaquah. Strong deformation, however, was not limited to one episode but occurred at several times during the Oligocene and Miocene and at various localities (Fiske and others, 1963; Gard, 1968; Vine 1969). Thus, folding of the lower Tertiary rocks of the report area might have occurred at any time between early Oligocene and late Miocene time.

\section{UPPER TERTIARY ROCKS}

The upper Tertiary Hammer Bluff Formation shows minor deformation that occurred after the folding of the lower Tertiary bedrock. Exposed Hammer Bluff lacustrine clays and lignite show dips as high as $10^{\circ}$; dips as high as $25^{\circ}-30^{\circ}$ have been reported in the formation by Glover (1941). It is not certain how much of the steeper dips is due to deformation and how much represents initial dip. Attitudes in this formation vary considerably within individual exposures, and their determination is complicated by numerous landslides. However, near Hammer Bluff, observed dips were consistently to the north and northwest on the north side of the river and to the southwest on the south side. Half a mile east of Hammer Bluff, the formation dips gently eastward. Glover (1941), measured northwest dips at Hammer Bluff and a northeast dip only a quarter of a mile to the southeast. He pointed out that there apparently is a gentle arch or anticline in the formation at the Hammer Bluff locality (Glover, 1941, 1936). Although faults have been found in deposits in the Lake Tapps quadrangle that are correlated with the Hammer Bluff Formation (Mullineaux and others, 1959), none have been observed in the Hammer Bluff itself.

The deformation of the Hammer Bluff Formation apparently does not represent recurrent folding along the structural features shown in the bedrock, because the arch in the Hammer Bluff beds lies over a synclinal trough in the bedrock. Gentle dips are common in various deposits that have been correlated with the Hammer Bluff Formation (Glover, 1941; Mullineaux and others, 1959); thus, the deformation apparently was widespread.

\section{PLEISTOCENE DEPOSITS}

Pleistocene sediments generally are nearly flat lying and are little deformed, but they show an apparent gentle overall tilt to the west, a few small folds, and numerous small faults. The tilt to the west is best shown by the Pleistocene sediments exposed along the Green and Cedar River valleys. Along the Green River, the lower(?) Pleistocene Orting(?) Drift dips gently west and passes under the middle(?) Pleistocene intermediate drift. At one place, Orting( ?) lacustrine beds that $\operatorname{dip} 2^{\circ}-3^{\circ} \mathrm{W}$. are well exposed along the river for several hundred feet. The overlying intermediate drift also appears to dip gently west, but at only abc'tt 30-40 feet per mile. Along the Cedar River valley at Renton, thin nonglacial lacustrine beds that dip as much as $5^{\circ}$ to the northwest can be traced for more than 1,000 feet. The general westward dip of Pleistocene sodiments along the Green and Cedar Rivers is inferred to be a result of broad tilting associated with relative subsidence of the Puget Sound lowland, the central part of which is west of the mapped area. Along the Cedar River, the effects of local tectonic deformation or unequal compaction might have been superimposed on the overall gentle dip.

Small folds have been seen in all mapped Plisistocene formations except the Vashon Drift. Dips that exceed a few degrees occur mostly in foreset beds and collapsed strata in glacial drift. Elsewhere, dips are low, and very few exposures are large enough to show whether the dipping sediments occur in small folds or fault blocks. In a few places, series of small folds have been observed. Along the White River, well-expos'd lacustrine beds in the intermediate drift are folded into a series of anticlines and synclines only a few tens of feet across. Although the origin of most dips in the Pleistocene sediments is obscure, it seems likely that one of the most common causes is differential settlement over irregular topography and that othar causes are subaqueous sliding and ice shove.

Faults that are common in the Pleistocene deposits typically are high angle and small. The largest known fault shows only about 30 feet of displacement, and most faults show only a few inches to a foot or two. The largest fault, which is exposed along the Green River (Mullineaux, 1965c), is downthrown about 30 feet on the east side. It cuts through $200 \mathrm{fee}^{t}$ of Orting(?) glaciolacustrine and fluvial sediments and is not associated with smaller faults. Most smaller faults occur in clusters in stratified drift, but some cut through peat-bearing nonglacial sediments. Probably ice shove or ice melting and subsequent collapse are responsible for most small faults in drift units, but larger faults that occur alone seem to indicate a tectonic origin. No faults were seen that cut entirely through the Vashon Drift.

\section{SUMMARY OF GEOLOGIC HISTOPY}

The stratigraphy and geologic history of th area of the Renton, Auburn, and Black Diamond quidrangles and nearby parts of the Puget Sound lowland are summarized in figure 25 and table 5 . The following inter- 


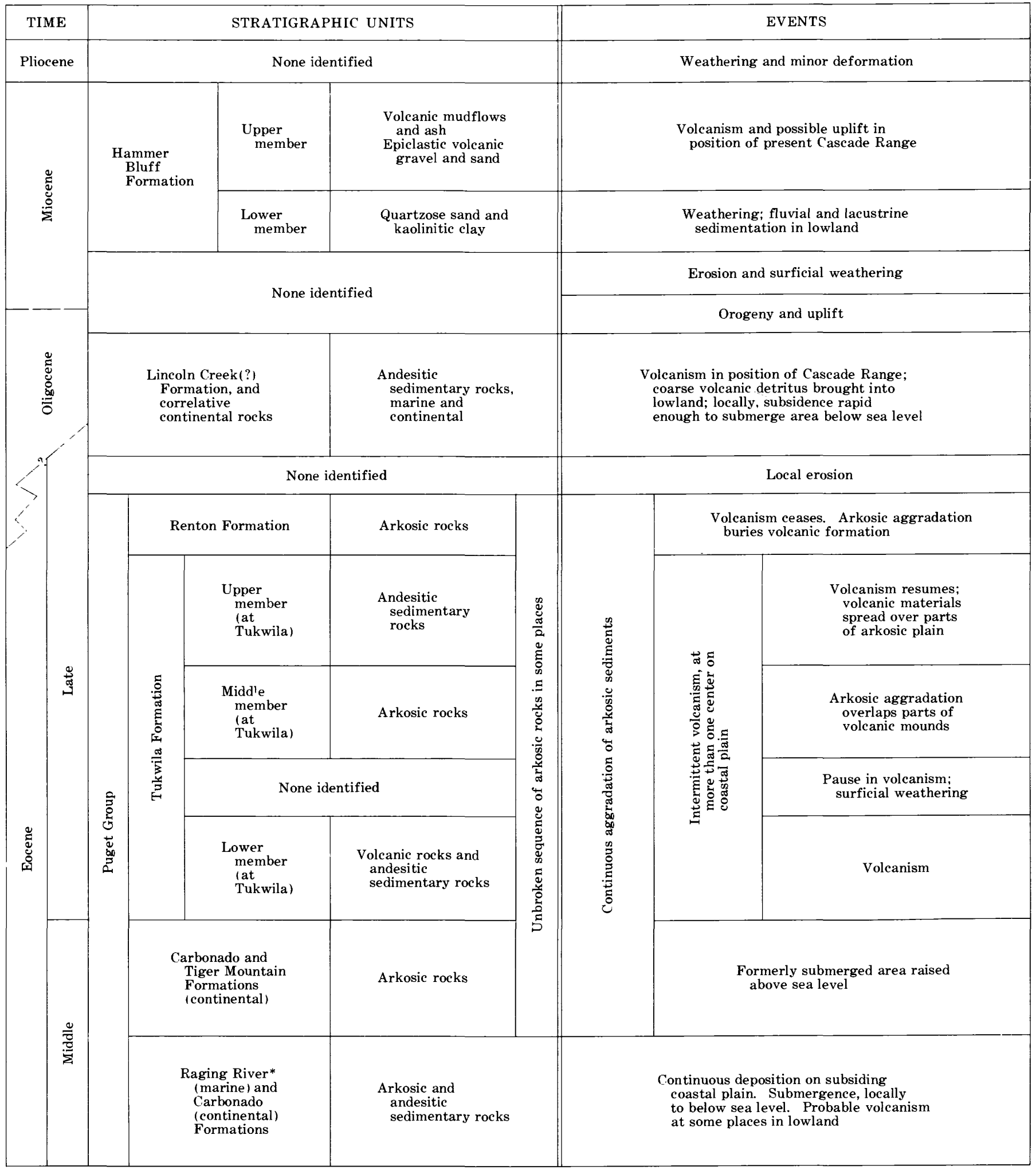

* Not part of Puget Group

Figure 25.-Summary of Tertiary stratigraphy and geologic history in the Puget Sound lowland southeast of Seattle. Data in part from Waldron (1962), Vine (1962a), and Gard (1968). 
TABLE 5.-Summary of Quaternary stratigraphy and geologic history in Puget Sound lowland southeast of Seattle [Modified from Crandell (1963, table 4)]

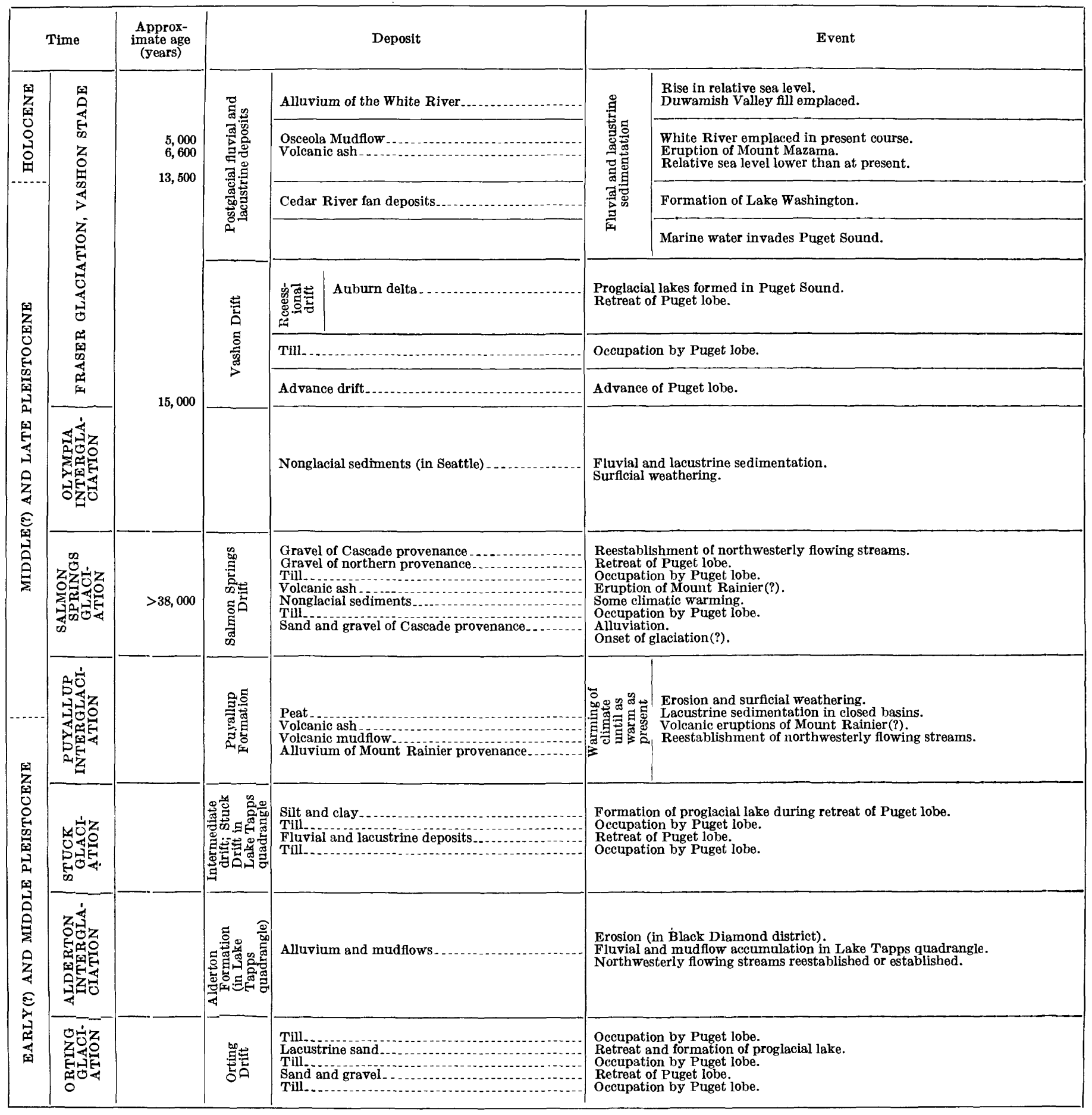


pretation of history is based on geologic evidence in the three mapped quadrangles, on the literature cited previously, and in part on as-yet-unpublished results of U.S. Geological Survey investigations in adjacent areas. The known history of the area starts in the Tertiary with the oldest rocks exposed in this part of the lowland, which are of middle Eocene age.

\section{TERTIARY PERIOD}

In middle and late Eocene time, the Puget Sound lowland was part of a coastal plain in a subsiding basin or geosyncline. Sediments accumulated in the basin at about the same rate as it subsided. The basin fill consisted mostly of slowly and continuously deposited arkosic sediments of the Puget Group derived from the east and locally of more rapidly but intermittently deposited volcanic rocks and sediments of the Tukwila and similar formations derived from eruptive centers on the coastal plain. The plain extended from south of Washington north at least as far as Renton and Seattle; it extended east at least to the position of the present Cascade Range and locally farther, into what is now central Washington. No high mountain range like the Cascade Range of today existed in Eocene time, and the coastal plain may have covered a large part of the area of the present central Cascades. The climate during middle and late Eocene time was subtropical or temperate.

During part of the middle Eocene, a marine embayment in western Washington reached north as far as Seattle and, at that latitude, east as far as Tiger Mountain. Twenty-five miles south of Tiger Mountain, however, it apparently did not extend as far east and did not reach Carbonado. Andesitic and arkosic sediments were deposited in the marine embayment in the vicinity of Seattle and Tiger Mountain. Subsequently, the sea retreated and continental sediments of the Puget Group were deposited on the marine sediments.

In late Eocene time, volcanic activity either began or became more intense at eruptive centers on the coastal plain, one of which was somewhere east of Renton near Issaquah. Volcanic rocks and sediments, the Tukwila Formation, derived from this center, accumulated rapidly. These deposits raised the surface of the coastal plain near Renton higher than the aggradational surface of the arkosic sediments. Rocks in the Tukwila Formation record both explosive and quiet eruptions during this part of the period. Deposition of the volcanic detritus was intermittent; during pauses in deposition, exposed sediments in some places were weathered to clay and then were overlapped and covered by continuously aggrading arkosic sediments. Later, these arkosic sediments were covered by more volcenic detritus during another episode of rapid accumulation of Tukwila volcanic material. Farther from the eruptive center, near Black Diamond, aggradation of arkosic sediments continued virtually undisturbed by the volcanic activity.

After volcanism ceased in Tukwila time, arkosic sediments of the Renton Formation overlapped and covered the Tukwila Formation. During depositior of the Renton, the area of the southeastern part of the Puget Sound lowland still was mostly a continental coastal plain of low relief near sea level. The p!ain probably was similar to the surface of large mocern deltas; bedloads of sand were carried by the rivers that crossed the plain, and the areas between the rivers were occupied by swamps, lakes, and lagoons. The rivers aggraded and shifted back and forth across the plain as it subsided, and they deposited a sequence of interbedded sand, silt, clay, and peat more than 2,000 feet thick.

Near the end of Eocene time, volcanic activity and perhaps uplift in the position of the present Cascade Range cut off the area of the Puget Sound lowland from the source of arkosic sediments, and deposition of the Renton Formation ended. A volcanic mountain range formed east of the position of the present lowland. Volcanic detritus from this range was brorght into the basin, and deposition of the Lincoln Creek (?) and correlative continental formations began. Rivers became swifter or increased in volume enough to carry boulder gravel nearly to Black Diamond and pebble gravel as far west as Renton. At the same time, the rate of subsidence at Renton increased markedly; although the rate of deposition probably also increased, the Renton district was submerged to several hundred feet below sea level during deposition of part of the Lincoln Creek (?) Formation. At Black Diamond the coastal plain remained above sea level, but its character had changed from that of Renton time. During Lincoln Creek(?) time the coastal plain was narrower, it was crossed by swifter, more rapidly aggrading streams, and swamps on it were ephemeral or absent.

Deposition of marine andesitic sediments like those of the Lincoln Creek(?) continued in the region near Renton, at least intermittently, through much of the Oligocene Epoch. In middle or late Miocene time, after rocks in western Washington had been folded and faulted, the area of the Puget Sound lowland was raised above sea level. After this deformation and before the end of Miocene time, the region was eroded to a surface of low relief, and the rocks were weathored and leached. 
In late Miocene time fluvial and lacustrine sediments of the Hammer Bluff Formation were deposited near Black Diamond. The lithologic change upward in the Hammer Bluff to andesitic sediments derived from Tertiary andesitic rocks of the Cascade Range from the sediments that were derived locally from arkose suggests that some uplift of a nearby range to the east occurred in late Miocene time. However, the range did not become high enough or continuous enough to be a climatic barrier, as it is at present.

During Hammer Bluff time, rolcanic eruptions in the Cascade Range produced andesitic rocks that are rich in green hornblende and notably different from most rolcanic rocks in the Cascades. Detritus from these eruptive centers was deposited along both the east and the west flanks of the range. It forms much of the upper Miocene and lower Pliocene Ellensburg Formation in central Washington and occurs in several upper Miocene formations along the west side of the Cascade Range from Hammer Bluff southward.

During late Miocene or Pliocene time, the Hammer Bluff Formation was mildly folded. In addition, it was exposed to weathering during much of Pliocene time.

\section{QUATERNARY PERIOD}

In Pleistocene time, the Puget Sound lowland repeatedly was occupied by a lobe of the Cordilleran glacier, which advanced southward from British Columbia. The oldest glaciation recognized in the lowland, the Orting, may have occurred in early Pleistocene time (table 5), but its precise age is not known. The Puget lobe of Orting age advanced to the front of the Cascade Range southeast of Seattle and probably extended several tens of miles south of Seattle. The glacier advanced across the Black Diamond district two or three times, retreating an unknown distance between advances. Gravel in the drift contains stones probably derived from an ancestral Mount Rainier, indicating that such a volcano would have been in existence before the end of the Orting Glaciation.

The Alderton Formation was deposited on the Orting Drift during the interglaciation that followed the deposition of the drift. Pollen studies show that the climate during part of Alderton time was as warm as it is in the Puget Sound lowland today. The Alderton Formation attests to the fact that streams carried volcanic detritus derired from Mount Rainier more than 30 miles northwest of the volcano into the Lake Tapps quadrangle. However, no Alderton deposits are exposed in the Renton, Auburn, and Black Diamond quadrangles to show that the Alderton reached as far north as the mapped area.
The Stuck Glaciation followed the Alderton Interglaciation. Probably at some time during this episode, the drift formation termed "intermediate" was deposited in the area between Auburn and Black Diamond by the Puget lobe. The lobe advanced across the mapped area least twice and deposited two widespread sheets of clayey till and an intervening 100 feet of stratified sediments.

The climate during part of the succeeding Puyallup Interglaciation was again as warm as it is in the lowland now. Streams in the southeastern part of the lowland were reestablished in northwesterly courses, and they carried sediments derired from Mount Rainier at least as far as Kent, about 50 miles northwest of the mountain. Allurium and mudflows derived from Mount Rainier, together with lacustrine silt and clay, rolcanic ash, and peat, were deposited in the lowland during the Puyallup interval. In places these deposits were eroded and subjected to a long period of weathering during a later part of the long P'yallup Interglaciation.

Early in the Salmon Springs Glaciation, which followed the Puyallup interval, and before the Puget lobe reached the mapped area, much of the region near Auburn was covered with gravel and sand deposited by rivers heading in the Cascade Range. The Puget lobe then, during the Salmon Springs Glaciation, adranced south of Auburn at least twice. At Auburn, no significant time interval between the two advances is evident. A few miles farther south, however, a climate somewhat warmer than glacial, but still cool and moist, is recorded between the two Salmon Springs advances. After the glacier retreated, streams were again established in northwesterly courses, bringing sediments of Mount Rainier provenance again about as far north as Kent.

In late Pleistocene time, the Puget lobe of Vashon age occupied the entire Puget Sound lowland, extending about 50 miles south of Renton. Virtuclly the entire mapped area was covered with ground rooraine. The glacier probably was at least 3,000 feet thick at Renton; it rose to nearly 3,000 feet above sea level. on Tiger Mountain east of Renton and to about 1,500 feet against the Cascade Mountains southeast of Blc $\mathrm{ck}$ Diamond. North-trending valleys were formed or deepened by scour during the glaciation, but most westtrending valleys were filled with drift.

As the Vashon glacier retreated across the mapped area about 14,000 years ago, a large ice-marginal river flowed along its east boundary, then flowed westward across the drift plain to Duwamish Valley. The Duwamish and similar valleys in the lowland then contained proglacial lakes, because the glacier still blocked 
drainage to the Strait of Juan de Fuca. One lake in Duwamish Valley stood more than 250 feet above present sea level when the ice-marginal river built a large delta into it at Auburn.

By 13,500 years ago, the glacier had retreated northward far enough to permit marine water to enter Puget Sound and Duwamish Valley. A short time after the sea invaded Duwamish Valley, alluvium of the Cedar River blocked the valley at Renton, and Lake Washington was formed north of the dam. Duwamish Valley began to fill slowly with sediment brought in by the Cedar and Green Rivers, but part of it remained an arm of Puget Sound until after 5,000 years ago. About 6,600 years ago, volcanic ash was spread over the Puget Sound lowland, becoming interbedded with postglacial lacustrine and alluvial sediments over the entire area. During these times, the land stood several tens of feet higher, relative to the sea, than it does now, and it remained higher until some time after 5,000 years ago.

About 5,000 years ago, a large volcanic mudflow came down the White River valley from Mount Rainier. As it spread out in a digitate lobe on the drift plain, it partly filled the premudflow course of the White River, which was across the plain into the South Prairie Creek and Puyallup River valleys. The White River then became established in a consequent course down the axis of the mudflow lobe, emptying into Duwamish Valley at Auburn. The river cut into the mudflow and the underlying drift and carried the material derived from these deposits into Duwamish Valley. Heavily loaded, it built a broad fan in the valley, aggrading the valley to above sea level. Distributaries flowed alternately south and north along Duwamish Valley, the southern distributary extending the fan to the Puget Sound at Tacoma and the northern one extending it to the sound at Seattle. The river continued to flow alternately north and south until 1906 , when it shifted to the southern route during a flood. Since that time, the river has been artificially restricted to the southern channel.

\section{ECONOMIC GEOLOGY}

This description of economic geology treats engineering implications as well as rock and mineral resources. Application of geology to land use is even now an important aspect of the economic geology of the mapped area, and it will become more important as urbanization spreads southeast from Seattle. Natural resources being exploited are principally sand and gravel and construction stone. Mining of coal and clay formerly was important within the mapped area, but by 1961, coal mining had ceased and clay mining had dwindled to minor operations. Production of silica sand, however, was still maintained after 1961. Possibility of economic oil and gas resources in the Puget Group continued to attract attention, although no producing wells had been drilled. Peat and topsoil production was sporadic; only one operator was reported in production in 1960 by Thorsen (1961).

\section{ENGINEERING GEOLOGY}

\section{GEOLOGIC GONDITIONS THAT INFLUENGE LAND USE}

Land use in glaciated areas such as the Puget Sound lowland is especially influenced by the character of underlying materials. To make the advantageous use of the land, availability of both generalized geoloric information and site data is desirable. Geologic maps, resulting from this study (Mullineaux, 1965a, b, c) and table 6 , which briefly summarizes principal engineering properties of map units, are intended to provide some generalized geologic data. Engineering properties of some widespread ground conditions have also been provided by McLerran and Krashevski (1954) in an engineering soils manual designed to be used with the soils map of King County (Poulson and others, 1952). None of the generalized data, however, should be considered a substitute for site studies for specific projects. Geologic formations in glaciated areas are characterized by a wide range of physical propertios. Generalized data can provide an idea of the range of properties or of an average, but local conditions can vary crucially from the average.

Besides providing a qualitative comparison of properties of various units, table 6 is intended to provide some warning of special geologic conditions that conld significantly affect engineering projects. Some of thase conditions, and sources of further information regarding them, are treated in the following paragraphs.

\section{OVERCONSOLIDATION OF EINE-GRAINED SEDIMENTS}

A great difference in physical properties exists among the fine-grained deposits simply called silt, clay, and peat in this report. These differences, resulting chiefly from the compression of some deposits by thick glacier ice, are widely recognized by local geologists and engineers but should be emphasized nevertheless. For that reason, table 6 separates fine-grained sediments above the Vashon Drift from other such sediments in and below it. Postglacial silt, clay, snd peat deposits are, in general, normally consolidated in a soils engineering sense. Typically they are loose $\varepsilon$.nd soft, have high water contents, and have low bearing and shear strengths. Heavily overconsolidated (or $\mathrm{r}^{\text {re}} \mathrm{e}$ consolidated) pre-Vashon silt, clay, and peat deposits, 
Includes wide variety of natural and manmade inorganic and organic debris. Highly variable, dependent on content
and method of emplacement.
Highly variable, dependent or content and method of emplacement. Alluvium of major rivers (Qac) (Qag) Material varies widely in size and charac-
teristics along various rivers. See text.

Infiltration slow to fast, dependent on grain size. Runoff generally poor because of low
to flooding.
Water table usually near surface. Permeability greater horizontally than vertically because of interbedded layers of fine and coarse material. Deposits of mass-wasting processes Includes intimately mixed material and
discrete blocks from other mapped units. Movement as blocks and flows common. nfiltration slow. Runoff locally good but n many places poor because tepressions. Springs common.

\section{Lacustrine peat and muck (QIp) (QIm) _. Consists mostly of flne-grained, highly Runoff poor, unit occupies closed depres- compressible material with low shear strength. Locally thick. Some bogs con- tain abundant interlocked fibrous woody material especially in upper part; \\ Lacustrine silt and clay (Q/C) .......... Mostly mixtures of bedded silt, sand, and clay. Overlain in places by thin peat because unit has low surface slope.
deposits. \\ Osceola Mudflow (Qom). \\ Unsorted mixture of stones, sand, silt and clay. Boulders common.
dant montmorillonite. \\ Infiltration very slow. Runoff poor be- cause of flattish surface. Generally \\ Ice-contact stratified drift of small melt-
water streams (Qsr, Qiv, Qis; Qit \\ Sand deposits, mostly gravelly except for water streams (Qsr, Qiv silty fine silty fine sand (Qis). Collapsed strata
common. Boulders and blocks of till scattered. \\ nfiltration generally moderate to fast on natural surfaces; fast on stripped sur- erate.}

Proglacial stratified drift of large melt- W
water rivers (Opd,

ell-sorted (uniform) loose gravel and sand. Deposits of large rivers in various
topographic positions. Locally thick.

Irregularly shaped, collapsed deposits of sand and gravel. Contain scattere boulders and blocks of till.

Ice-contact stratified drift of large melt- I
water rivers (Oik in Black Diamond water rivers (Qik in Black Diam

Infiltration generally moderate to fast on natural surfaces; fast on stripped surinfiltration and low surface slope.

Infiltration moderate to fast on natural ..... do surfaces, fast on stripped surfaces. Runoff generally poor because of infiltration.
Water table often near surface. Permeability generally low.

Water table usually at or near surface. Permeability variable.

Water table generally near surface. Permeability low, probably greater horizontally than vertically.

ater table may be very near surface. Permeability low.

Water table low where deposit lies on slope; high where it lies on valley floor or in drift-plain depression. Permeability generally high. Water table generally low. Springs in basal
zone common where it overlies till. Permeability generally high.

All deposits below have been overridden a 7 d compacted

Vashon Drift, ground-moraine deposits Intimately graded mixture of clay to (Qgt).

Undifferentiated pre-Vashon deposits Inte (Qu). gravel sizes. Contains local lenses of sand and gravel. Hardpan of common usage Here refers to subglacial lodgment til which is oyerlain by a few foet of les compact ablation till (see text). gravel, and till.
Infiltration very slow. Runoff good on slopes, but

Exposed only on valley walls. Runoff goo except where affected by landslides.

on water common over till. Permeability lenses.

Contains much water, locally perched. Interbedding restricts vertical permeability. Springs abundant.
Salmon Springs Drift (Qss) ............ Chiefiy sand and gravel with interbedded

Salmon Springs Drift (Qss) ............. Chiefiy sand and gravel with interbedded

Salmon Springs Drift (Qss) ............ Chiefiy sand and gravel with interbedded

Puyallup(?) Formation (Qpy)

Chiefiy volcanic sand. Contains some silt mudflow.

Intermediate drift (QId). Chiefly two fine-grained till sheets separated by interbedded sand, silt, and clay.

Orting(?) Drift (Qor)

Mostly sand and gravel, but includes silt Mostly sand and gravel, but incila
and clay beds and stony till. nfiltration generally slow to moderate. Generally exposed only on slopes where runoff is good
landslides.

Infiltration slow to moderate. Runoff generally good because formation exposed only on steep slope.

Infiltration slow because exposed on slopes, and contains numerous finegrained beds. Runoff generally good because of slope, except where affected by landslides. Infiltration slow to moderate. Runoff good
Contains much water, perched in places, and confined elsewhere. Permeability highly variable, even in sand and gravel clay matrix. Springs abundant.

Commonly contains some water. Permeability low to moderate. Interbedding restricts vertical permeabil ty.

Generally contains water, perched in places. Permeability locally high in gravel; low in till and clay. Interbedding restricts vertical permeability. Springs
abundant.

Generally contains water, perched in places. Permeability mode ate to high in gravelly and coarse sand
clay. Springs abundant.
Hammer Bluff Formation (Th)

Lower member mostly quartz sand and kaolinitic clay. Upper member mostly gravel.
Infiltration generally slow. Runoff fair. Formation generally is exposed on slopes, but sliding prod
undrained depressions.
Contains abundant water. Permeability generally low, but may bis moderate to high in clean quartz sand beds near base. 
mapped units in the Renton, Auburn, and Black Diamond quadrangles

from U.S. Army Corps of Engineers (1953)]

\begin{tabular}{|c|c|c|c|c|}
\hline Ease of excavation & Foundation stability & Slope stability & Reported or possible uses & $\begin{array}{c}\text { Principal } \\
\text { soil groups } \\
\text { (Unified Soil } \\
\text { Classificat'on) }\end{array}$ \\
\hline $\begin{array}{l}\text { Highly variable, dependent on content } \\
\text { and method of emplacement. }\end{array}$ & $\begin{array}{l}\text { Highly variable, dependent on con- } \\
\text { tent and method of emplacement. } \\
\text { May contain high proportion of } \\
\text { voids, and both rapidly compressi- } \\
\text { ble and slowly decaying, slowly } \\
\text { compressible material. }\end{array}$ & $\begin{array}{l}\text { Highly variable, dependent on con- } \\
\text { tent and method of emplacement. }\end{array}$ & & \\
\hline $\begin{array}{l}\text { Generally easy to excavate with hand } \\
\text { or power equipment. Much could be } \\
\text { dredged. }\end{array}$ & $\begin{array}{l}\text { Fair to excellent depending on grain } \\
\text { size, In Duwamish Valley, locally } \\
\text { contains compressible layers of or- } \\
\text { ganic material. }\end{array}$ & $\begin{array}{l}\text { Generally fair to poor because loose } \\
\text { and saturated to near surface. May } \\
\text { stand in steep cuts where above } \\
\text { water table. }\end{array}$ & $\begin{array}{l}\text { Fill, topsoil. Channel gravel is a } \\
\text { major source of commercial sand } \\
\text { and gravel. Alluvium in White } \\
\text { River valley and Duwamish Val- } \\
\text { ley contains porous glassy volcanic } \\
\text { rocks that may be chemically re- } \\
\text { active in high-alkali concrete. }\end{array}$ & $\begin{array}{l}\text { Includes virtu- } \\
\text { ally all. }\end{array}$ \\
\hline $\begin{array}{l}\text { Generally easy to excavate with hand } \\
\text { or power equipment. Locally con- } \\
\text { tains large stones. Commonly cohe- } \\
\text { sive. }\end{array}$ & $\begin{array}{l}\text { Mostly subject to further movement. } \\
\text { Corrective measures needed. }\end{array}$ & $\begin{array}{l}\text { Both natural and cut slopes generally } \\
\text { of limited or temporary stability. }\end{array}$ & (6) & $\begin{array}{l}\text { Includes virtu- } \\
\text { ally all ex- } \\
\text { cept GF,GW, } \\
\text { SP, SW. }\end{array}$ \\
\hline $\begin{array}{l}\text { Generally easy to excavate with hand } \\
\text { or power equipment; fibrous woody } \\
\text { material containing interwoven } \\
\text { stems much more difficult. May con- } \\
\text { tain large crisscrossed logs. }\end{array}$ & $\begin{array}{l}\text { Very poor. Low shear strength, and } \\
\text { will settle significantly under load. } \\
\text { Some shallow deposits could be re- } \\
\text { moved prior to construction. }\end{array}$ & $\begin{array}{l}\text { Not generally found on natural slopes. } \\
\text { Cutbanks variable; fibrous peat in } \\
\text { upper part of deposit may stand in } \\
\text { steep cuts, yet lower peat runs } \\
\text { freely. }\end{array}$ & Topsoil beneficiation.... & Pt, OH, OL. \\
\hline $\begin{array}{l}\text { Easy to excavate with hand or power } \\
\text { equipment. May be cohesive. }\end{array}$ & $\begin{array}{l}\text { Generally fair to poor. Contains some } \\
\text { compressible strata. }\end{array}$ & $\begin{array}{l}\text { Will stand in steep cuts where dry, but } \\
\text { much less stable where wet. Cut } \\
\text { slopes are subject to gullying and } \\
\text { landsliding }\end{array}$ & Topsoil. & $\mathrm{ML}, \mathrm{OL}, \mathrm{CL}$ \\
\hline $\begin{array}{l}\text { Difficult to excavate with hand or light } \\
\text { power equipment. Dense, tough and } \\
\text { cohesive; lacks bedding, contains } \\
\text { scattered large boulders. }\end{array}$ & $\begin{array}{l}\text { Fair to good in crust near surface. Lo- } \\
\text { cally has low shear strength below } \\
\text { water table in thick deposits. (See } \\
\text { Crandell, 1963, p. A74-A75.) }\end{array}$ & $\begin{array}{l}\text { Stands in steep natural and cut slopes } \\
\text { where moderately dry. Small } \\
\text { amounts of water can decrease sta- } \\
\text { bility markedly. }\end{array}$ & Fill__. & GC, GM. \\
\hline $\begin{array}{l}\text { Generally easy to excavate with hand } \\
\text { or power equipment. Contains few } \\
\text { boulders. }\end{array}$ & Good to excellent & $\begin{array}{l}\text { Generally unstable in steep cuts be- } \\
\text { cause of lack of binder, but may } \\
\text { stand for short periods. Failures } \\
\text { generally extend only a few feet be- } \\
\text { low surface. Cut slopes in sand sub- } \\
\text { ject to gullying. }\end{array}$ & ....................... & SP, SW, SM. \\
\hline $\begin{array}{l}\text { Generally easy to excavate with hand } \\
\text { or power equipment. Noncohesive. }\end{array}$ & ....-do & $\begin{array}{l}\text { Generally unstable in steep cuts be- } \\
\text { cause of lack of binder, but may } \\
\text { stand for short periods. Failures gen- } \\
\text { erally extend only a few feet below } \\
\text { surface. }\end{array}$ & $\begin{array}{l}\text { Fill. A major source of commercial } \\
\text { sand and gravel. }\end{array}$ & GP, SP. \\
\hline $\begin{array}{l}\text { Generally easy to excavate with hand } \\
\text { or power equipment. Contains } \\
\text { scattered boulders and blocks of till. }\end{array}$ & $\ldots d o_{\ldots}$ & do do. & Fill. Commercial sand and gravel. & GP, SP. \\
\hline
\end{tabular}

by one or more glaciers at least 1,500 feet thick

Very difficult to excavate with hand or Excellent. No settlement expectable... light power equipment. Stony, dense, tough, and coherent. Gener ally lacks bedding or extensive fracturing. Contains scattered large

Highly variable. Except till, generally can be excavated with hand or light power equipment. Till difficult to pxcavate.

Most sand and gravel strata can be excavated with hand or light powe equipment, but locally they contain firm binder. Till similar to Vashon till, very difficult to excavate.

Generally can be excavated with hand or light power equipment except mudflow and compact peat beds, both of which are tough, coherent, and difficult to excavate.

Except till, generally can be excavated with hand or light power equipment. Till tough and cohesive, but cult to excavate than stony till.

Sand and gravel generally can be excavated with hand or light power to excavate.

Fair to poor. Crops out on slopes where water is abundant. Virtually no consolidation expectable, but to slope, moisture, and distribution of silt and clay.

Good to poor. Crops out on slopes where water is abundant. Virtually no consolidation expectable, but subject to landslid slope, moisture, and distribution of silt and clay.

Stands in steep natural and artificial Fill GC, GM. cuts for long periods. Stability lessened locally by lenses of stratified material.

Locally stands in steep natural and artificial cuts. Landslides common.

Locally stands in relatively steep nat- Fill, common and select. ural or cut slopes for long periods. Stony till forms ledges resistant to stream erosion and mass wasting. Locally subject to landsliding.

Locally stands in steep artificial and natural slopes. Mudfiow and peat
deposits form resistant ledges.

Fill. Sand contains some glassy volcanic rocks that may be chemically reactive in high-alkal

air to poor. Crops out on slopes wo consolidation expectable, but no consolidation expectable, but slope, moisture, and distribution of slope, moisture,
silt and clay.

Good to poor. Crops out on slopes where water is abundant Virtually no consolidation expectable but subject to landsliding dependent on slope, moisture, and distribution of silt and clay. Landsliding especially widespread where underlain by Hammer Bluff Formation.

Clean quartz sand beds can be exca- Poor. Crops out on slopes; springs and vated by hand or light power landslides abound in nearly all areas quipment clay and clayey sand more difficult.

ocally stands in steep natural and cut Fill, common clay products........ slopes. Landslides common.

Locally stands in steep natural and cut Fill, common and select slopes for long periods. Stony till forms ledges resistant to erosion. Landslides common.

Can stand in steep natural and cut Semirefractory and common clay slopes for short dry periods, but products. Silica sand. generally is wet. Landslides very 
TABLE 6.-Generalized description of engineering properties of princiral mapped

[From Mullineaux (1965a, b, c) Soil groups

\begin{tabular}{|c|c|c|}
\hline \multirow[t]{2}{*}{$\begin{array}{l}\text { Units (Symbols used are from } \\
\text { Mullineaux, } 1965 \mathrm{a}, \mathrm{b}, \mathrm{c} \text { ) }\end{array}$} & Special features & Ground water \\
\hline & \multicolumn{2}{|r|}{ All formations } \\
\hline Intrusive rocks $(\mathrm{Ti}) \ldots \ldots$ & $\begin{array}{l}\text { Igneous rock cooled from melt. Numerous } \\
\text { crosscutting fractures. Contains clay } \\
\text { zones and veins. } \\
\text { Partly cemented. Contains zeolite and } \\
\text { glassy volcanic rocks. Fragments com- } \\
\text { monly altered, many are soft. }\end{array}$ & $\begin{array}{l}\text { Infiltration slow. Runoff excellent ...... Ground water occurs in fractures: Perme- } \\
\text { ability very low except along fractures }\end{array}$ \\
\hline $\begin{array}{l}\text { Puget Group undifferentiated, Renton } \\
\text { Formation, and middle member of } \\
\text { Tukwila Formation (Tp, Tr, Tta). }\end{array}$ & $\begin{array}{l}\text { Partly cemented quartzose feldspathic } \\
\text { sandstone. Cement generally is calcite. } \\
\text { Locally friable. }\end{array}$ & ndo do \\
\hline $\begin{array}{l}\text { Tukwila Formation-upper and lower } \\
\text { members }(T t u, T t) \text {. }\end{array}$ & $\begin{array}{l}\text { Partly cemented, locally weathered sand- } \\
\text { stone, conglomerate, and mudstone } \\
\text { composed of fragments of volcanic rock. } \\
\text { Contains some bouldery beds. }\end{array}$ & do do \\
\hline
\end{tabular}

however, are relatively compact and hard, have low water contents, and have high bearing and shear strengths. These are fairly "strong" sediments, but they present special problems of their own, among which are vertical and horizontal rebound on unloading. Horizontal rebound apparently is especially critical, and it has been credited with causing damaging landslides in Seattle (Wilson and Johnson, 1964).

\section{GROUND WATER}

Ground water, which can be expected to present problems for both light and heavy construction, is abundant, and the water table in the drift plain typically is high above the level of nearby valley floors. Ground water occurs at many different stratigraphic positions, some perched within the typically interbedded impervious and pervious layers of Pleistocene sediments. Moreover, artesian conditions are not uncommon. On the Duwamish Valley floor north of Kent, a drilled well that intersected Pleistocene sediments under the alluvium produced more than 1,700 gallons per minute under pressure equivalent to a water surface 90 feet above the valley floor (Luzier, 1969). These conditions obviously can be of major concern for developments that require cutting along valley walls or tunneling through the drift plain. Valley-floor sediments also include interbedded deposits that carry highly diverse amounts of water. One hazard involved in trenching or other excavation in the alluvium, for example, is the possibility of intersecting linear meandering deposits of channel gravel that can prodice very large flows of water.

Extensive information on ground-water conditions in the mapped area, much of which is pertinent to engineering projects, is included in the ground-water report by Luzier (1969).
HETEROGENEITY OF GLACIAL TILL

Knowledge of glacial till is important to engineering practice because the till is so widespread and so variable in physical properties and thickness. As mapped, glacial till includes all unsorted and unstratified material deposited by the glacier. It may be compact or loose and may be composed largely of silt and clay or largely of gravel and sand. The concretelike lodgment member of the Vashon till (commonly called hardpan) is widely recognized as till; but the looser ablation member is not so often recognized, because it is so different from the "typical" lodgment till. Nor are the abrupt changes that characterize the till, or the great variety of grain sizes that compose it, always recognized. The objective of this discussion is to emphasize that (1) till, especially the Vashon, consists of two members that are very different ir physical properties, chiefly compactness and coherence; (2) either of these members can, at any one point, compose most or all of the till mapped; (3) till sheets as a whole (and the lodgment and ablation members individually) typically vary widely in thickness from place to place; and (4) even compact lodgment till contains weak zones. The importance of any one of these factors as compared with another factor probably depends mostly on the type of project. Small construction jobs in Vashon till, for example, might be much more affected by the diversity in compactness than large jobs would be.

The Vashon till, which covers about half tr a mapped area, illustrates the great heterogeneity of till. Where mapped, it usually consists of thin ablation over lodgment till, but at any one place might consist mostly of either member. Important variable features of the lodgment member are thickness, amount of silt and clay "binder," and presence or absence of weak zones. 
units in the Renton, Auburn, and Black Diamond quadrangles-Continued

from U.S. Army Corps of Engineers (1953)]

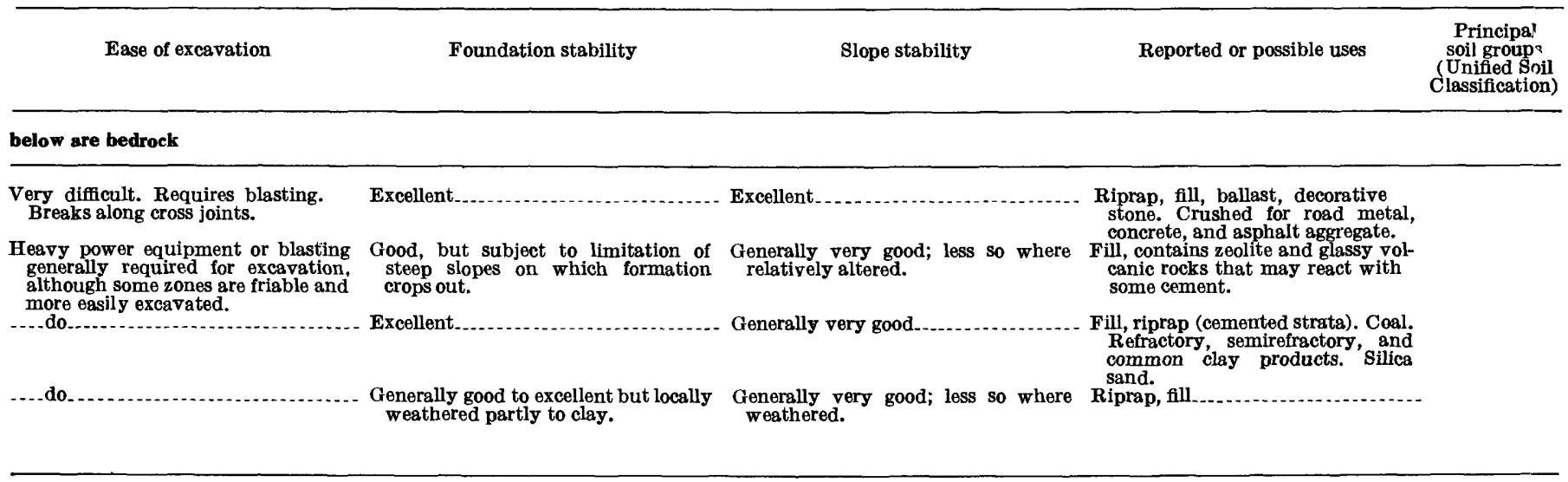

Thickness' commonly ranges from a few inches to about 20 feet, though lodgment till as thick as 70 feet is exposed. In places, as in Renton north of the Cedar River, it is nearly all silty and gravelly sand; elsewhere it contains as much as 50 percent silt and clay. With low silt and clay content, it is friable enough that fragments can be crushed in the hand, yet even that material might require ripping before it could be removed effectively with large earthmoving equipment. With higher silt and clay content (for example, 20-40 percent), till is typically coherent, tough, hard and resistant to penetration, and nearly uniformly resistant to breaking. With still higher silt and clay content, the till tends to remain coherent but be less hard and more likely to contain fractures along which blocks can be separated from the main mass. In many places, lodgment till contains lenses of gravel or sand, but the location of such lenses cannot be predicted. The lenses are important, however; they can give up large amounts of water for short periods, and they are weaker zones that make the till easier to excavate but that reduce its ability to stand in opencuts.

Vashon ablation till is not as compact or as coherent as lodgment till, because it has not been heavily loaded by ice. Generally it is less than 5 feet thick, but it locally has been seen as thick as about 10 feet. It is mostly a poorly sorted clayey, gravelly sand. Locally it grades into better sorted gravel and sand that by increase in thickness and continuity grade into the mapped deposits of recessional outwash. Ablation till generally presents only minor excavation problems, but it does contain widely distributed large boulders. It is not nearly as stable in opencuts as lodgment till, however, and it is more permeable.

Differences between lodgment and ablation members in the pre-Vashon tills are of less importance, because all have been overridden by thick ice. Orting(?) and Salmon Springs tills are generally stony and are similar to Vashon lodgment till. Till in the intermediste drift typically contains more silt and clay and is softer than any of the other tills, and it contains numercis joints along which the unit breaks (fig. 15).

\section{LANDSLIDES}

Existing and potential landslides in this area s,re worthy of considerable attention. They are a problem now and will affect an ever increasing number of people as urban development spreads across the arja. Many hazardous landslide areas are shown on geologic maps (Mullineaux, 1965a, b, c), on which they sre mapped as part of the colluvium. But it is to be emphasized that not nearly all landslides are mapped, and areas of potential landslides are not differentiated as a map unit. Urban development may well proceed faster than zoning that would provide warning of potential landslide areas. Thus, companies and individuals concerned with development probably shovld recognize for themselves the problem that landslides embody.

Simply recognizing the areas of potential sliding is an important step. Once a possible landslide danger is recognized, each area of interest can be treated as a site problem, and whatever examinations are necessø.ry can be made. This recognition of areas where slides either exist or might occur can be gained to some extent by examination of available topographic and giologic maps. Examination on the ground, however, is more desirable.

Available maps can be used to a certain extent to locate areas of existing or potential slides, but tray probably are more useful toward distinguishing areas where site evaluation is needed. The topographic maps show factors such as location, height, and steepness of 
slopes. As has been described, landslides are concentrated and should be expected along any steep slope, and especially along the walls of postglacial stream valleys. The topographic maps also show positions of rivers and creeks - in some places it is possible to estimate the points at which a stream will undercut adjacent valley walls. Geologic maps not only show the location of many areas in which landslides are the dominant surficial material, but also show the types of materials that make up the various slopes. Map explanations, to a certain extent, and table 6 indicate relative susceptibility to sliding; landslides are much more abundant and probable on slopes in the Hammer Bluff Formation, for example, than on comparable slopes in Vashon Drift.

Field examination is desirable because sites of existing and potential slides in many places are more clearly evident by such examination than on maps, and because local conditions not evident from maps can strongly influence susceptibility to sliding. Landslides probably are most readily recognized by surface expressions, though recognition can be furthered through examination of internal features and stratigraphic relations. Descriptions of features characteristic of landslide types that are common in the mapped area (p. 53) are contained in many studies, such as those of Sharpe (1938) and Eckel (1958) and in the references contained in those studies. Surface features that particularly help to identify landslides locally are hummocky surfaces, tilted blocks, subparallel ridges that run across rather than down the slope, ponds and other disruptions of drainage, tilted trees, lobate surfaces that are convex downslope, cracks in the ground surface, and steep and often curved scarps that are bare or nearly bare of vegetation. Internal features that are helpful are randomly oriented blocks and small chips of stratified sediments in a nonstratified matrix, crude layering or slickensided surfaces that parallel the slope, and a matrix which is largely nonsorted and nonstratified like till but which is soft and sticky. Downslope displacement of identifiable stratigraphic units is an excellent criterion of past landsliding, but the recognition of this displacement usually requires detailed study.

Not only the natural conditions conducive to landsliding, but also the effects of artificial changes should be considered. Undercutting, loading, and addition of water probably are the most important artificial changes that cause sliding in the mapped area. Undercutting of slopes by excavation and loading (usually by artificial fill) are typical of urban or suburban developments. Artificial concentrations of natural rain- fall and increases in the amount of water arplied to the ground, which commonly result from paring and lawn watering that accompany residential development, can cause sliding on slopes that have besn stable for many years.

\section{GONSTRUGTION MATERIALS}

SAND AND GRAVEL

Sand and gravel suitable for construction material is abundant in the area. For some purposes it can be used as taken from natural deposits, but probably most of it is processed. It is used locally for a wide variety of purposes, especially railroad ballast, common and select fill, roadbase and surface courses, and concrete and mortar aggregate.

Some physical properties that make a s?nd and gravel deposit desirable for construction material are abundance of gravel, uniformity in grain size snd quality, and ease of excavation. The component materials should also be durable, clean, and not chemicrlly reactive in concrete. These requirements locally are best fulfilled by Vashon recessional gravels, especially the outwash deposits of the large ice-marginal river in the Black Diamond and Auburn quadrangles. T ose outwash deposits generally contain abundant gravel but few boulders too large for crushers, they are friable, and they occur in large accessible bodies. Tra gravel consists largely of hard volcanic rocks that are not chemically reactive in concrete, and it contains only small amounts of clay, iron oxide, and other deleterious materials. Smaller Vashon recessional outwash deposits elsewhere in the quadrangles and channel deposits of the Cedar and Green Rivers are generally similar to the ice-marginal river gravels, except that they are usually finer grained and less voluminous. Alluvium of the White River, however, contains abundant glassy porous volcanic rocks that might be chemically reactive. Although sand and gravel is also abundant in Vashon advance outwash and in pre-Vashon formations, these sediments usually are accessible only where exposed in valley walls or on other stesp slopes. Pre-Vashon gravels, moreover, typically are at least partly coated with clay and iron oxide, and some stones are partly weathered. The only pre-Vashon sand and gravel deposits that typically are not iron stained contain abundant glassy volcanic rock fragment: like the material in modern alluvium along the White River.

The outwash of the large ice-marginal stream has been most widely exploited, and probably the most utilized part of the outwash deposits has been the delta at Auburn. The Auburn delta, because it formed as a fill in the Duwamish trough at the end of the long 
valley train, is thick, coarse grained, and well sorted. It consists of loose uniform pebble-and-cobble gravel and sand; it is more than 150 feet thick above the level of the modern flood plain; and it crops out for more than a mile and a half along the readily accessible Duwamish Valley between the Green and White Rivers. In the past, this deposit has been mined by a railroad company, by at least two commercial sand and gravel companies, by public agencies, and by numerous individuals. A large kame-terrace deposit laid down by the same ice-marginal river lies south of the White River across from the Auburn delta, but the terrace deposits are much less uniform overall and, in places, much more sandy than the delta. The kame terrace appears to have been exploited only intermittently and on a small scale.

East and northeast of the Auburn delta, valley-train, outwash-plain, and kame-field gravels cover 15-20 square miles in the Black Diamond quadrangle and generally are from 10 feet to several tens of feet thick. Although these gravels are similar to those in the delta, they are less uniform in grain size and are thinner. Generally they have been excavated in pits, and this type of excavation is more complicated than that in the face of the Auburn delta. Many pits, however, have been established in the outwash, the largest of which is a county-owned pit in sec. 26, T. 22 N., R. 5 E. Most of this gravel is used locally, largely for road construction.

Smaller outwash deposits are widely distributed over the Renton quadrangle, but their small size, internal variation, and abundance of sand make them less desirable than the ice-marginal outwash gravels. Fairly extensive terrace and delta deposits in Renton on the north side of the Cedar River in secs. 16 and 17 are the most extensively worked of these deposits. The sediments in that locality are reasonably uniform but contain much more sand than the Auburn delta.

Of the modern river gravels, only the Cedar River deposits were being used as a major source of sand and gravel in 1961. Cedar River channel deposits at Renton have been mined for sand and gravel for many years by a commercial firm, and the alluvium has also been used as a source of sand for special purposes by other producers. Mining from the river channel is aided by the continual replenishment of the deposits by the river. Some older Cedar River bars also are being mined upstream, near the edge of the Renton quadrangle. Green River channel deposits east of Auburn appear to be a comparably good source of gravel but probably are not now economically competitive with gravel of the Auburn delta. The wide gravel flood plain of the White River could also be a source of abundant gravel for uses in which the porous glassy volcanic rocks would not be detrimental.

\section{STONE}

The Seattle metropolitan area generates a large demand for many types of stone, but only a limited source of broken stone is known in the mapped arja, and no economic source of dimension stone or otr ar building stone (Moen, 1967) has been discovered. Broken stone is used in large quantities as riprap for bank protection along rivers, for bulkhead protection along the Puget Sound, for utilitarian retaining walls, and for protective blankets for slopes. It is also used widely for decorative landscaping where slope prot:ction is not a problem. Smaller pieces of the stone are crushed and used for ballast, fill, and concrete aggregate, and poor-quality stone and quarry strippings are used as fill.

Broken stone should be hard, tough, and durable; the rock body should be accessible, large enough to develop economically, and capable of being easily brolen into blocks of a desirable size. Its value is consideralily greater if it is also decorative. Very little rock in the area meets these standards. In general, only the int: $u-$ sive rocks are suitable; sedimentary rocks of the Tukwila, Renton, and Lincoln Creek(?) Formations g?nerally are not used because they are too poorly or too irregularly indurated. In 1961, only the large intrusive body west of Renton was being quarried. Earlier, one small quarry was operated in Tukwila volcanic brecria and flow rocks in northwest Renton and another ras operated in a sill at Tukwila, but in 1961 both were inactive and nearly surrounded by residences. An intrusive rock body south of Renton along Duwamish Valley is small but otherwise appears to be suitable for quarrying. No other suitable rock bodies are known in the Auburn and Black Diamond quadrangles, althorgh good sources exist east of the Black Diamond quadrangle.

The active quarry is in a body of hard, dense gre?nish-gray andesite about 2 miles west of Renton. Because of cross jointing, the rock breaks readily into blocks, many of which are large enough for riprap and also for decorative landscaping stone. The quality of the rock is generally regarded as good, but it varies considerably within the body, depending on amount of alteration and distribution of veins.

\section{SILICA SAND}

Silica sand is mined from the Hammer Bluff Formation and the Puget Group. At Hammer Bluff, in sec. 28 , T. 21 N., R. 6 E., sand was being mined in 1961 from the quartzose lower member of the Hammer Bluff 
and from the underlying weathered Puget arkose. It was trucked to Seattle and was used chiefly in the manufacture of colored bottles. Both the Hammer Bluff Formation and the Puget arkosic rocks have been reported as being used for molding sand (Valentine, 1949), but no sand was being produced in the mapped area in 1961.

Hammer Bluff quartzose sands have proved suitable as a source for glass sand, chiefly because of the alteration of feldspar to clay. Some of the feldspar was weathered to clay while the sand grains were still part of the Puget Group arkoses. Weathering after the grains were redeposited in beds of the Hammer Bluff Formation further reduced the feldspar content, so that now an adequate concentration of quartz can be obtained by washing out the clay. In some parts of the lower member, however, sand-size aggregates of siderite and clay, or other concentrations of iron oxide, exceed the limit of iron currently permissible for use of the sand for glass. No sand in the upper member of the formation is likely to prove satisfactory as a source, because it contains very little quartz and much iron.

Parts of the Puget arkose at Hammer Bluff are also suitable for glass sand, because alteration and leaching have reduced the amount of feldspar, iron, and cement, thus producing a workable sand from which the clay can be washed satisfactorily. The topmost part of the weathered Puget Group at Hammer Bluff is so low in iron that it has been used to "sweeten" other lessweathered arkose that contains too much iron for glass sand, thus increasing the usable tonnage. Distribution of iron oxide from leaching and redeposition strongly affects the amount of usable material, because the ironbearing detrital minerals nearly equals currently allowable limits. Siderite and most other iron-bearing grains are susceptible to laboratory removal by chemical, mechanical, and magnetic methods, but apparently it is not now economic to remove them on a large scale.

\section{OIL AND GAS}

Gas was discovered in the Lawson test hole drilled in 1911 in Puget Group rocks near Black Diamond in the $\mathrm{S} 1 / 2 \mathrm{E} 1 / 4$ sec. 27 , T. 21 N., R. 6 E., during a search for coal (Livingston, 1958). Oil shows were reported in holes drilled nearby in the late 1920's and early 1930's, but the first confirmed report of an oil show was in 1936 in the Bobb 1 well drilled in the NE $1 / 4$ sec. 34 (Livington, 1958). Since that time, the Puget Group has been investigated fairly extensively by several oil companies, but only a few holes have been drilled. Since the drilling of the Lawson test hole, 13 holes have been drilled on the Black Diamond anticline south of the Green River, 11 of which are within the mapped area (Livingston, 1958).

Exploration has been spurred by both the evidence of oil and gas and by conditions regarded as favorable for their occurrence. In virtually all parts of the stratigraphic section of the Puget Group near Blfck Diamond, for example, oil shows have been reported. Porosity and permeability of the rocks, though variable, locally are high. Marine rocks of the same age as part of the sequence at Black Diamond are known both north (Warren and others, 1945; Vine, 1969) and southwest of the area (Weaver, 1937; Snavely and others, 1958). Within the Black Diamond ares, brackish-water fossils have long been known, and salt water has been reported from test holes. The Puget Group is also folded into well-known anticlines and synclines and is cut by numerous though mostly small faults that could have formed structural traps.

The Black Diamond anticline has attracted most of the attention so far, chiefly because previous drilling in it has shown some gas and oil. To and including 1961 , no drilling had been done in similar, well-known anticlines in the Puget Group to the northesst. The deepest hole on the Black Diamond anticline penetrated about 6,000 feet of the Puget Group, with oil shows virtually all the way to the bottom. No closure of this north-plunging anticline is known, although an interpretation of it by Anderson (1959) show: several faults, the importance of which he notes as po:sible oil traps. A sketch map by Anderson (1959) also shows other north-trending anticlines west of the Black Diamond anticline, where the bedrock is covered by Quaternary deposits; he, however, did not present evidence for the existence of the anticlines. A lack of surface evidence of structure features restricts effort to systematically explore for oil in that part of the area.

At Renton, Puget Group arkose is also locally porous and permeable, but the section of arkosic rocks is much thinner, and a thick section of andesitic sedimentary rocks appears to occupy the stratigraphic interval in which oil shows have been found ne?r Black Diamond. However, possible source rocks of marine origin crop out nearby below the Puget Group (Waldron, 1962).

\section{CLAY}

Clay suitable for a wide range of products is available in the mapped area, both in Tertiary and Quaternary formations. Some clay has been produced from the Renton Formation near Renton, but most has come from the Puget Group and Hammer Bluff Formation near Black Diamond. Quaternary glacial clays are abundant but little used, principally because they are 
neither as abundant nor as accessible as are similar clays in the city of Seattle. The Tertiary clay has been used for refractory ware (for this ware it is generally mixed with other clay), semirefractory and nonrefractory pottery, terra cotta, sewer pipe, paving brick, hollow brick, common brick, face brick, and common draintile. Between 1950 and 1960, however, Tertiary clays were mined only intermittently, and as far as is known, no glacial clay was taken out. Earlier in the century, a commercial plant at Renton used Hammer Bluff clay and Puget shale from the Renton and Black Diamond districts; the Hammer Bluff clay was also shipped to Seattle and Auburn for processing (Glover, 1941).

Only one deposit in the mapped area, the flint claystone in the Puget Group at Kummer south of Black Diamond, meets the specifications for a refractory clay (Glover, 1941). Its refractory properties are suitable because it consists largely of the high-alumina clay kaolinite and of aluminum oxides or hydroxides; according to Nichols (1946), the Kummer claystone is composed chiefly of kaolinite and gibbsite and probably alumina gel. Cone fusion (or pyrometric cone equivalent) values of the claystone reported by Glover (1941) are as high as 32. The claystone has been mined on both sides of the Green River in the east limb of the Black Diamond anticline. The claystone has been reported to also be on the west limb of the Black Diamond anticline, but this area is largely covered by Quaternary deposits. As late as 1959, the claystone was being mined underground in the east limb of the Black Diamond anticline on the south side of the river.

Semirefractory and nonrefractory clays occur in arkosic strata of the Puget Group and in the Hammer Bluff Formation. A large amount of Puget shale has been taken from the south side of the Cedar River valley in Renton, but little was being mined in 1961 . Similarly, in several places near Black Diamond, Puget shale and Hammer Bluff clay have been repeatedly mined for shipment to Renton, Auburn, and Seattle, but little was being mined in 1961. Clay minerals in the shale from the Puget are mostly kaolinite, but they also include mica or illite, and chlorite; the shale also contains much feldspar. Cone fusion values for various samples of Puget shales from the mapped area reported by Glover (1941) ranged from about 6 to 13. Shale of comparable quality probably is widespread in the Puget Group.

Cone fusion values for Hammer Bluff sediments reported by Glover ranged from about 15 to 26 . One light-gray clay collected from the lower member of the Hammer Bluff during this investigation, identified by $\mathrm{X}$-ray methods as composed almost entirely of kaolin- ite, fused at cone fusion value 28. A sample of brown clay from the upper member, composed of about equal amounts of kaolinite and montmorillonite, fused at about cone fusion value 15 .

Glacial clay that should be suitable for common and face brick occurs in the intermediate drift and in the undifferentiated drift along the Cedar River valloy. These clays consist chiefly of mixtures of chlorite, mica or illite, and montmorillonite, plus quartz and feldspar; they are similar to the glacial clay in Seattle that has been used for common brick for many years. Glover (1941) reported cone fusion values of $2-5$ for most glacial clays from Seattle, and cone fusion values for five Pleistocene clays sampled during this investigation ranged from about 1 to 8 .

\section{COAL}

Coal is abundant in the bedrock, both in the Renton Formation and in the undifferentiated Puget Grcrip near Black Diamond; it was mined intermittently for about 100 years at Renton and for about 75 years at Black Diamond. Most coal of the Black Diamond district is bituminous, and most in the Renton district is subbituminous (Beikman and others, 1961). The Puget Group in both districts is folded and cut by faults that make tracing and mining of the coal beds difficult. $\mathrm{P} \times \mathrm{O}$ duction has declined irregularly in this area since about the end of World.War I; in 1961 no coal was produced from the mapped area.

In the Renton district, the best coal occurs near the middle of the formation in the Renton No. 1, Renton No. 2, and Renton No. 3 beds, but other coal beds naar the base of the formation have also been mined. Carbonaceous shale occurs higher than the Renton Nc. 1 bed, but no coal is known. At Black Diamond, in the western part of the Green River district, coal occurs throughout most of the stratigraphic sequence. The principal coal bed is the McKay (Beikman and others, 1961), near the base of the sequence exposed within the quadrangle. Stratigraphically higher coal is repor ${ }^{+}$ed to be of lower rank. These coal fields were studied extensively during mining operations and were described by Willis (1886, 1898a), Evans (1912), and Warren, Norbisrath, Grivetti, and Brown (1945); the reserves of coal that remain have been described by Beikman, Gower, and Dana (1961). No new coal beds were discovered during the present investigation.

\section{PEAT AND TOPSOIL}

Peat and topsoil are mined locally for soil beneficiation, chiefly for commercial and private landscaping. At various places, moss peat, shallow bog deposits of 
fibrous and sedimentary peat mixed with inorganic silt and clay, and overbank silt and fine sand are being exploited and either used locally or trucked to the Seattle metropolitan area. According to Thorsen (1961), one operator was mining peat within the mapped area in 1960, at the south end of Lake Meridian. Overbank deposits have been mined sporadically from the upper 20 feet of the Duwamish Valley flood plain west of Kent for many years.

Peat and mixtures of silt, clay, and peat are widespread in bogs on the upland. These bogs could become important local sources of soil conditioners, and some probably will become nursery sites as suburban development spreads southeast from Renton. Because these deposits contain little pure moss peat, they probably will be used only locally. Peat also occurs in a few deposits on the floor of Duwamish Valley; they are concentrated along the margins of the White River fan near Auburn and the Cedar River fan near Renton. Peaty overbank silt and fine sand, similar to that being mined west of Kent, is abundant at and near the surface on most of the Duwamish Valley floor between Kent and the north boundary of the Renton quadrangle.

\section{REFERENCES CITED}

Anderson, J. Q., 1959, Puget Sound area [Washington] has several prospective oil and gas basins: World Oil, v. 149, no. 1, p. 111-113.

Armstrong, J. E., and Brown, W. L., 1954, Late Wisconsin marine drift and associated sediments of the Lower Fraser Valley, British Columbia, Canada: Geol. Soc. America Bull., v. 65, no. 4, p. 349-363.

Armstrong, J. E., Crandell, D. R., Easterbrook, D. J., and Noble, J. B., 1965, Late Pleistocene stratigraphy and chronology in southwestern British Columbia and northwestern Washington: Geol. Soc. America Bull., v. 76, no. 3, p. 321-330.

Beikman, H. M., Gower, H. D., and Dana, T. A. M., 1961, Coal reserves of Washington: Washington Div. Mines and Geology Bull. 47, 115 p.

Beikman, H. M., Rau, W. W., and Wagner, H. C., 1967, The Lincoln Creek Formation, Grays Harbor basin, southwestern Washington: U.S. Geol. Survey Bull. 1244-I, 14 p.

Bond, J. G., 1959, Sedimentary analysis of [Eocene] Kummer formation within the Green River Canyon, King County, Washington: Washington Univ., unpub. M.S. thesis.

Bressler, C. T., 1957, The petrology of the Roslyn arkose-a study in tectonic control of sedimentation in the Cascade Range, central Washington, in v. 2 of Relaciones entre la tectonica $\mathbf{y}$ la sedimentacion: Internat. Geol. Cong., 20th, Mexico 1956, sec. 5, p. 439-453.

Bretz, J H., 1913, Glaciation of the Puget Sound region: Washington Geol. Survey Bull. 8, $244 \mathrm{p}$.

Broecker, W. S., and Kulp, J. L., 1957, Lamont natural radiocarbon measurements-[Pt.] 4: Science, v. 126, no. 3287, p. 1324-1334.
Brown, R. D., Jr., Gower, H. D., and Snavely, P.D., Jr., 1960, Geology of the Port Angeles-Lake Crescent area. Clallam County, Washington: U.S. Geol. Survey Oil and Gas Inv. Map OM-203 [1961].

Campbell, M. R., and others, 1915, Guidebook of the western United States, Pt. A, The Northern Pacific Route, with a side trip to Yellowstone Park: U.S. Geol. Survey Bull. 611, $212 \mathrm{p}$.

Chaney, R. W., 1938, Ancient forests of Oregon, A study of earth history in western America : Carnegie Inst. Washington Pub. 501, p. 631-648.

Coombs, H. A., 1936, The geology of Mount Rainier National Park: Washington Univ. [Seattle] Pub. Geology, v. 3, no. 2, p. 131-212.

1941, Hornblende and magnetite heavies in the Ellensburg of central Washington: Jour. Sed. Petrolo $\%$, v. 11, no. 3, p. 142-144.

Cooper, H. M., and Abernethy, R. F., 1941, Analysis of mine samples, in Analyses of Washington coals : U.S. Eur. Mines Tech. Paper 618, p. 33-47.

Crandell, D. R., 1957, Some features of mudfiow deposits [Washington] [abs.] : Geol. Soe. America Bull., v. 68, no. 12 , pt. 2, p. 1821.

1963, Surficial geology and geomorphology of the Lake Tapps quadrangle, Washington: U.S. Geol. Survey Prof. Paper 388-A, 84 p.

1965, The glacial history of western Washington and Oregon, in Wright, H. E., Jr., and Frey, D. G., eds., The Quaternary of the United States: Princeton Uriv. Press, p. 341-353.

Crandell, D. R., and Gard, L. M., Jr., 1959, Geolory of the Buckley quadrangle, Washington: U.S. Geol. Survey Geol. Quad. Map GQ-125.

Crandell, D. R., Mullineaux, D. R., and Waldron, H. H., 1958, Pleistocene sequence in southeastern part of the Puget Sound lowland, Washington: Am. Jour. Sci., v. 256, no. 6, p. 384-397.

1965, Age and origin of the Puget Sound trough in western Washington, in Geological Survey research 1965 : U.S. Geol. Survey Prof. Paper 525-B, p. B132-B136.

Crandell, D. R:, and Waldron, H. H., 1954, Recent rudfiow of exceptional dimensions from Mt. Rainier, Washington [abs.]: Geol. Soc. America Bull., จ. 65, no. 12, pt. 2, p. 1337.

-1956, A recent volcanic mudflow of exceptional dimensions from Mount Rainier, Washington: Am. Jour. Sci., v. 254 , no. 6, p. 349-362.

Dart, J. O., 1952, The changing hydrologic pattern of the Renton-Sumner lowland, Washington: Assoc. Pacific Coast Geographers Yearbook, v. 14, p. 19-23.

Durham, J. W., 1944, Megafaunal zones of the Oligocene of northwestern Washington: California Univ. Prbs. Geol. Sci., v. 27, no. 5, p. 101-211.

Easterbrook, D. J., 1963, Late Pleistocene glacial events and relative sea-level changes in the northern Puget Lowland, Washington: Geol. Soc. America Bull., v. 74, no. 12, p. 1465-1483.

Easterbrook, D. J., Crandell, D. R., and Leopold, E. B., 1967, Pre-Olympia Pleistocene stratigraphy and chrcnology in the central Puget Lowland, Washington: Geol. soc. America Bull., v. 78 , no. 1, p. 13-20. 
Ecke], E. B., ed., 1958, Landslides and engineering practice: Natl. Acad. Sci.-Natl. Research Council Highway Research Board Spec. Rept. 29, 232 p.

Evans, G. W., 1912, The coal fields of King County: Washington Geol. Survey Bull. 3, 247 p.

Fenneman, N. M., 1906, Floodplains produced without floods: Am. Geog. Soc. Bull., v. 38, p. 89-91.

Fisher, R. V., 1961, Stratigraphy of the Ashford area, southern Cascades, Washington: Geol. Soc. America Bull., v. 72, no. 9, p. 1395-1407.

Fiske, R. S., Hopson, C. A., and Waters, A. C., 1963, Geology of Mount Rainier National Park, Washington: U.S. Geol. Survey Prof. Paper 444, 93 p. [1964].

Flint, R. F., 1957, Glacial and Pleistocene geology: New York, John Wiley \& Sons, Inc., 553 p.

Folk, R. L., and Ward, W. C., 1957, Brazos River bar [Texas] - a study in the significance of grain size parameters: Jour. Sed. Petrology, v. 27, no. 1, p. 3-26.

Frye, J. C., and Willman, H. B., 1960, Classification of the Wisconsinan Stage in the Lake Michigan glacial lobe: Illinois Geol. Survey Circ. 285, 16 p.

Gard, L. M., Jr., 1960, Suggested source of Miocene volcanic detritus flanking the central Cascade Range, Washington, in Short papers in the Geological sciences: U.S. Geol. Survey Prof. Paper 400-B, p. B306-B307.

1968, Bedrock geology of the Lake Tapps quadrangle, Pierce County, Washington: U.S. Geol. Survey Prof. Paper 388-B, 33 p.

Geer, M. R., 1941, Description of mine samples, in Analyses of Washington coals: U.S. Bur. Mines Tech. Paper 618, p. 48-78.

Glover, S. L., 1936, Hammer Bluff formation of western Washington [abs.]: Pam-Am. Geologist, v. 65, no. 1, p. 77-78.

1941, Clays and shales of Washington: Washington Div. Mines and Geology Bull. 24, 368 p.

Gould, H. R., and Budinger, T. F., 1958, Control of sedimentation and bottom configuration by convection currents, Lake Washington, Washington: Jour. Marine Research, v. 17, p. 183-198.

Gower, H. D., and Wanek, A. A., 1963, Preliminary geologic map of the Cumberland quadrangle, King County, Washington: Washington Div. Mines and Geology Geol. Map GM-2.

Hansen, H. P., 1941, Further pollen studies of post Pleistocene bogs in the Puget lowland of Washington: Torrey Bot. Club Bull., v. 68, no. 3, p. 133-147.

1947, Postglacial forest succession, climate, and chronology in the Pacific Northwest: Am. Philos. Soc. Trans., v. 37, pt. 1, 130 p.

Hansen, H. P., and Mackin, J. H., 1949, A pre-Wisconsin forest succession in the Puget Lowland, Washington: Am. Jour. Sci., v. 247 , no. 12 , p. $833-855$.

Happ, S. C., Rittenhouse, Gordon, and Dobson, G. C., 1940, Some principles of accelerated stream and valley sedimentation: U.S. Dept. Agriculture Tech. Bull. 695, 134 p.

Jahns, R. H., 1947, Geologic features of the Connecticut Valley, Massachusetts, as related to recent floods: U.S. Geol. Survey Water-Supply Paper 996, 158 p.

Kimball, J. P., 1897, Physiographic geology of the Puget Sound basin : Am. Geologist, v. 19, p. 225-237, 304-322.
Kleinpell, R. M., 1938, Miocene stratigraphy of California: Am. Assoc. Petroleum Geologists, $450 \mathrm{p}$.

Landes, Henry, 1902, The coal deposits of Washington: Washington State Geologist's Ann. Rept. 1, pt. 4, p. 257-281.

Laval, W. N., 1956, Stratigraphy and structural geology of portions of south-central Washington: Washington Univ., unpub. Ph. D. thesis.

LeConte, J. L., 1874, On the great lava flood of the Northwert; and on the structure and age of the Cascade Mountains: Am. Jour. Sei., ser. 3, v. 7, p. 167-180, 259-267.

Liesch, B. A., Price, C. E., and Walters, K. C., 1963, Geology and ground water resources of northwestern King County, Washington: Washington Div. Water Resources Water Supply Bull. 20, 241 p.

Livingston, V. E., Jr., 1958, Oil and gas exploration in Washington, 1900-1957: Washington Div. Mines and Geology Inf. Cir. 29, $61 \mathrm{p}$.

Luzier, J. E., 1969, Geology and ground-water resources of southwestern King County, Washington: Washington Dent. Water Resources Water-Supply Bull. 28, 260 p.

Mackin, J. H., 1937, Erosional history of the Big Horn Barin, Wyoming: Geol. Soc. America Bull., v. 48, no. 6, p. 813893.

1938, Eastern margin of the Puget glacial lobe [abs.] : Geol. Soc. America Proc. 1937, p. 248.

1941, Glacial geology of the Snoqualmie-Cedar area,

Washington: Jour. Geology, v. 49, no. 5, p. 449-481.

1948, Concept of the graded river: Geol. Soc. America Bull., v. 59, no. 5, p. 463-511.

1956, Cause of braiding by a graded river [Idaho] [abs.] : Geol. Soc. America Bull., v. 67, no. 12, pt. 2, p. 1717-1718.

Mackin, J. H., and Cary, A. S., 1965, Origin of Cascade landscapes: Washington Div. Mines and Geology Inf. Circ. 41, $35 \mathrm{p}$.

McLellan, R. D., 1927, The geology of the San Juan Islanis: Washington Univ. [Seattle] Pub. Geology, v. 2, 185 p.

McLerran, J. H., and Krashevski, S. H., 1954, State of Washington Engineering Soils Manual, Pt. 3, Soils of King County: Washington State Council Highway Research, $107 \mathrm{p}$.

Mallory, V. S., 1959, Lower Tertiary biostratigraphy of the California Coast Ranges: Am. Assoc. Petroleum Geologi`ts, $416 \mathrm{p}$.

Moen, W. S., 1967, Building stone of Washington: Washington Div. Mines and Geology Bull. 55, 85 p.

Mullineaux, D. R., 1961, Geology of the Renton, Auburn, and Black Diamond quadrangles, Washington : U.S. Geol. S'trvey open-file report, $202 \mathrm{p}$.

1965a, Geologic map of the Renton quadrangle, King County, Washington: U.S. Geol. Survey Geol. Quad. Irap GQ-405.

1965b, Geologic map of the Auburn quadrangle, King and Pierce Counties, Washington: U.S. Geol. Survey Geol. Quad. Map GQ-406.

1965c, Geologic map of the Black Diamond quadrangle, King County, Washington: U.S. Geol. Survey Geol. Quad. Map GQ-407.

1967, Gross composition of Pleistocene clays in $S$ attle, Washington, in Geological Survey research 1967: T.S. Geol. Survey Prof. Paper 575-B, p. B69-B76. 
Mullineaux, D. R., Crandell, D. R., and Waldron, H. H., 1957, Multiple glaciation in the Puget Sound basin, Washington [abs.]: Geol. Soc. America Bull., v. 68, no. 12, pt. 2, p. 1772.

Mullineaux, D. R., Gard, L. M., Jr., and Crandell, D. R., 1959, Continental sediments of Miocene age in Puget Sound lowland, Washington: Am. Assoc. Petroleum Geologists Bull., v. 43, no. 3, p. 688-696.

Mullineaux, D. R., Nichols, T. C., and Speirer, R. A., 1964, A zone of montmorillonitic weathered clay in Pleistocene deposits at Seattle, Washington, in Geological Survey research 1964: U.S. Geol. Survey Prof. Paper 501-D, p. D99-D103 [1965].

Mullineaux, D. R., Waldron, H. H., and Rubin, Meyer, 1965, Stratigraphy and chronology of late interglacial and early Vashon glacial time in the Seattle area, Washington: U.S. Geol. Survey Bull. 1194-O, 10 p.

Newcomb, R. C., 1952, Ground-water resources of Snohomish County, Washington: U.S. Geol. Survey Water-Supply Paper 1135, 133 p. [1953].

Nichols, R. L., 1946, Preliminary report on King County, Washington, high-alumina clay deposits : U.S. Geol. Survey openfile report, $41 \mathrm{p}$.

Pettijohn, F. J., 1957, Sedimentary rocks [2d ed.] : New York, Harper \& Brothers, 718 p.

Poulson, E. N., Miller, J. T., Fowler, R. H., and Flannery, R. D., 1952, Soil survey of King County, Washington: U.S. Soil Conserv. Service Soil Survey Rept., ser. 1938, no. 31, 106 p.

Powers, H. A., and Wilcox, R. E., 1964, Volcanic ash from Mount Mazama (Crater Lake) and from Glacier Peak: Science, v. 144, no. 3624, p. 1334-1336.

Rau, W. W., 1958, Stratigraphy and foraminiferal zonation in some of the Tertiary rocks of southwestern Washington: U.S. Geol. Survey Oil and Gas Inv. Chart OC-57.

1966, Stratigraphy and Foraminifera of the Satsop River area, southern Olympic Peninsula, Washington: Washington Div. Mines and Geology Bull. 53, $66 \mathrm{p}$.

Rigg, G. B., 1958, Peat resources of Washington: Washington Div. Mines and Geology Bull. 44, 272 p.

Rigg, G. B., and Gould, H. R., 1957, Age of Glacier Peak eruption and chronology of post-glacial peat deposits in Washington and surrounding areas: Am. Jour. Sci., v. 255, no. 5, p. 341-363.

Rittmann, Alfred, 1952, Nomenclature of volcanic rocks proposed for the use in the catalogue of volcanoes, and keytables for the determination of volcanic rocks: Bull. Volcanol., ser. 2. v. 12, p. 75-102.

Roberts, A. E., 1958, Geology and coal resources of the ToledoCastle Rock district, Cowlitz and Lewis Counties, Washington: U.S. Geol. Survey Bull. 1062, 71 p.

Rubin, Meyer, and Alexander, Corrinne, 1958, U.S. Geological Survey radioearbon dates, [Pt.] 4: Science, v. 127, no. 3313 , p. $1476-1487$.

1960, U.S. Geological Survey radiocarbon dates, [Pt.] 5 : Am. Jour. Sci. Radiocarbon Supp., v. 2, p. 129-185.

Russell, I. C., 1898, Glaciers of Mount Rainier, with a paper on the rocks of Mount Rainier, by G. O. Smith: U.S. Geol. Survey 18th Ann. Rept., pt. 2, p. 349-423.

Sceva, J. E., 1957, Geology and ground-water resources of Kitsap County, Washington: U.S. Geol. Survey WaterSupply Paper 1413, 178 p.
Schenck, H. G., and Kleinpell, R. M., 1936, Refugian stage of Pacific coast Tertiary: Am. Assoc. Petroleum Geologists Bull., v. 20, no. 2, p. 215-225.

Sharpe, C. F. S., 1938, Landslides and related pheromena; a study of mass-movements of soil and rock: Naw York, Columbia Univ. Press, 136 p.

Smith, G. O., 1902, The coal flelds of the Pacific C.ast: U.S. Geol. Survey 22d Ann. Rept., pt. 3, p. 479-513.

1903, Description of the Ellensburg auadrangle [Washington]: U.S. Geol. Survey Geol. Atlas, Folio 86, $7 \mathrm{p}$.

Snavely, P. D., Jr., Brown, R. D., Jr., Roberts, A. E.. and Rau, W. W., 1958, Geology and coal resources of the CentraliaChehalis district, Washington, with a section on Microscopical character of the Centralia-Chehalis coal, by J. M. Schopf: U.S. Geol. Survey Bull. 1053, 159 p.

Snavely, P. D., Jr., and Wagner, H. C., 1963, Tertiary geologic history of western Oregon and Washington: V'ashington Div. Mines and Geology Rept. Inv. 22, $25 \mathrm{p}$.

Stokes, W. L., and Varnes, D. J., 1955, Glossary of selected geologic terms with special reference to their use in engineering: Colorado Sci. Soc. Proc., v. 16, 165 p.

Straub, L. G., 1942, Mechanics of rivers, in Meinzer, O. E., ed., Physics of the earth, Pt. 9. Hydrology: New York, McGraw-Hill Book Co., p. 614-636.

Theobald, P. K., Jr., 1957, The gold pan as a quantitative geologic tool : U.S. Geol. Survey Bull. 1071-A, p. 1-54.

Thorsen, G. W., 1961, Directory of Washington miring operations 1960: Washington Div. Mines and Geology Inf. Circ. $35,84 \mathrm{p}$.

Trask, P. D., 1932, Origin and environment of source sediments of petroleum: Am. Petroleum Inst., $323 \mathrm{p}$.

U.S. Army Corps of Engineers, 1953, The Unified Soil Classification System: U.S. Army Corps of Engin`ers Tech. Memo. 3-357, v. 1-3.

U.S. Weather Bureau, 1961, Climatic guide for Seattle, Washington and adjacent Puget Sound area : $48 \mathrm{p}$.

Valentine, G. M., 1949, Inventory of Washington minerals, Pt. 1, Nonmetallic minerals: Washington Div. Mines and Geology Bull. 37, 113 p.

Varnes, D. J., 1958, Landslide types and processes, Chap. 3 of Eckel, E. B., ed., Landslides and engineering practice: Natl. Acad. Sci.-Natl. Research Council Highway Research Board spec. Rept. 29, p. 20-47.

Vine, J. D., 1962a, Stratigraphy of Eocene rocks ir a part of King County, Washington: Washington Div. Mines and Geology Rept. Inv. 21, 20 p.

$1962 \mathrm{~b}$, Preliminary geologic map of the Hobart and Maple Valley quadrangles, King County, Washington: Washington Div. Mines and Geology Geol. Map GM-1.

Vine, J. D., 1969, Geology and coal resources of tl ? Cumberland, Hobart, and Maple Valley quadrangles, Kìng County, Washington: U.S. Geol. Survey Prof. Paper 624, 67 p. [1970].

Waldron, H. H., 1961, Geology of the Poverty Bay quadrangle, Washington: U.S. Geol. Survey Geol. Quad. Map GQ-158. 1962, Geology of the Des Moines quadrargle, Washington: U.S. Geol. Survey Geol. Quad. Map GQ-159.

1967, Geologic map of the Duwamish Head quadrangle, King and Kitsap Counties, Washington: U.S. Geol. Survey Geol. Quad. Map GQ-706. 
Waldron, H. H., Liesch, B. A., Mullineaux, D. R., and Crandell, D. R., 1962, Preliminary geologic map of Seattle and vicinity, Washington: U.S. Geol. Survey Misc. Geol. Inv. Map I-354.

Waldron, H. H., Mullineaux, D. R., and Crandell, D. R., 1957, Age of the Vashon glaciation in the southern and central parts of the Puget Sound basin, Washington [abs.]: Geol. Soc. America Bull., v. 68, no. 12, pt. 2, p. 1849-1850.

Walters, K. L., 1965, Mashel Formation of southwestern Pierce County, Washington, in Cohee, G. V., and West, W. S., Changes in stratigraphic nomenclature by the U.S. Geological Survey 1964: U.S. Geol. Survey Bull. 1224-A, p. A55-A59.

Warren, W. C., Norbisrath, Hans, Grivetti, R. M., and Brown, S. P., 1945, Preliminary geologic map and brief description of the coal fields of King County, Washington: U.S. Geol. Survey Coal Inv. Map.

Weaver, C. E., 1912, A preliminary report on the Tertiary paleentology of western Washington: Washington Geol. Survey Bull. 15, $80 \mathrm{p}$.

1916, The Tertiary formations of western Washing-

ton: Washington Geol. Survey Bull. 13, 327 p. 1937, Tertiary stratigraphy of western Washington and northwestern Oregon: Washington Univ. [Seattle] Pub. Geology, v. 4, 266 p.

1942, Paleontology of the marine Tertiary formations of Oregon and Washington: Washington Univ. [Seattle] Pub. Geology, v. 5, pts. 1-3, 789 p.

1945, Geology of Oregon and Washington and its relation to occurrence of oil and gas: Am. Assoc. Petroleum Geologists Bull., v. 29, no. 10, p. 1377-1415.

Weaver, C. E., and others, 1944, Correlation of marine Cenozoic formations of western North America [chart 11]: Geol. Soc. America Bull., v. 55, no. 5, p. 569-598.
White, C. A., 1888, On the Puget group of Washington Territory: Am. Jour. Sci., v. 36, p. 443-450.

1889, On invertebrate fossils from the Pacific coast: U.S. Geol. Survey Bull. 51, 102 p.

Williams, Howel, Turner, F. J., and Gilbert, C. M., 1954, Petrography-an introduction to the study of rocks in tr in sections: San Francisco, W. H. Freeman and Co., 406 p.

Willis, Bailey, 1886, Report on the coal fields of Washington Territory: U.S. 10th Census, v. 15, p. 759-771. 1898a, Some coal fields of Puget Sound: U.S. Geol. Survey 18th Ann. Rept., pt. 3, p. 393-436.

1898b, Stratigraphy and structure of the Puget growp, Washington: Geol. Soc. America Bull., v. 9, p. 2-6. 1898c, Drift phenomena of Puget Sound: Geol. Sxc. America Bull., v. 9, p. 111-162.

Willis, Bailey, and Smith, G. O., 1899, Description of the racoma quadrangle [Washington]: U.S. Geot. Survey Geol. Altas, Folio 54, 10 p.

Wilson, S. D., and Johnson, K. A., 1964, Slides in over-consolidated clays along the Seattle Freeway, in $2 d$ Ann. E Geology and Soils Eng. Symposium Proc., Pocatello, Idaho, 1964: p. 29-43.

Wolfe, J. A., 1968, Paleogene biostratigraphy of nonmarine rocks in King County, Washington: U.S. Geol. Surrey Prof. Paper 571, $33 \mathrm{p}$.

Wolfe, J. A., Gower, H. D., and Vine, J. D., 1961, Age and correlation of the Puget group, King County, Washington, in Short papers in the geologic and hydrologic sciences: U.S. Geol. Survey Prof. Paper 424C, p. C230-C232.

Wolman, M. G., and Leopold, L. B., 1957, River fiood plains; Some observations on their formation: U.S. Geol. Survey Prof. Paper 282-C, p. 87-109. 



\section{INDEX}

[Italic page numbers indicate major references]

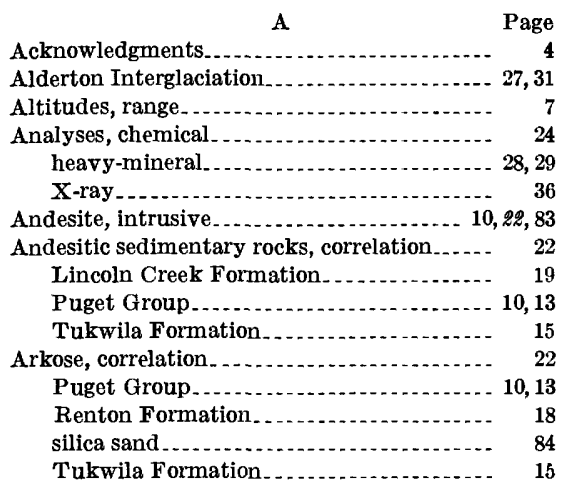

B

Bayne Series, Puget Group.

Bedrock, previous studies .

Big Soos Creek .................. 8,57

Black Diamond anticline................... 11,71

Black River

Blackmon, P. D., analyst...........

Brown, R. W., fossil identification ............ 26

\section{C}

Carbonado Formation

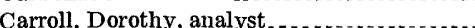

Cedar River, diversions...................... 63

Cedar River fanl............................ 59

Cedar River valley, alluvium, lithology ...... 57 alluvium, thickness .................... 57 drainage.................................. 64

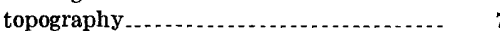

Cedar Spillway ............................. 65

Cedar Spillway of Mackin _................... $\quad 47$

Central Cascade detrital material ............... 27

Channel deposits.......................... 68

Chemical analysis, andesite................. 24

Chloe, Gillison, analyst..................... 36

Chlorite

Clay, refractory ...............................

Clay-mineral content, Hammer Bluff Formation...

intermediate drift.

Lincoln Creek Formation

Orting Drift.

Puget Group

Renton Formation

Tukwila Formation

16

Vashon Drift till

Climate, Pleistocene

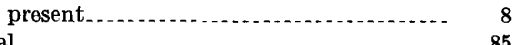

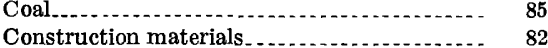

Construction materials ......................
Covington bog

Covington channel ..................... 7, 47, 48, 65

D

Delta, at Auburn $\ldots . . . . . . . . . . . . . . . . . .49$ Drainage .............................. 6,9,68,78 effects of postglacial changes.............. 65

historic changes

\section{Page}

Drift plain, relief...

7,45

Duwamish Valley, alluvium, dating

alluvium, lithology of fans.

thickness.

definition

drainage

origin

topography

Economic geology

clay -

coal. -

oil and gas.

peat and topsoil

silica sand.

Engineering geology

construction materials

engineering properties of deposits. .......

ground water.

landslides..................................

overconsolidation problems

till, heterogeneity

Excavation properties. .

\section{F}

Faults

(auls

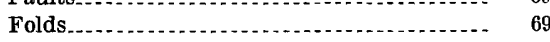

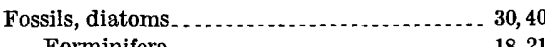

Forminifera . . . . . .

plants. ............................... 14, 17, 21, 26

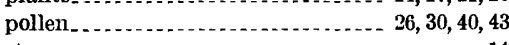

stages.

Foundation stability . . .

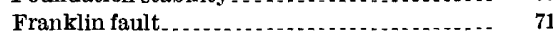

Franklin Series, Puget Group..........

Fraser Glaciation

\section{G}

Garnet.

(1)

Pleistocene deposits .....................

Puget Group.

Renton Formation

Vashon Drift till

Geologic history.-

Geologic quadrangle maps

Geomorphology -

fiood-plain developnen

river characteristies. . . . . .

Glacier ice, thickness.

Grain size, arkose...

channel gravel

Green River, diversions......... streamiflow

Green River valley, alluvium, channel material .....................

alluvium, fiood-plain material . . ........... thickness............................... drainage......................................

topography

Ground moraine.

Ground water
$\mathbf{H}$

Fage

Hammer Bluff Formation

Hathaway, J. C., analyst

Heavy-mineral content, Cedar River valley alluvium.

Green River valley alluvium

Hammer Bluff Formation

modern alluvium.

Pleistocene deposits

Puget Group.

.

Hormblende, as characteristic mineral . . . . 25, 26, 28

Hypersthene, as characteristic mineral . . . 28, 56, 59

I

Intermediate drift....................... 35

Intrusive rocks, location and analysis......... 22

Israelsky, M. C., fossil Foraminifera identification

$\mathbf{K}$

Kaolinite, as characteristic mineral. ........ 16 Kummer fint clay . . . . . . .

Kummer Series, Puget Group.............. 10,11 Kummer syncline................. 11

L

Land use, geologic influence on............. $\quad 77$

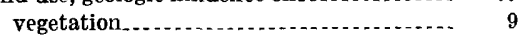

Landslides, causes ........................ 54, 82 recognition criteria . . . . . . . . . . . . . . . . .. 53, 82 types..

See also Engineering geology, landslides.

Leopold, E. B., fossil identification . .... 26, 30, 40, 43 Lincoln Creek Formation . . . . . . . . . . . . ..... 19

Location of area............................. 3

Lohman, K. E., fossil diatom identification . . 30,40

Lower Tertiary rocks..................... 10 correlation . . . . structure

M

MeNeil, F. S., fossil identifications .......... 14 Marine till................................. 39 Melt-water rivers. ...................... 46, 47, 48, 65 Montmorillonite, as characteristic mineral _. 24,32, 56 Moore, E. J., fossil iden tification.......... 21, 61 Mount Rainier detrital material. ............ $\quad 27$

\section{$N$}

Newaukum Creek......................... 8,57 Newcastle Hills promontory $\ldots \ldots \ldots$ Nonglacial sediments............... Northeraft Formation............... 22 Northern Cascade detrital material.......... $\quad 27$ O

Ohanapecosh Formation . Olympia Interglaciation $\ldots \ldots \ldots \ldots . .27,31,62$ 22 Orting Drift. Osceola Mudfiow 


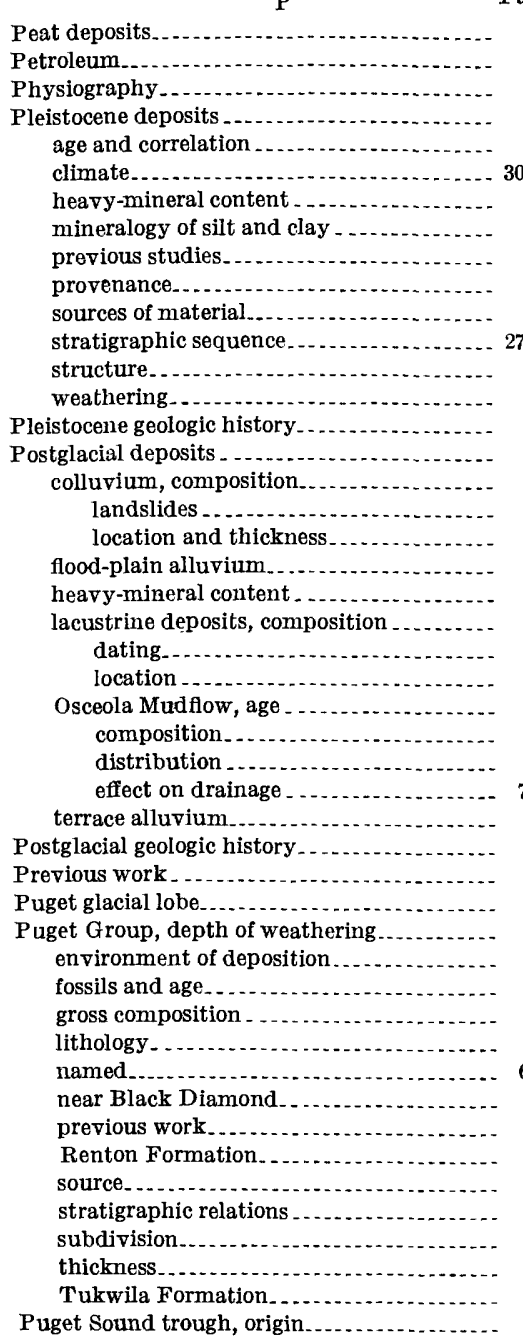

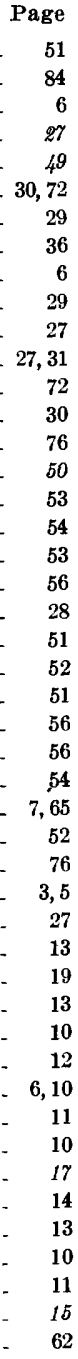

Page

Pumice . . . . . . . . . . .

Purpose and scope .......................... 3

Puyallup Formation

\section{$\mathbf{R}$}

Rau, W. W., fossil Foraminifera identification

References cited.............................. 86

Renton anticline ........................ 69

Renton Formation

Renton Formation $\ldots$

River gradients............................... 66

River overbank deposits.................. 68

Roslyn Formation

Rubin, Meyer, radiocarbon analyses.........

Salmon Springs Drift_..................... 41 Sand and gravel.

Schlocker, Julius, analyst .

Siderite

Slope stability

South Prairie Creek

Springbrook syncline.

71

Starkey, H. C., analyst . . . . . . . . . . . . . . . 28, 29, 36

Steele Crossing locality ................... 17

Stone ......................... 83

Streamflow measurements

Structure

Stuck Glaciation.

Sunbeam fault........................... 71

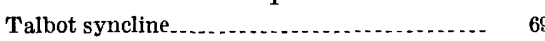

Taylor, D. W., mollusk identification $\ldots$

Tertiary geologic history .................... 75

Tertiary rocks..............................

Tiger Mountain area.................... 17, 19, 22

Tiger Mountain Formation ............... 10, 16, 22

Till deposits, ablation .................. 45

engineering properties . ................... 80

lodgment

mineralog $\mathrm{v}$ of silt and clay fractions ..... $\quad 36$

particle-size distribution................. 35

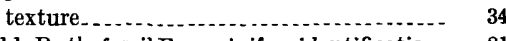

$\begin{array}{ll}\text { Todd, Ruth, fossil Foraminifera identification. } & 21 \\ \text { Troughs, geomorphic, origin.................. } & 62\end{array}$
Page

Tuff.

Tukwila anticline.

Tukwila Formation .

U

Unconformity, Hammer Bluff Formation ... intermediate drift

Lincoln Creek

dermation.................

Renton Formation.

Salmon Springs Drift.

Sifferentiated drift

(n)

Upper Tertiary rocks, structure.............. 72 See also Hammer Bluff Formation.

$\mathrm{V}$

Vashon Drift.............................. 49,80

Vashon glacier, effects on drainage........... 64

Vegetation, relation to geologic deposits ....... 9

Volcanic ash ............................... 25, 39

Mazama layer $\ldots \ldots . .51,61$

Volcanic mudflows................. $16,26,39,54,68$

Volcanic rocks, history.

See also Tukwila Formation.

\section{W}

Weathering, Hammer Bluff Formation ....... 25,84 intermediate drift. .................... 38

Orting Drift............................ 32

Pleistocene deposits .................... $\quad 30$

Puget Group

Puyallup Formation. . .

Tukwila Formation.................. 16

White River, diversions. ................... 63 streamflow .............................. 66

White River fan............................. 60

White River valley, alluvium, litholopy and source...................... 59 alluvium, thickness.................... 58

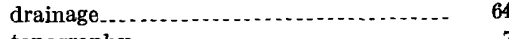
topography Willis, Bailey, quoted ...................... 43,44 Wolfe, J. A., fossil plant identification. ...... 17, 18

$$
\mathrm{Y}, \mathrm{Z}
$$

Yucca Formation. ....................... 36 Zircon, as characteristic mineral.......... 12 